$$
\text { Universidade de São Paulo }
$$

Faculdade de Medicina de Ribeirão Preto

Genes de hexamerinas em Apis mellifera: busca de funções alternativas durante o desenvolvimento

Juliana Ramos Martins

Ribeirão Preto, SP 


\title{
Genes de hexamerinas em Apis mellifera: busca de funções alternativas durante o desenvolvimento
}

\author{
Tese apresentada à Faculdade de \\ Medicina de Ribeirão Preto da \\ Universidade de São Paulo para \\ obtenção do título de Doutor em \\ Ciências.
}

Área de concentração: GENÉTICA

Orientadora: $\operatorname{Prof}^{\mathrm{a}} \mathrm{Dr}^{\mathrm{a}}$ Márcia Maria Gentile Bitondi

\section{Ribeirão Preto, SP}


Autorizo a reprodução ou divulgação total ou parcial deste trabalho, por qualquer meio convencional ou eletrônico, para fins de estudo ou pesquisa, desde que citada à fonte.

Martins, Juliana Ramos

Genes de hexamerinas em Apis mellifera: busca de funções alternativas durante o desenvolvimento. Ribeirão Preto, 2012.

189p.: Il.

Tese de Doutorado, apresentada á Faculdade de Medicina de Ribeirão Preto/USP. Área de concentração: Ciências Biológicas I, com ênfase em Genética.

Orientador(a): Bitondi, Márcia Maria Gentile.

1. Apis mellifera 2. Metamorfose 3. Hormônio juvenil 4. Ovário 5. Testículo 
Nome: MARTINS, Juliana Ramos

Título: Genes de hexamerinas em Apis mellifera: busca de funções alternativas durante o desenvolvimento

Tese apresentada à
Faculdade de Medicina de
Ribeirão Preto da
Universidade de São Paulo
para obtenção do título de
Doutor em Ciências

Aprovado em:

Banca examinadora

Prof(a). Dr(a).

Instituição:

Julgamento: Assinatura:

$\operatorname{Prof(a)} \cdot \operatorname{Dr}(a)$ : .Instituição:

Julgamento: Assinatura:

Prof(a). Dr(a): ..Instituição:

Julgamento:. Assinatura:

Prof(a). Dr(a): .Instituição:

Julgamento: Assinatura:

Prof(a). Dr(a): ..Instituição:

Julgamento: Assinatura: 


\section{Dedicatória}

Smile, though your heart is aching Smile, even though it's breaking When there are clouds in the sky You'll get by...

If you smile

With your fear and sorrow Smile and maybe tomorrow You'll find that life is still worthwhile if you'll just.

Light up your face with gladness

Hide every trace of sadness Although a tear may be ever so near That's the time you must keep on trying Smile, what's the use of crying?

You'll find that life is still worthwhile If you'll just Smile (Charles Chaplin)

Em memória de Janaína Ramos Martins e da Dra. Maria José de Fátima Bispo Pereira Okano, dedico! 


\section{Agradecimentos}

"A gratidão desbloqueia a abundância da vida. Ela torna o que temos em suficiente, a negação em aceitação, o caos em ordem, a confusão em claridade. Ela pode transformar uma refeição em um banquete, uma casa em um lar, um estranho em um amigo. A gratidão dá sentido ao nosso passado, o traz para o hoje, e cria uma visão para o amanhã" (Melody Beattie).

Agradeço à minha orientadora, Prof ${ }^{\mathrm{a}}$. Dr ${ }^{\mathrm{a}}$. Márcia Maria Gentile Bitondi, pela dedicação, apoio, confiança e estímulo. Por todos estes anos de aprendizado.

À Prof ${ }^{\mathrm{a}}$. Dr ${ }^{\mathrm{a}}$. Zilá Luz Paulino Simões, pela receptividade no laboratório.

Aos técnicos do Laboratório de Biologia do Desenvolvimento de Abelhas (LBDA), pelo suporte laboratorial e no Apiário. Á Nayara e ao seu Pedro, pela aquisição das rainhas ovipositoras. Ao Omar e ao David pelos zangões. Ao Doutor Rodrigo Pires Dallacqua, aos pós-graduandos André Fernando Ditondo Micas e Guaracini Aparecida Loterio, pela colaboração e amizade. A todas as pessoas que trabalham ou que trabalharam no LBDA (Departamento de Genética - FMRP-USP) durante a produção desta tese e que somaram para o meu crescimento como pesquisadora.

Ao Doutor Alexandre dos Santos Cristino (The Queensland Brain Institute, The University of Queensland, Brisbane, Queensland, Australia) pela colaboração com as análises de Bioinformática.

Ao técnico Paulinho, do Laboratório de Genética e Evolução (Departamento de Genética - FMRP-USP), por autoclavar o meu material.

À Prof ${ }^{\mathrm{a}}$. Dr ${ }^{\mathrm{a}}$. Aline Mackert dos Santos, do Departamento de Ciências do Ambiente da UFMS, pela colaboração nos experimentos de alimentação diferencial entre castas, pelo apoio e carinho.

Ao Doutor Lucas Anhezini Araújo, à Técnica Mara Silvia Alexandre e ao Prof. Ricardo Guelerman Pinheiro Ramos do Laboratório de Genética Molecular do Desenvolvimento (Departamento de Biologia Celular e Molecular e Bioagentes Patogênicos FMRP-USP), pela dedicação e colaboração com os experimentos de imunolocalização e microscopia confocal. Á Elizabete Rosa Milani, técnica da microscopia confocal.

Ao Prof. Dr. Marcelo Valle de Sousa, ao Prof. Dr. Carlos André Ornelas Ricart, ao técnico Nuno Manuel Domingues, aos pós-graduandos Diana Paola Gómez Mendoza, Humberto Gonczarwska Jorge, Jaques Miranda Ferreira de Souza e Rayner Myr Lauterjung 
Queiroz, do Laboratório de Bioquímica e Química de Proteínas (Departamento de Biologia Celular - Unb); pela colaboração nos ensaios de cromatografia e espectrometria de massa.

Ao doutorando Germano Aguiar Ferreira e à doutora Carolina Thiomé, do Laboratório de Química de Proteínas (Hemocentro de Ribeirão Preto), pela colaboração e auxílio com os experimentos de proteínas de membrana. Ao Prof. Dr. Pietro Ciancaglini e sua pós-graduanda Ana Maria Sper Simão (Departamento de Química - FFCLRP - USP) pela colaboração, inúmeros conselhos e consultorias.

À técnica Maria Dolores Seabra Ferreira (Tuca) e ao técnico José Augusto Maulin, do Laboratório de Microscopia Eletrônica (Departamento de Biologia Celular e Molecular e Bioagentes Patogênicos - FMRPUSP); ao Prof. Dr. Marcos Antônio Rossi e sua técnica Lígia Grecco V. B. Santoro (Patologia - FMRP - USP), pela colaboração na microscopia eletrônica.

Ao Prof. Dr. Luis Eduardo Soares Netto e sua técnica Simone Vidigal Alves (Instituto de Biociências da USP - Departamento de Genética e Biologia Evolutiva - Laboratório de Genética e Biologia Molecular de Oxidantes e Radicais Livres), pelo auxílio na expressão in vitro das hexamerinas.

Ao Departamento de Genética, ao qual pertenço como aluna de pós-graduação, em especial ao Prof. Dr. Espencer Egea Soares pela colaboração durante a minha estada em Brasília.

À FAPESP, pelo apoio financeiro.

Aos meus amigos de Ribeirão Preto e de Poços de Caldas pelo apoio e compreensão. À minha família (Marlene Ramos Martins, Rubens Antônio Martins, Rubens Antônio Martins Filho, Luma Martins Tramonte, Liz Martins Tramonte e Lavínia Martins) o meu eterno agradecimento. 


\section{Resumo}

Martins JR. Genes de hexamerinas em Apis mellifera: busca de funções alternativas durante o desenvolvimento. 2012. 189p. Tese de Doutorado - Departamento de Genética, Faculdade de Medicina de Ribeirão Preto, Universidade de São Paulo, Ribeirão Preto, 2012.

Introdução: Hexamerinas são proteínas de estocagem sintetizadas pelo corpo gorduroso de larvas de insetos e secretadas na hemolinfa, onde se acumulam. A função canônica das hexamerinas consiste em servir de reserva de aminoácidos e energia para a reconstrução de tecidos e órgãos durante a metamorfose. Este trabalho teve como objetivo a busca por evidências de funções alternativas das hexamerinas durante o ciclo de vida de abelhas $A$. mellifera.

Resultados: Os perfis temporais de expressão das quatro hexamerinas (HEX 70a, HEX 70b, HEX 70c e HEX 110), verificados por meio de SDS-PAGE e western blot, corroboram sua função canônica na metamorfose. Consistente com esta função, as quatro hexamerinas foram localizadas no citoplasma das células do corpo gorduroso utilizando-se anticorpos específicos e microscopia confocal. No entanto, funções adicionais puderam ser inferidas com base nos seguintes resultados: (1) Foci das quatro hexamerinas foram localizados nos núcleos de algumas células do corpo gorduroso em metamorfose, levando à hipótese de que têm função anti-apoptótica durante este período crítico do desenvolvimento; (2) Além disso, HEX 70a e HEX 110 foram localizadas no citoplasma e núcleo de células ovarianas e testiculares, indicando função no desenvolvimento e maturação das gônadas; (3) A co-localização de um análogo de timidina (EdU) e HEX 70a nos núcleos das células dos ovaríolos, sugeriu fortemente uma função na proliferação celular. O knockdown de HEX 70a in vivo por meio de injeção de anticorpo específico prejudicou o crescimento dos ovaríolos de rainhas, reforçando a hipótese de função na proliferação celular, (4) interferiu na esclerotização da cutícula de operárias, indicando função na formação do exoesqueleto e (5) provocou a antecipação da ecdise adulta, provavelmente em resposta à ausência (ou diminuição) dos aminoácidos derivados das hexamerinas. Foram investigados também aspectos da regulação dos genes de hexamerinas. A manipulação experimental da dieta alimentar e dos títulos do hormônio juvenil (HJ) interferiram claramente na expressão dos genes de hexamerinas. A potencial ação reguladora do HJ foi reforçada pelos resultados de análises por bioinformática da região 5' UTR de cada gene de hexamerina (Martins et al., 2010) que revelaram potencial motivo de ligação à proteína Ultraspiracle (Usp), um membro do complexo receptor do HJ no DNA. 
Procedimentos para expressar as hexamerinas in vitro em sistema de bactérias e purificá-las estão em progresso visando a caracterização da estrutura e de interações entre as subunidades.

Conclusão: Estes resultados ressaltam que as hexamerinas têm outras funções no ciclo de vida de A. mellifera, além da função já bem estabelecida de reserva de aminoácidos para a metamorfose.

Palavras-chave: Hexamerinas; Apis mellifera; Metamorfose; Hormônio juvenil; corpo gorduroso; testículo; ovário 


\begin{abstract}
Martins JR. Hexamerin genes in Apis mellifera: alternative functions during development. 2012. 189p. PhD thesis - Genetics Department, Faculdade de Medicina de Ribeirão Preto, Universidade de São Paulo, Ribeirão Preto, 2012.

Background: Insect hexamerins are storage proteins synthesized by the larval fat body and secreted into the hemolymph, where they accumulate. The canonical function of hexamerins is to provide amino acids and energy for the reconstruction of tissues and organs during pupal-to-adult development. The aim of the current study was to search for evidence of alternative roles for the hexamerins in the life cycle of the honey bee, A. mellifera.
\end{abstract}

Results: The canonical role of insect hexamerins received support from our data on the temporal expression profiles of the four honey bee hexamerin subunits (HEX 70a, HEX 70b, HEX 70c and HEX 110), as verified by SDS-PAGE and western blot using hemolymph and fat body samples. Consistent with the canonical function, the four hexamerins were localized in the cytoplasm of fat body cells, during metamorphosis, by using specific antibodies and confocal laser-scanning microscopy. However, additional functions could be inferred by the following findings: (1) The four hexamerins were also localized in the nuclei of some fat body cells, thus tentatively suggesting an anti-apoptotic role during metamorphosis; (2) Furthermore, HEX 70a and HEX 110 were localized in the cytoplasm and nucleus of ovarian and testicular cells, pointing to a role in gonad development and maturation. Co-labeling of the thymidine analog EdU and HEX 70a in the ovariole cell nuclei, strongly suggested a role in cell proliferation; HEX 70a depletion via injection of the specific antibody in queen pupae impaired ovariole growth, thus strengthening our hypothesis on a role in cell proliferation, (3) HEX 70a depletion also impaired cuticle sclerotization, indicating a function in exoskeleton formation, and (4) led to a precocious adult ecdysis, perhaps in response to the lack (or decrease) in hexamerin-derived amino acids. We also investigated aspects of the regulation of hexamerin genes. The experimental manipulation of diet consumption and juvenile hormone (JH) titer clearly interfered in the expression of hexamerin genes. Regulation by $\mathrm{JH}$ was also supported by a previous bioinformatics analysis of the 5' UTR region of each hexamerin gene (Martins et al., 2010), which revealed a potential binding site for Ultraspiracle (Usp), a member of the $\mathrm{JH}$ receptor complex in the DNA. Experiments are in progress for in vitro expression and purification of the four hexamerins aiming to further characterize their structures and interactions. 
Conclusion: Taken together, these results imply in novel roles for hexamerins in the life cycle of A. mellifera in addition to their well-established role as amino acids sources for metamorphosis.

Keywords: Hexamerins; Apis mellifera; Metamorphosis; Juvenile hormone; fat body; testicle; ovaries 


\section{Lista de Figuras}

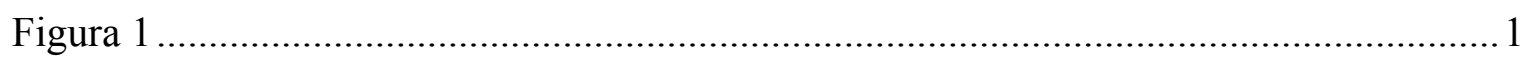

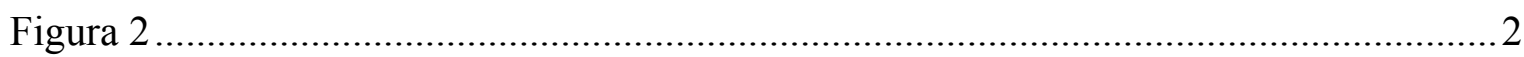

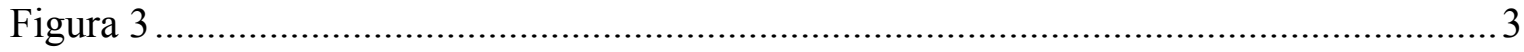

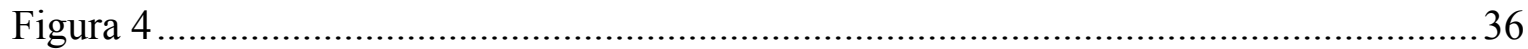

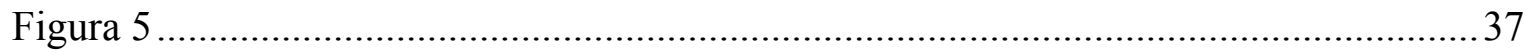

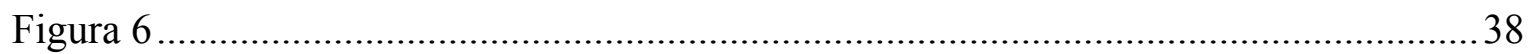

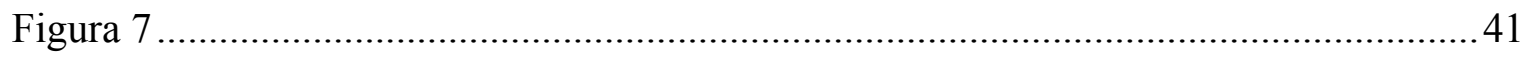

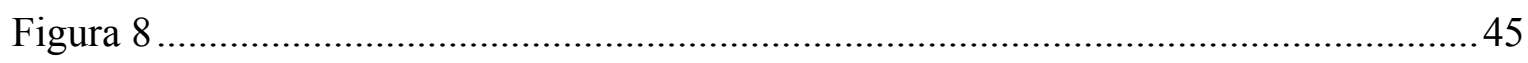

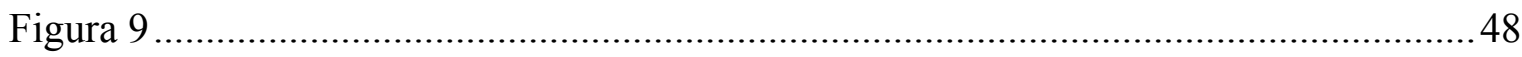

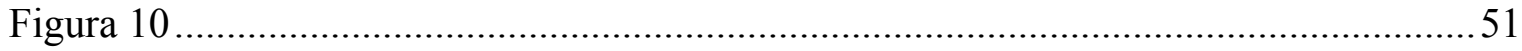

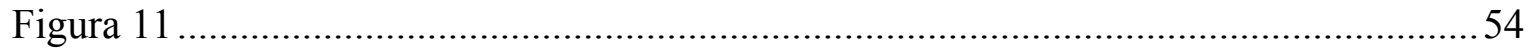

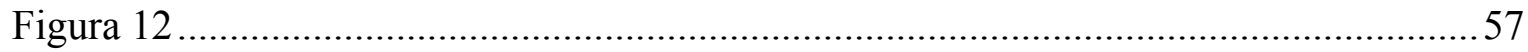

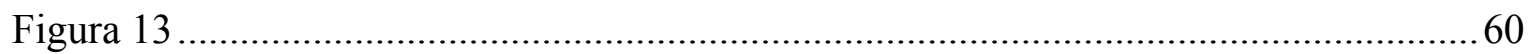

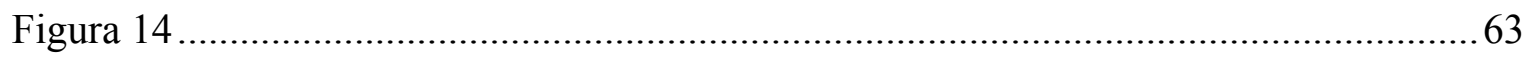

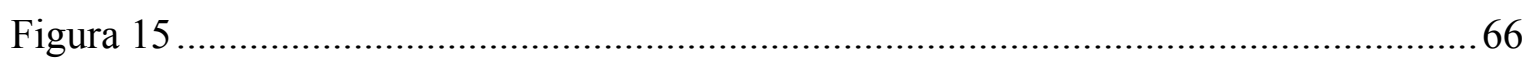

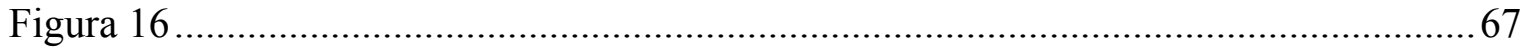

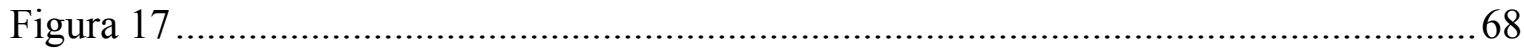

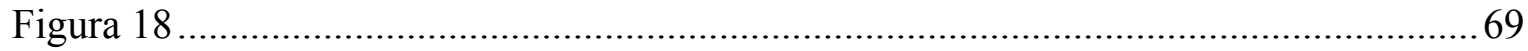

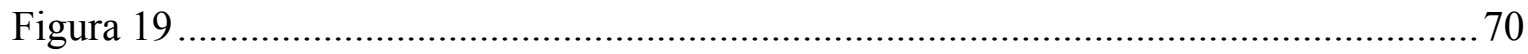

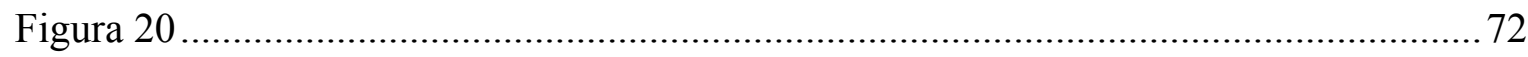

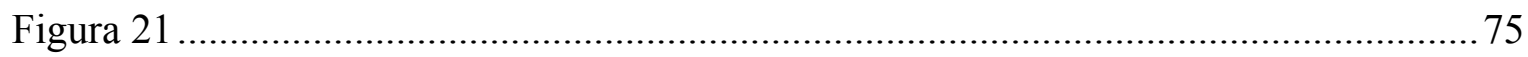

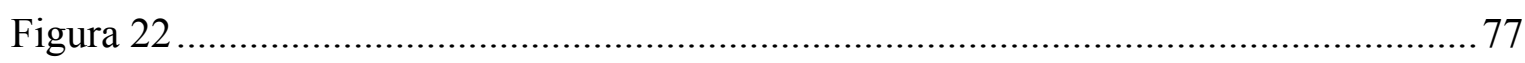

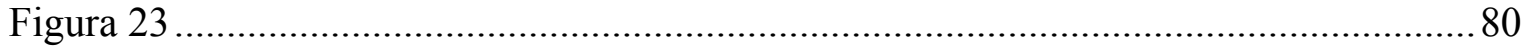

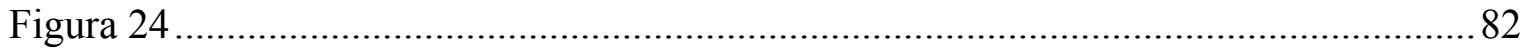

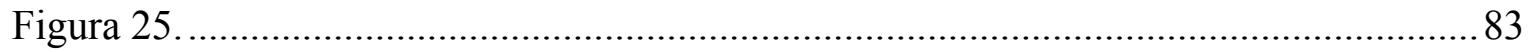

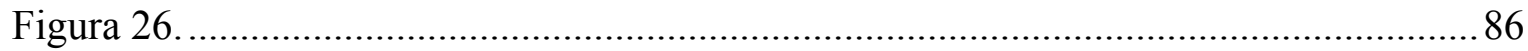

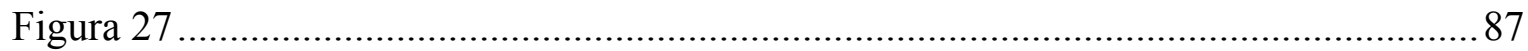

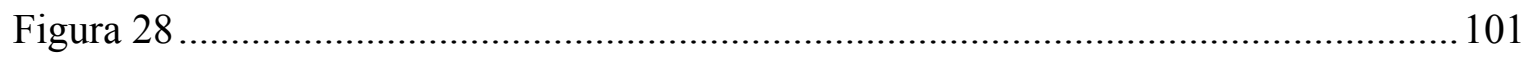

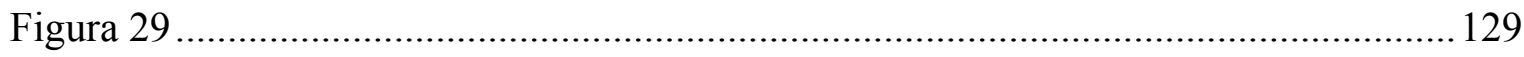

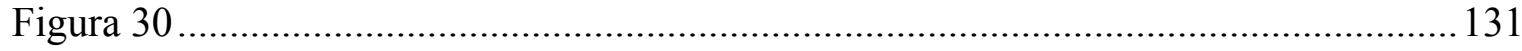

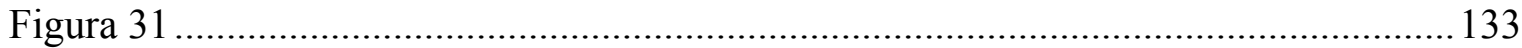

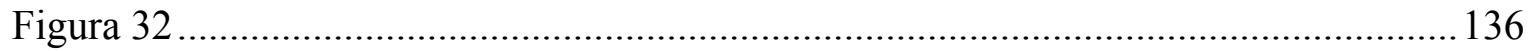




\section{Lista de Tabelas}

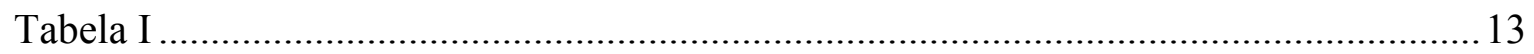

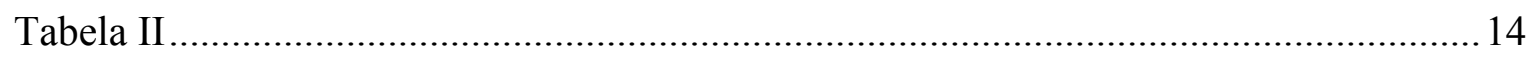

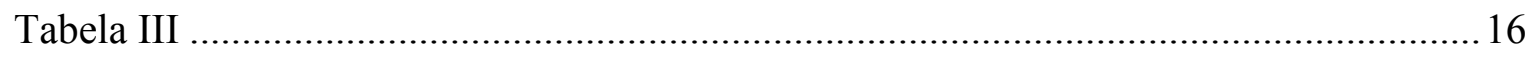

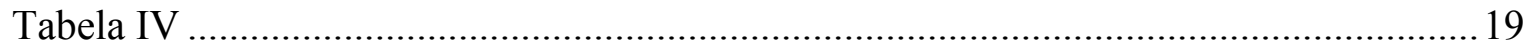

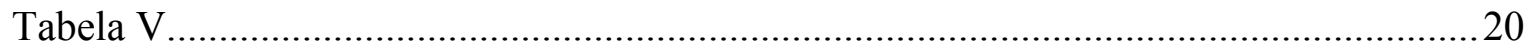

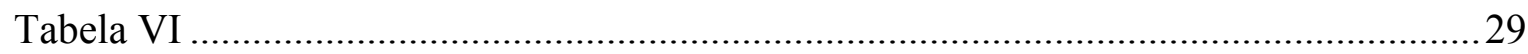

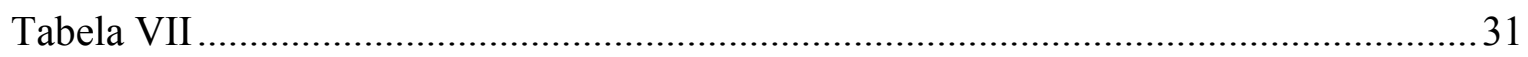

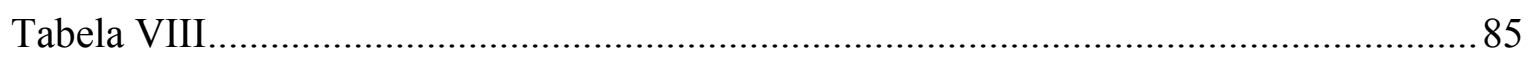




\section{Lista de abreviaturas e símbolos}

$\mathrm{kDa}=$ kiloDalton

$\mu \mathrm{L}=$ microlitro

$\mu \mathrm{g}=$ micrograma

$\mathrm{m}=$ metro

$\mathrm{Kg}=$ kilograma

$\mathrm{mL}=$ mililitro

$\mathrm{RPM}=$ rotações por minuto

$\mathrm{mM}=$ milimolar

$\mathrm{M}=$ molar

$\mathrm{pb}=$ pares de bases

$\mathrm{U}=$ unidades

$\mathrm{V}=$ volt

Min $=$ minuto

X $g=$ rotação por força centrífuga

$\mathrm{RT}-\mathrm{PCR}=$ reverse transcription polymerase chain reaction

$\mathrm{RT}-\mathrm{qPCR}=$ quantitative reverse transcription polymerase chain reaction

DAPI = 4,6-diamidino-2-phenylindole

$\mathrm{DEPC}=$ diethylpyrocarbonate

$\mathrm{PBS}=$ phosphate buffered saline

$\mathrm{BSA}=$ bovine serum albumin

SDS-PAGE = sodium dodecyl sulfate polyacrylamide gel elestrophoresis $\mathrm{mA}=$ miliamper

$\mathrm{FPLC}=$ fast protein liquid chromatography

TFA = trifluoroacetic acid

$\mathrm{v} / \mathrm{v}=$ volume/volume

$\mathrm{s}=$ segundo

DO $=$ densidade ótica

$\mathrm{UTR}=$ untranslated region

HEX $=$ subunidade proteica de hexamerina

hex $=$ gene de hexamerina 


\section{Sumário}

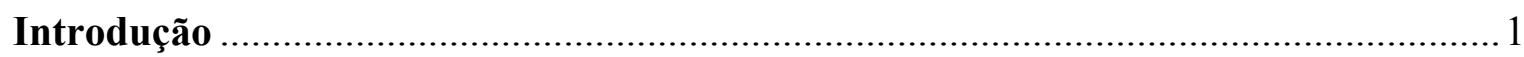

1. Aspectos da biologia de Apis mellifera ….................................................................. 1

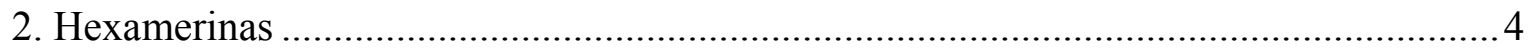

3. Histórico do estudo de hexamerinas em Apis mellifera ................................................6

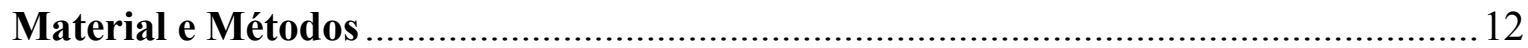

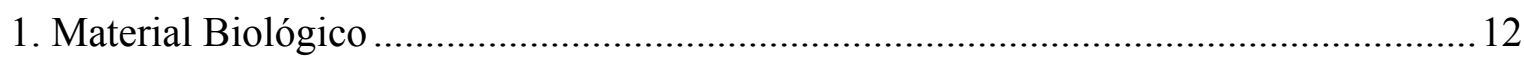

1.1. Operárias e rainhas em diferentes estágios e fases da ontogênese ............................. 12

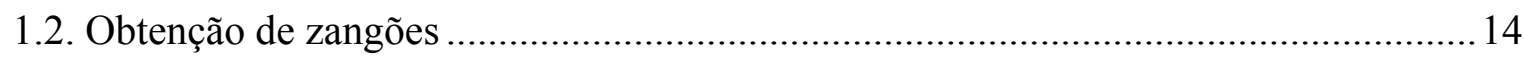

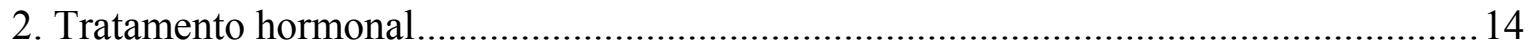

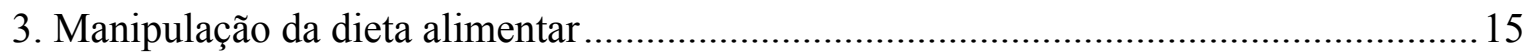

3.1. Alternância da dieta de larvas de operárias e rainhas................................................. 15

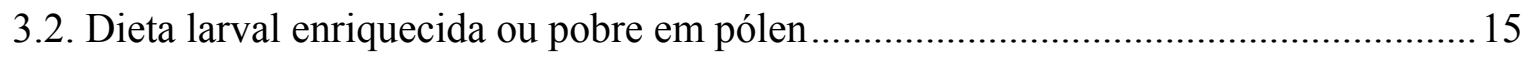

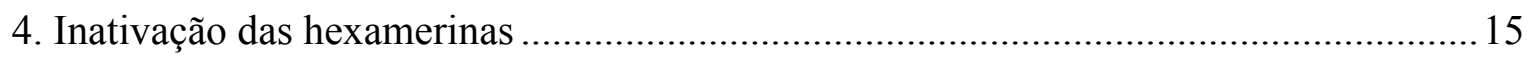

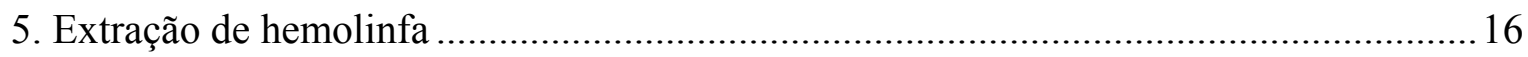

6. Separação de membranas e núcleos de células do corpo gorduroso................................ 16

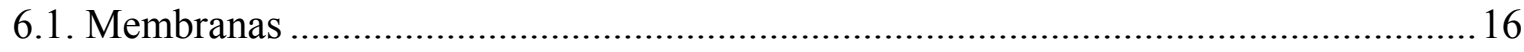

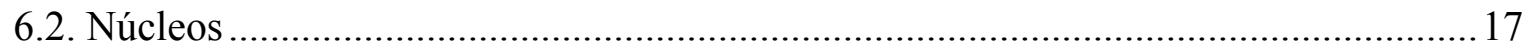

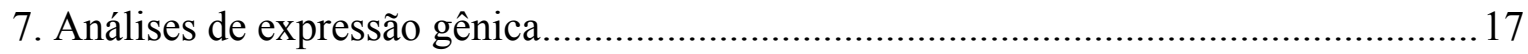

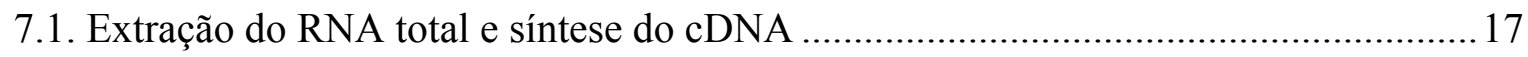

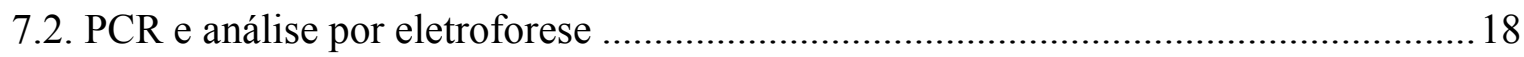

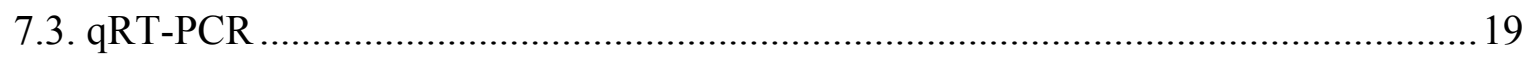

8. Imunolocalização das hexamerinas e busca de função ................................................. 21

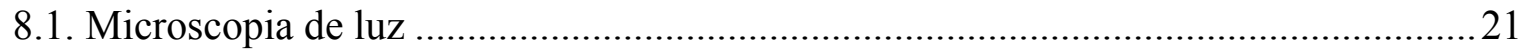

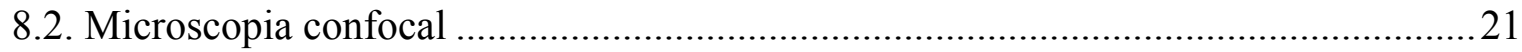

8.2.1. Marcação de F-actina com rodamina-faloidina................................................2 21

8.2.2. Imunolocalização da hexamerina HEX 70a nas gônadas..................................2

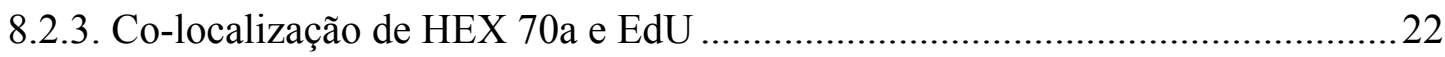

8.2.4. Marcação dos núcleos com DAPI e medição da largura dos ovaríolos .............22

8.2.5. Imunolocalização da hexamerina HEX 110 nos ovários de operárias adultas ( 7

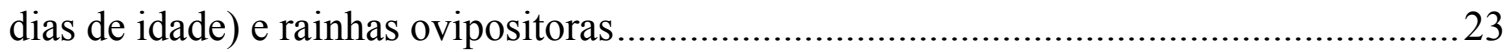

8.2.6. Imunolocalização das hexamerinas HEX 70a, HEX 70b, HEX 70c e HEX 110 no corpo gorduroso de operárias 
8.3. Microscopia eletrônica de transmissão para verificação da cutícula de operárias injetadas com anti-HEX 70a.

8.4. SDS-PAGE 24

8.4.1. Proteínas da hemolinfa, do corpo gorduroso, dos extratos de núcleo e de membranas .24

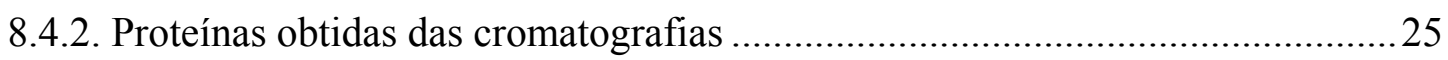

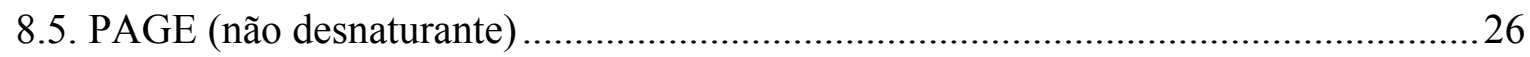

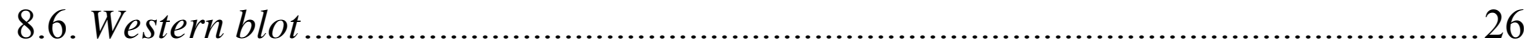

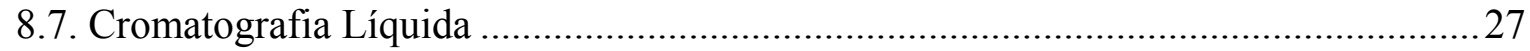

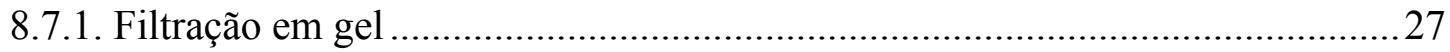

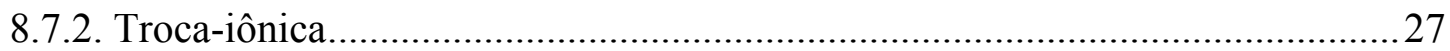

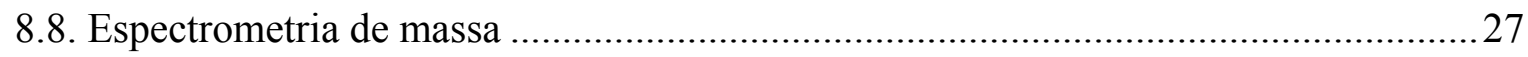

8.9. Teste de ligação de hexamerinas a extratos enriquecidos de membranas de corpo

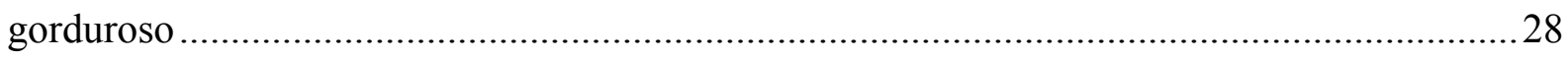

8.10. Expressão in vitro das hexamerinas em células de E. coli .......................................29

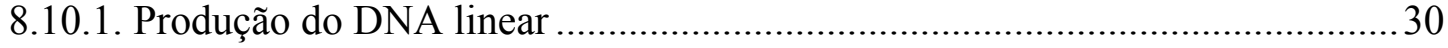

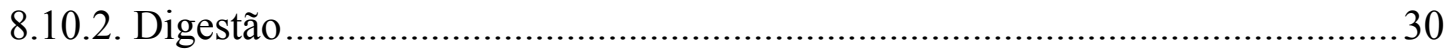

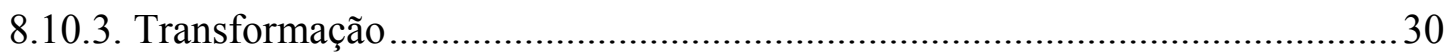

8.10.4. Preparo das células competentes E. coli de linhagens DH5 $\alpha$ e BL21 ............. 32

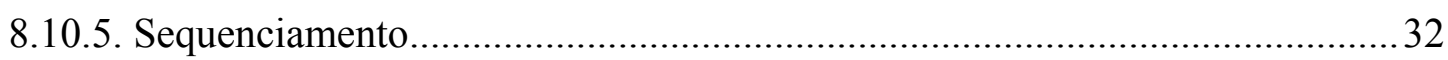

8.10.6. Preparo das linhagens de expressão ............................................................... 33

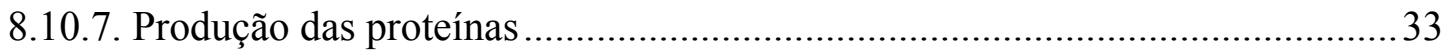

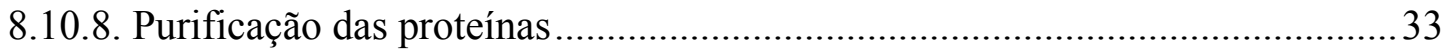

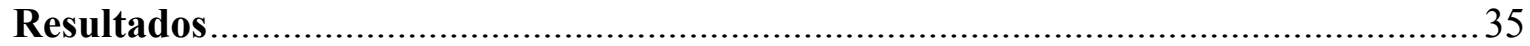

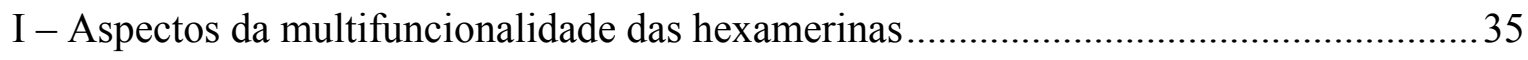

1. Dinâmica do acúmulo das subunidades de hexamerinas no corpo gorduroso e hemolinfa

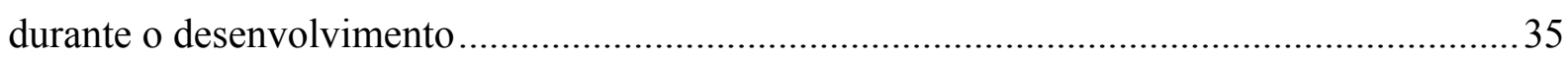

2. Detecção das hexamerinas no núcleo das células do corpo gorduroso.............................36

3. Imunolocalização das hexamerinas no citoplasma e no núcleo das células do corpo gorduroso. 37

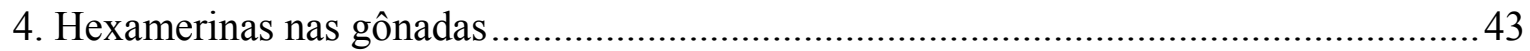

4.1. Imunolocalização da HEX 70a no núcleo das células ovarianas de operárias adultasfaratas

4.2. Imunolocalização de HEX 70a nos ovaríolos de rainhas ovipositoras. 
4.3. Imunolocalização da hexamerina HEX 110 em ovários de operárias adultas e rainhas ovipositoras..... 50

4.4. Imunolocalização de HEX 70a nos testículos .56

5. Colocalização de EdU e HEX 70a no núcleo das células ovarianas de operárias adultas faratas

6. Efeito da injeção do anticorpo anti-HEX 70a na largura dos ovaríolos e esclerotização cuticular.

7. Injeção de anticorpos anti-hexamerinas em operárias adultas faratas: efeito sobre a sobrevivência e duração do período adulto farato .67

II. Regulação da expressão dos genes de hexamerinas. 69

1. Efeito do HJ sobre a expressão dos genes de hexamerinas em larvas de $5^{\circ}$ instar. 69

2. Regulação da expressão dos genes de hexamerina pela dieta alimentar .70

2.1. Efeito da dieta oferecida à colmeia sobre o desenvolvimento larval e expressão dos genes de hexamerinas

2.2. Alternância da dieta de larvas de operárias e rainhas e efeitos sobre a expressão dos genes de hexamerinas .74

III. Características das subunidades HEX 70a, HEX 70b, HEX 70c e HEX 110...............76

1. Estudo da estrutura das subunidades de hexamerinas ................................................... 76

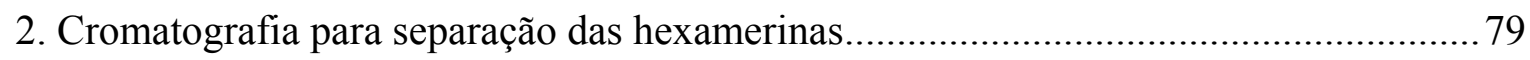

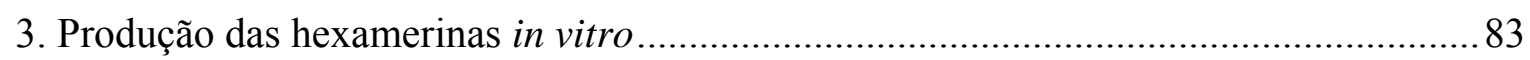

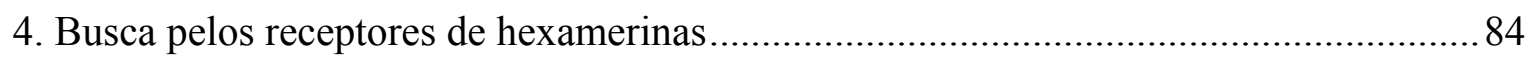

4.1. Análises in silico de sítios de fosforilação putativos nas hexamerinas preditas...........84

4.2. Busca por hexamerinas em amostras de concentrados de membranas do corpo gorduroso.

4.3. Teste de ligação de hexamerinas em extratos enriquecidos de membranas do corpo gorduroso.

Discussão.

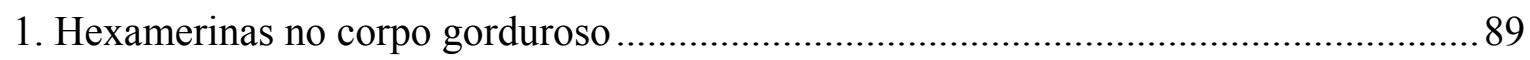

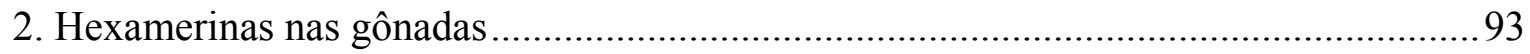

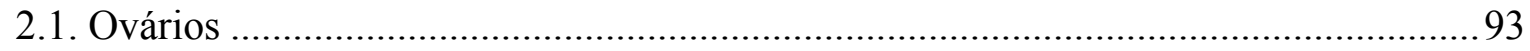

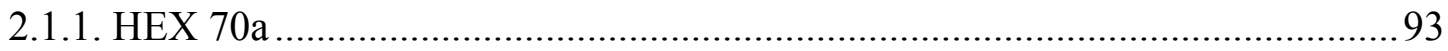

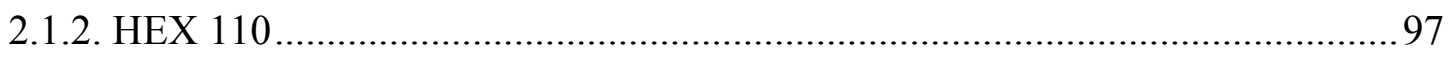

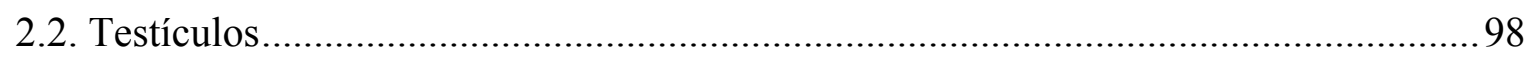

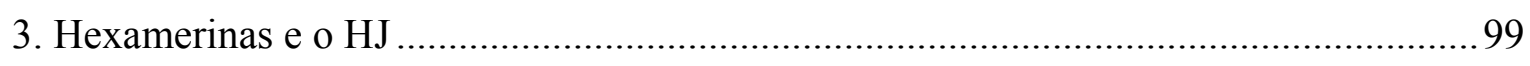

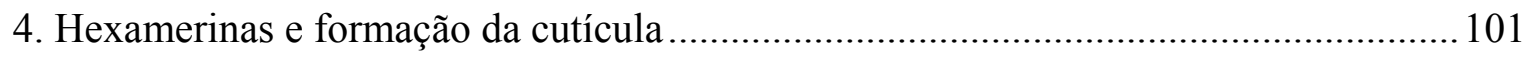




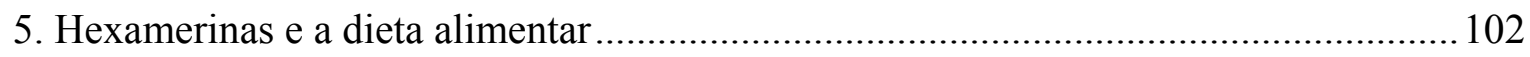

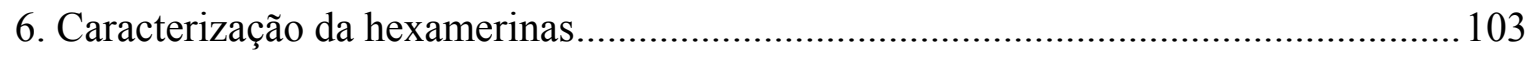

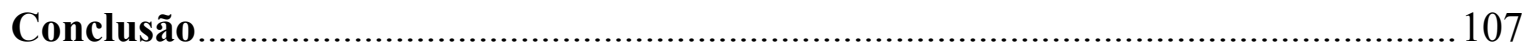

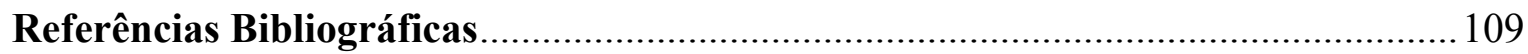

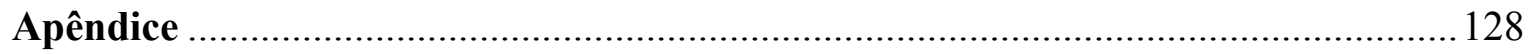




\section{Introdução}

\section{Aspectos da biologia de Apis mellifera}

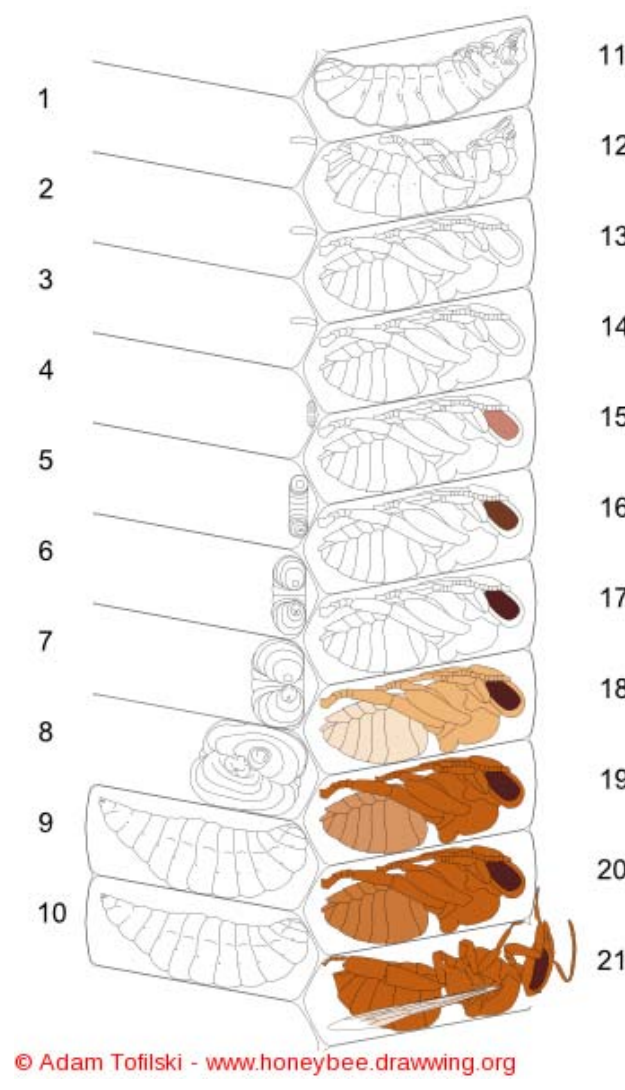

Figura 1: Ciclo de vida das abelhas operárias A. mellifera. 1-3: estágio embrionário. 4-8: do $1^{\circ}$ ao $5^{\circ}$ instar larval, fase de alimentação. 9: $5^{\circ}$ instar larval, fase de tecelagem do casulo. 10-12: pupas faratas. 13 e 14: pupas. 15-20: adultos faratos. 21: recém emergida (ecdise). Modificado de Winston (1991).
As abelhas são insetos holometábolos e, portanto, apresentam metamorfose completa com quatro estágios distintos de desenvolvimento: embrionário, larval, pupal e adulto (Fig. 1).

Os ovos são depositados pela rainha nos alvéolos dos favos de cera e, após três dias, as larvas eclodem iniciando um período marcado por um intenso crescimento corporal, que envolve uma série de mudas ou substituições periódicas do exoesqueleto (Snodgrass, 1956; Winston, 1991).

Cada ciclo de muda tem início quando os títulos de hormônios ecdisteróides aumentam na hemolinfa (Gilbert et al., 2002), fazendo com que o exoesqueleto existente se separe da epiderme em um evento definido como apólise. Na sequência, ocorre a síntese e secreção do novo exoesqueleto. Quando os títulos de ecdisteróides diminuem, o novo exoesqueleto é estabilizado por um processo denominado esclerotização, resultando em uma estrutura que varia regionalmente em sua espessura, elasticidade, cor e rigidez (Kayser, 1985; Hiruma e Riddiford, 1988; Hopkins e Kramer, 1992; Andersen, 2005). O velho exoesqueleto é em seguida descartado, caracterizando assim a ecdise para o estágio adulto.

Diferente das mudas larvais que resultam em aumento do tamanho corporal, a muda metamórfica é marcada pela morte celular programada dos tecidos e órgãos larvais e pelo desenvolvimento das estruturas do adulto. 
O tempo de duração da ontogênese difere entre os morfotipos que compõem a colmeia (Fig. 2). Rainhas, operárias e zangões completam o desenvolvimento em 16, 21 e 24 dias, respectivamente (Winston, 1991).

As fêmeas originam-se de ovos fecundados, diplóides, com potencial para originar tanto operárias quanto rainhas, dependendo da alimentação diferencial recebida durante o estágio larval. Larvas destinadas a se tornarem rainhas são alimentadas com grandes quantidades de geleia real, enquanto aquelas que se desenvolverão em operárias recebem geleia real suplementada com pólen e mel (Haydak, 1970). A dieta atua sobre o sistema neuroendócrino, gerando sinais casta-específicos responsáveis por alterações nos títulos do hormônio juvenil (HJ) e de ecdisteróides

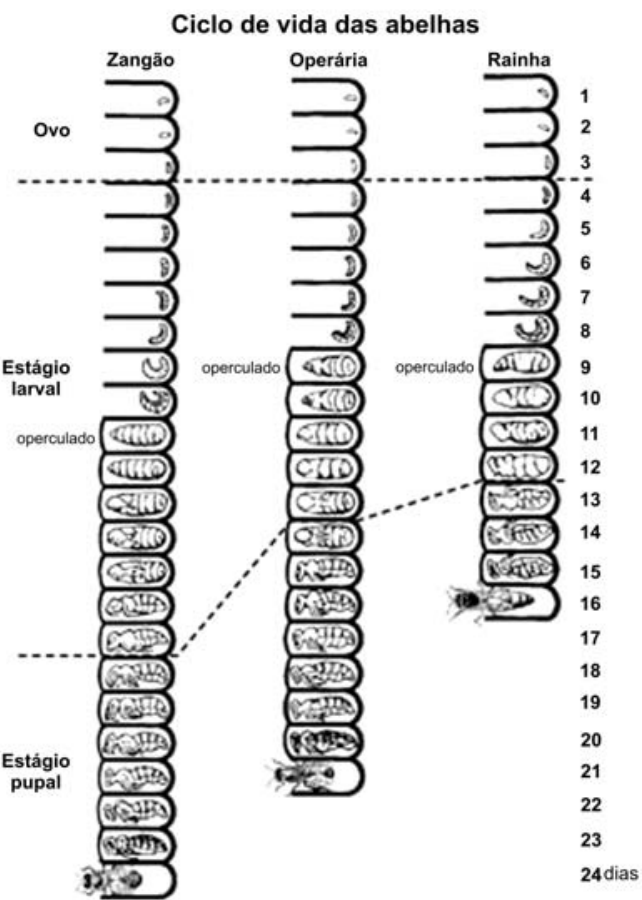

Figura 2: Ontogênese das abelhas $A$. mellifera: zangão, operária e rainha. Tempo em dias do desenvolvimento do ovo ao adulto recém-emergido. Modificado de Winston (1991).

(Rachinsky et al., 1990; Hartfelder e Engels, 1998), o que resulta em distintos perfis de expressão gênica (Cristino et al., 2006; Barchuk et al., 2007).

Um fator que regula o crescimento celular em resposta ao status nutritivo e que pode estar associado ao dimorfismo de castas (operárias e rainhas) é o gene target of rapamycin (TOR). Patel et al. (2007) mostraram que a dieta afeta a via de TOR e, consequentemente, aciona a via de insulina, regulando assim o crescimento corporal e o estoque de energia (Jia et al., 2004). Assim, o desenvolvimento de castas envolve a interação entre o gene TOR, a via de sinalização insulin/insulin-like signaling (IIS) e os títulos de HJ (Tatar et al., 2003).

Uma das diferenças mais marcantes entre a rainha e as operárias adultas reside no sistema reprodutivo. Uma rainha tem cerca de 200 ovaríolos por ovário e é capaz de produzir centenas de ovos por dia, ao passo que as operárias têm entre dois e 12 ovaríolos por ovário e não produzem ovos, a não ser em condições especiais (Velthuis, 1970). Tais diferenças têm origem durante o desenvolvimento larval, e são marcantes ao final do $5^{\circ}$ instar, período no qual cerca de $95 \%$ dos primórdios de ovaríolos sofrem morte celular programada nas larvas que se desenvolverão em operárias. Nas larvas destinadas a serem rainhas, os altos títulos de HJ previnem a degradação dos ovaríolos (Schmidt-Capella e Hartfelder, 1998) sendo possível visualizar alguns folículos pré-vitelogênicos poucos dias antes da emergência (Adams et al., 
1977; Estoup et al., 1994). Depois do vôo de acasalamento, os folículos se tornam vitelogênicos e os ovos passam a ser produzidos.

Os ovários de A. mellifera são do tipo meroístico politrófico (Fig. 3), onde cada ovaríolo é composto por filamento terminal (células indiferenciadas), germário (células germinativas e somáticas em diferenciação) e vitelário. $\mathrm{O}$ vitelário contém ovócitos em desenvolvimento e células nutridoras, ambos envoltos por uma bainha de células foliculares epiteliais (Ries, 1932; Patrício e Cruz-Landim, 2002).

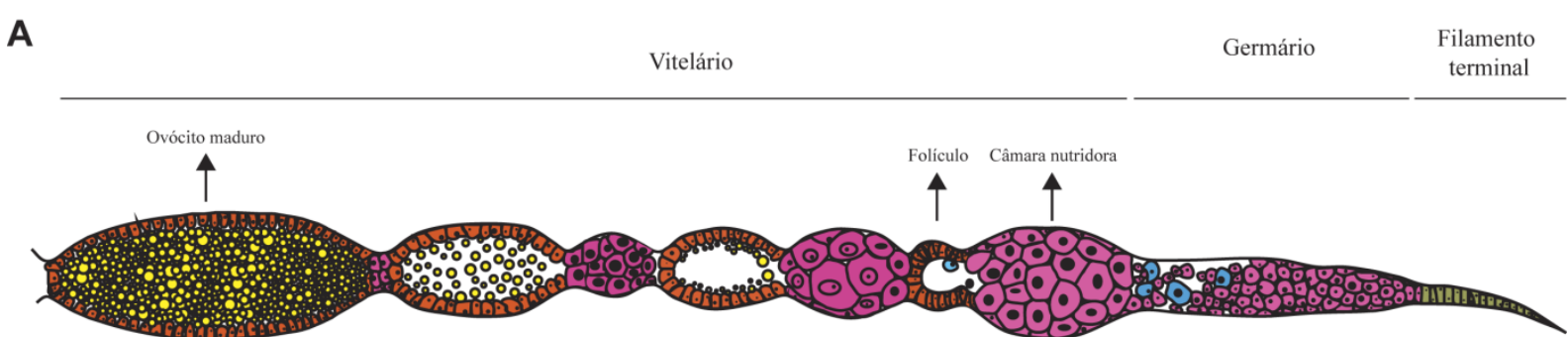

B

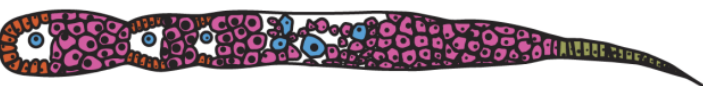

Figura 3: Esquema de ovaríolos de abelhas A. mellifera. (A) Rainha ovipositora. (B) Operária adulta. Em azul: núcleos de ovócitos. Laranja: células foliculares cúbicas rodeiam cada ovócito em crescimento. Células foliculares achatadas rodeiam cada câmara nutridora. Amarelo: vitelo. Verde: células indiferenciadas do filamento terminal. Adaptado de Cruz-Landim (2009).

O papel dos zangões de A. mellifera, os quais se originam dos ovos não fertilizados postos por rainhas ou operárias poedeiras. está fundamentalmente relacionado ao acasalamento e fecundação da rainha (Winston, 1991). O sistema reprodutivo dos zangões é composto pelos testículos, vesículas seminais e glândulas acessórias ou de muco (Snodgrass, 1956). As unidades estruturais dos testículos, os testíolos, são bem evidentes no $3^{\circ}$ instar larval e os agrupamentos de células germinativas em seu interior são observados no $4^{\circ}$ instar larval (Tozetto, 1997).

Durante o estágio pupal, as células germinativas sofrem meiose e tem início a espermiogênese e migração dos espermatozoides para a porção pré-ventricular dos ductos deferentes e para as vesículas seminais, onde são temporariamente armazenados. O final do processo de espermiogênese ocorre antes da emergência do zangão adulto (Bishop, 1920; Silveira, 1972; Kerr e Silveira, 1974; Louveaux, 1977; Tozetto, 1997), assim como o início da degeneração dos testículos (Snodgrass, 1956). 


\section{Hexamerinas}

Durante o estágio pupal o inseto holometábolo não se alimenta, mas utiliza proteínas abundantemente armazenadas na hemolinfa durante o estágio precedente, larval, como fonte de aminoácidos para o desenvolvimento (Burmester e Scheller, 1999). Estas proteínas são denominadas de proteínas de estocagem e as principais pertencem à classe das hexamerinas (Telfer e Kunkel, 1991), que integram uma família de proteínas composta por fenoloxidases, hemocianinas, pseudo-hemocianinas e receptores de hexamerinas (Burmester e Scheller, 1996; Burmester, 2001 e 2002). Ao contrário da ancestral hemocianina, as hexamerinas perderam a função respiratória, pois nelas os resíduos de histidina ligadores de íons $\mathrm{Cu}^{2+}$, necessários para o transporte de oxigênio, foram substituídos por outros aminoácidos (Beintema et al., 1994; Burmester, 2001 e 2002).

As hexamerinas têm grande massa molecular e consistem de seis subunidades, sendo a maioria entre 75 e 90 kDa (Scheller et al., 1990; Telfer e Kunkel, 1991). A reconstrução tridimensional de um complexo hexamérico de Cerura vinula (Lepidoptera), baseada em microscopia eletrônica de transmissão, revelou uma estrutura dupla-trimérica, ou seja, um dímero de trímeros (Kayser et al., 2009).

Essas proteínas são sintetizadas em grandes quantidades pelo corpo gorduroso larval em resposta à intensa ingestão de alimento, sendo subseqüentemente secretadas na hemolinfa, onde se acumulam em concentrações entre 60 e 90\% do total de proteínas circulantes (Scheller et al., 1990; Haunerland, 1996). Quando a larva pára de se alimentar, dá-se início ao seqüestro das hexamerinas pelas mesmas células do corpo gorduroso que as sintetizaram, onde serão armazenadas em forma de grânulos citoplasmáticos, que serão utilizados em processos do metabolismo intermediário para atender ao desenvolvimento pós-larval (Locke e Collins, 1965, 1966, 1967 e 1968; Levenbook e Bauer, 1984).

A seletividade do processo de endocitose, ou sequestro, das hexamerinas foi sugerida pela identificação de receptores específicos putativos nas membranas das células do corpo gorduroso de alguns Lepidoptera (Helicoverpa zea, Corcyra cephalonica) e de vários Diptera (Burmester e Scheller, 1992; Wang e Haunerland, 1994a; Kirankumar et al., 1997; Burmester e Scheller, 1999). Os receptores putativos de hexamerinas não pertencem a nenhuma classe conhecida de receptores de proteínas, mas são similares aos seus próprios ligantes, ou seja, às próprias hexamerinas, assim como a outros membros da família destas proteínas (Burmester e Scheller, 1996). Estudos recentes realizados em Achea janata (Lepidoptera) sugerem que os receptores de hexamerinas são proteínas ancoradas à face externa da membrana plasmática por meio de ligação covalente com o fosfolipídeo de membrana glicosil fosfatidil inositol 
(GPI). Proteínas deste tipo têm funções variadas (ativação celular, transdução de sinal, hidrólise de proteínas da matriz extracelular, adesão celular) e podem mediar o sequestro de ligantes (por exemplo, as hexamerinas) por meio de fosforilação (Budatha et al., 2011).

Diferentes hexamerinas coexistem em uma mesma espécie de inseto e suas origens têm sido atribuídas a eventos de duplicação gênica que resultaram em múltiplos parálogos (Burmester, 1999). Este fenômeno pode estar relacionado à aquisição de novas funções pelas diversas hexamerinas (Hagner-Holler et al., 2007). Algumas destas moléculas contêm em sua composição uma porcentagem relativamente alta de aminoácidos aromáticos (tirosina, fenilalanina e triptofano) e foram denominadas arilforinas. Outras são enriquecidas com metionina, ou glutamina (Telfer e Kunkel, 1991). É provável que estas particularidades sirvam para atender à necessidade de aminoácidos de diferentes tipos e quantidades durante o desenvolvimento pós-larval.

Neste contexto, há evidências circunstanciais de que certas hexamerinas participem do processo de esclerotização do exoesqueleto (Peter e Scheller, 1991). Outras teriam função no transporte de metabólitos ou hormônios (ecdisteróides e HJ), além de outros componentes orgânicos, como a riboflavina (Enderle et al., 1983; Magee et al., 1994; Braun e Wyatt, 1996; Nagamanju et al., 2003). Zalewska et al. (2009) mostraram que proteínas da hemolinfa, entre elas as hexamerinas, formam um complexo com proteínas ligadoras de HJ, auxiliando seu transporte às células alvo. Deste modo indireto, as hexamerinas estariam relacionadas à regulação dos títulos e ação do HJ. Esta propriedade das hexamerinas sugere que podem participar do processo de diferenciação de castas em cupins (Reticulitermes flavipes) que é desencadeada por este hormônio (Zhou et al., 2006a e b, 2007).

Além disto, a detecção de grânulos de hexamerinas no citoplasma das células do corpo gorduroso de alguns insetos adultos sugere que estas moléculas também constituem fontes de aminoácidos para a produção de proteínas do vitelo dos ovos e são, portanto, coadjuvantes no processo de reprodução (Wang e Haunerland, 1991; Roberts et al., 1991; Faria et al., 1994; Haunerland, 1996).

Experimentos com cultura de células intestinais de espécies de Lepidoptera (Spodoptera littoralis, Trichoplusia ni e Leptinotarsa decemlineata) mostraram que uma arilforina da hemolinfa induziu o aumento do número de células-tronco (Loeb, 2010). No entanto, o mecanismo pelo qual ocorre aumento da proliferação celular induzido por hexamerinas ainda não foi determinado. 


\section{Histórico do estudo de hexamerinas em Apis mellifera}

Ryan et al. (1984) foram os primeiros a identificar, por meio de SDS-PAGE, uma subunidade de $74 \mathrm{kDa}$ na hemolinfa de abelhas A. mellifera, à qual denominaram arilforina. Mais de uma década depois, Danty et al. (1998) demonstraram quatro subunidades de hexamerinas na hemolinfa desta abelha, as quais foram denominadas HEX 70a, HEX 70b, HEX 70c e HEX 80/110, de acordo com as massas moleculares das subunidades obtidas por SDS-PAGE. Estes autores também verificaram que as subunidades de $70 \mathrm{kDa}$ tinham Nterminais distintos, enquanto aquelas de massa molecular entre 80 e $110 \mathrm{kDa}$ compartilhavam uma sequência $\mathrm{N}$-terminal comum e possivelmente representavam isoformas secundárias de uma única sequência primária de aminoácidos. Assim, os dados de Danty et al. (1998) sugeriram a existência de, no mínimo, quatro diferentes genes de hexamerinas em $A$. mellifera.

Segue breve resumo dos estudos que se seguiram sobre a caracterização dos genes de hexamerinas e da expressão temporal de cada um deles nas operárias, rainhas e zangões, sob diferentes condições fisiológicas (naturais e manipuladas).

Cunha et al. (2005) tiveram como foco exclusivo o gene hex 70b. O cDNA foi completamente sequenciado e foi demonstrado que este gene está ativo em operárias durante o estágio larval. A redução da abundância de transcritos coincidia com a diminuição dos títulos de HJ e ecdisteróides que antecede a muda metamórfica, sugerindo regulação positiva, em nível de transcrição, por ambos os hormônios. Esta hipótese foi experimentalmente confirmada, uma vez que o tratamento de larvas de último estágio com estes hormônios impediu a redução dos níveis de transcritos, resultando em significativa extensão do período de expressão em comparação às larvas do grupo controle, não tratadas.

Bitondi et al. (2006) enfocaram o gene hex 110. Uma região de cDNA (correspondente a 180 nucleotídeos) foi sequenciada e foi verificado que em operárias, os níveis de transcritos são muito abundantes durante o estágio larval e início do estágio pupal, mas diminuem substancialmente em quantidade ao final deste estágio e durante a ecdise. Os níveis de transcritos aumentam novamente no estágio adulto, mas sem atingir a abundância verificada no estágio larval. Experimentos de manipulação da dieta alimentar e do status reprodutivo das operárias adultas mostraram que a expressão de hex 110 correlaciona-se positivamente com o consumo de pólen, a principal fonte de proteínas da dieta das abelhas, e com a presença de ovários ativos em operárias órfãs (que foram separadas da rainha e, portanto, liberadas do efeito repressor do feromônio real que impede sua reprodução). Estes 
resultados mostraram que o gene hex 110 é nutricionalmente regulado nas operárias adultas e que a reprodução demanda aumento de expressão deste gene.

Os estudos de Martins (2008) e Martins et al. (2008) tiveram como alvo o gene hex 70a. A densidade de transcritos de hex 70a no corpo gorduroso, assim como a abundância das respectivas subunidades polipeptídicas na hemolinfa, foram comparadas entre operárias, rainhas e zangões durante os estágios larval, pupal e adulto. Assim como hex 110, foi demonstrado que o gene hex $70 a$ é nutricionalmente regulado e sua expressão aumenta significativamente no corpo gorduroso de operárias com ovários ativos, sugerindo que seu produto pode ser requerido para uma função no contexto da reprodução. A presença de transcritos e de subunidades de HEX 70a nas gônadas em diferenciação de operárias, rainhas e zangões, conforme demonstrado por RT-PCR e western blot evidenciou um novo papel para esta hexamerina na biologia do desenvolvimento de A. mellifera.

Martins et al. (2010) aprofundaram e tornaram mais abrangente o enfoque sobre os genes de hexamerinas. $\mathrm{O}$ gene hex 110 foi completamente sequenciado, assim como hex 70c. Foi verificado que cada um dos genes de hexamerinas está presente como uma única cópia no genoma de A. mellifera: hex 70a, hex $70 b$ e hex 70c estão localizados in tandem no GroupUn.53, enquanto hex 110 está posicionado separadamente no Group11.32. O diagrama esquemático comparando a estrutura dos genes de hexamerinas, assim como suas sequências nucleotídicas constam do Apêndice 1 (Fig. 29). A contribuição de um dos co-autores do trabalho supra-citado (A. S. Cristino) levou à identificação de motivos conservados de resposta ao HJ nas respectivas regiões 5' UTR dos genes de hexamerinas, além da construção de uma árvore filogenética abrangendo 45 sequências conhecidas de hexamerinas de Hymenoptera, Diptera, Lepidoptera, Coleoptera, Isoptera e Orthoptera. Foram mapeados seis motivos super-representados numa extensão de 1,5 kb a partir (upstream) dos códons de início dos respectivos genes. Um dos motivos mostrou significante identidade com o sítio de ligação da proteína Ultraspiracle (USP), que compõe o complexo de ligação de ecdisteróides e HJ ao DNA (Yao et al., 1992 e 1993; Jones et al., 2006). Os outros cinco motivos não apresentaram similaridade com elementos de resposta conhecidos e parecem ser específicos de hexamerinas. A análise filogenética revelou um complexo padrão de evolução das hexamerinas, com radiação independente em cada uma das Ordens de insetos contemplada na análise. Revelou ainda que HEX 110, juntamente com as sequências HEX 109 e HEX 102 de outro Hymenoptera, a vespa parasita Nasonia, ocupa a posição mais basal entre as hexamerinas de insetos Holometabola conhecidas até então.

Estudos comparativos dos níveis de expressão de cada gene no corpo gorduroso, em etapas precisas da muda metamórfica, evidenciaram diferenças na modulação da expressão 
entre operárias, rainhas e zangões, neste período crítico do desenvolvimento, e também durante os estágios pupal e adulto (Apêndice 2 - Fig. 30). Os estudos comparativos foram estendidos às gônadas das fêmeas e dos zangões em desenvolvimento e adultos (Apêndice 3 Fig. 31). As análises por RT-PCR semi-quantitativa mostraram que além de expressar o gene hex 70a, conforme verificado anteriormente (Martins et al., 2008), os ovários e testículos em desenvolvimento também expressam hex 110 e hex 70b. Assim como hex70a, a expressão do gene hex 110 também foi identificada em ovários de rainhas em oviposição. O único gene de hexamerina aparentemente inativo nos ovários e testículos é hex 70c, uma vez que não foram identificados transcritos nestes órgãos.

Estes resultados podem ser assim resumidos: (1) os genes codificadores de hexamerinas de A. mellifera apresentam características estruturais peculiares indicando diversidade de funções no ciclo de vida; (2) os 4 genes de hexamerinas compartilham motivos super-representados na região reguladora 5', incluindo um motivo com potencial de ligar o receptor de $\mathrm{HJ}$, sugerindo que estes genes são regulados por $\mathrm{HJ}$; (3) todos os genes de hexamerinas mostram expressão abundante no corpo gorduroso larval de operárias, rainhas e zangões, corroborando a função canônica de genes codificadores de proteínas de estocagem para a metamorfose; os genes hex 110 e hex $70 a$ são também transcritos no corpo gorduroso dos adultos, com padrões de expressão casta e sexo específicos, sugerindo funções alternativas neste órgão dos adultos; (4) a expressão de três dos genes de hexamerinas (hex70a, hex $70 b$ e hex 110) nas gônadas de larvas e pupas de operárias, rainhas e zangões sugeriu função no desenvolvimento e diferenciação destes órgãos; (5) a expressão de hex $70 a$ e hex 110 nas gônadas de rainhas adultas sugeriu relação com o funcionamento dos ovários e reprodução.

Com o intuito de aprofundar este tema, procedemos à busca de evidências de funções alternativas das hexamerinas no contexto do desenvolvimento de A. mellifera, abrangendo diferentes fases do ciclo de vida. Também foram estudados aspectos da regulação dos genes de hexamerinas. Além disto, empreendemos esforços para isolar e purificar parcialmente estas proteínas, e paralelamente, iniciamos os procedimentos de transcrição/tradução in vitro das hexamerinas em bactérias visando obtê-las parcial ou totalmente purificadas para viabilizar a caracterização da estrutura dos hexâmeros e experimentos de ligação ao HJ. 


\section{Objetivos}

\section{Objetivo Geral:}

Este trabalho teve como objetivo geral a busca de evidências de funções alternativas das hexamerinas de A. mellifera, e o estudo de aspectos da regulação destes genes, principalmente no contexto da metamorfose do corpo gorduroso e desenvolvimento/maturação das gônadas.

\section{Objetivos Específicos:}

No contexto da metamorfose: (1) verificar a dinâmica de acúmulo de hexamerinas no corpo gorduroso e hemolinfa; (2) obter evidência de regulação dos genes de hexamerinas por HJ e pela dieta alimentar; (3) verificar as consequências da diminuição dos níveis de hexamerinas sobre o desenvolvimento; (4) determinar a localização de HEX 70a, HEX 70b, HEX 70c e HEX 110 nas células do corpo gorduroso de operárias durante a muda metamórfica;

No contexto do desenvolvimento/maturação das gônadas: (1) Determinar a localização das hexamerinas HEX 70a e HEX 110 nas células das gônadas de operárias, rainhas e zangões; (2) Investigar a relação entre HEX 70a, crescimento dos ovaríolos e esclerotização cuticular.

Como objetivo adicional, propusemos iniciar procedimentos para obter as hexamerinas parcialmente ou totalmente puras visando caracterizar a estrutura do hexâmero e aspectos específicos da funçã 
Material e Métodos 


\section{Material e Métodos}

\section{Material Biológico}

Abelhas africanizadas Apis mellifera foram obtidas no apiário experimental do Departamento de Genética da Faculdade de Medicina de Ribeirão Preto - Universidade de São Paulo (FMRP/USP).

\subsection{Operárias e rainhas em diferentes estágios e fases da ontogênese}

Rainhas ovipositoras foram confinadas em uma área limpa de um quadro de cria, por meio de uma tela excluidora de rainhas, durante 6 h. Finalizado o período determinado para a oviposição, a rainha foi retirada do confinamento, mas a tela excluidora foi mantida para evitar que novos ovos fossem depositados nos mesmos alvéolos.

Passados três dias, larvas de $1^{\circ}$ instar foram transferidas para cúpulas de rainhas contendo geleia real, sendo mantidas em colônias-recria até a emergência dos adultos. Algumas larvas foram mantidas no quadro de cria para a obtenção de operárias.

Larvas e pupas foram identificadas de acordo com os critérios de Rembold et al. (1980) e Michelette e Soares (1993), que apresentam um perfil detalhado do desenvolvimento pré-imaginal de $A$. mellifera baseado em características morfológicas e fisiológicas de rainhas e operárias, respectivamente (Tabela I). Assim, as larvas de rainhas e operárias foram agrupadas em cinco estágios distintos (L1, L2, L3, L4 e L5), definidos com base na ocorrência de ecdises. O $5^{\circ}$ e último instar larval é o mais longo, sendo subdividido em três fases: de alimentação (L5F), de tecelagem do casulo (L5S) e de pupa farata (PP) que representa o estágio de transição entre o estágio larval e o pupal. A pupa ( $\mathrm{Pw}$ ) e os adultos faratos em fases sucessivas de desenvolvimento ( $\mathrm{Pp}, \mathrm{Pdp}, \mathrm{Pb}, \mathrm{Pbl}, \mathrm{Pbm}$ e $\mathrm{Pbd}$ ) foram classificados usando como parâmetros a cor do olho e a pigmentação da cutícula torácica. 
Tabela I: Identificação dos estágios e fases de desenvolvimento de rainhas e operárias de Apis mellifera (Rembold et al., 1980; Michelette e Soares, 1993).

\begin{tabular}{|c|c|c|}
\hline \multirow[t]{2}{*}{ Instares larvais } & \multicolumn{2}{|c|}{ Intervalo de peso (mg) e características } \\
\hline & Operárias & Rainhas \\
\hline L1 & $0,11-0,30$ & $0,10-0,45$ \\
\hline L2 & $0,31-1,05$ & $0,35-1,50$ \\
\hline L3 & $1,50-4,45$ & $1,30-7,0$ \\
\hline L4 & $4,80-24,80$ & $3,80-44,00$ \\
\hline L5F1 & $27,12-42,62$ & $35,00-90,00$ \\
\hline L5F2 & $53,09-91,01$ & $91,00-180,00$ \\
\hline L5F3 & $106,78-115,86$ & $181,00-260,00$ \\
\hline L5S1 & \multicolumn{2}{|c|}{ Intestino totalmente cheio } \\
\hline L5S2 & \multicolumn{2}{|c|}{ Intestino em processo de esvaziamento } \\
\hline L5S3 & \multicolumn{2}{|c|}{ Intestino totalmente vazio } \\
\hline PP1 & \multicolumn{2}{|c|}{$\begin{array}{l}\text { Pouco movimento, cabeça orientada em direção ao opérculo, o } \\
\text { intestino pode ser visualizado como um tubo vazio. }\end{array}$} \\
\hline PP2 & \multirow{2}{*}{\multicolumn{2}{|c|}{$\begin{array}{l}\text { Imóvel, cabeça orientada em direção ao opérculo, o intestino não é } \\
\text { mais visível, os apêndices da cabeça e do tórax são visíveis através da } \\
\text { cutícula larval. } \\
\text { Imóvel, cabeça orientada em direção ao opérculo, o líquido exuvial } \\
\text { foi reabsorvido e a cutícula larval tornou-se opaca e enrugada. Apêndices } \\
\text { torácicos não podem mais ser visualizados. }\end{array}$}} \\
\hline PP3 & & \\
\hline Fases do estágio pupal & Cor do olho & $\begin{array}{l}\text { Pigmentação da cutícula } \\
\text { torácica }\end{array}$ \\
\hline $\mathrm{Pw}$ & Branco & Ausente \\
\hline $\mathrm{Pp}$ & Rosa claro & Ausente \\
\hline Pdp & Rosa escuro & Ausente \\
\hline $\mathrm{Pb}$ & Marrom & Ausente \\
\hline $\mathrm{Pbl}$ & Marrom & Início \\
\hline $\mathrm{Pbm}$ & Marrom & Intermediária \\
\hline $\mathrm{Pbd}$ & Marrom & Intensa \\
\hline
\end{tabular}

Operárias adultas foram obtidas em colmeias de acordo com a atividade exercida durante a coleta: nidal (recém-emergida e alimentação da cria) ou extra-nidal (forrageamento). Rainhas ovipositoras foram obtidas de diferentes colmeias, não importando a idade cronológica. 


\subsection{Obtenção de zangões}

Zangões foram coletados de colmeias em condições regulares (com rainha) e órfãs (sem rainha). As pupas foram identificadas de acordo com os critérios de Tozetto et al. (2007) (Tabela II), sendo classificadas em 13 estágios (P1, P2, P3, até P13), usando como parâmetros a cor do olho e a pigmentação da cutícula torácica.

Tabela II: Parâmetros para classificação de fases de desenvolvimento de zangões de Apis mellifera (Tozetto et al., 2007).

\begin{tabular}{cccc}
\hline & $\begin{array}{c}\text { Fases de pupa e } \\
\text { adulto farato }\end{array}$ & Cor dos olhos & Pigmentação da cutícula torácica \\
\hline Pupas & P1 & & Perolado \\
& P2 & Perolado & Perolado \\
Pupas & P3 & Bege & Perolado \\
& P4 & Rosa & Perolado \\
& P5 & Violeta & Perolado \\
& P6 & Violeta escuro & Pigmentação mesocutânea \\
& P7 & Violeta escuro & Marfim \\
P8 & Violeta escuro & Marfim \\
P9 & Violeta claro & Bege \\
& P10 & Violeta claro & Bege escuro \\
& P11 & Violeta claro & Marrom claro \\
P12 & Violeta claro & Marrom \\
& P13 & Marrom & Marrom escuro \\
\hline
\end{tabular}

\section{Tratamento hormonal}

Larvas L5F de operárias foram tratadas topicamente com $1 \mu \mathrm{L}$ de uma solução de 10 $\mu \mathrm{g} / \mu \mathrm{L}$ de hormônio juvenil III (Fluka) diluído em acetona. Larvas do grupo controle receberam $1 \mu \mathrm{L}$ do diluente. Após o tratamento, o quadro com as larvas tratadas foi devolvido à colmeia, onde permaneceu por $24 \mathrm{~h}$, quando os grupos tratados e controles foram coletados para análise por RT-PCR. 


\section{Manipulação da dieta alimentar}

\subsection{Alternância da dieta de larvas de operárias e rainhas}

Rainhas ovipositoras foram confinadas em uma área limpa de um quadro de cria, por meio de uma tela excluidora de rainhas, durante $6 \mathrm{~h}$. Metade das larvas de primeiro instar, 96 $\mathrm{h}$ após a postura, foram transferidas para realeiras, contendo geleia real, e a outra metade permaneceu no quadro de cria. Após 48 h, metade do grupo que estava nas realeiras foi transferido de volta para o quadro de cria, e metade do grupo que estava no quadro de cria foi transferido para novas realeiras. Passados mais dois dias, as larvas dos quatro grupos foram pesadas, o corpo gorduroso foi coletado para extração de RNA e análises por RT-PCR semiquantitativa, e a hemolinfa para análise de proteínas por western blot. Resumidamente, os grupos analisados eram constituídos por: 1) abelhas que permaneceram 4 dias em células de operárias (4Op); 2) abelhas que ficaram 2 dias em células de operária e 2 dias em células de rainha $(2 \mathrm{Op} 2 \mathrm{Ra}) ; 3)$ abelhas que ficaram 2 dias em células de rainha e 2 dias em células de operária (2Ra2Op); e 4) abelhas que permaneceram 4 dias em células de rainha (4Ra).

\subsection{Dieta larval enriquecida ou pobre em pólen}

Duas colônias de abelhas Apis mellifera foram confinadas em gaiolas de 2 × 2 × $2 \mathrm{~m}$, localizadas no apiário Experimental do Departamento de Genética da FMRP-USP. Nos três primeiros dias, estas colônias não receberam alimento para que o pólen estocado pelas operárias fosse totalmente consumido e, então, um quadro livre de alimento e cria foi utilizado para o confinamento da rainha para oviposição. A partir do quarto dia, as colônias receberam alimento composto por pólen comercial fermentado $(1 \mathrm{~kg}$ de pólen $+10 \mathrm{~mL}$ de mel, estocado em estufa, durante $24 \mathrm{~h}$, a $34^{\circ} \mathrm{C}$ e $80 \%$ de umidade relativa) em diferentes concentrações: 1) 5\% de pólen em xarope (50\% de açúcar em água); 2) 20\% de pólen em xarope. Os quadros foram acompanhados dia-a-dia e após 8 dias, larvas da postura controlada foram coletadas e pesadas. A hemolinfa foi estocada para análise por western blot e o RNA total foi extraído do corpo gorduroso para análise por RT-PCR e qRT-PCR.

\section{Inativação das hexamerinas}

Pupas $(\mathrm{Pw})$ de operárias e rainhas foram coletadas e mantidas em estufa a $34^{\circ} \mathrm{C}$ e $80 \%$ de umidade relativa por $24 \mathrm{~h}$ antes de receberem uma injeção de $1 \mu \mathrm{L}(1 \mu \mathrm{g})$ do anticorpo anti-HEX 70a, anti-HEX 70b, anti-HEX 70c ou anti-HEX 110 (Tabela III), diluído em 0,9\% $\mathrm{NaCl}$. O anticorpo foi injetado na hemocele abdominal, com o auxílio de uma micro seringa Hamilton (1701LT) e agulha G30 (Becton Dickinson). Para este experimento foram utilizados 
dois grupos controle que receberam $1 \mu \mathrm{L}$ de $\mathrm{NaCl} 0,9 \%$, ou $1 \mu \mathrm{L}(1 \mu \mathrm{g})$ de anticorpo antimouse diluído em $0,9 \% \mathrm{NaCl}$. Após 4 e 24 h da injeção, a hemolinfa e o corpo gorduroso de parte dos grupos tratados e controles foram coletados para análise por western blot. Parte dos grupos foram mantidos em estufa, nas mesmas condições acima mencionadas, até a emergência (ecdise), quando foram fotogrados. Uma vez que a hexamerina HEX 70a é uma arilforina e, dessa forma, podem estar relacionada com a formação da cutícula, o progresso da pigmentação e esclerotização foram examinados diariamente até a ecdise. Rainhas injetadas com anti-HEX 70a tiveram seus ovários dissecados e marcados com DAPI para medidas da espessura dos ovaríolos.

Tabela III: Sequências utilizadas para a produção dos anticorpos contra hexamerinas de A. mellifera

\begin{tabular}{ccc}
\hline Nome & Sequência & Empresa produtora \\
\hline anti-HEX 110 & NLYTKYHGQYP & Rheabiotech, Campinas, Brasil \\
anti-HEX 70a & SYKMHQKPYNKD & Affinity BioReagents, CO, USA \\
anti-HEX 70b & TFNLVENLDNYNDKEAVNEF & Rheabiotech, Campinas, Brasil \\
anti-HEX 70c & RNYDMESNMDMYKDKNVVQK & Rheabiotech, Campinas, Brasil \\
anti-mouse & Horseradish Peroxidase-linked whole & Kit ECL Western Blotting \\
& antibody & Detection Reagents and Analysis \\
& & System (Amersham Biosciences) \\
\hline
\end{tabular}

\section{Extração de hemolinfa}

A coleta de hemolinfa de operárias foi realizada através de incisão na cutícula abdominal dorsal das larvas e pupas pela qual inseriu-se um microcapilar. Às alíquotas de hemolinfa obtidas por sucção foi adicionado inibidor de protease (Protease Inhibitor Cocktail Tablets - Roche Applied Science) $(10 \% \mathrm{v} / \mathrm{v})$. As amostras foram centrifugadas a $3000 \mathrm{rpm}$ (mini Spin Eppendorf) por $3 \mathrm{~min}$. O sobrenadante foi coletado e estocado a $-20^{\circ} \mathrm{C}$.

\section{Separação de membranas e núcleos de células do corpo gorduroso}

\subsection{Membranas}

Larvas de $5^{\circ}$ instar (operárias) foram dissecadas para a extração do corpo gorduroso em tampão HEPES $_{1}$ gelado (5 mM HEPES, pH 8,5; $130 \mathrm{mM} \mathrm{NaCl} ; 5 \mathrm{mM} \mathrm{KCl} ; 0,1 \mathrm{M}$ $\mathrm{CaCl}_{2}$ ). O corpo gorduroso foi lavado (3 vezes) com tampão HEPES 2 (5 mM HEPES, pH 8,5; $0,1 \mathrm{mM} \mathrm{CaCl}_{2}$ ), para retirar a hemolinfa contaminante. Então $1,5 \mathrm{~mL}$ de tampão $\mathrm{HEPES}_{2}$ foi adicionado à amostra e, com o auxílio de uma seringa de insulina (1 mL/cc - INJEX indústrias cirúrgicas LTDA), o material foi homogeneizado. Após centrifugação a $2580 \mathrm{rpm}$ 
(Sorvall RC5C), por $10 \mathrm{~min}$, a $4^{\circ} \mathrm{C}$, o sobrenadante foi retirado e novamente centrifugado a $14000 \mathrm{rpm}$ (Sorvall RC5C) por $30 \mathrm{~min}$ a $4^{\circ} \mathrm{C}$. O pellet foi lavado com 1,5 mL de tampão $\mathrm{HEPES}_{2}$ e submetido a nova centrifugação nas mesmas condições da anterior. O pellet (fração de membranas) foi ressuspendido em 0,5 mL de tampão $\mathrm{HEPES}_{3}(10 \mathrm{mM} \mathrm{HEPES,} \mathrm{pH} \mathrm{7;} 2$ $\mathrm{mM} \mathrm{CaCl}_{2} ; 10 \%$ sacarose $\mathrm{p} / \mathrm{v}$ ), acrescido de $0,1 \%$ de Triton $\mathrm{X}-100$.

\subsection{Núcleos}

Larvas de $5^{\circ}$ instar (operárias) foram dissecadas para a extração do corpo gorduroso em $\mathrm{PBS}_{1}\left(137 \mathrm{mM} \mathrm{NaCl} ; 2,7 \mathrm{mM} \mathrm{KCl} ; 10 \mathrm{mM} \mathrm{Na}_{2} \mathrm{HPO}_{4} ; 1,7\right.$ mM KH $\mathrm{PO}_{4}, \mathrm{pH}$ 7.4). O corpo gorduroso foi lavado (3 vezes) com $\mathrm{PBS}_{1}$ para retirar a hemolinfa contaminante. Então, 1,5 $\mathrm{mL}$ de $\mathrm{PBS}_{1}$ e $25 \mu \mathrm{L}$ de inibidor de proteases foram adicionados à amostra, que foi centrifugada a $200-250 \mathrm{x}$, por $15 \mathrm{~min}$, a $4^{\circ} \mathrm{C}$. O sobrenadante foi descartado e $10 \mu \mathrm{L}$ de inibidor de proteases e $1 \mathrm{~mL}$ de tampão $\mathrm{HEPES}_{2}$ foram adicionados ao pellet, o qual foi homogeneizado com o auxílio de uma seringa de $3 \mathrm{~mL}$ e agulha número 26 por cerca de 10 vezes, e centrifugado a $1000 \times \mathrm{g}$ por $5 \mathrm{~min}$ a $4^{\circ} \mathrm{C}$. Ao pellet (fração nuclear) foram adicionados $2,5 \mu \mathrm{L}$ de inibidor de protease e $150 \mu \mathrm{L}$ de tampão uréia/CHAPS (uréia $8 \mathrm{M}$ e 2\% CHAPS). O pellet foi homogeneizado e levado ao ultrassom por $5 \mathrm{~min}$, e depois ao gelo por $5 \mathrm{~min}$ e ao vórtex por $5 \mathrm{~min}$ (este ciclo foi repetido 3 vezes). A amostra foi centrifugada a $20000 \mathrm{xg}$ por $30 \mathrm{~min}$ a $4^{\circ} \mathrm{C}$. O sobrenadante foi estocado em freezer $-80^{\circ} \mathrm{C}$.

\section{Análises de expressão gênica}

\subsection{Extração do RNA total e síntese do cDNA}

A extração de RNA foi feita utilizando reagente TRIzol® (solução comercial de fenol e isotiocianato de guanidina para isolamento de RNA total, Invitrogen). O protocolo de extração foi aquele recomendado pelo fabricante. Para tecidos contendo excesso de gordura (no caso de larvas de $5^{\circ}$ instar e amostras de corpo gorduroso) o passo de adição de clorofórmio foi repetido. O RNA obtido foi ressuspendido em água tratada com $0,1 \%$ dietilpirocarbonato (DEPC). A quantificação do RNA foi realizada em espectrofotômetro

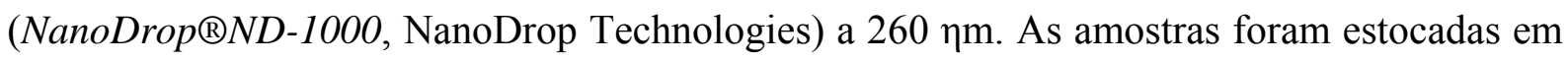
freezer $-80^{\circ} \mathrm{C}$.

O RNA foi tratado com DNase (Invitrogen) por 15 min em temperatura ambiente e em seguida a $65^{\circ} \mathrm{C}$ por $10 \mathrm{~min}$, para a inativação da enzima com a adição de $1 \mu \mathrm{L}$ de EDTA. A síntese de cDNA, a partir de 1-2,5 $\mu$ g de RNA total, foi feita de acordo com o sistema de síntese Superscript II (Invitrogen) e Oligo (dT)12-18 (Invitrogen), seguindo instruções do fabricante. Por este método, apenas a primeira fita do cDNA é sintetizada através de 
transcrição reversa. A segunda fita é gerada posteriormente por PCR com o uso de primers específicos.

\subsection{PCR e análise por eletroforese}

Para as amplificações por PCR foram utilizados os cDNAs e os primers específicos para cada gene (todos desenhados em exons diferentes, para controle de eventual contaminação por DNA genômico) e as condições de PCR específicas foram determinadas para cada par de primers (Tabela IV).

As reações foram realizadas com $0,8 \mu \mathrm{L}$ de primer forward e reverse $(1 \mu \mathrm{M}), 1 \mu \mathrm{L}$ de cDNA, $10 \mu \mathrm{L}$ de Master Mix 2,5X (Promega) \{10X PCR buffer [200 mM Tris- $\mathrm{HCl}(\mathrm{pH} 8,4)$, $500 \mathrm{mM} \mathrm{KCl}$; $50 \mathrm{mM} \mathrm{MgCl} 2 ; 25 \mathrm{mM}$ dNTP mix [100 mM de solução de: dTTP; dATP; dGTP e dCTP]; taq DNA polymerase [5 U/ $\mu \mathrm{L}]\}$, totalizando um volume de $20 \mu \mathrm{L}$ com água bidestilada estéril. O controle da amplificação foi realizado utilizando-se primers específicos para o gene codificador da proteína ribossomal rp49 de Apis mellifera (GenBank accession number AF441189; Tabela IV), de expressão constitutiva (Lourenço et al., 2008).

Aos cDNAs amplificados por PCR foram adicionados $2,5 \mu \mathrm{L}$ de tampão de amostra (50\% glicerol; $0,42 \%$ azul de bromofenol; $0,42 \%$ xileno cianol) para análise em gel de agarose 1\%, contendo brometo de etídio, em tampão TBE 1X (89 mM Tris, 89 mM ácido bórico, 2 mM EDTA, $\mathrm{pH}$ 8). A eletroforese foi realizada com uma corrente constante de 100 V. Após a eletroforese, o gel foi visualizado digitalmente com o uso de um fotodocumentador KODAK EDAS 290. O KDNA/Hind III Fragments de 100 pb (Invitrogen ${ }$, Life Technologies) ou 100 bp DNA Ladder (Promega) foi usado como marcador do tamanho dos produtos de PCR (fragmentos de DNA). 
Tabela IV: Sequências dos primers específicos e condições de PCR para análise semi-quantitativa

\begin{tabular}{|c|c|c|c|c|c|}
\hline $\begin{array}{c}\text { Versão } \\
\text { do } \\
\text { genoma }\end{array}$ & $\begin{array}{c}\text { Número } \\
\text { de acesso } \\
\text { no } \\
\text { GenBank }\end{array}$ & $\begin{array}{c}\text { Tamanho } \\
\text { do } \\
\text { fragmento }\end{array}$ & $\begin{array}{l}\text { Nome do } \\
\text { primer }\end{array}$ & Sequência (5'-3') & $\begin{array}{c}\text { Condições da } \\
\text { PCR }\end{array}$ \\
\hline 4.0 & EU105212 & $152 \mathrm{nt}$ & $\begin{array}{l}\text { Hex } 110 \mathrm{~F} \\
\text { Hex } 110 \mathrm{R}\end{array}$ & $\begin{array}{l}\text { GGCGGAGGAATTCAGCAAAA } \\
\text { TGGCCTACAGGATTCTGGAT }\end{array}$ & $\begin{array}{l}94^{\circ} \mathrm{C}-30 \mathrm{~s} ; 18 \\
\text { ciclos de } 94^{\circ} \mathrm{C}-30 \\
\mathrm{~s}, 58^{\circ} \mathrm{C}-1 \mathrm{~min}, \\
72^{\circ} \mathrm{C}-1 \mathrm{~min} \\
72^{\circ} \mathrm{C}-10 \mathrm{~min}\end{array}$ \\
\hline 4.0 & EF591128 & $109 \mathrm{nt}$ & $\begin{array}{l}\text { Hex 70a F } \\
\text { Hex 70a R }\end{array}$ & $\begin{array}{l}\text { AAAGCCAATCACGCTCTGAT } \\
\text { AATCGTGATTCAGATACCAGC }\end{array}$ & $\begin{array}{l}94^{\circ} \mathrm{C}-30 \mathrm{~s} ; 21 \\
\text { ciclos de } 94^{\circ} \mathrm{C}-30 \\
\mathrm{~s}, 54^{\circ} \mathrm{C}-1 \mathrm{~min}, \\
72^{\circ} \mathrm{C}-1 \mathrm{~min} \\
72^{\circ} \mathrm{C}-10 \mathrm{~min}\end{array}$ \\
\hline 4.0 & AY601637 & $132 \mathrm{nt}$ & $\begin{array}{l}\text { Hex 70b F } \\
\text { Hex 70b R }\end{array}$ & $\begin{array}{l}\text { ATACGACGAGTTCGGTCATG } \\
\text { ACGAAGACAGATTCGTGGCT }\end{array}$ & $\begin{array}{l}94^{\circ} \mathrm{C}-30 \mathrm{~s} ; 21 \\
\text { ciclos de } 94^{\circ} \mathrm{C}-30 \\
\mathrm{~s}, 54^{\circ} \mathrm{C}-1 \mathrm{~min}, \\
72^{\circ} \mathrm{C}-1 \mathrm{~min} ; \\
72^{\circ} \mathrm{C}-10 \mathrm{~min}\end{array}$ \\
\hline 4.0 & EF89162 & $130 \mathrm{nt}$ & $\begin{array}{l}\text { Hex 70c F } \\
\text { Hex 70c R }\end{array}$ & $\begin{array}{l}\text { TTACAAAACTGCCGCTTGGG } \\
\text { GGGATAGATCTCGTAGATGG }\end{array}$ & $\begin{array}{l}94^{\circ} \mathrm{C}-30 \mathrm{~s} ; 23 \\
\text { ciclos de } 94^{\circ} \mathrm{C}-30 \\
\mathrm{~s}, 54^{\circ} \mathrm{C}-1 \mathrm{~min} \\
72^{\circ} \mathrm{C}-1 \mathrm{~min} \\
72^{\circ} \mathrm{C}-10 \mathrm{~min}\end{array}$ \\
\hline 4.0 & AF441189 & $150 \mathrm{nt}$ & $\begin{array}{l}\text { Rp49 F } \\
\text { Rp49 R }\end{array}$ & $\begin{array}{l}\text { CGTCATATGTTGCCAACTGGT } \\
\text { TTGAGCACGTTCAACAATGG }\end{array}$ & $\begin{array}{l}94^{\circ} \mathrm{C}-30 \mathrm{~s} ; 25 \\
\text { ciclos de } 94^{\circ} \mathrm{C}-30 \\
\mathrm{~s}, 58^{\circ} \mathrm{C}-1 \mathrm{~min}, \\
72^{\circ} \mathrm{C}-1 \mathrm{~min} \\
72^{\circ} \mathrm{C}-10 \mathrm{~min}\end{array}$ \\
\hline
\end{tabular}

\section{3. qRT-PCR}

RT-PCR em tempo real foi realizada utilizando 7500 Real Time PCR System (Applied Biosystems). Diluições seriais de cDNA foram utilizadas para calcular a eficiência (E) das reações $\left(E=10^{(-1 / \text { slope })}\right)$ para cada gene. Os pares de primers escolhidos foram aqueles cuja eficiência ficou entre 1,9 e 2,05. A amplificação foi feita com $20 \mu \mathrm{L}$ de volume final, contendo $10 \mu \mathrm{L}$ de $S Y B R \circledR$ Green Master Mix 2X (Applied Biosystems), $1 \mu \mathrm{L}$ de cDNA (diluído 10X), 7,4 $\mu \mathrm{L}$ de água destilada e $0,8 \mu \mathrm{L}(1 \mu \mathrm{M})$ de cada primer específico (Tabela IV e V). Os primers foram desenhados para amplificar uma região de cada gene flanqueando um íntron, servindo assim como controle da contaminação por DNA genômico. Para checar a 
reprodutibilidade, o método foi realizado em triplicata técnica e triplicata biológica. As condições de PCR foram: $50^{\circ} \mathrm{C}$ por 2 min e $95^{\circ} \mathrm{C}$ por $10 \mathrm{~min}$, seguidos por 40 ciclos de $95^{\circ} \mathrm{C}$ por $15 \mathrm{~s}$ e $60^{\circ} \mathrm{C}$ por $1 \mathrm{~min}$. $\mathrm{O}$ gene $r p 49$ de A. mellifera codificador de uma proteína ribossomal de expressão constitutiva (Lourenço et al., 2008) foi utilizado para normalização e controle interno da PCR (Tabela IV). Cada corrida foi seguida por análise da curva de melting para confirmar a especificidade da amplificação e ausência de dímeros de primers. A quantificação relativa dos transcritos foi calculada usando o método comparativo $\mathrm{Ct}$ (Applied Biosystems, User bulletin \# 2).

Tabela V: Sequência dos primers específicos utilizados em análise por qRT-PCR

\begin{tabular}{|c|c|c|c|c|}
\hline $\begin{array}{c}\text { Versão } \\
\text { do } \\
\text { genoma }\end{array}$ & $\begin{array}{c}\text { Número } \\
\text { de acesso } \\
\text { no } \\
\text { GenBank }\end{array}$ & $\begin{array}{c}\text { Tamanho } \\
\text { do } \\
\text { fragmento }\end{array}$ & Nome do primer & Sequência (5'-3') \\
\hline \multirow[t]{2}{*}{4.0} & GB11059 & $149 \mathrm{nt}$ & Lipoforina $\mathrm{F}$ & AGCGAAGAGGATCGCAGATA \\
\hline & & & Lipoforina $\mathrm{R}$ & AАCCCTTCGTTCCTCCTTTC \\
\hline \multirow[t]{2}{*}{4.0} & GB10174 & $267 \mathrm{nt}$ & ILP2 F & ATGCACCAATATTATGGTCGAAC \\
\hline & & & ILP2 R & TTAACGGGCACCGCAATAGG \\
\hline \multirow[t]{2}{*}{4.0} & GB11037 & $119 \mathrm{nt}$ & Chico F & ACCAGCGAAAGTCATCCAAC \\
\hline & & & Chico R & GAGATTGGCGGTGAATAGGA \\
\hline \multirow[t]{2}{*}{4.0} & GB11213 & $128 \mathrm{nt}$ & Tor F & CTTCAAAAAGCCTGGACTGC \\
\hline & & & Tor R & GCAAGAGCCCAACATGATCT \\
\hline \multirow[t]{2}{*}{4.0} & AB490017 & $106 \mathrm{nt}$ & ecrA F & CCAACAGCAACAACGGCTAC \\
\hline & & & ecrA R & AAAGAGCCAGGCTGCGACAA \\
\hline \multirow[t]{2}{*}{4.0} & $\mathrm{AB} 490050$ & $86 \mathrm{nt}$ & ecrB F & ACAGTGTTGCCAACGGTCAC \\
\hline & & & ecrB R & AAAGAGCCAGGCTGCGACAA \\
\hline \multirow[t]{2}{*}{4.0} & AY273778 & $145 \mathrm{nt}$ & USP F & CGATATTCGACCGTGTCCTC \\
\hline & & & USP R & AGCAGGGTCACTTCCTGGAT \\
\hline \multirow[t]{2}{*}{4.0} & GB15634 & $145 \mathrm{nt}$ & MFE2 F & GGAATCATTTCTTGCGGAGA \\
\hline & & & MFE2 R & GTTATGCGCGCTATGGAAAT \\
\hline \multirow[t]{2}{*}{4.0} & AY647436 & $121 \mathrm{nt}$ & JHE F & AGATGCGCCCAGAGTAAAAA \\
\hline & & & JHE R & TTTCCCAACTGGAGGTAACG \\
\hline \multirow[t]{2}{*}{4.0} & XM394922 & $160 \mathrm{nt}$ & JHEH F & GCTTTTCAATTAGGTAGTGG \\
\hline & & & JHEH R & GATGGGAAATAGGTACCGAC \\
\hline
\end{tabular}




\section{Imunolocalização das hexamerinas e busca de função}

\subsection{Microscopia de luz}

Gônadas de rainhas, operárias e zangões foram dissecadas em Ringer $(\mathrm{NaCl}$ 0,17 M; $\mathrm{KCl}$ 0,01 M; $\mathrm{CaCl}_{2}$ 0,003 M) e fixadas em paraformaldeído $4 \%$ em $\mathrm{PBS}_{1}$, por $24 \mathrm{~h}, \mathrm{a}^{\circ} \mathrm{C}$. Os tecidos foram, então, desidratados em uma série crescente de etanol (70, 80, 90 e 95\%, 2 lavagens de 15 min cada) e infiltrados em resina de metacrilato por $24 \mathrm{~h} \mathrm{a} 4^{\circ} \mathrm{C}$, seguido de embebição na mesma resina acrescida de endurecedor (Historesin, Leica). Secções seriadas de $4 \mu \mathrm{m}$ de espessura foram realizadas em micrótomo (Micron) e transferidas para lâminas histológicas para coloração com azul de metileno e fucsina básica (21,8\% de azul de metileno $4 \mathrm{mM} ; 38 \%$ de tetraborato de sódio $26,2 \mathrm{mM} ; 27,2 \%$ de etanol absoluto; $13 \%$ de fucsina básica 3,8 $\mathrm{mM}$ ) por $5 \mathrm{~min}$, seguida de uma rápida lavagem com água destilada e estocagem em estufa a $37^{\circ} \mathrm{C}$ para secagem do material. Após a secagem das lâminas foram realizadas preparações permanentes com Entellan (Merck), e o material foi examinado e fotografado em microscocópio de luz Axioskop II photomicroscope (Zeiss).

\subsection{Microscopia confocal}

\subsubsection{Marcação de F-actina com rodamina-faloidina}

Após dissecção em $\mathrm{PBS}_{1}$, ovários e testículos foram imersos em meio de cultura específico para tecidos de abelhas (Rachinsky e Hartfelder, 1998), no qual foi realizada a individualização dos ovaríolos e testíolos e remoção da túnica peritoneal que os reveste. Ovaríolos e testíolos foram fixados por 30 min em solução contendo $240 \mu \mathrm{L}$ de $\mathrm{PBS}_{1}, 200 \mu \mathrm{L}$ de formaldeído 37\% (Merck), $8 \mu \mathrm{L}$ de Triton X-100 (Sigma) e $2 \mu \mathrm{L}$ de rodamina-faloidina (Invitrogen). $\mathrm{O}$ material foi lavado 2 vezes em solução de $\mathrm{PBS}_{1}$ com Triton $\mathrm{X}-100$ 0,2\% $(0,2 \%$ TPBS $)$ e $0,1 \%$ de rodamina-faloidina por $20 \mathrm{~min}$ cada. Uma terceira lavagem foi realizada em 0,2\% TPBS por 20 min. Ovaríolos e testíolos foram incubados por $5 \mathrm{~min}$ em DAPI (4,6-diamidino-2-phenylindole - Sigma) 1:8000 em 0,2\% TPBS e então lavados 5 vezes em 0,2\% TPBS por 5 min cada. Glicerol 80\% (Merck) em 0,2\% TPBS foi utilizado como meio de montagem e o material foi examinado em microscópio confocal Leica TCS-SP5 (Leica Microsystems, Bannockburn, IL).

\subsubsection{Imunolocalização da hexamerina HEX 70a nas gônadas}

Ovaríolos e testíolos foram fixados por $20 \mathrm{~min}$ sob agitação constante em paraformaldeído 4\% em $\mathrm{PBS}_{1}$, permeabilizados com 0,1\% TPBS por 15 min (5 lavagens), bloqueados com $0,1 \%$ TPBS e $1 \%$ BSA $\left(\mathrm{TPBSA}_{1}\right)$ por 30 min e incubados em $\mathrm{TPBSA}_{1}$ e $5 \%$ 
de soro de cabra, por $30 \mathrm{~min}$ à temperatura ambiente. Ovaríolos e testíolos foram então incubados com anti-HEX 70a em uma concentração de 1:50 em TPBSA 1 e 5\% de soro de cabra por $16 \mathrm{~h} \mathrm{a} 4^{\circ} \mathrm{C}$. Em sequência, o material foi lavado 5 vezes (20 min cada lavagem) em 0,1\% TPBS, bloqueado com $\mathrm{TPBSA}_{1}$ por $20 \mathrm{~min}$ (2 lavagens) e incubados em 5\% soro de cabra por 30 min. Cy3 goat anti-rabbit antibody (Sigma, 1:200 diluição) foi adicionado às amostras e estas foram incubadas por $2 \mathrm{~h}$ em temperatura ambiente. Ovaríolos e testíolos foram lavados com 0,1\% TPBS (5 lavagens de 20 min cada) e incubados com DAPI (1:8000 diluição) em $0,1 \%$ TPBS por 5 min e então lavados 5 vezes com $0,1 \%$ TPBS. Ovaríolos e testíolos foram montados em Glicerol 80\% (Merck) e examinados em Leica TCS-SP5 confocal microscope (Leica Microsystems, Bannockburn, IL).

\subsubsection{Co-localização de HEX 70a e EdU}

Pupas de operárias $\mathrm{Pw}$ foram coletadas e mantidas em estufa por $24 \mathrm{~h}$ a $34^{\circ} \mathrm{C}$ com $80 \%$ de umidade relativa. Com o auxílio de uma micro seringa Hamilton (1701LT) e agulha G30 (Becton Dickinson), $40 \mu \mathrm{M}$ de 5-ethynyl-2'deoxyuridine (EdU, Click-it ${ }^{\mathrm{TM}}$ EdU Imaging Kits - Invitrogen) diluído em Ringer foi injetado na hemocele da região abdominal. As pupas foram mantidas por mais $24 \mathrm{~h}$ em estufa a $34^{\circ} \mathrm{C}$ com $80 \%$ de umidade relativa, após as quais os ovários foram dissecados e fixados em 3,7\% formaldeído em $\mathrm{PBS}_{1}$ por 30 min, lavados em $\mathrm{PBS}_{1}$ por 20 min e, subsequentemente, transferidos para a solução de reação do Click-iT EdU Imaging Kit ( $43 \mu \mathrm{L}$ de $10 \mathrm{X}$ reaction buffer; $38 \mu \mathrm{L}$ de água destilada; $20 \mu \mathrm{L}$ de sulfato de cobre; 1,2 $\mu \mathrm{L}$ de Alexa Fluor 594; $50 \mu \mathrm{L}$ de reaction buffer additive) por $30 \mathrm{~min}$. A permeabilização e a marcação com anticorpo para localização da hexamerina HEX 70a foram realizadas conforme descrito no item 8.2.2.

\subsubsection{Marcação dos núcleos com DAPI e medição da largura dos ovaríolos}

Ovários de pupas de rainhas injetadas com anticorpo anti-HEX 70a e ovários do grupo controle injetado com $\mathrm{NaCl}$ 0,9\% foram dissecados e fixados em paraformaldeído 4\% em $\mathrm{PBS}_{1}$ por $20 \mathrm{~min}$. Os ovaríolos foram lavados três vezes com 0,2\% TPBS por 20 min e incubados com DAPI (1:8000 - Sigma) em 0,1\% TPBS por 5 min, seguido de 5 lavagens (5 min cada) em $0,1 \%$ TPBS. Os ovaríolos foram montados em Glicerol $80 \%$ e examinados em Leica TCS-SP5 confocal microscope (Leica Microsystems, Bannockburn, IL), utilizando o software do programa para a medição da largura dos ovaríolos em pontos específicos ao longo de seu eixo proximal-distal. 
8.2.5. Imunolocalização da hexamerina HEX 110 nos ovários de operárias adultas (7 dias de idade) e rainhas ovipositoras

Ovaríolos foram fixados por $20 \mathrm{~min}$ em paraformaldeído $4 \%$ em $\mathrm{PBS}_{1}$, permeabilizados com 0,1\% TPBS por 5 min (3 lavagens), bloqueados com $\mathrm{TPBSA}_{1}$ por 5 min (5 lavagens) e incubados em TPBSA 1 e $10 \%$ de soro de cabra, por $1 \mathrm{~h}$. Os ovaríolos foram então incubados com anti-HEX 110 a uma concentração de 1:50 em TPBSA 1 e 10\% de soro de cabra por $16 \mathrm{~h} \mathrm{a} 4^{\circ} \mathrm{C}$. Em sequência, o material foi lavado 3 vezes ( 5 min cada lavagem) e 5 vezes (20 min cada lavagem) em TPBSA 1 , e incubado com Alexa Fluor 488 conjugado com anticorpo anti-rabbit (Invitrogen, 1:200 diluição) em TPBSA $_{1}$ por $2 \mathrm{~h}$ em temperatura ambiente. Os ovaríolos foram lavados com TPBSA 1 (3 lavagens de 5 min e 5 lavagens de 20 min) e incubados com iodeto de propídeo (Invitrogen, $2 \mu \mathrm{g}$ por $\mathrm{mL}$ ), para marcação dos núcleos, em TPBSA 1 por 15 min e então lavados 3 vezes com TPBSA 1 por 5 min. Em seguida foram montados em Glicerol 80\% (Merck) e examinados em Leica TCSSP5 confocal microscope (Leica Microsystems, Bannockburn, IL).

\subsubsection{Imunolocalização das hexamerinas HEX 70a, HEX 70b, HEX 70c e HEX 110 no corpo gorduroso de operárias}

Corpo gorduroso de operárias em fase de pupa farata (PP2, Tabela I) foi fixado por 20 min em paraformaldeído $4 \%$ em $\mathrm{PBS}_{1}$, permeabilizado com $0,1 \%$ TPBS por 5 min (3 lavagens), bloqueado com $0,6 \%$ TPBS e $5 \%$ BSA (TPBSA $\left.{ }_{2}\right)$ por $5 \min (5$ lavagens) e incubado em $\mathrm{TPBSA}_{2}$ e $10 \%$ de soro de cabra, por $30 \mathrm{~min}$. Seguiu-se incubação com antiHEX 110, anti-HEX 70a, anti-HEX 70b ou anti-HEX 70c a uma concentração de 1:50 em $\mathrm{TPBSA}_{2}$ e $10 \%$ de soro de cabra por $16 \mathrm{~h}$ a $4^{\circ} \mathrm{C}$. Em sequência, o material foi lavado 3 vezes por 5 min e 5 vezes por 20 min em TPBSA 2 , e incubado com Alexa Fluor 488 (Invitrogen, diluição 1:200) em TPBSA 2 por $2 \mathrm{~h}$ em temperatura ambiente. Seguiram-se lavagens com $\mathrm{TPBSA}_{2}$ (3 lavagens de 5 min e 5 lavagens de $20 \mathrm{~min}$ ) e incubação com iodeto de propídeo (Invitrogen, $2 \mu \mathrm{g}$ por $\mathrm{mL}$ ) em $\mathrm{TPBSA}_{2}$ por $15 \mathrm{~min}$ e 3 lavagens com $\mathrm{TPBSA}_{2}$ por $5 \mathrm{~min}$. $\mathrm{O}$ corpo gorduroso foi montado em Glicerol 80\% (Merck) e examinado em Leica TCSSP5 confocal microscope (Leica Microsystems, Bannockburn, IL).

\subsection{Microscopia eletrônica de transmissão para verificação da cutícula de operárias injetadas com anti-HEX 70a}

As tíbias do $3^{\circ}$ par de pernas de operárias recém emergidas tratadas com anticorpo anti-HEX 70a e com $\mathrm{NaCl}$ 0,9\% na fase Pp (Tabela I) foram coletadas e fixadas em solução de glutaraldeído $4 \%$ em tampão cacodilato de sódio $0,1 \mathrm{M}, \mathrm{pH} 7,2$, por $1 \mathrm{~h}$ em temperatura 
ambiente e mais $24 \mathrm{~h}$ a $4^{\circ} \mathrm{C}$. Após a fixação, o material foi lavado em tampão cacodilato e pós-fixado em tetróxido de ósmio $1 \%$ em $\mathrm{PBS}_{1}$ e desidratado em série crescente de álcool 30, 50, 70, 90 e 95\%, (10 min cada), e 3 vezes em álcool 100\% (15 min cada). As amostras foram lavadas por 2 vezes por 10 min cada em óxido de propileno e infiltradas em araldite e óxido de propileno (1:1) por $16 \mathrm{~h}$ e em araldite e óxido de propileno (3:1) por $2 \mathrm{~h}$. Posteriormente, foram embebidas em araldite por $16 \mathrm{~h}$, a $60^{\circ} \mathrm{C}$, no vácuo. Secções com $0,5 \mu \mathrm{m}$ de espessura (Reichert $O M-V$ ultramicrotome) foram transferidas para lâminas histológicas e coradas com azul de toluidina $2 \%$ e examinadas em microscópio de luz para a identificação da área para realização dos cortes ultrafinos (60-70 $\mathrm{\eta m}$ de espessura). Os cortes ultrafinos foram transferidos para telas e contrastados com acetato de uranila $2 \%$ e citrato de chumbo $0,3 \%$ por 15 min e fotografados em microscópio eletrônico de transmissão (Jeol - Jem - 100 cx II electron microscope).

\subsection{SDS-PAGE}

\subsubsection{Proteínas da hemolinfa, do corpo gorduroso, dos extratos de núcleo e de membranas}

O teor de proteínas foi determinado por espectrofotometria (Beckman Coulter - DTX 880 Multimode Detector), pelo método de Bradford (1976), utilizando albumina sérica bovina para construção de curvas padrão. Alíquotas de amostras contendo 1-30 $\mu$ g de proteínas foram analisadas por SDS-PAGE e alíquotas contendo $5 \mu \mathrm{g}$ de proteínas foram submetidas a western blot. As proteínas foram separadas de acordo com suas massas moleculares por eletroforese em gel de poliacrilamida e SDS (dodecil sulfato de sódio), contendo 7,5\% da solução de acrilamida/bis-acrilamida. O procedimento baseou-se na descrição de Laemmli (1970), com algumas modificações. $\mathrm{O}$ gel de separação, medindo $12 \times 10$ x 0,09 cm, foi preparado com 2,5 $\mathrm{mL}$ de solução de acrilamida (30\%)/bis-acrilamida $(0,8 \%), 5 \mathrm{~mL}$ de tampão Tris-HCl 0,15 M pH 8,8, 2,3 mL de água destilada, $40 \mu \mathrm{L}$ de TEMED e $190 \mu \mathrm{L}$ de persulfato de amônia a $1 \%$. O gel de empilhamento (4,26\% de acrilamida/bis-acrilamida) foi preparado com $0,375 \mathrm{~mL}$ de acrilamida $(30 \%)$ /bisacrilamida $(0,8 \%), 1,38 \mathrm{~mL}$ de tampão Tris- $\mathrm{HCl} 0,024 \mathrm{M}$ pH 6,8, 0,825 $\mathrm{mL}$ de água destilada, $10 \mu \mathrm{L}$ de TEMED e $51 \mu \mathrm{L}$ de APS 5\%. O tampão usado nas cubas dos eletrodos era composto por 1,515 g de Tris-Base, 7,2 g de glicina, 0,5 g de SDS e $250 \mathrm{~mL}$ de água. Diferentes volumes de tampão para amostras (1,51 g de Tris-base, $20 \mathrm{~mL}$ de glicerol, 4 g SDS, $10 \mathrm{~mL}$ 2-mercaptoetanol, 0,002 g de bromofenol blue, água destilada até um volume total de $100 \mathrm{~mL}, \mathrm{pH}$ 6,75) foram adicionados às amostras, que foram desnaturadas a $100^{\circ} \mathrm{C}$ por 3 min e aplicadas em gel para migração durante $3 \mathrm{~h}$ a $4^{\circ} \mathrm{C}$, sob corrente de $15-20 \mathrm{~mA}$, 
juntamente com marcadores de massa molecular: Miosina, $\beta$-Galactosidase, Fosforilase-B, Albumina sérica bovina, Ovoalbumina e Anidrase Carbônica, com massas moleculares de 205, 116, 97, 66, 45 e $29 \mathrm{KDa}$, respectivamente.

Terminada a eletroforese, os géis foram corados com: 1) Coomassie Brillant Blue R$2501 \%$, dissolvido em uma solução contendo etanol, água e ácido acético (5:5:1 v/v); 2) Coomassie Coloidal [incubação prévia com fixador (10\% ácido acético; $40 \%$ etanol absoluto, $50 \%$ água milli-Q) por 16 h, e em seguida com 80\% de Coomassie Brillant Blue G-250 (5,87 $\mathrm{mL}$ ácido fosfórico; $50 \mathrm{~g}$ sulfato de amônio; 0,5 g Coomassie Brillant Blue G-250; água milliQ para completar $500 \mathrm{~mL}$ de solução) e 20\% de metanol] (Neuhoff et al., 1988) ; 3) Nitrato de Prata [incubação prévia com fixador (50\% metanol, 10\% ácido acético) por 30 min; lavagem com metanol 5\% por 15 min; 3 lavagens (5 min cada) com água milli-Q; incubação com tiossulfato de sódio ( $0,2 \mathrm{~g} / \mathrm{L}$ gelado) por $2 \mathrm{~min} ; 3$ lavagens (30 seg cada) com água milliQ; incubação com nitrato de prata $(0,2 \mathrm{~g} / 100 \mathrm{~mL}$ gelado) por $25 \mathrm{~min}$; 3 lavagens (1 min cada) com água milli-Q; revelação com carbonato de sódio (3 g/ $100 \mathrm{~mL}$ de carbonato de sódio; 50 $\mu \mathrm{L} / 100 \mathrm{~mL}$ de formaldeído 37\%, $2 \mathrm{~mL} / 100 \mathrm{~mL}$ de tiossulfato de sódio) por no máximo 10 min] (adaptado de Blum et al., 1987).

\subsubsection{Proteínas obtidas das cromatografias}

Alíquotas de amostras obtidas das cromatografias foram analisadas por SDS-PAGE. As proteínas foram separadas por eletroforese em gel de poliacrilamida, contendo gradiente de $6-12 \%$ da solução de acrilamida (30\%)/bis-acrilamida $(0,8 \%)$ [gel 6\% (2 mL de

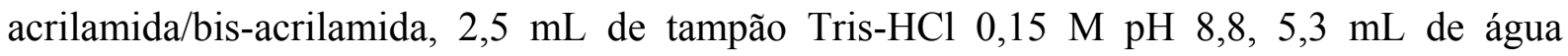
bidestilada, $0,1 \mathrm{~mL}$ de APS 10\%, 0,1 mL SDS 10\%; $6 \mu \mathrm{L}$ de TEMED) gel 12\% (4 mL de acrilamida/bis-acrilamida, 2,5 mL de tampão Tris- $\mathrm{HCl} 0,15 \mathrm{M} \mathrm{pH} \mathrm{8,8,3,3} \mathrm{mL}$ de água bidestilada, $0,1 \mathrm{~mL}$ de APS 10\%, 0,5 g sacarose, 0,1 mL SDS 10\%; $2 \mu \mathrm{L}$ de TEMED)].

O gel de empilhamento [ $5 \%$ de acrilamida( $30 \%) /$ bis-acrilamida $(0,8 \%)$ ] foi preparado com $0,830 \mathrm{~mL}$ de acrilamida $(30 \%) /$ bisacrilamida $(0,8 \%), 0,630 \mathrm{~mL}$ de tampão Tris-HCl $1 \mathrm{M}$ $\mathrm{pH}$ 6,8, 3,40 mL de água destilada, $5 \mu \mathrm{L}$ de TEMED e $50 \mu \mathrm{L}$ de persulfato de amônio $10 \%$. O tampão usado nas cubas dos eletrodos era composto por $25 \mathrm{mM}$ de Tris-Base, $192 \mathrm{mM}$ de glicina e $0,1 \%$ SDS. Diferentes volumes de tampão para amostras ( $2 \mathrm{~mL}$ de tampão Tris-HCl $50 \mathrm{mM}$ pH 6,8; 2 mL de glicerol; 4 mL SDS 10\%; 0,03 g de 100 mM DTT; água milli-Q para completar $10 \mathrm{~mL}$ de solução, $0,002 \mathrm{~g}$ azul de bromofenol) foram adicionados às alíquotas de proteínas. As amostras foram aplicadas em gel para migração durante $3 \mathrm{~h}$ a $19^{\circ} \mathrm{C}$, sob corrente de $20 \mathrm{~mA}$, juntamente com marcadores de massa molecular: Miosina, $\beta$-Galactosidase, 
Fosforilase-B, Albumina sérica bovina, Ovoalbumina e Anidrase Carbônica, com massas moleculares de 205, 116, 97, 66, 45 e $29 \mathrm{KDa}$, respectivamente.

Terminada a eletroforese, os géis foram corados com Coomassie Coloidal como descrito no item 8.4.1.

\subsection{PAGE (não desnaturante)}

Alíquotas de frações obtidas das cromatografias foram analisadas em géis de poliacrilamida contendo 5 - 12\% da solução de acrilamida/bis-acrilamida As amostras foram aplicadas em gel para migração durante $3 \mathrm{~h}$ a $19^{\circ} \mathrm{C}$, sob corrente de $20 \mathrm{~mA}$, juntamente com marcadores de massa molecular: contendo as proteínas tireoglobulina de tireoide bovina, ferritina de baço de cavalo, catalase de fígado bovino, aldolase muscular de coelho e albumina sérica bovina, com massas moleculares de 669, 440, 232, 158 e $67 \mathrm{KDa}$, respectivamente). Terminada a eletroforese, os géis foram corados com Coomassie Coloidal.

\subsection{Western blot}

Nos experimentos de western Blot, amostras de proteínas foram separadas por SDSPAGE e transferidas para membrana de PVDF (Bio-Rad, Immun-Blot ${ }^{\circledR}$ PVDF membrane), utilizando-se como tampão de transferência: $20 \mathrm{mM}$ Tris, $192 \mathrm{mM}$ Glicina e 20\% de etanol absoluto. A transferência ocorreu por $2 \mathrm{~h}$ à temperatura ambiente, a $30 \mathrm{~V}$.

Após a transferência as membranas foram coradas com solução de Ponceau (1 g do corante Ponceau em $200 \mathrm{~mL}$ de ácido acético 1\%), para verificar a eficiência da transferência, e lavadas em água destilada por cinco minutos. As membranas foram incubadas em solução bloqueadora (3,027 g Tris, $0,147 \mathrm{~g} \mathrm{CaCl}_{2}$ e 2,337 $\mathrm{g} \mathrm{NaCl}$, $\mathrm{pH} 8.5$, em um volume final de 250 $\mathrm{mL}, 50 \mathrm{~g}$ de leite em pó desnatado e $500 \mu \mathrm{L}$ de azida sódica $10 \%$, em um volume final de 500 $\mathrm{mL}$ ) por $16 \mathrm{~h}, \mathrm{a} 4^{\circ} \mathrm{C}$, seguida de incubação na mesma solução acrescida de anticorpo primário para a proteína de interesse, sob leve agitação, por $1 \mathrm{~h}$, em temperatura ambiente. Para os diferentes experimentos foram utilizados os seguintes anticorpos primários nas seguintes diluições: 1) Anti-HEX 110 (1:1000); 2) Anti-HEX 70a (1:5000); 3) Anti- HEX 70b (1:1000); 4) Anti-HEX 70c (1:1000).

Posteriormente, as membranas foram lavadas da seguinte forma: 2 lavagens rápidas de 5 min cada e 1 lavagem de 15 min à temperatura ambiente, sob leve agitação, em PBS-Tween (500 $\mu 1$ de Tween em $1 \mathrm{~L}$ de PBS 0,2 M, pH 7.2). Após as lavagens, as membranas foram incubadas, por $1 \mathrm{~h}$, com anticorpo secundário (1:12000) em PBS-Tween. O anticorpo secundário utilizado foi: anti-rabbit IgG, Horseradish Peroxidase-linked whole antibody, fornecido pelo fabricante do Kit ECL Western Blotting Detection Reagents and Analysis 
System (Amersham Biosciences). As membranas foram lavadas novamente, sob as mesmas condições descritas acima e, para a detecção do sinal quimioluminescente, foram incubadas em uma mistura dos reagentes de detecção do Kit ECL, por 1 min, no escuro. Em seguida, as membranas foram envolvidas em uma folha plástica, colocadas em cassetes e expostas a filmes autorradiográficos (Kodak ${ }^{\circledR}$ XR-Omat/ HyperfilmTM MP, Amersham Biosciences) durante 1-60 min. Os filmes foram revelados e fixados com as soluções GBX da Kodak ${ }^{\circledR}$.

\subsection{Cromatografia Líquida}

\subsubsection{Filtração em gel}

As hexamerinas da hemolinfa de larvas de operárias L5F foram separadas por meio de Cromatografia Líquida por filtração em gel (FPLC), utilizando o cromatógrafo Pharmacia FPLC System - Liquid Chromatography controller LCC-500. A FPLC foi realizada em coluna Superdex TM200 (10/300 GL; GE Healthcare). O tampão utilizado para a coluna foi Tris- $\mathrm{HCl} 50 \mathrm{mM}(\mathrm{pH} 7,5)$. Amostras de hemolinfa foram centrifugadas a $12000 \mathrm{rpm}$ (Eppendorf 5415) por 5 min e $100 \mu \mathrm{L}$ do sobrenadante foi injetado na coluna, submetida a um fluxo de $0,5 \mathrm{~mL} / \mathrm{min}$. A presença de proteínas nas frações foi determinada a $280 \mathrm{~nm}$.

\subsubsection{Troca-iônica}

Uma alíquota de $500 \mu \mathrm{L}$ das frações 2 e 3 obtidas na cromatografia por filtração em gel foi injetada em coluna Mono $Q^{\mathrm{TM}} H R$ 5/5 anion-exchange column (FPLC system, Pharmacia), conectada ao aparelho Pharmacia FPLC System - Liquid Chromatography controller LCC-500 Plus. Os tampões utilizados no sistema de vasos comunicantes foram: Tris-HCl $50 \mathrm{mM}(\mathrm{pH} 7,5)$ e Tris-HCl $50 \mathrm{mM}(\mathrm{pH} 7,5)$ acrescido de $1 \mathrm{M}$ de $\mathrm{NaCl}$. A taxa de fluxo foi de $0,5 \mathrm{~mL} / \mathrm{min}$. A presença de proteínas foi determinada a $280 \mathrm{~nm}$.

\subsection{Espectrometria de massa}

Bandas do gel SDS-PAGE contendo as proteínas de massas moleculares similares às hexamerinas foram lavadas com água milli-Q e descoradas com $50 \mu \mathrm{L}$ de acetonitrila $50 \%$ por aproximadamente $1 \mathrm{~h}$. As bandas foram submetidas a 3 lavagens com $50 \mu \mathrm{L}$ de $\mathrm{NH}_{4} \mathrm{HCO}_{3}$ $50 \mathrm{mM}$ e $50 \mu \mathrm{L}$ de acetronitrila $100 \%$, por $10 \mathrm{~min}$ cada. Em seguida, as bandas foram desidratadas no Savant SC110 SpeedVac por $10 \mathrm{~min}$. As amostras foram reduzidas em $50 \mu \mathrm{L}$ de $10 \mathrm{mM}$ DTT em $100 \mathrm{mM}$ de $\mathrm{NH}_{4} \mathrm{HCO}_{3}$, por $1 \mathrm{~h}$ a $56^{\circ} \mathrm{C}$ e alquiladas em $50 \mu \mathrm{L}$ de $55 \mathrm{mM}$ de acrilamida em $100 \mathrm{mM}$ de $\mathrm{NH}_{4} \mathrm{HCO}_{3}$, por $45 \mathrm{~min}$ em temperatura ambiente. Mais duas lavagens foram realizadas com $200 \mu \mathrm{L}$ de $100 \mathrm{mM}$ de $\mathrm{NH}_{4} \mathrm{HCO}_{3}$ e $200 \mu \mathrm{L}$ de acetonitrila $100 \%$, por 10 min cada. Na última lavagem com acetonitrila, as bandas foram maceradas com 
pistilo de plástico e colocadas em SpeedVac por 20 min. Aos fragmentos desidratados foram adicionados $10 \mu \mathrm{L}$ de solução de Tripsina gelada $\left[50 \mu \mathrm{L}\right.$ de $100 \mathrm{mM}$ de $\mathrm{NH}_{4} \mathrm{HCO}_{3}, 2,5 \mu \mathrm{L}$ de $200 \mathrm{mM}$ de $\mathrm{CaCl}_{2}, 1 \mu \mathrm{L}$ de Tripsina $0,2 \mu \mathrm{g} / \mu \mathrm{L}$ (Promega), 46,5 $\mu \mathrm{L}$ de água milli-Q]. Após incubação em gelo durante $40 \mathrm{~min}$, o excesso de Tripsina foi retirado e aos fragmentos foi adicionado $10 \mu \mathrm{L}$ de tampão de digestão $\left(50 \mu \mathrm{L}\right.$ de $100 \mathrm{mM}$ de $\mathrm{NH}_{4} \mathrm{HCO}_{3}, 2,5 \mu \mathrm{L}$ de $200 \mathrm{mM}$ de $\mathrm{CaCl}_{2}, 47,5 \mu \mathrm{L}$ de água milli-Q) para incubação a $37^{\circ} \mathrm{C}$ por $16 \mathrm{~h}$.

Em cada amostra digerida, foi adicionado $1 \mu \mathrm{L}$ de TFA 0,1\% para acidificação. Assim, $1 \mu \mathrm{L}$ de cada amostra foi aplicado no Bruker Anchorchip ${ }^{\mathrm{TM}}$ e incubado em temperatura ambiente até secagem completa. Um volume de $0,5 \mu \mathrm{L}$ de matriz $\mathrm{DHB}(2,5-$ dihydroxybenzoic acid matrix substance for MALDI-MS - Fluka) foi adicionado às amostras que foram incubadas em temperatura ambiente até secagem completa. $\mathrm{O}$ chip foi colocado no espectrômetro de massa Bruker Daltonics AutoflexII Maldi TOF/TOF. Os picos de tripsina e queratina foram removidos com o uso de Peptide MIX (Bruker Daltonics). Os espectros obtidos foram analisados em Mascot software, assumindo $\mathrm{P}<0,05$ (Perkins et al., 1999) para busca das proteínas no Banco de Dados do NCBI (www.ncbi.nlm.nih.gov).

\subsection{Teste de ligação de hexamerinas a extratos enriquecidos de membranas de corpo gorduroso}

Proteínas extraídas da membrana do corpo gorduroso (item 6.1) foram utilizadas para a identificação dos possíveis receptores de hexamerinas. Para isso, $10 \mu \mathrm{g}$ do extrato de proteínas de membrana foram submetidos à eletroforese em gel SDS-PAGE 7,5\% e as bandas foram transferidas para membrana PVDF. As membranas foram lavadas (3 vezes de $10 \mathrm{~min}$ cada) com $50 \mathrm{~mL}$ de $50 \mathrm{mM}$ Tris- $\mathrm{HCl}(\mathrm{pH} 7,4)$ e $150 \mathrm{mM} \mathrm{NaCl}$ e incubadas por $16 \mathrm{~h}$, a $4^{\circ} \mathrm{C}$, com $50 \mathrm{~mL}$ de tampão de bloqueio [50 mM Tris- $\mathrm{HCl}(\mathrm{pH} 7,4), 150 \mathrm{mM} \mathrm{NaCl}, 2 \% \mathrm{BSA}$, $0,2 \%$ de Blocking reagent (ECL)]. Posteriormente, as membranas foram lavadas (3 vezes de 10 min cada) com tampão de ligação [5 mM MES (pH 6,5), $100 \mathrm{mM} \mathrm{NaCl}, 8 \mathrm{mM} \mathrm{CaCl} 2,24$ $\mathrm{mM} \mathrm{MgCl} 2,0,5 \%$ Tween-20 (v/v), $5 \mathrm{mg} / \mathrm{mL}$ de BSA] e incubadas a $22^{\circ} \mathrm{C}$, por $4 \mathrm{~h}$, com 50 $\mathrm{mL}$ do tampão de ligação e $1 \mathrm{~mL}$ de hemolinfa. Após esse período, as membranas foram lavadas (3 vezes de 10 min cada) com tampão de bloqueio e incubadas com anticorpo primário das hexamerinas (HEX 110, HEX 70a e HEX 70b) por $1 \mathrm{~h}$. As membranas foram novamente submetidas a 3 lavagens de 10 min com tampão de bloqueio e foram incubadas com anticorpo secundário (1:12000 - anti-rabbit IgG, Horseradish Peroxidase-linked whole antibody, fornecido pelo fabricante do Kit ECL Western Blotting Detection Reagents and Analysis System - Amersham Biosciences), por $1 \mathrm{~h}$. As membranas foram lavadas novamente (3 vezes de 10 min cada) com tampão de bloqueio e reveladas conforme descrito no item 8.6. 
Posteriormente, $10 \mu \mathrm{g}$ do extrato de proteínas de membrana foram submetidos à eletroforese em gel SDS-PAGE 7,5\% e corados com Coomassie Coloidal (ver item 8.4.1). As bandas correspondentes àquelas obtidas por western blot foram recortadas, secas em speed vac e enviadas para análise por espectrometria de massa (Instituto Pasteur de Montevidéu).

\subsection{Expressão in vitro das hexamerinas em células de $E$. coli}

As sequências completas dos genes hex 110, hex 70a, hex 70c e hex 70c, foram submetidas a análise no programa NEBcutter V2.0 (htpp://tools.neb.com/NEBcutter2) para a escolha do melhor vetor de expressão para inserção de cada uma destas sequências. $O$ vetor escolhido foi o pET-28a, que apresenta sítios de restrição para as enzimas EagI, NcoI e XbaI, e ainda carrega uma cauda de histidina tanto na região N-terminal quanto na C-terminal, flanqueadas por sítios para ligação da T7 RNA polimerase. Primers específicos foram desenhados nas extremidades 5' e 3' dos genes (Tabela VI). Na extremidade 5', o fragmento que contém o peptídeo sinal foi excluído das análises, uma vez que ele é clivado, e um ATG foi adicionado. Na extremidade 3', o stop códon de cada gene foi substituído pelo stop códon da bactéria a ser utilizada para a produção das proteínas.

Tabela VI: Sequência dos primers desenhados para expressão in vitro das hexamerinas e escolha das enzimas de restrição. Sítios de restrição estão sublinhados.

\begin{tabular}{|c|c|c|}
\hline Nome & Sequência (5'-3') & $\begin{array}{c}\text { Enzima de } \\
\text { restrição }\end{array}$ \\
\hline $\begin{array}{c}\text { Hex 70b } \\
\text { FWD }\end{array}$ & ATCTAGAAAATGGTGCCCAACAAGGTCGC & XbaI \\
\hline $\begin{array}{c}\text { Hex 70b } \\
\text { REV }\end{array}$ & ATCC $\underline{G G C C G T A G C A G A G C A A C G T T C A A C T C C T C ~}$ & EagI \\
\hline $\begin{array}{c}\text { Hex } 110 \\
\text { FWD }\end{array}$ & AGCCCATGGTCATGCTGTGCCCCCAACGTCAAAC & NcoI \\
\hline $\begin{array}{c}\text { Hex } 110 \\
\text { REV }\end{array}$ & ATCC $\underline{G C C G T A G C T G A G T G A T G T C A T T G G T G G G T}$ & EagI \\
\hline $\begin{array}{c}\text { Hex 70a } \\
\text { FWD }\end{array}$ & AGCCCATGGTCATGCGGTGCAGAATATTACGACACGAA & NcoI \\
\hline $\begin{array}{c}\text { Hex 70a } \\
\text { REV }\end{array}$ & ATCCGGCCGTAGTAATAAGTGATATTCATATCAAATTCATCC & EagI \\
\hline $\begin{array}{c}\text { Hex 70c } \\
\text { FWD }\end{array}$ & AGCCCATGGTCATGGCCTCCTACGCAGGAAGGC & NcoI \\
\hline $\begin{array}{c}\text { Hex 70c } \\
\text { REV }\end{array}$ & ATCCGGCCGTAGAGTAATTCATACTCTCCTCGTTTG & EagI \\
\hline
\end{tabular}




\subsubsection{Produção do DNA linear}

Os primers específicos para os genes de interesse foram utilizados em reações de PCR com a enzima Platinum Taq DNA polymerase High Fidelity (Invitrogen), seguindo as instruções do fabricante ( $5 \mu \mathrm{L}$ PCR buffer, $1 \mu \mathrm{L}$ dNTP $10 \mathrm{mM}, 2 \mu \mathrm{L} \mathrm{MgSO}_{4}, 36,8 \mu \mathrm{L}$ de água destilada, $2 \mu \mathrm{L}$ de primer forward, $2 \mu \mathrm{L}$ de primer reverse, $0,3 \mu \mathrm{L}$ de taq High Fidelity, $1 \mu \mathrm{L}$ de cDNA). Para tanto foi utilizado cDNA de larva de operária L4 (Tabela I). As reações ocorreram sob as seguintes condições: $94^{\circ} \mathrm{C}$ por 2 min, seguidos de 30 ciclos a $94^{\circ} \mathrm{C}$ por $30 \mathrm{~s}$, $55^{\circ} \mathrm{C}$ por $30 \mathrm{~s} \mathrm{e} 68^{\circ} \mathrm{C}$ por $3 \mathrm{~min}$, e uma extensão final de $4^{\circ} \mathrm{C}$. Uma alíquota do produto de PCR foi submetida a eletroforese em gel de agarose $0,8 \%$ (em tampão TAE $1 \mathrm{X}-0,04 \mathrm{M}$ Tris base, $1 \mathrm{M}$ ácido acético, $50 \mathrm{mM}$ EDTA, pH 8,0) para a confirmação da amplificação e tamanho dos fragmentos. O restante do produto de PCR foi purificado usando o Kit Illustra ${ }^{\mathrm{TM}}$ GFX ${ }^{\mathrm{TM}}$ PCR DNA e Gel Band Purification kit (GE) e a quantidade de DNA obtida foi quantificada por espectrofotometria (Nanodrop ${ }^{\circledR} N D-1000$, NanoDrop Technologies).

\subsubsection{Digestão}

A digestão foi realizada tanto para os produtos de PCR purificados quanto para o plasmídeo pET-28a, usando 1,5 $\mu \mathrm{g}$ de DNA. Para clonagem do gene da HEX 70b, o produto de PCR e o vetor foram digeridos com as enzimas EagI e XbaI. Para as outras hexamerinas foram utilizadas as enzimas EagI e NcoI. Esse processo ocorreu a $37^{\circ} \mathrm{C}$ por $1 \mathrm{~h}$ e em seguida a $65^{\circ} \mathrm{C}$ por 20 min para inativação das enzimas. O produto obtido foi aplicado em gel de agarose $0,8 \%$ (em tampão TAE). As bandas foram recortadas e purificadas (Wizard ${ }^{\circledR} S V$ Gel and PCR Clean-up System - Promega). O DNA obtido foi quantificado por espectrofotometria (Nanodrop ${ }^{\circledR} N D-1000$, NanoDrop Technologies) e utilizado para a ligação dos genes de hexamerinas aos plasmídeos. A ligação foi feita a $4^{\circ} \mathrm{C}$ por um período de $16 \mathrm{~h}$.

\subsubsection{Transformação}

O produto da ligação foi dialisado em água destilada, com o auxílio de um filtro de $0,025 \mu \mathrm{m}$ (Millipore), por um período de 20 a $30 \mathrm{~min}$. O produto livre de sais foi coletado e 5 $\mu \mathrm{L}$ foram utilizados para transformar bactérias E. coli DH5 $\alpha$ por choque térmico e ou por eletroporação. As bactérias acrescidas do produto dialisado foram incubadas a $42^{\circ} \mathrm{C}$ por 2 min e em gelo por $5 \mathrm{~min}$. As bactérias tranformadas por eletroporação foram colocadas em cubetas (Gene Pulser Curvette, Bio-Rad) e submetidas a um pulso de 2,5 V (Gene Pulser II e Pulser Controller Plus, Bio-Rad). Para recuperar as bactérias, $0,5 \mathrm{~mL}$ de meio LB líquido, sem antibiótico, foi utilizado para ressuspender as bactérias, que foram deixadas sob leve agitação a $37^{\circ} \mathrm{C}, 190 \mathrm{rpm}$, por $1 \mathrm{~h}$. As bactérias foram submetidas à centrifugação (13000 rpm por 2 
min - Eppendorf 5415 R), 80\% do sobrenadante foi descartado e o restante foi utilizado para o plaqueamento em meio LB sólido contendo canamicina $(15 \mu \mathrm{g} / \mu \mathrm{L})$. As placas de cultivo foram incubadas a $37^{\circ} \mathrm{C}$ por $16 \mathrm{~h}$. Neste procedimento, só são capazes de crescer bactérias que contenham o vetor recombinado, uma vez que este apresenta o gene de resistência à canamicina como seletor. Os clones foram selecionados, cultivados em meio líquido LB e utilizados para a extração dos plasmídeos. Os plasmídeos recombinantes foram utilizados como molde em PCR para a verificação da presença do inserto, utilizando-se primers T7 (forward e reverse), para amplificação das extremidades dos genes e primers específicos dos genes de interesse, para amplificação da região interna dos genes (Tabelas VI e VII). Os plasmídeos foram sequenciados para confirmação das sequências e verificar se os genes de interesse estavam na pauta correta de leitura.

Tabela VII: Sequência de primers utilizados na PCR de sequenciamento

\begin{tabular}{|c|c|}
\hline Nome & Sequência (5'-3') \\
\hline T7 FWD & TAATACGACTCACTATAGGG \\
\hline T7 REV & GCTAGTTATTGCTCAGCGG \\
\hline Hex 110 0R & CTCGTGAATCCAAGTGATGT \\
\hline Hex $1101 \mathrm{~F}$ & GTTGCTGCTGTATTAACTCG \\
\hline Hex 110 1R & CAGTTCCTTCAATCAGATCAC \\
\hline Hex $1102 \mathrm{~F}$ & GTCCTCAGAATCTTCAACTTC \\
\hline Hex $1102 \mathrm{R}$ & ATGGTCGTGTTTGGGTCCAA \\
\hline Hex $1103 F$ & TACTGGTCACCAATCCCAAC \\
\hline Hex $1103 R$ & TGGCCTACAGGATTCTGGAT \\
\hline Hex $1104 \mathrm{~F}$ & GGCGGAGGAATTCAGCAAAA \\
\hline Hex $1104 \mathrm{R}$ & CATAGGGGACGTTCATTCCT \\
\hline Hex $1105 F$ & TCCGTACTGCAAGGATTAGG \\
\hline Hex 70a 1R & ATCAGAGCGTGATTGGCTTT \\
\hline Hex $70 \mathrm{a} 2 \mathrm{~F}$ & СТСТCTGGGCGAAGAACAAC \\
\hline Hex 70a 2R & ACCAGAATCGATTGCTGCCG \\
\hline Hex 70a $3 F$ & GAGAATATCGGCAGCAATCG \\
\hline Hex 70a 3R & CAGTTTGTGATGCGAATCGT \\
\hline Hex 70a 4F & TGAAGAGCAAAGAAACGATGA \\
\hline Hex 70c $1 R$ & GGGATAGATCTCGTAGATGG \\
\hline Hex $70 \mathrm{c} 2 \mathrm{~F}$ & TTACAAAACTGCCGCTTGGG \\
\hline Hex 70c 2R & ATCCAGAATTGATGGGCTTG \\
\hline Hex 70c $3 F$ & GCCCAAAGAAATACGTGGAC \\
\hline Hex 70b F & ATCCGCTCTTCAAATGTGGTCTAC \\
\hline Hex 70b R & GTGTTGCTTCCGCTTTTCAGG \\
\hline
\end{tabular}




\subsubsection{Preparo das células competentes E. coli de linhagens DH5a e BL21}

As linhagens DH5 $\alpha$ e BL21 de E. coli estocadas a $-70^{\circ} \mathrm{C}$ foram inoculadas em $5 \mathrm{~mL}$ de meio $\mathrm{LB}$ a $37^{\circ} \mathrm{C}$ e $180 \mathrm{rpm}$ por cerca de $16 \mathrm{~h}$. Uma fração de $200 \mu \mathrm{L}$ deste cultivo líquido foi utilizado para inocular $50 \mathrm{~mL}$ de meio $\mathrm{LB}$ a $37^{\circ} \mathrm{C}$ sob agitação a $230 \mathrm{rpm}$ até atingir densidade óptica (D.O.) de 0,5 - 0,6 em comprimento de onda de $600 \mathrm{~nm}$. As células foram mantidas em gelo por 30 min e centrifugadas a $5000 \mathrm{rpm}$ (Eppendorf $5415 \mathrm{R}$ ) por $5 \mathrm{~min}$ a $4^{\circ} \mathrm{C}$.

Para as células utilizadas para transformação por choque térmico, o precipitado foi ressuspendido cuidadosamente em $5 \mathrm{~mL}$ de $\mathrm{CaCl}_{2} \quad 0,1 \mathrm{M}$ e submetido a uma nova centrifugação de $5000 \mathrm{rpm}$ (Eppendorf $5415 \mathrm{R}$ ) por $5 \mathrm{~min}$ a $4^{\circ} \mathrm{C}$. O precipitado foi ressuspendido cuidadosamente em $5 \mathrm{~mL}$ de $\mathrm{CaCl}_{2}$,, $1 \mathrm{M}$ acrescido de glicerol (15\%), aliquotado $\left(250 \mu \mathrm{L}\right.$ por tubo) e estocado à $-70^{\circ} \mathrm{C}$. Já para as bactérias utilizadas para transformação por eletroporação, o precipitado foi ressuspendido cuidadosamente em $5 \mathrm{~mL}$ de água milli-Q e submetido a uma nova centrifugação de $5000 \mathrm{rpm}$ (Eppendorf $5415 \mathrm{R}$ ) por 5 min a $4^{\circ} \mathrm{C}$. O precipitado foi ressuspendido cuidadosamente em glicerol $(80 \%)$, aliquotado $\left(250 \mu \mathrm{L}\right.$ por tubo) e estocado à $-70^{\circ} \mathrm{C}$.

\subsubsection{Sequenciamento}

O sequenciamento foi realizado pelo método de Sanger utilizando reação com big dye (Perkin Elmer). Nestas reações foram usados $2 \mu \mathrm{L}$ de big dye, $2 \mu \mathrm{L}$ de tampão de seqüenciamento, $2 \mu \mathrm{L}$ de plasmídio com os insertos, $3 \mu \mathrm{L}$ de água estéril e $1 \mu \mathrm{L}$ de primer foward ou $1 \mu \mathrm{L}$ de primer reverse (Tabelas VI e VII), resultando em um volume final de 10 $\mu \mathrm{L}$ de reação. As amplificações ocorreram em 25 ciclos de $96^{\circ} \mathrm{C}-10 \mathrm{~s}, 50^{\circ} \mathrm{C}-5 \mathrm{~s}$ e $60^{\circ} \mathrm{C}-4$ min. Os produtos das reações para hex $70 b$ foram precipitados por isopropanol $75 \%$, ressuspendidos em Hi-dye Formamide (Applied Biosystems), desnaturados a $94^{\circ} \mathrm{C}$ por 2 min e submetidos a eletroforese capilar em aparelho ABI Prism ${ }^{\mathrm{TM}} 310$ Genetic Analyzer (Applied Biosystems). Os produtos das reações para hex 110, hex 70a e hex 70c foram purificados em Sephadex (Illustra ${ }^{\mathrm{TM}}$ Sephadex ${ }^{\mathrm{TM}}$ G-50 Fine DNA Grade, GE Healthcare) com colunas Multiscreen HV (Millipore) e centrifugação a $2300 \mathrm{rpm}$ (Eppendorf $5810 \mathrm{R}$ ) por $5 \mathrm{~min}$. Os produtos purificados foram aquecidos a $95^{\circ} \mathrm{C}$ por aproximadamente $15 \mathrm{~min}$ até secagem total. Os produtos das reações foram ressuspendidos em Hi-dye Formamide, desnaturados a $94^{\circ} \mathrm{C}$ por 2 min e submetidos à eletroforese capilar em aparelho ABI 3730 DNA Analyser (Applied Biosystems). As sequências obtidas foram analisadas por meio do programa Sequencher TM version 4.7 for Windows (Gene Codes Corporation) que avalia as sequências pela qualidade 
dos eletroferogramas gerados pelo seqüenciador, com posterior anotação destas sequências no genoma, com o auxílio da plataforma Artemis 7.0 (Rutherford et al. 2000).

\subsubsection{Preparo das linhagens de expressão}

Os plasmídeos de expressão contendo os genes de interesse foram utilizados para transformar células competentes de E.coli da linhagem de expressão BL21, do mesmo modo descrito no item 8.11.3 para as bactérias E. coli da linhagem DH5

\subsubsection{Produção das proteínas}

Os clones foram pré-inoculados em LB líquido contendo $15 \mu \mathrm{g} / \mu \mathrm{L}$ de canamicina e incubados overnight a $37^{\circ} \mathrm{C}$ e $170 \mathrm{rpm}$ de agitação. Os pré-inóculos foram quantificados a $600 \mathrm{~nm}$ e utilizados para inocular $100 \mathrm{~mL}$ de meio LB contendo canamicina, de forma a se obter uma DO inicial de 0,2 . Os meios foram incubados a $37^{\circ} \mathrm{C}$ e $170 \mathrm{rpm}$ até atingir uma DO entre 0,6 e 0,8 . Neste momento, $1 \mathrm{mM}$ de IPTG foi adicionado aos meios de cultivo que foram deixados a $37^{\circ} \mathrm{C}, 170 \mathrm{rpm}$, por $3 \mathrm{~h}$. Os meios foram centrifugados a $5000 \mathrm{rpm}$ (Eppendorf $5415 \mathrm{R}$ ) por $10 \mathrm{~min}$. Os pellets obtidos foram lavados em água milli-Q e centrifugados novamente a $5000 \mathrm{rpm}$ (Eppendorf $5415 \mathrm{R}$ ) por $10 \mathrm{~min}$. Os sobrenadantes foram descartados e os pellets foram estocados a $-20^{\circ} \mathrm{C}$ até o momento de uso.

\subsubsection{Purificação das proteínas}

Os pellets foram ressuspendidos em $15 \mathrm{~mL}$ de start buffer [10 $\mathrm{mL}$ de tampão fosfato $200 \mathrm{mM}(19 \mathrm{~mL}$ de fosfato de sódio monobásico $0,2 \mathrm{M} ; 81 \mathrm{~mL}$ de fosfato de sódio dibásico 0,2 M; água milli-Q para um volume final de $200 \mathrm{~mL}, \mathrm{pH} 7,4), 12,5 \mathrm{~mL}$ de $\mathrm{NaCl} 4 \mathrm{M}, 1 \mathrm{~mL}$ de imidazol 2M, água milli-Q até completar o volume para $100 \mathrm{~mL}$ ] e $300 \mu \mathrm{L}$ de inibidor de protease $50 \mathrm{mM}$. A solução obtida foi sonicada, a $4^{\circ} \mathrm{C}$, com $30 \%$ de amplitude em 4 ciclos de $30 \mathrm{~s}$ de homogeneização com a macroponta e $30 \mathrm{~s}$ de repouso, seguidos de 16 ciclos com a microponta. $\mathrm{O}$ homogeneizado foi incubado com estreptomicina $10 \%$, sob agitação, a $4^{\circ} \mathrm{C}$, por $20 \mathrm{~min}$, e centrifugado a $15000 \mathrm{rpm}$ (Eppendorf $5415 \mathrm{R}$ ), por $45 \mathrm{~min}$. O sobrenadante obtido foi filtrado em Millex ${ }^{\circledR G P}$ de $0,22 \mu \mathrm{m}$ (Millipore). O pellet foi ressuspendido em 1 $\mathrm{mL}$ de água milli-Q. Com o auxílio de uma coluna HiTrap ${ }^{\mathrm{TM}}$ Chelating HP (GE Healthcare) de $1 \mathrm{~mL}$, as proteínas presentes no filtrado foram purificadas e submetidas a gel SDS-PAGE 9\%, juntamente com uma alíquota do pellet que foi ressuspendido, para confirmação da expressão das proteínas e sua solubilidade. Os géis foram corados com Coomassie R-250. 


\section{Resultados}

\section{I - Aspectos da multifuncionalidade das hexamerinas}

\section{Dinâmica do acúmulo das subunidades de hexamerinas no corpo gorduroso e hemolinfa durante o desenvolvimento}

A expressão das 4 hexamerinas na hemolinfa e no corpo gorduroso foi analisada por western blots em pontos críticos do desenvolvimento (Fig. 4). Ficou evidente a existência de grandes quantidades de todas as hexamerinas na hemolinfa de larvas L5F quando comparada ao corpo gorduroso na mesma fase do desenvolvimento, sugerindo fortemente intensa secreção destas proteínas para a hemolinfa. Nas fases seguintes, L5S e PP, a abundância de todas as hexamerinas aumenta no corpo gorduroso. De tudo o que se sabe sobre o intercâmbio das hexamerinas entre o corpo gorduroso e a hemolinfa, este aumento denota que elas estão retornando para o corpo gorduroso via sequestro da hemolinfa. Da fase L5S para as fases de adultos faratos $(\mathrm{Pb}, \mathrm{Pbm})$, as hexamerinas permanecem relativamente abundantes no corpo gorduroso (sendo a HEX 110 a menos abundante). Exceto para a HEX 70a, a abundância de todas as hexamerinas no corpo gorduroso diminui para níveis indetectáveis antes da ecdise adulta. HEX 70a é a única que está presente na hemolinfa das operárias adultas, inclusive nas forrageiras. O padrão de diminuição de HEX 70b, HEX 70c e HEX 110 na hemolinfa é consistente com a função de reserva de aminoácidos para o desenvolvimento pupal e adulto farato. 


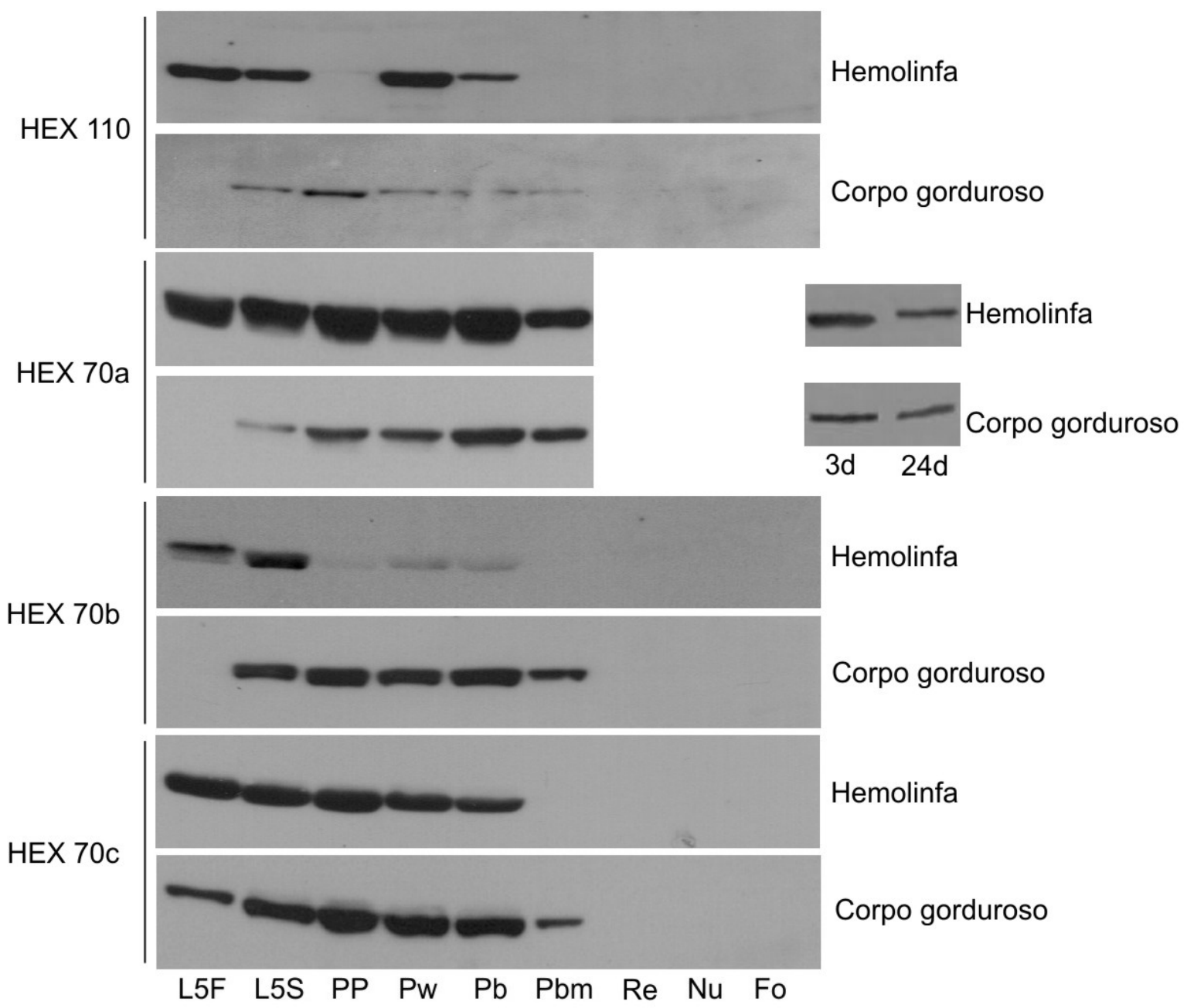

Figura 4: Análise por western blot das hexamerinas da hemolinfa e corpo gorduroso durante o desenvolvimento de operárias. L5F e L5S: fases de alimentação e de tecelagem do casulo de larvas do $5^{\circ}$ instar. PP: pupas faratas. $\mathrm{Pw}$ : pupas. $\mathrm{Pb}$, Pbm: fases sucessivas de adultas faratas. Re: adulta recém-emergida. Nu: nutridoras. Fo: forrageiras. $\mathrm{O}$ western blot relativo à hexamerina HEX 70a de operárias adultas com 3 e 24 dias de idade foi extraído de Martins et al. (2008).

\section{Detecção das hexamerinas no núcleo das células do corpo gorduroso}

É de conhecimento geral que as hexamerinas se acumulam em grânulos no citoplasma das células do corpo gorduroso. Aqui investigamos se estas proteínas estariam também presentes em extratos de núcleos. Todas as hexamerinas foram detectadas na fração nuclear obtida do corpo gorduroso, como demonstrado por SDS-PAGE e western blot usando anticorpos específicos (Fig. 5). 


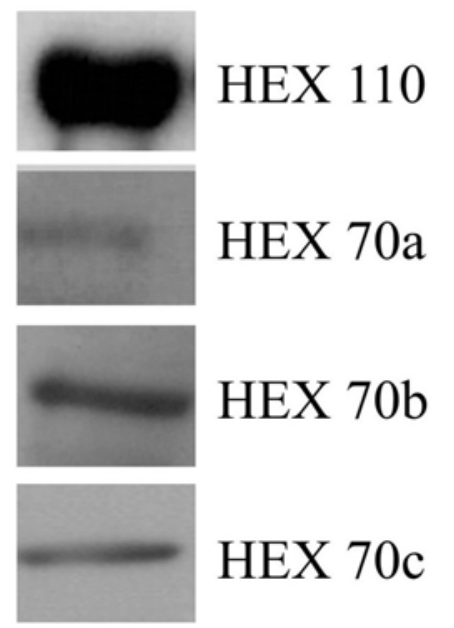

Figura 5: Hexamerinas detectadas por western blot em extratos enriquecidos de núcleos de células do corpo gorduroso

\section{Imunolocalização das hexamerinas no citoplasma e no núcleo das células do corpo gorduroso}

A utilização de anticorpos específicos e microscopia confocal permitiu localizar as hexamerinas nos trofócitos e enócitos do corpo gorduroso.

Nos trofócitos, HEX 110 (Fig. 6A-C), HEX 70a (Fig. 6D-F), HEX 70b (Fig. 6G-I) e HEX 70c (Fig. 6J-L) localizam-se no núcleo e citoplasma. A localização nuclear de HEX 110 (Fig. 6A, C) e HEX 70a (Fig. 6D, F) foi mais evidente do que a localização nuclear de HEX 70 b (Fig. 6J, L). As quatro hexamerinas localizam-se como densos grânulos de diferentes tamanhos, ou como grandes inclusões citoplasmáticas Nos trofócitos mostrados na Fig. 6G, HEX 70b localiza-se na superfície celular. De forma peculiar, os trofócitos incubados com anti-HEX 70b (Fig. 6G) e anti-HEX 70c (Fig. 6J) mostram grandes grânulos de diferentes densidades próximos à superfície celular, sugerindo que são derivados da endocitose das hexamerinas.

Uma profusão de inclusões (em vermelho) foi observada no citoplasma dos trofócitos corados com iodeto de propídeo (Fig. 6B, E, H, K e suas respectivas sobreposições 6C, F, I, L). Iodeto de propídeo é um corante comumente utilizado para marcação do DNA nuclear, mas também se liga ao RNA. As inclusões no citoplasma dos trofócitos, marcada em vermelho por iodeto de propídeo, aparentemente são vacúolos autofágicos contendo DNA e RNA ribossomal, produtos remanecentes de mitocôndrias e da reciclagem de retículo endoplasmático rugoso (RER). As inclusões em vermelho no citoplasma dos trofócitos (Fig. 6B, E, H e K) também são caracterizadas pela presença de uma região central sem marcação. 
Figura 6: Microscopia confocal para localização das hexamerinas nos trofócitos de pupas faratas (PP). Trofócitos marcados com Alexa Fluor 488: preparações utilizando-se (A) anti-HEX 110, (D) anti-HEX 70a, (G) anti-HEX 70b e (J) anti-HEX 70c para detecção das respectivas hexamerinas (marcação em verde). (B, E, H, K) Núcleos corados com iodeto de propídeo (vermelho). Na coluna da direita as imagens sobrepostas mostram: (C) HEX 110, (F) HEX 70a, (I) HEX 70b e (L) HEX 70c nos núcleos (amarelo) e no citoplasma (verde). As pontas de setas maiores mostram a localização nuclear das hexamerinas. As pontas de setas menores mostram hexamerinas em pequenos grânulos próximos da superfície celular. As setas maiores mostram hexamerinas em grandes grânulos citoplasmáticos. As setas menores mostram hexamerinas em pequenos grânulos citoplasmáticos. A célula no centro das Figuras $\mathbf{J}, \mathbf{K}$ e $\mathbf{L}$ é um enócito. 


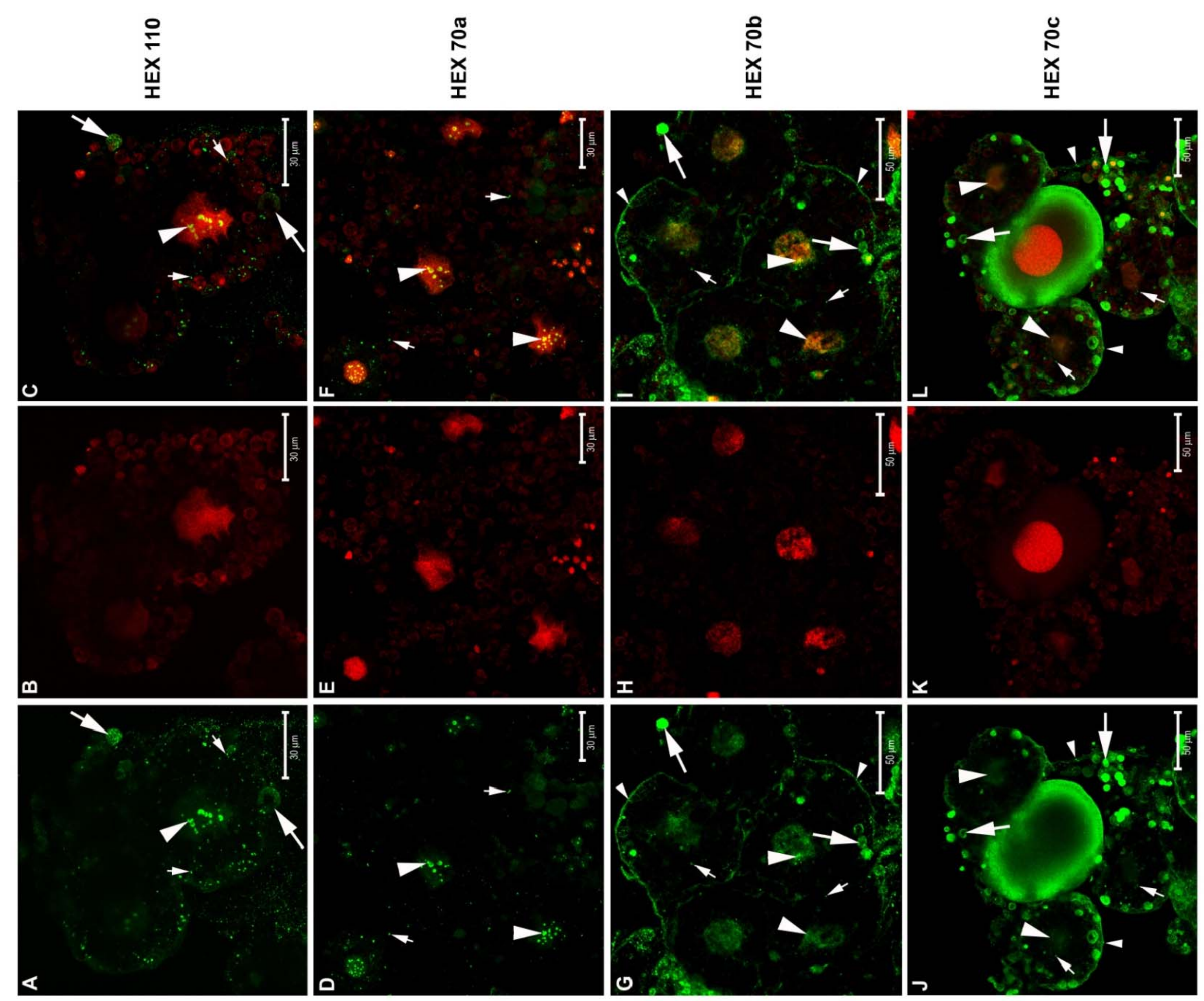


Hexamerinas também foram localizadas nos enócitos (Fig. 7A-O). A Fig. 7A-C mostra preparações de enócitos sem o anticorpo específico (primário), as quais constituem os controle do procedimento de imunolocalização, que também servem de controles para as preparações da Fig. 6. Os padrões de imunolocalização de HEX 110 (Fig. 7D-F) e HEX 70a (Fig. 7G-I) são similares: estão presentes no núcleo e também dispersas no citoplasma. Marcação para as outras duas hexamerinas, HEX 70b (Fig. 7J-L) e HEX 70c (Fig. 7M-O) foi observada exclusivamente no citoplasma dos enócitos, e a localização de HEX 70c está limitada ao citoplasma periférico. 
Figura 7: Microscopia confocal para a localização das hexamerinas nos enócitos de pupas faratas (PP). Enócitos marcados com Alexa Fluor 488: preparações (A) sem o anticorpo primário específico (controle) ou com (D) antiHEX 110, (G) anti-HEX 70a, (J) anti-HEX 70b ou (M) anti-HEX 70c para a localização das respectivas hexamerinas (marcação em verde). (B, E, H, K, N) Núcleos corados com iodeto de propídeo (vermelho). Na coluna da direita as imagens sobrepostas mostram: (C) controle sem o anticorpo, (F) HEX 110 e (I) HEX 70a nos núcleos (amarelo) e no citoplasma (verde), (L) HEX 70b no citoplasma (verde), (O) HEX 70c na periferia do citoplasma (verde). As pontas de setas mostram a localização nuclear e as setas mostram a localização citoplasmática das hexamerinas. 


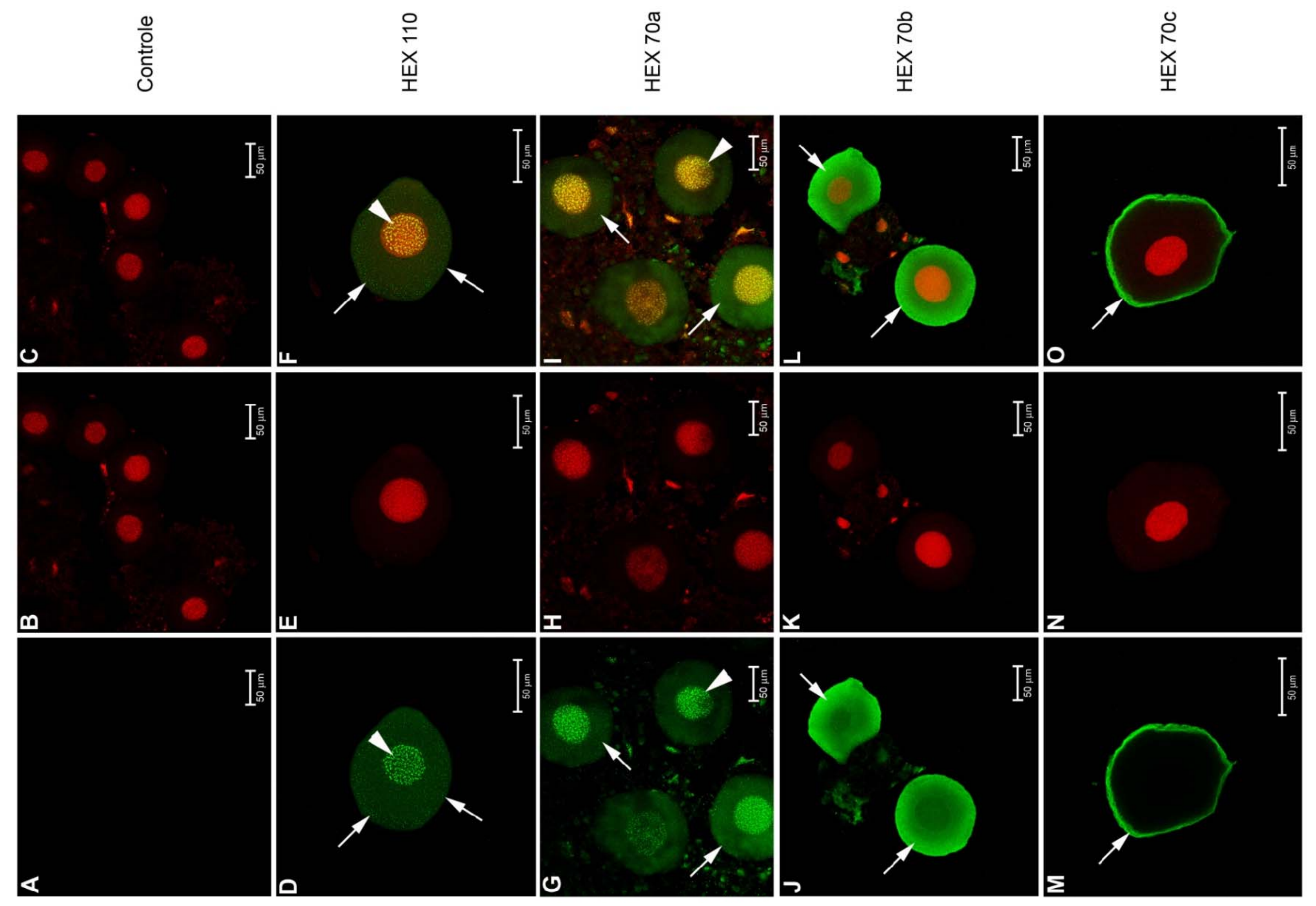




\section{Hexamerinas nas gônadas}

\subsection{Imunolocalização da HEX 70a no núcleo das células ovarianas de operárias adultas- faratas}

O estudo dos ovários de operárias adultas faratas foi realizado a partir de cortes histológicos corados com azul de metileno e fucsina básica (Fig. 8A), e visualização de ovaríolos inteiros, por microscopia confocal, através da marcação de F-actina com rodamina/faloidina (Fig. 8B, C). A hexamerina HEX 70a foi localizada por imunodetecção com anti-HEX70a/Cy3 (Fig. 8E, F). DAPI foi utilizado para marcar os núcleos das células ovarianas e facilitar a visualização dos ovaríolos (Fig. 8B, C, D, F). No estágio inicial do desenvolvimento do adulto farato (1 dia após a ecdise pupal), cada ovaríolo consiste de um filamento terminal (não mostrado) e um germário proximal. No germário, as células da linhagem germinativa, ou cistócitos, estão começando a ser arranjadas em estruturas denominadas rosetas (uma delas marcada com uma circunferência na Fig. 8A). Cada roseta é um clone formado por vários cistócitos derivados de um único cistoblasto (ovogônia) e dará origem a um único ovócito e aos trofócitos que o acompanham, ou células nutridoras. Para melhor visualizar a estrutura do ovaríolo neste estágio do desenvolvimento, foi utilizada rodamina/faloidina para detectar a F-actina, e DAPI para marcar os núcleos das células ovarianas. Na região proximal do germário (parte superior da Fig. 8B) pode-se visualizar um denso complexo de actina, típico da região do polifusoma no centro de cada roseta de cistócitos (pontas de seta na Fig. 8B). Na região mais distal do germário (parte inferior da Fig.

8B, C) os polifusomas foram convertidos em canais em anel (setas nas Fig. 8B, C) que permitem a comunicação entre as células da linhagem germinativa, i.e., entre as células destinadas a serem ovócitos e as células nutridoras associadas. Ovaríolos com estas características estruturais, como detalhado nas Fig. 8A-C, foram preparados para a detecção da hexamerina HEX 70a com anti-HEX 70a/Cy3. A Fig. 8D mostra uma região proximal do germário de um ovaríolo marcado com DAPI. A Fig. 8E ilustra a mesma região do ovaríolo onde a marcação da HEX 70a pode ser visualizada (uma sobreposição das imagens é mostrada na Fig. 8F). O inserto na Fig. 8F representa um ovaríolo controle incubado com soro pré-imune e corado com DAPI e Cy3. Comparações entre as Fig. 8D-F revelam que a HEX 70a está localizada no núcleo das células germinativas (cistócitos), aparentemente em associação com a cromatina (pontas de seta nas Fig. 8D-F). As células foliculares (células somáticas) presuntivas não estão muito evidentes neste estágio, mas foram indicadas por setas 
nas Fig. 8D-F. Assim como os núcleos das células germinativas, os núcleos das células somáticas mostram marcação para a HEX 70a. 
Figura 8: Detecção da HEX 70a nos ovaríolos de operárias no início do desenvolvimento adulto farato (1 dia após a ecdise pupal, o estágio de desenvolvimento está ilustrado na região superior esquerda da figura). (A) Microscopia de luz dos ovaríolos (cobertos por suas respectivas bainhas peritoneais) corados com azul de metileno e fucsina básica. Somente o germário está representado na figura (a região mais anterior do ovaríolo, ou filamento terminal, não é mostrada). Uma roseta formada por células da linhagem germinativa (precursoras dos ovócitos e células nutridoras) é ressaltada por uma circunferência no germário. (B, $\mathbf{C})$ Imagens de microscopia confocal com marcação da F-actina por rodamina/faloidina (verde) e núcleos das células marcados com DAPI (azul) mostram aspectos estruturais dos ovaríolos (a bainha peritoneal foi removida). Os polifusomas ricos em actina (pontas de seta em B) são visualizados no centro das rosetas de cistócitos na região proximal do germário. Canais em anel derivados dos polifusomas (setas em B e C) estão aparentes na região distal do germário mostrado em B e em um maior aumento em C. (D) Microscopia confocal de um ovaríolo (porção proximal do germário) marcado com DAPI. (E) HEX 70a detectada com anti-HEX 70a/Cy3 (vermelho). (F) Sobreposição das imagens D e E. O inserto em F mostra um ovaríolo "controle” (porção proximal do germário) incubado com soro pré-imune e subsequentemente marcado com Cy3/DAPI. Pontas de seta em D-F mostram os núcleos das células de linhagem germinativa. Setas em D-F apontam para os núcleos dos precursores das células foliculares. Em todas as figuras, a porção proximal do germário está orientada para cima. 


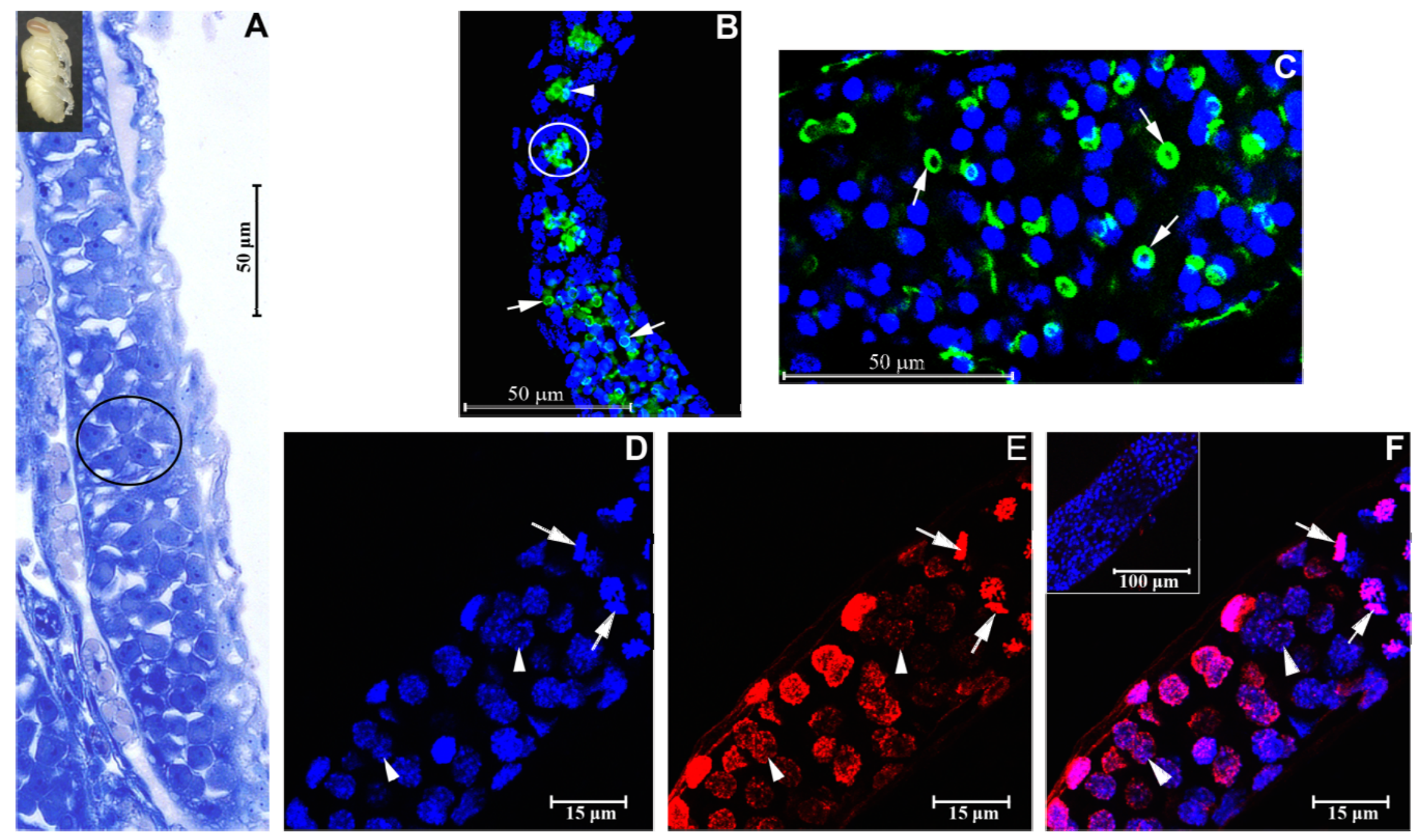




\subsection{Imunolocalização de HEX 70a nos ovaríolos de rainhas ovipositoras}

HEX 70a também foi localizada nos ovaríolos de rainhas adultas. A Fig. 9A mostra uma representação esquemática de um ovaríolo de rainha ovipositora. O ovaríolo consiste de uma estreita região distal, o filamento terminal, uma região intermediária, ou germário, e uma região proximal, o vitelário. O filamento terminal contém células somáticas e putativas células-tronco de linhagem germinativa (Tanaka e Hartfelder, 2004). Os aglomerados de cistócitos são observados na região proximal do germário, e na região distal é possível visualizar os ovócitos em crescimento associados com as células nutridoras poliplóides. $\mathrm{Na}$ região proximal do vitelário (Fig. 9A), são visíveis as câmaras de células nutridoras e do ovócito formando os folículos pré-vitelogênicos. A região basal do vitelário é a maior região do ovaríolo (Fig. 9B) e consiste de uma sequência de ovócitos em crescimento envolvidos por uma camada de células foliculares (pontas de seta), e intercalados com câmaras de células nutridoras (setas). Nesta região, os ovócitos atingem o máximo de seu tamanho, as células nutridoras entram em colapso, o córion é formado e o ovo é finalmente liberado no oviduto.

As Fig. 9C-K mostram a localização de HEX 70a nos ovaríolos. Na região distal do filamento terminal (Fig. 9C-E), HEX 70a está fortemente associada aos núcleos das células, mas também se localiza no citoplasma das células do filamento (Fig. 9D, E, setas). HEX 70a também foi localizada nos núcleos das células nutridoras (Fig. 9F-H) e das células foliculares (Fig. 9I-K), que recobrem o ovócito. Em ambos os tipos celulares, HEX 70a é exclusivamente intranuclear. Os foci de HEX 70a assemelham-se a pontos pequenos e são distribuídos por todo o núcleo das células nutridoras poliplóides e são maiores e concentrados em áreas nucleares bem definidas nas células foliculares em proliferação. 
Figura 9: Imunolocalização de HEX 70a nos ovaríolos de rainhas ovipositoras. (A) Representação esquemática de um ovaríolo de rainha ovipositora (mostrada na margem esquerda superior): somente o filamento terminal, o germário e os folículos pré-vitelogênicos na região proximal do vitelário são mostrados em A. Imagens de microscopia confocal: (B) Parte de um ovaríolo mostrando as regiões intermediária e distal do vitelário marcado com rodamina/faloidina (verde) para visualização da F-actina. As setas e pontas de seta mostram o desenvolvimento das câmaras de células nutridoras e de ovócitos, respectivamente. (C-E) O filamento terminal (a região distal está orientada para baixo) comtém HEX 70a nos núcleos de suas células (D, E) e no citoplasma (setas em D, E). (F-H) Núcleos das células nutridoras (região distal do vitelário como indicado pelas setas em B). (I-K) Núcleos das células foliculares que recobrem um ovócito na região distal do vitelário (como indicado pelas pontas de seta em B). (C, F, I) Núcleos das células marcados com DAPI (azul); (D, G, J) Marcação com anti-HEX 70a/Cy3 para detecção de HEX 70a (vermelho) e (E, H, K) sobreposição das imagens. 


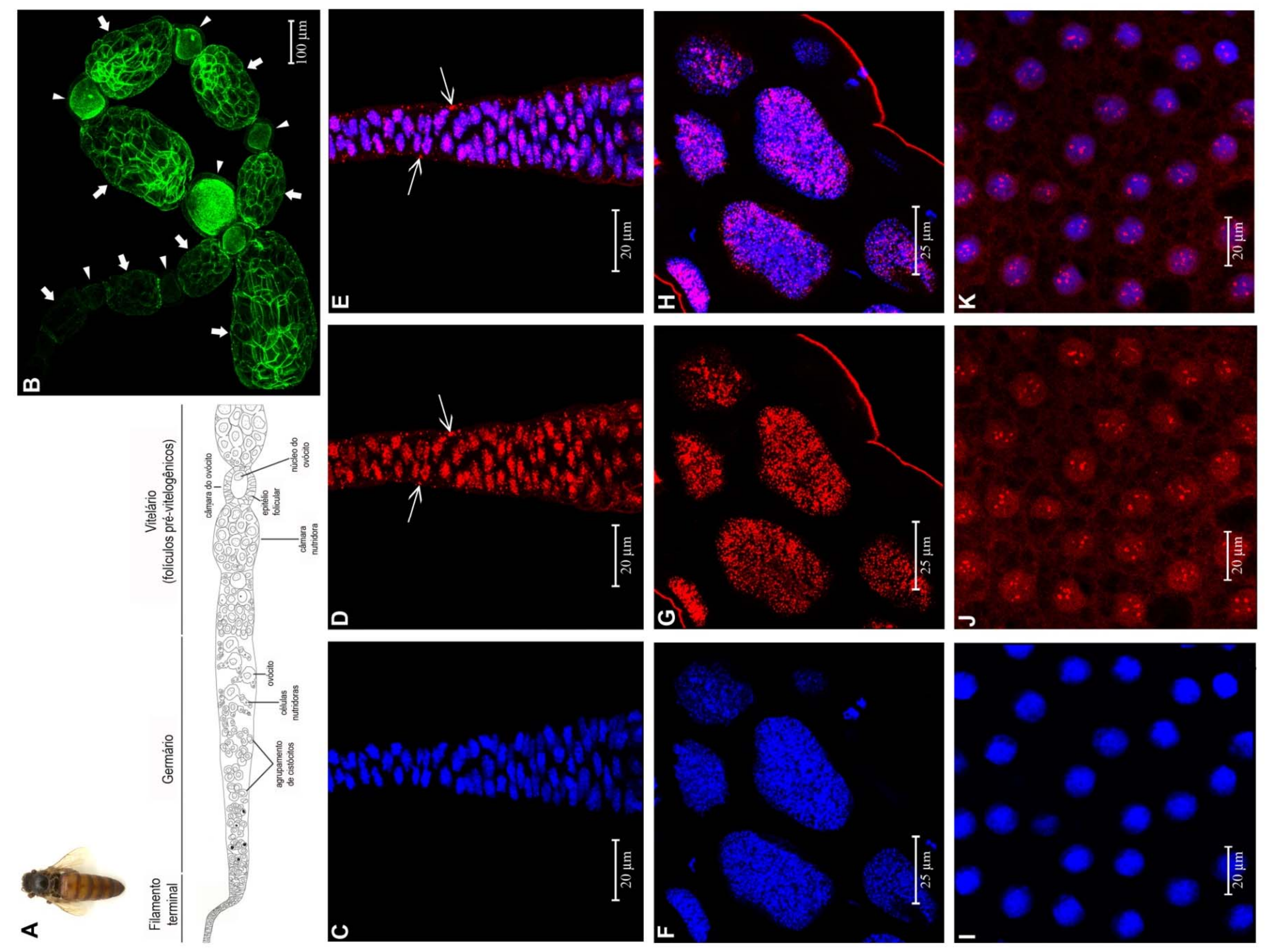




\subsection{Imunolocalização da hexamerina HEX 110 em ovários de operárias adultas e rainhas ovipositoras}

Em ovários de operárias adultas (Fig. 10), com aproximadamente 7 dias de idade, marcados com anti-HEX 110/Alexa Fluor 488 (verde) foi possível detectar HEX 110 nos núcleos (setas) da região proximal do filamento terminal (Fig. 10A, B e C) e da região distal do germário (Fig. 10D, E e F). Em ambas regiões, os foci nucleares de HEX 110 foram visualizados tanto nas células germinativas quanto nas células somáticas. HEX 110 também se localiza no citoplasma das células do filamento terminal e do germário (pontas de seta) (Fig. 10A-F). Na região pré-vitelogênica (Fig. 10G, H, I), a hexamerina HEX 110 está presente no núcleo das células foliculares e no citoplasma tanto das células somáticas quanto das germinativas. 
Figura 10: Detecção de HEX 110 nos ovários de operárias adultas com 7 dias de idade (estágio do desenvolvimento mostrado na margem esquerda superior). (A, B, C) Filamento terminal (a região distal está orientada para baixo). (D-F) Porção proximal do germário. (G-I) Porção distal do germário. (A, D, G) Núcleos das células marcados com iodeto de propídeo (vermelho); (B, E, H) Marcação com anti-HEX 110/Alexa Fluor 488 para detecção de HEX 110 (verde) e (C, F, I) sobreposição ds imagens. Setas indicam a marcação nuclear. Pontas de seta indicam marcação citoplasmática. 


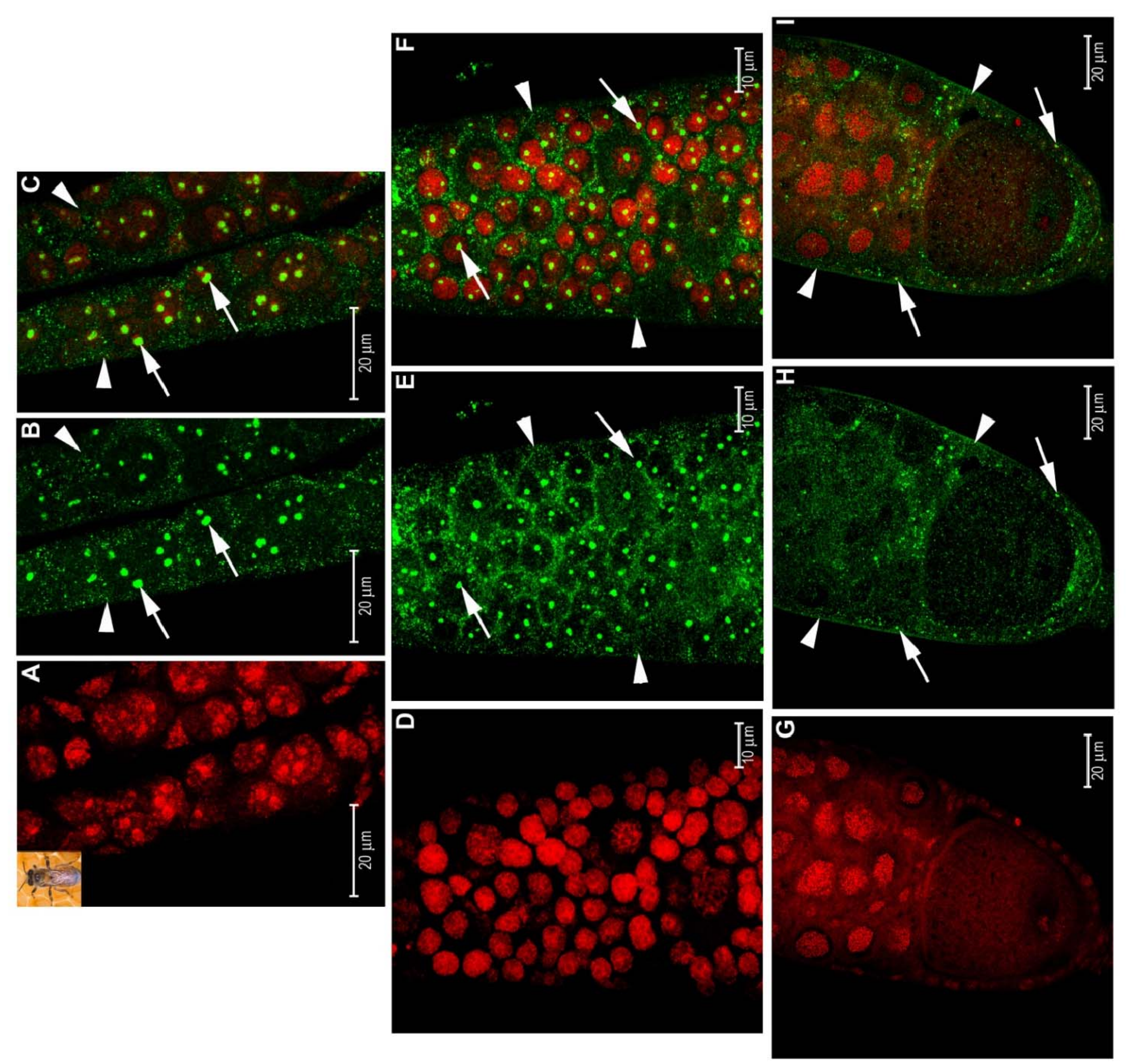


Em rainhas ovipositoras, a localização da hexamerina HEX 110 é peculiar às regiões do ovaríolo (Fig. 11). As preparações dos controles (Fig. 11A, B e C), não incubados com o anticorpo primário, demonstram a especificidade da marcação, uma vez que nenhum sinal de fluorescência foi observado. Nas regiões proximal do filamento terminal e do germário, a hexamerina HEX 110 tem localização intranuclear e citoplasmática (Fig. 11D, E e F). Isto não foi observado na região do vitelário, uma vez que nas câmaras nutridoras, apenas os núcleos proximais apresentam marcação para HEX 110 (Fig. 11G, H e I). No folículo em desenvolvimento (Fig. 11J, K e L) e no folículo maduro (Fig. 11M, N e O), a HEX 110 se localiza no citoplasma das células foliculares. 
Figura 11: Imunolocalização de HEX 110 nos ovários de rainhas ovipositoras. (A, B, C) Preparações controles. Parte do vitelário de um ovaríolo preparado sem o anticorpo anti-HEX 110. (D-F) Filamento terminal (a região distal está orientada para baixo). (G-I) Câmara nutridora (no meio da figura) e folículo ovariano (embaixo) (região distal do vitelário). (J-L) Folículo ovariano formado pelo grande ovócito envolvido por células foliculares. Região intermediária do vitelário. (M-O) Parte de um folículo maduro. (A, D, G, J, M) Núcleos das células marcados com iodeto de propídeo (vermelho); (B, E, H, K, N) Marcação com anti-HEX 110/Alexa Fluor 488 para deteç̧ão de HEX 110 (verde) e $(\mathbf{C}, \mathbf{F}, \mathbf{I}, \mathbf{L}, \mathbf{O})$ sobreposição das imagens. Setas indicam marcação nuclear. Pontas de seta indicam marcação citoplasmática. 


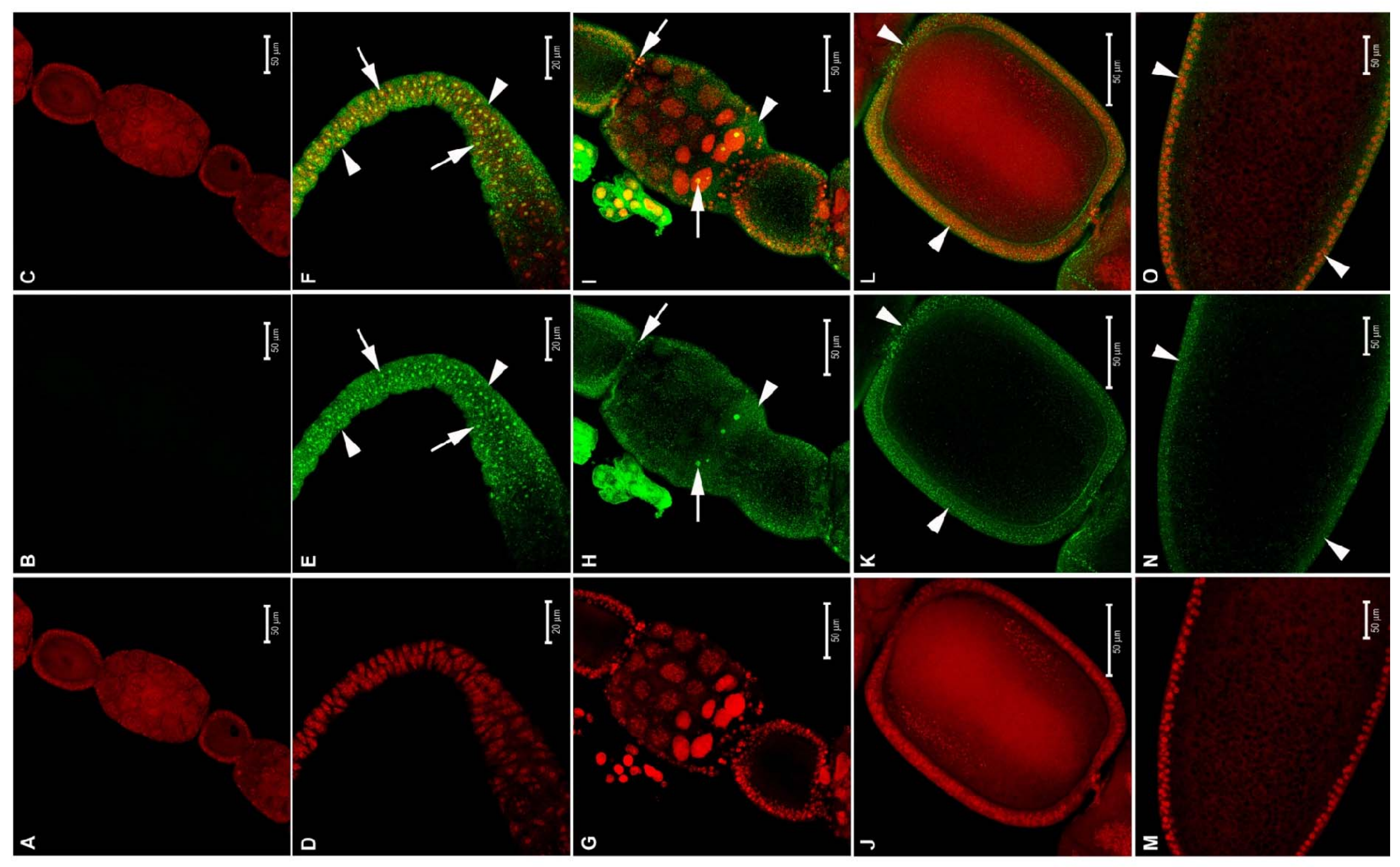




\subsection{Imunolocalização de HEX 70a nos testículos}

HEX 70a também foi detectada nas células somáticas e germinativas dos testículos em desenvolvimento. A Fig. 12A mostra uma secção da porção proximal de um testíolo dissecado de uma pupa de zangão (1 dia após a ecdise pupal). Nesta região pode-se observar os cistos, i.e., grupos de células germinativas (cistócitos ou espermatogônia: setas na Fig. 12A) alojados no interior de um envelope de células somáticas (os núcleos das células somáticas estão apontados por pontas de seta na Fig. 12A). A marcação de F-actina com rodamina/faloidina (verde) e dos núcleos das células com DAPI (azul), seguida de análise por microscopia confocal, (Fig. 12B) destaca a estrutura desta região do testíolo. F-actina é um componente abundante no citoplasma das células somáticas e também está presente nos canais em anel (asteriscos na Fig. 12B) que permitem a comunicação entre as células germinativas. A comparação das Fig. 12C-E revelou que HEX 70a localiza-se predominantemente nos núcleos das células germinativas (setas largas na Fig. 12E) e das células somáticas (pontas de seta na Fig. 12E), mas também se encontra dispersa no citoplasma das células germinativas (setas finas na Fig. 12E). O pequeno volume do citoplasma das células somáticas prejudica a acurácia na identificação de marcação citoplasmática de HEX 70a. 
Figura 12: Imunolocalização da HEX 70a nos testíolos de pupas de zangões (1 dia após a ecdise pupal; estágio do desenvolvimento mostrado na margem esquerda superior). (A) Microscopia de luz de um testíolo corado com azul de metileno e fucsina básica mostrando uma região que contém grupos de cistócitos (espermatogônias) (setas) envolvidos por células somáticas (núcleos das células somáticas indicados por pontas de seta). (B) Imagem de microscopia confocal mostrando a marcação de F-actina com rodamina/faloidina (verde) e os núcleos das células marcados com DAPI (azul); pontas de seta mostram núcleos de células somáticas; o inserto mostra um aumento da imagem de um cisto contendo cistócitos (núcleos dos cistócitos apontados por setas) e canais em anel (asteriscos). (C-E) Imagens de microscopia confocal de um testíolo de zangão na mesma fase do desenvolvimento, mostrando (C) marcação dos núcleos das células com DAPI, (D) marcação da HEX 70a com anti-HEX 70a/Cy3 (vermelho), e (E) sobreposição das imagens C e D. Na Fig. 12E as setas largas mostram os núcleos das células germinativas, as setas finas mostram a marcação da HEX 70a no citoplasma; as pontas de seta mostram os núcleos das células somáticas. 


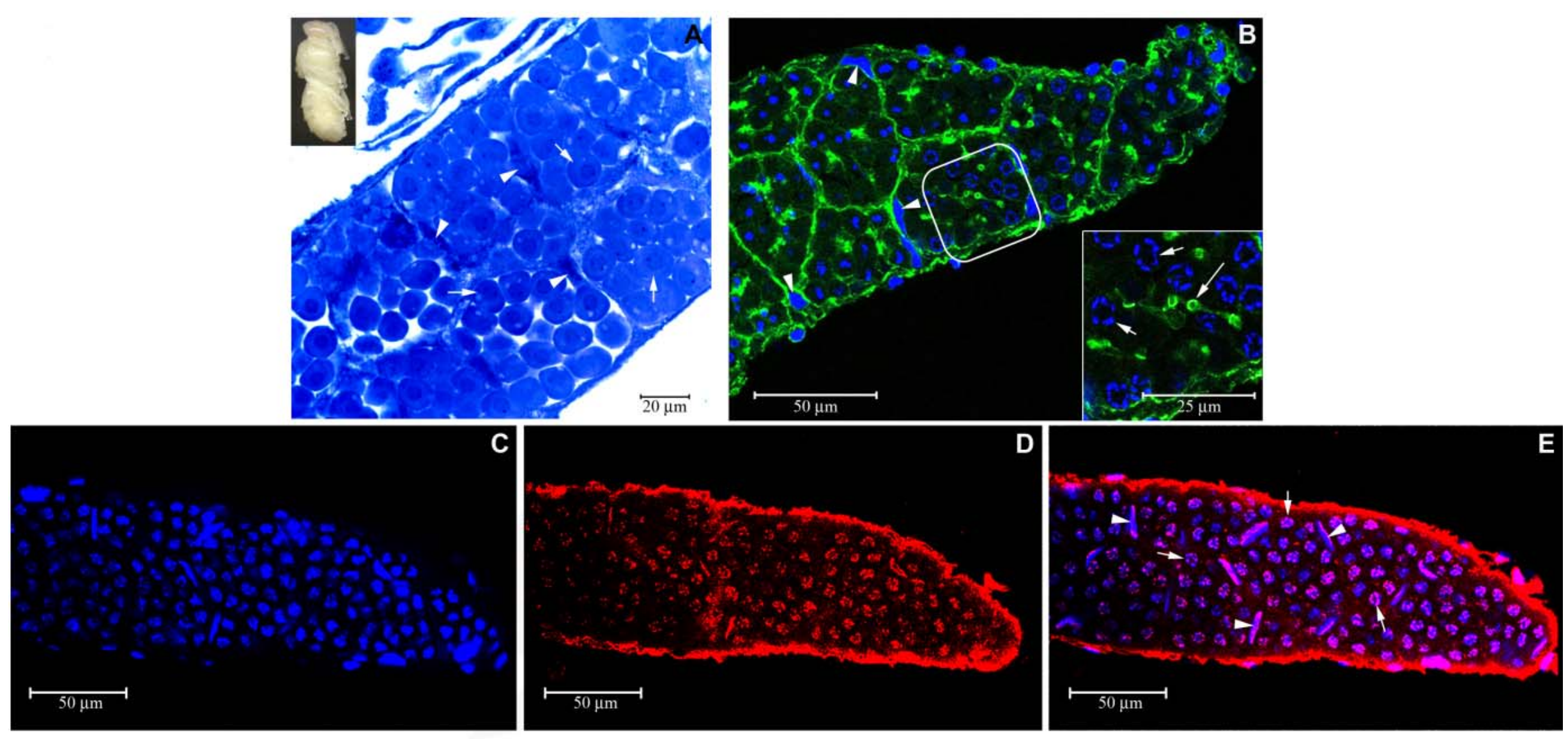


Secções das regiões distais dos testíolos de zangões em uma fase intermediária do desenvolvimento adulto farato (6 dias após a ecdise pupal) mostraram um agrupamento sincicial de espermátides alongadas (Fig. 13A, C, setas). Cones de actina são observados sobre a porção anterior dos núcleos das espermátides (Fig. 13B, D, setas). A Fig. 13E mostra os núcleos das espermátides marcados com DAPI nos agrupamentos sinciciais (setas) e os núcleos das células somáticas (pontas de seta). Na Fig. 13F, que é uma preparação marcada com anti-HEX 70a/Cy3, e na imagem sobreposta (Fig. 13G), verifica-se que HEX 70a se localiza na extremidade posterior dos núcleos das espermátides (Fig. 13F, G insertos), assim como nos núcleos dos espermatozoides individualizados (setas nas Fig. 13F, G) e das células somáticas (pontas de seta nas Fig. 13F, G). 
Figura 13: Imunolocalização de HEX 70a nos testíolos de zangões adultos faratos (6 dias após a ecdise pupal; estágio do desenvolvimento mostrado na margem esquerda superior). (A, C) Microscopia de luz dos testíolos corados com azul de metileno e fucsina básica. Agrupamento sincicial de espermátides está indicado por setas. (B, D) Imagens de microscopia confocal mostrando a marcação de F-actina com rodamina/faloidina (verde) e a marcação dos núcleos das células com DAPI (azul). A associação da actina com as cabeças de espermátides nos agrupamentos sinciciais está evidente em B (setas) e em uma imagem similar e amplificada em D (setas). (E-G) Microscopia confocal mostrando (E) núcleos marcados com DAPI nos agrupamentos sinciciais de espermátides (asteriscos) e nos núcleos das células somáticas do cisto (pontas de seta); (F) HEX 70a foi localizada com antiHEX 70a/Cy3 (vermelho) na extremidade posterior dos núcleos das espermátides no agrupamento sincicial (mostrado em maior aumento na lateral esquerda superior): setas apontam para os espermatozoides individualizados e a ponta de seta indica um núcleo de célula somática. (G) A sobreposição das imagens $\mathbf{E}-\mathbf{F}$ mostra o aglomerado sincicial de espermátides (inserto), espermatozoides individualizados (setas) e núcleos das células somáticas do cisto (ponta de seta). 


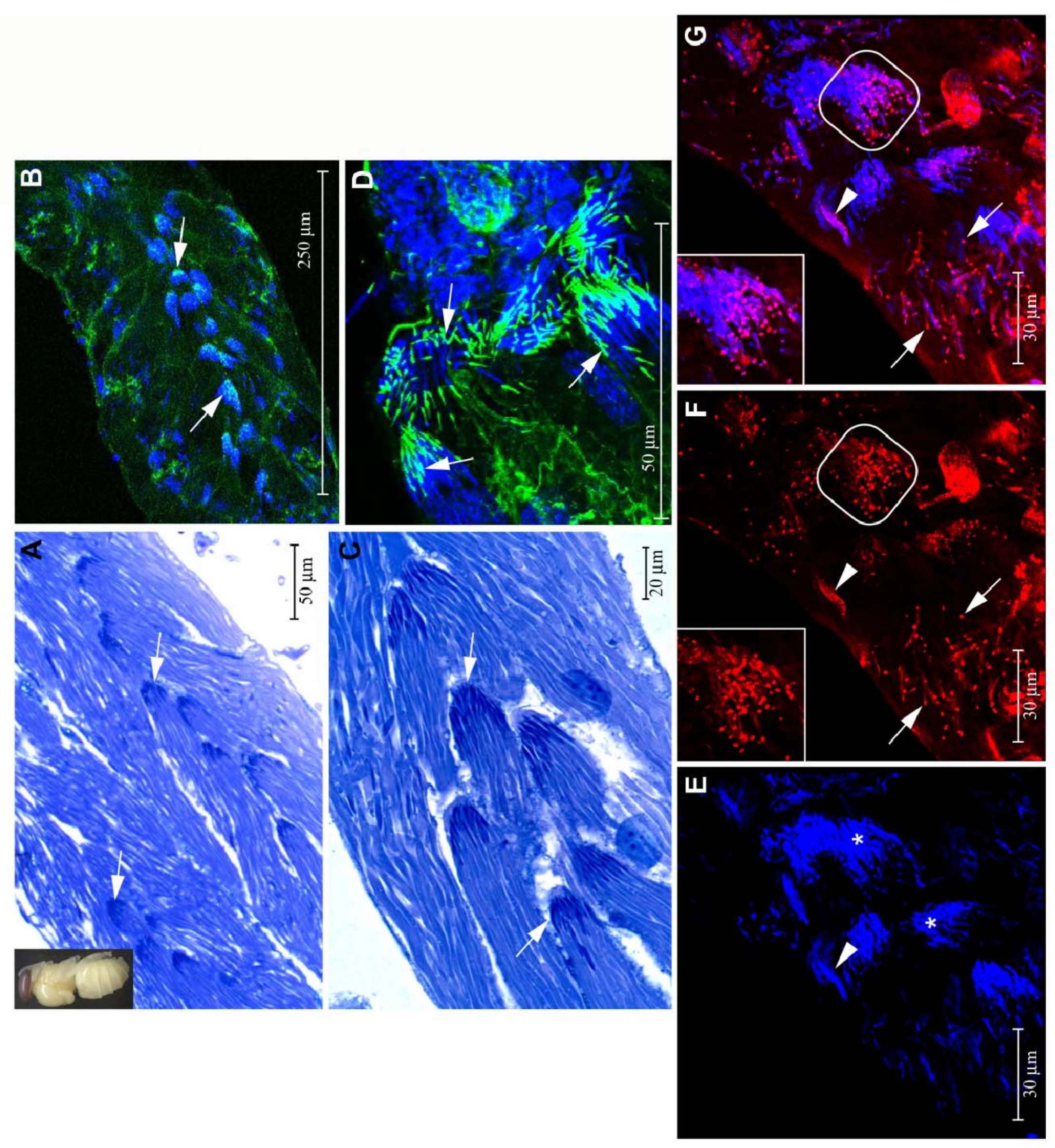




\section{Colocalização de EdU e HEX 70a no núcleo das células ovarianas de operárias adultas} faratas

EdU é um nucleosídeo análogo da timidina que é incorporado ao DNA durante a fase $\mathrm{S}$ do ciclo celular, o que permite a detecção da replicação do DNA e divisão celular quando acoplado a um fluoróforo (Alexa Fluor 594). EdU foi injetado em pupas de operárias (1 dia após a ecdise pupal). Os ovários foram dissecados depois de $24 \mathrm{~h}$, quando as operárias iniciavam o desenvolvimento adulto farato, e preparados para microscopia confocal. As Fig. 14A-D mostram as imagens de um desses ovários. Na Fig. 14A a marcação com DAPI permite a visualização dos núcleos das células na base dos ovários e nos ovaríolos individualizados. Somente a região do germário é mostrada em cada ovaríolo. A Fig. 14B revela a localização intranuclear da HEX 70a por toda a extensão do ovário. Por comparação entre as Fig. 14A e 14B, pode-se identificar regiões nucleares marcadas com DAPI nos ovaríolos (germário), mas não marcadas com HEX 70a/Cy3. Sendo assim, HEX 70a não está presente em todos os núcleos ovarianos. A Fig. 14C mostra a incorporação de EdU em núcleos que estão na fase S. Em análise comparativa, as Fig. 14B, C e as imagens sobrepostas visualizadas na Fig. 14D revelam que os núcleos marcados com EdU/Alexa Fluor também mostram marcação por HEX 70a/Cy3, sugerindo que HEX 70a pode estar de alguma forma envolvida nos eventos da fase S e na proliferação celular dos ovaríolos. Entretanto, HEX 70a também localiza-se nos núcleos de células que não estão em fase S: por exemplo, os núcleos que mostram imunofluorescência da HEX 70a na margem direita do ovário na Fig. 14B não mostram a fluorescência de EdU (Fig. 14C, D). 
Figura 14: Colocalização de anti-HEX 70a/Cy3 e EdU/Alexa Fluor nos ovários de uma operária adulta farata (2 dias após a ecdise pupal: mostrada na região superior esquerda da figura). (A) Núcleo das células ovarianas marcado com DAPI (azul). Para maior clareza, os ovaríolos estão delimitados por linhas tracejadas acima da porção basal dos ovários. Somente a região do germário é apresentada em cada ovaríolo. (B) HEX 70a foi detectada com anti-HEX 70a/Cy3 (vermelho). (C) Localização de EdU/Alexa Fluor no núcleo dos ovários em fase S (amarelo). (D) Sobreposição das imagens B e C. As circunferências em B-D enfatizam os grupos de cistócitos (na região do germário) mostrando dupla marcação (anti-HEX 70a/Cy3 e EdU/Alexa Fluor). O grupo de cistócitos em destaque na posição mais a direita em $\mathbf{D}$ está em maior aumento no inserto. Núcleos das células da margem direita do ovário em B (pontas de seta) mostram marcação de HEX 70a/Cy3 mas não de EdU/Alexa Fluor. 


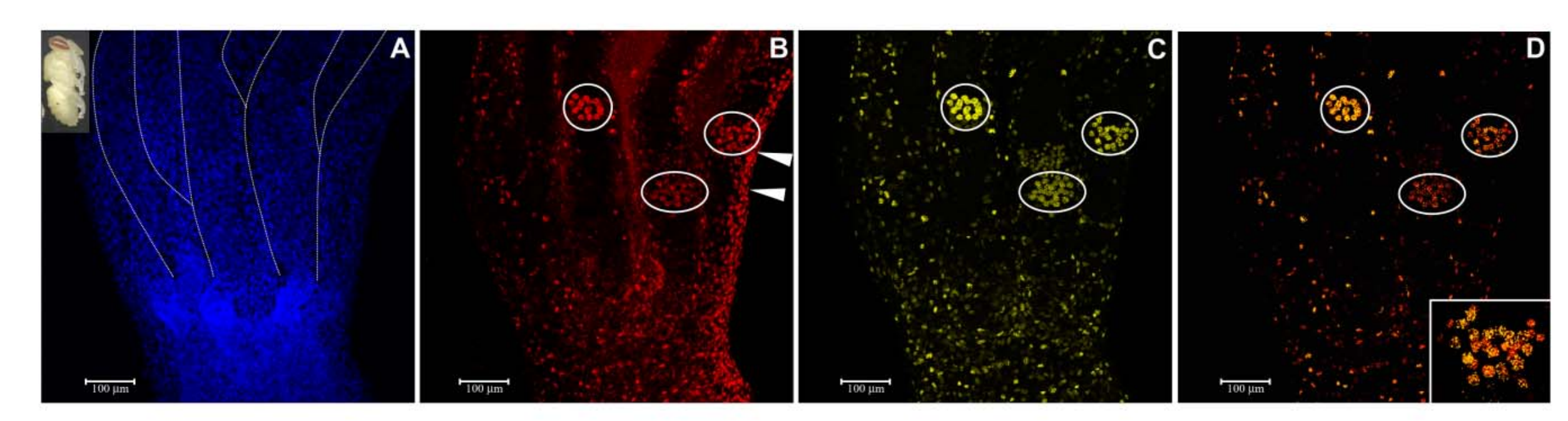




\section{Efeito da injeção do anticorpo anti-HEX 70a na largura dos ovaríolos e esclerotização cuticular}

Para reforçar a hipótese de que a hexamerina HEX 70a está envolvida na proliferação das células dos ovaríolos, nós injetamos anticorpo anti-HEX 70a (diluído em 0,9\% $\mathrm{NaCl}$ ) em pupas de rainha, 24 h após a ecdise pupal, e a largura dos ovaríolos foi determinada logo após a ecdise adulta. A Fig. 15A mostra que a injeção do anticorpo inibiu significantemente o crescimento dos ovaríolos $(\mathrm{p}=0,002)$ em comparação aos ovaríolos das rainhas controles, injetadas somente com $0,9 \% \mathrm{NaCl}$ sugerindo participação da $\mathrm{HEX} 70 \mathrm{a}$ na proliferação das células dos ovaríolos.

Em paralelo, pupas de operárias, 24 h após a ecdise pupal, foram injetadas com antiHEX 70a e o efeito deste anticorpo sobre os níveis de HEX 70a foi examinado. western blots revelaram redução de 54\% (estimada por densitometria das bandas de HEX 70a normalizadas com uma banda de lipoforina de expressão constitutiva) nos níveis de HEX 70a, 4 h após a injeção do anticorpo, seguida de recuperação para níveis normais após 72 h (Fig. 15B).

Visto que a HEX 70a é uma arilforina (ver item III 1 - Resultados), e como tal pode representar uma fonte de aminoácidos aromáticos necessários para a formação da cutícula, também checamos o progresso da pigmentação e esclerotização cuticular das operárias injetadas com anti-HEX 70a, comparadas aos dois grupos controle, injetados com IgG de camundongo ou somente com o diluente de anti-HEX e IgG. A injeção de anti-HEX 70a causou um efeito drástico na formação da cutícula. Este efeito foi mais evidente na cutícula das pernas traseiras das operárias que mostraram-se incompletamente pigmentadas e esclerotizadas. Nas abelhas tratadas com anti-HEX 70a, a cutícula das pernas traseiras revelou-se mais clara e mais flexível que as dos grupos controles (Fig. 15C). 
B
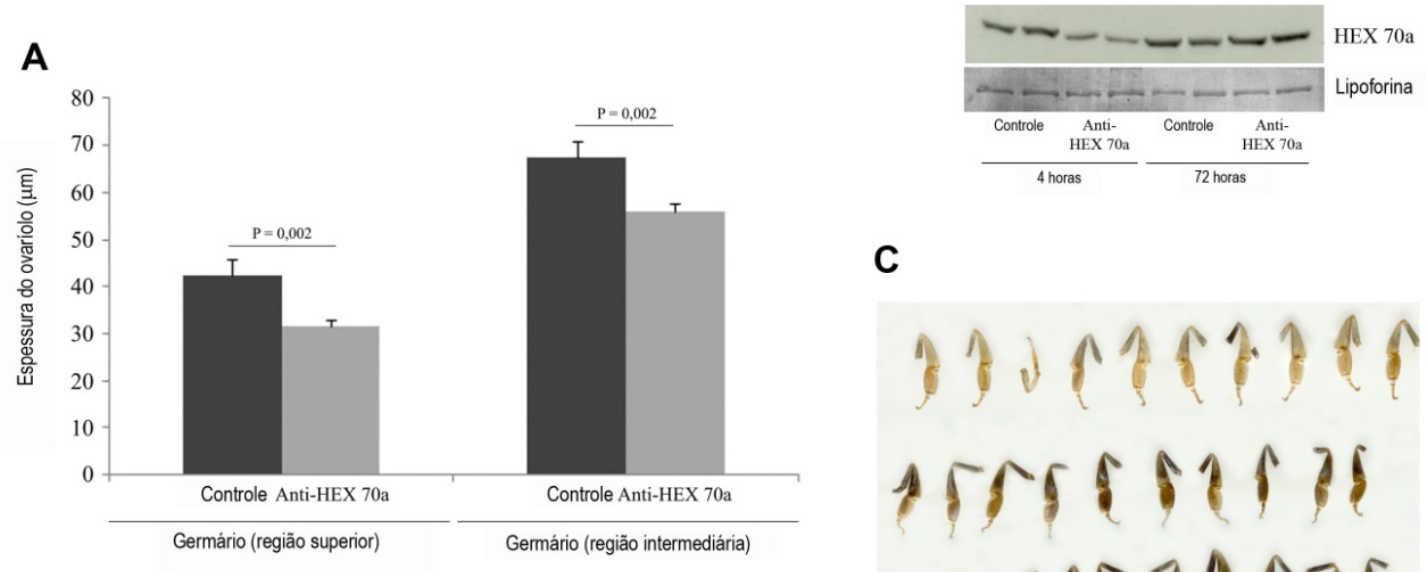

C

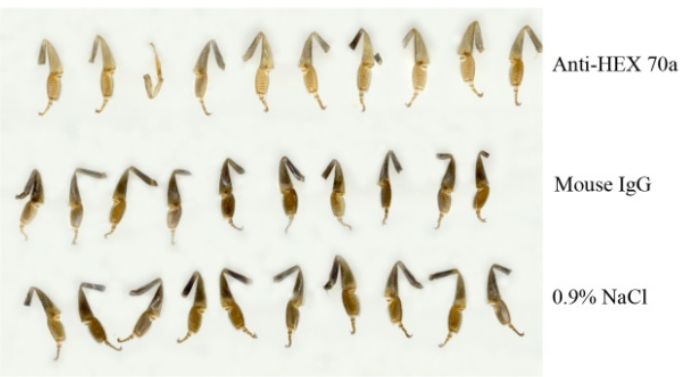

Figura 15: Efeito de anti-HEX 70a nos ovários de rainhas e na diferenciação da cutícula de operárias. (A) Espessura dos ovaríolos de rainhas injetadas com anti-HEX 70a (diluído em $0,9 \% \mathrm{NaCl}$ ) e respectivos controles injetados somente com $0,9 \% \mathrm{NaCl}$. As medidas foram feitas em duas regiões do germário de 120 ovaríolos, 60 deles foram dissecados de 3 rainhas injetadas com anti-HEX 70a (20 ovaríolos por rainha), e os outros 60 foram dissecados das 3 rainhas do grupo controle. As medidas obtidas das abelhas injetadas com anticorpo, ou somente com o diluente do anticorpo, foram comparados usando teste $\mathrm{T}$ (Jandel SigmaStat 3.1 software, Jandel Corporation, San Rafael, CA, USA). (B) Western blot dos níveis de HEX 70a nas amostras de hemolinfa de operárias, 4 e 72 h após a injeção com anti-HEX 70a ou NaCl 0,9\% (controle). Os níveis de lipoforina, proteína da hemolinfa de expressão constitutiva, serviram como normalizador. (C) Pernas traseiras de operárias injetadas com anti-HEX 70a diluído em $0,9 \% \mathrm{NaCl}$, em comparação às operárias injetadas com $\mathrm{IgG}$ de camundongo em $0,9 \% \mathrm{NaCl}$, ou injetadas somente com $0,9 \% \mathrm{NaCl}$.

Análises por microscopia eletrônica de transmissão (Fig. 16) das tíbias do $3^{\circ}$ par de pernas das operárias tratadas com $0,9 \% \mathrm{NaCl}$ (controles) (Fig. 16A e B) ou com anti-HEX 70a diluído em $\mathrm{NaCl}$ 0,9\% (Fig. 16C e D) mostraram significativa alteração na espessura da cutícula (setas). A camada cuticular é mais espessa nas operárias controles. Nas operárias que tiveram os níveis de HEX 70a diminuídos, a cutícula estava mais fina, o que reforça a hipótese de que esta hexamerina seja uma importante fonte de aminoácidos para a deposição cuticular. 

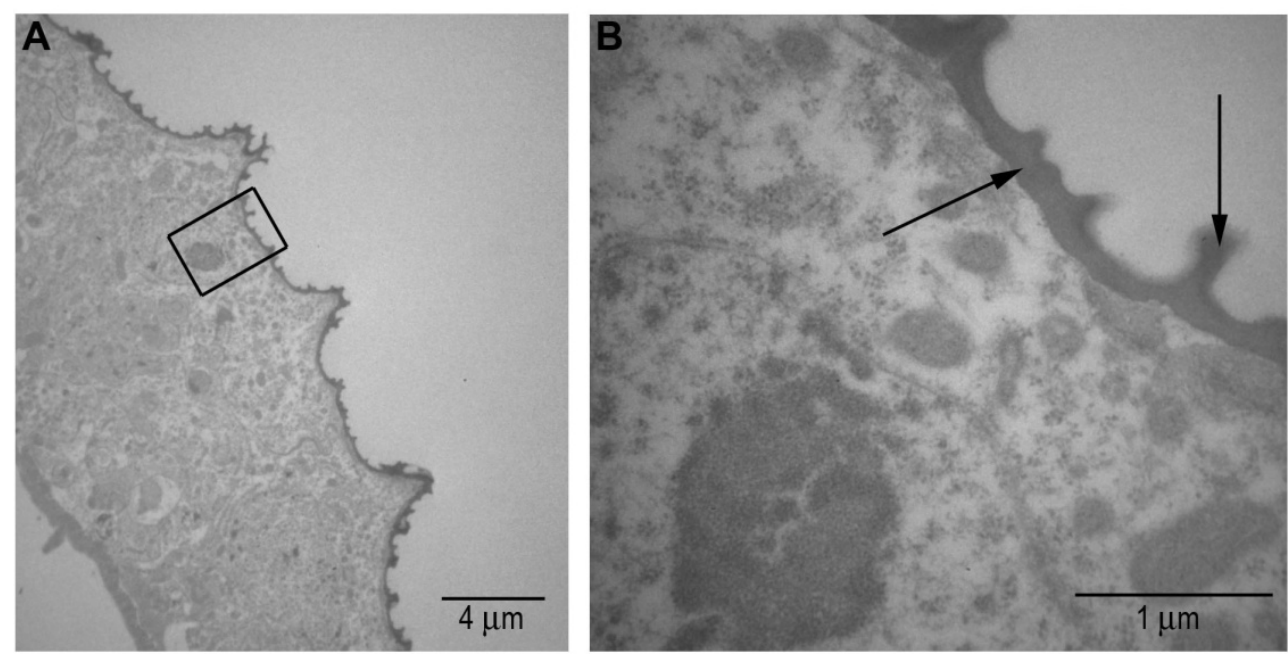

$0,9 \% \mathrm{NaCl}$
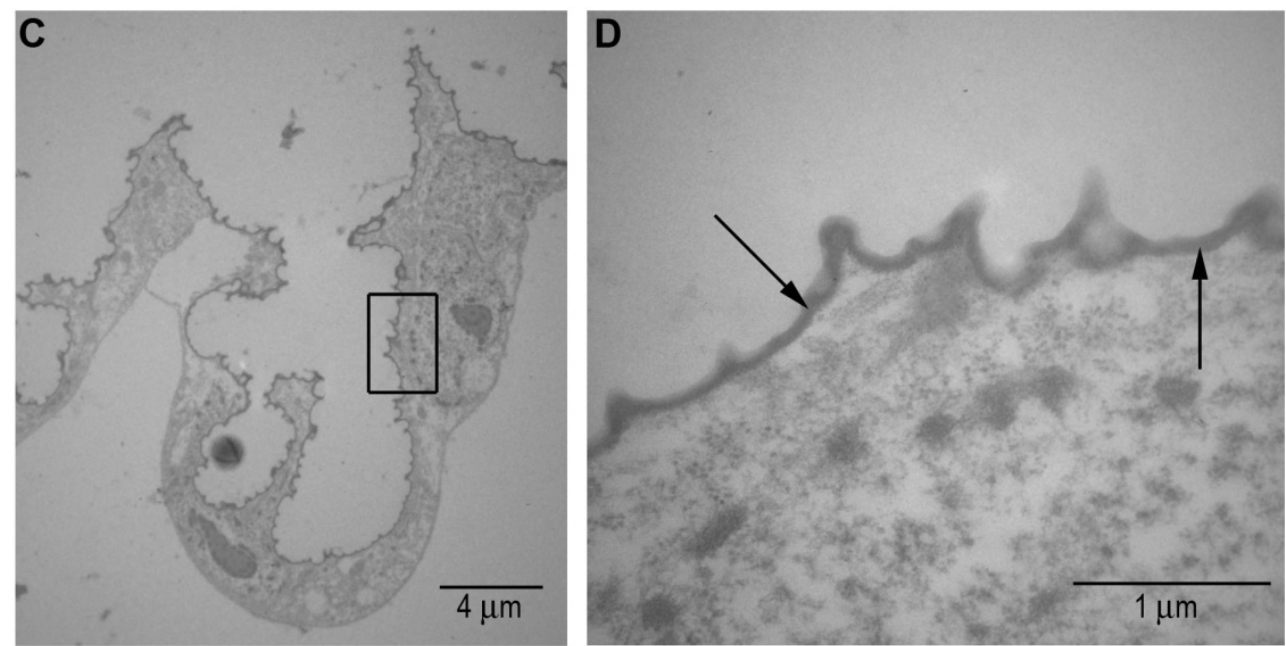

anti-HEX 70a

Figura 16: Microscopia eletrônia de transmissão das tíbias do $3^{\circ}$ par de pernas de operárias injetadas com $(\mathbf{A}, \mathbf{B})$ $\mathrm{NaCl}$ 0,9\% (controle) ou com (C, D) anti-HEX 70a. As regiões delimitadas em $\mathbf{A}$ e $\mathbf{C}$ estão representadas em $\mathbf{B}$ e D..

\section{Injeção de anticorpos anti-hexamerinas em operárias adultas faratas: efeito sobre a sobrevivência e duração do período adulto farato}

A injeção de cada anticorpo contra as hexamerinas em operárias em início do período adulto farato (fase $\mathrm{Pp}$ ) resultou em uma diminuição dos níveis destas proteínas na hemolinfa e no corpo gorduroso $4 \mathrm{~h}$ e/ou $24 \mathrm{~h}$ após a injeção (Fig. 17A). No período do experimento, a abundância de HEX 110 está diminuindo na hemolinfa; os níveis de HEX 70c devem cair um pouco mais tarde (antes da fase Pbm), e os de HEX 70a permanecem altos (ver Fig. 4). De fato, 4h após a injeção de anti-HEX 110 ou anti-HEX 70a, os níveis das respectivas proteínas diminuiram na hemolinfa. Entretanto, níveis normais de HEX 70a foram recuperados 24h após a injeção. A diminuição dos níveis de HEX 70c foi constatada 24h após a injeção (Fig. 17A). Como os níveis de HEX $70 \mathrm{~b}$ diminuem na hemolinfa durante a fase de desenvolvimento correspondente a 24 h após a injeção (fase Pb) (ver Fig. 4), as análises do 
efeito do anticorpo anti-HEX $70 \mathrm{~b}$ foram realizadas com o corpo gorduroso, onde os níveis desta hexamerina permanecem altos (Fig. 4). A Fig. 17A mostra diminuição dos níveis de HEX 70b em consequência da injeção do anticorpo.

As injeções não afetaram significantemente $(p=0,524)$ a sobrevivência até a ecdise adulta (Fig. 17B). No entanto, as abelhas injetadas com os anticorpos contra as hexamerinas mostraram aceleração do desenvolvimento e passaram pela ecdise adulta significantemente mais cedo que os controles injetados com $0,9 \% \mathrm{NaCl}$ ou $\mathrm{IgG}$ de camundongo $(\mathrm{p}=0,019)$ (Fig. 17C).

A

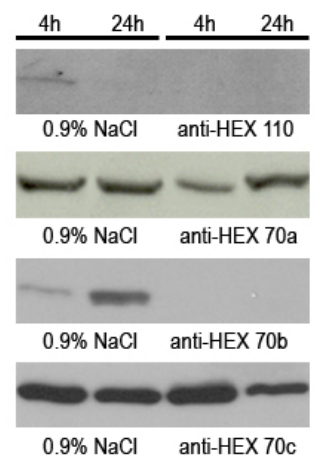

B

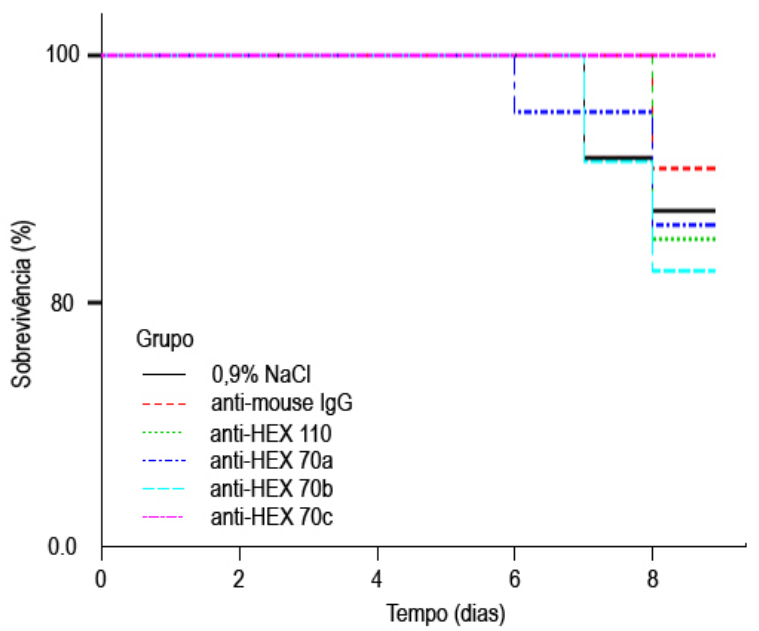

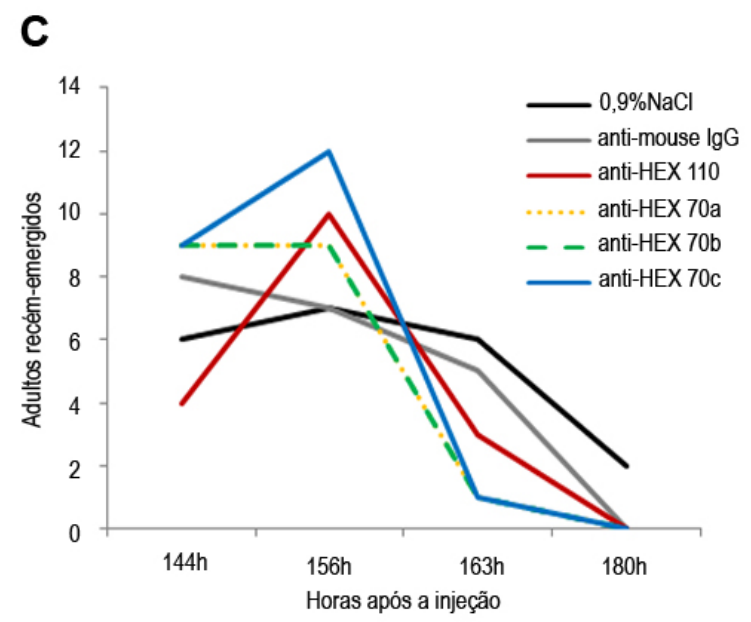

Figura 17: Efeito da injeção de anti-hexamerinas em operárias adultas faratas (fase Pp). (A) Western blots mostram a diminuição de HEX 110, HEX 70a e HEX 70c na hemolinfa, e a diminuição de HEX 70b no corpo gorduroso de adultas faratas $(\mathrm{Pb}) 4$ e/ou $24 \mathrm{~h}$ após a injeção de $1 \mu \mathrm{g}$ dos respectivos anticorpos diluídos em $0,9 \%$ $\mathrm{NaCl}$. Grupos controles foram injetados com $0,9 \% \mathrm{NaCl}$ ou com $1 \mu \mathrm{g}$ de $\mathrm{IgG}$ de camundongo em $0,9 \% \mathrm{NaCl}$. (B) Todos os grupos de abelhas (cada um contendo 22 abelhas) mostraram taxas de sobrevivência similares, independente da injeção de anti-hexamerinas $(p=0,524)$. (C) Os grupos injetados e controles diferiram significantemente no tempo de desenvolvimento até atingir a ecdise adulta $(p=0,019)$. Os dados foram 
analizados usando Kaplan-Meier: Log-Rank seguido por teste de múltiplas comparações ( $\chi^{2}$ teste) (software de estatística R, versão 2.15.0).

\section{Regulação da expressão dos genes de hexamerinas}

\section{Efeito do HJ sobre a expressão dos genes de hexamerinas em larvas de $5^{\circ}$ instar}

$\mathrm{O}$ tratamento com $\mathrm{HJ}$ foi realizado em larvas de $5^{\circ}$ instar (L5F) com o objetivo de manter os títulos deste hormônio em altos níveis por um prolongado período de tempo, contornando a diminuição natural que normalmente ocorre na transição das fases de alimentação (L5F) para a de construção do casulo (L5S) (Rachinsky et al. 1990).

A Fig. 18 mostra que a expressão dos genes hex $70 b$ e hex 70c é nitidamente maior nas larvas tratadas com HJ com relação aos controles, embora o efeito do HJ sobre a expressão dos genes hex 70a e hex 110 seja mais discreto. Juntos, estes resultados suportam uma função do HJ na indução da expressão dos genes de hexamerinas.

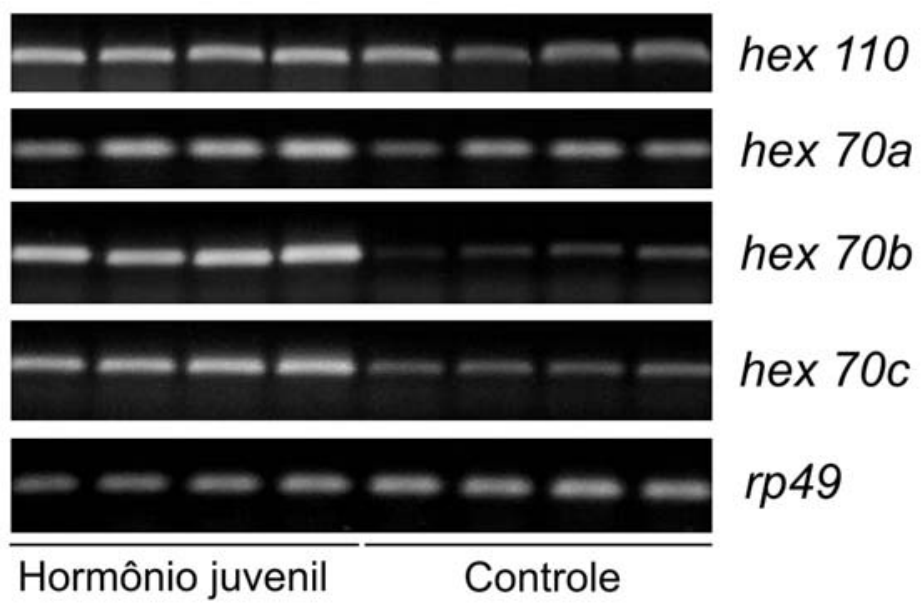

Figura 18: Efeito do hormônio juvenil sobre a expressão dos 4 genes de hexamerinas. O hormônio (diluído em acetona) foi topicamente aplicado sobre o dorso de larvas do $5^{\circ}$ instar (fase de alimentação, L5F). Controles foram tratados somente com a acetona. A expressão do gene foi analisada 24 h após o tratamento. A abundância dos transcritos de hexamerinas foi analisada por RT-PCR seguida por eletroforese do cDNA amplificado em géis de agarose corados com brometo de etídeo. O gene rp49 de A. mellifera foi utilizado como normalizador. 


\section{Regulação da expressão dos genes de hexamerina pela dieta alimentar}

\subsection{Efeito da dieta oferecida à colmeia sobre o desenvolvimento larval e expressão dos genes de hexamerinas}

Por meio da manipulação da quantidade de pólen disponibilizado para a colmeia foi possível, indiretamente, influenciar o status nutricional das larvas e verificar se os níveis de transcritos dos gene hex 70c e dos outros três genes de hexamerinas, são nutricionalmente regulados nas larvas.

Duas colmeias foram confinadas em gaiolas revestidas por uma tela que impede o acesso das abelhas forrageiras a qualquer fonte de alimento externo. Dois tipos de dietas contendo 5 ou $20 \%$ de pólen foram oferecidas, separadamente, a duas colmeias, cada uma abrigada em uma gaiola. Larvas originárias da colmeia que recebeu a dieta com 5\% de pólen apresentaram peso 4 vezes menor que larvas da colmeia alimentada com a dieta contendo 20\% de pólen ( $\mathrm{p}=0,009)$ (Fig. 19A). Quantificação das proteínas da hemolinfa (Fig. 19B) e do corpo gorduroso (Fig. 19C) destas larvas, assim como do RNA total extraído do corpo gorduroso (Fig. 19D) mostrou níveis significativamente mais baixos $(p=0,001 ; p=0,005 ; p$ $=0,004$, respectivamente) nas larvas que se desenvolveram na colmeia alimentada com $5 \%$ de pólen.

A

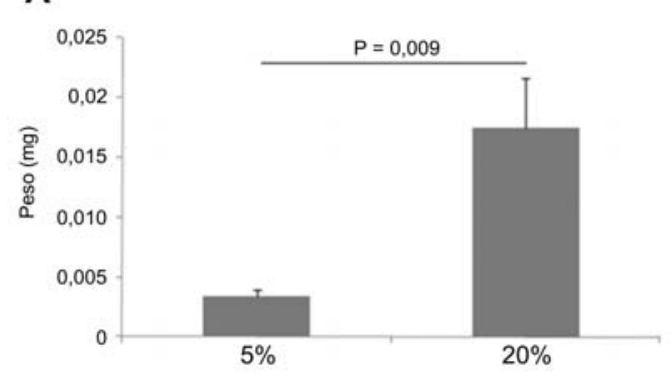

C

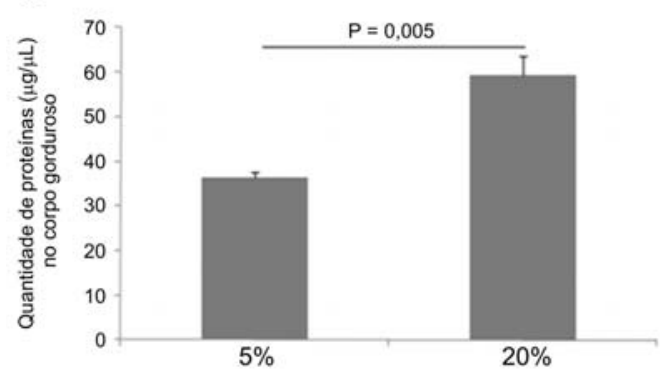

B

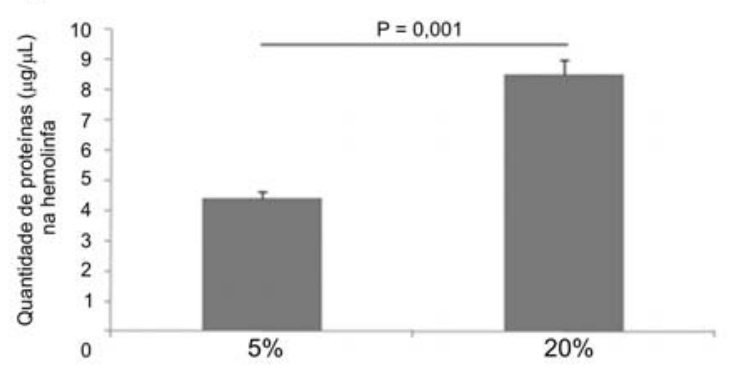

D

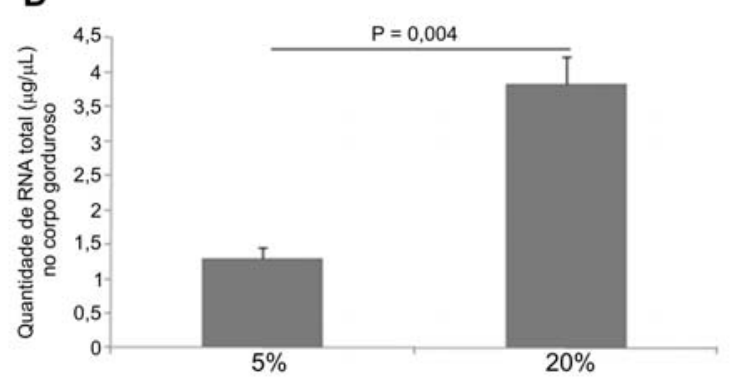

Figura 19: Efeito da concentração de pólen na dieta oferecida à colmeia sobre o desenvolvimento larval. (A) Peso das larvas (mg). (B) Quantidade de proteínas na hemolinfa $(\mu \mathrm{g} / \mu \mathrm{L})$. (C) Quantidade de proteínas no corpo gorduroso $(\mu \mathrm{g} / \mu \mathrm{L})$. (D) Quantidade de RNA total no corpo gorduroso $(\mu \mathrm{g} / \mu \mathrm{L})$. 
A concentração de pólen na dieta de uma colmeia foi capaz de inibir ou estimular a produção de transcritos de hexamerinas (Fig. 20A). As larvas coletadas da colmeia alimentada com dieta contendo $5 \%$ de pólen mostraram níveis menores de transcritos de hexamerinas. Este efeito foi mais evidente para os genes hex110, hex $70 a$ e hex $70 b$. Um efeito mais discreto foi observado para o gene hex 70c. A expressão do gene que codifica a lipoforina I/II, proteína de estocagem de alta massa molecular, também foi prejudicada em consequência da alimentação pobre em pólen (Fig. 20B).

Análise da expressão de um gene da via da insulina, ILP2 (Insulin-like peptide 2), mostrou que também é reprimido pela baixa quantidade de pólen no alimento (Fig. 20C). No entanto, a expressão de outros genes como chico (Fig. 20D) e TOR (target-of-rapamycin) (Fig. 20E) não foi significantemente modificada.

O gene codificador de uma isoforma do receptor de ecdisona, EcRa (Fig. 20F), também mostrou menor expressão em consequência da baixa quantidade de pólen na dieta. No entanto, o gene que codifica a outra isoforma do receptor de ecdisona, EcRb (Fig. 20G), assim como ultraspiracle, que codifica a proteína Usp que junto com EcR forma o complexo heterodimérico de ligação a ecdisona, não mostraram alteração significante de expressão (Fig. 20H). O gene mfe2 (metil farnesoato epoxidase 2) (Fig. 20I), da via de síntese do HJ, assim como os genes codificadores de enzimas que degradam este hormônio, jhe (esterase) (Fig. 20J) e jheh (epóxido hidrolase do HJ) (Fig. 20K) também mostraram baixa expressão em larvas criadas em colmeias que receberam pouca quantidade de pólen. 
Figura 20: Efeito da concentração de pólen na dieta oferecida à colméia sobre a expressão dos (A) genes de hexamerinas e de outros genes: (C-E) com função na via de insulina, (F-G) genes receptores de ecdisona, (I) genes da via de síntese e (J-K) de degradação do HJ. (A) Produto de RT-PCR semi-quantitativa analisado em gel de agarose 1\%, corado com brometo de etídio. (B-K) Quantificação de transcritos por qRT-PCR. Os níveis de mRNA foram comparados utilizando-se o teste T (Jandel SigmaStat 3.1 software, Jandel Corporation, San Rafael, CA, USA). O gene rp49 foi utilizado como normalizador na amplificação por PCR. 

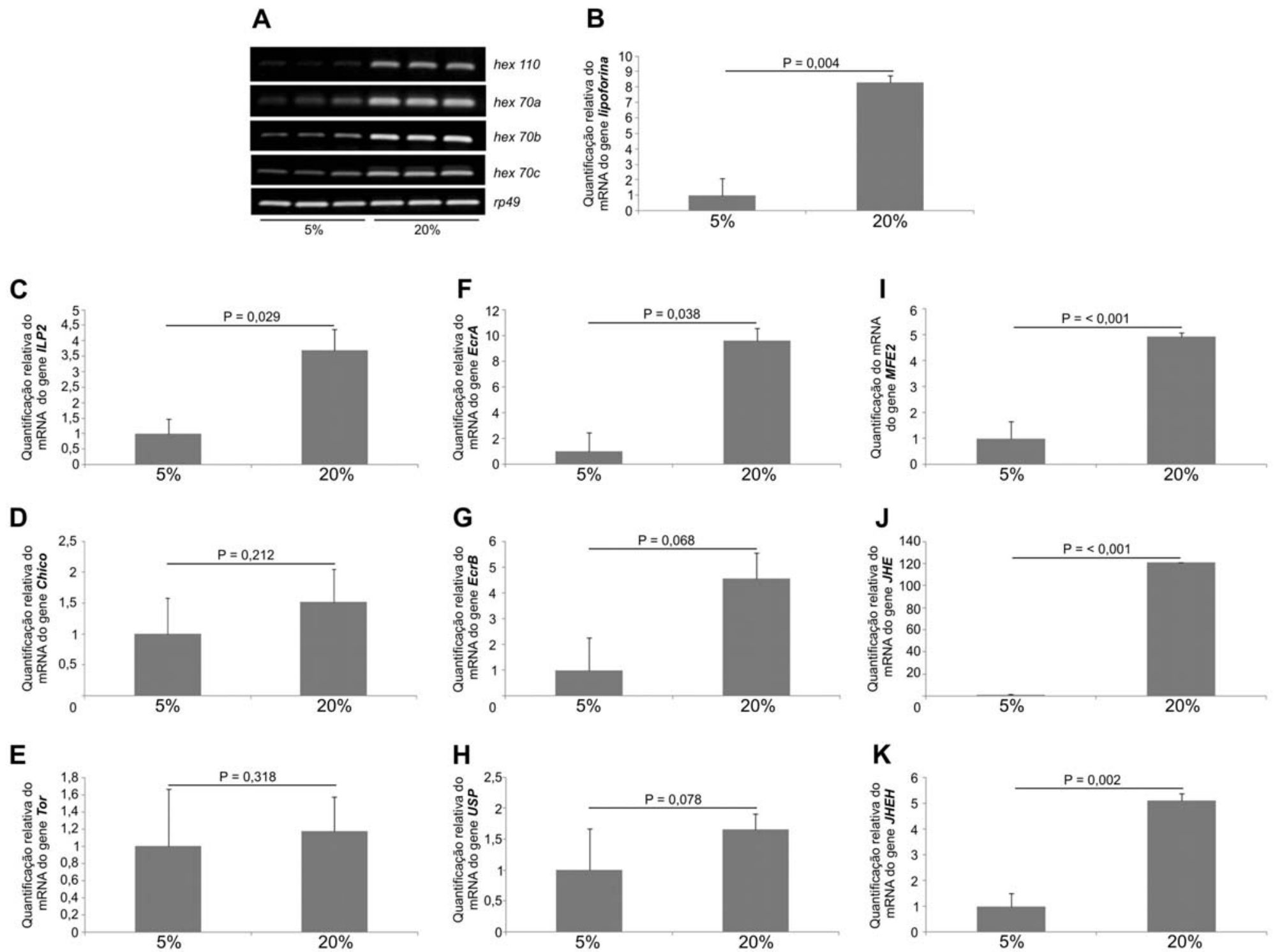


\subsection{Alternância da dieta de larvas de operárias e rainhas e efeitos sobre a expressão dos genes de hexamerinas}

A transferência de larvas L1 dos alvéolos de operárias, onde permaneceram por 2 dias, para cúpulas de rainhas para permanência por mais 2 dias (grupo 2Op2Ra), provocou alteração da dieta nutricional e as larvas antes destinadas a se tornarem operárias alcançaram tamanho corporal semelhante às larvas mantidas por 4 dias nas cúpulas de rainhas, as quais receberam, exclusivamente, alimento de rainha (grupo 4Ra) (Fig. 21A). As larvas mantidas por 2 dias em cúpulas de rainha e, subsequentemente, transferidas para os alvéolos de operárias, onde permaneceram por mais 2 dias (grupo 2Ra2Op), mostraram tamanho semelhante àquelas que passaram os 4 dias nos alvéolos de operárias, consumindo exclusivamente alimento de operária (grupo 4Op) (Fig. 21A). Este resultado foi confirmado pela pesagem das larvas. As larvas do grupo 2Op2Ra apresentaram um aumento significativo do peso corporal ( $\mathrm{p} \leq 0,001$ ), equivalente ao observado em larvas do grupo 4Ra. As larvas 2Ra2Op mostraram um valor de massa corpórea similar às larvas do grupo 4Op. Os grupos 2Ra2Op e 2Op2Ra não diferiram significativamente quanto ao peso corporal (Fig. 21B). Análises da expressão dos genes de hexamerinas em todos os grupos mostraram alteração na densidade de transcritos de apenas um deles, hex 70a (Fig. 21D). Larvas do grupo 4Op apresentaram cerca de 25 vezes mais transcritos deste gene em relação às larvas do grupo 4Ra. Larvas 2Op2Ra mostraram níveis significativamente mais baixos de transcritos de hex $70 a(\mathrm{p}=0,001$; One-way ANOVA - Holm Sidak) quando comparados aos níveis de transcritos de larvas do grupo 4Op. As larvas do grupo 2Ra2Op não diferiram significativamente quanto aos níveis de transcritos em relação às dos grupos 4Ra e 4Op. Perfil de expressão similar foi observado para a proteína HEX 70a da hemolinfa destas larvas (Fig. 21G). Os outros genes de hexamerinas, hex 110 (Fig. 21C), hex $70 b$ (Fig. 21E) e hex 70c (Fig. 21F), não apresentaram modificação significativa na densidade de transcritos e da proteína em consequência da variação da dieta, no período de tempo de duração do experimento. 

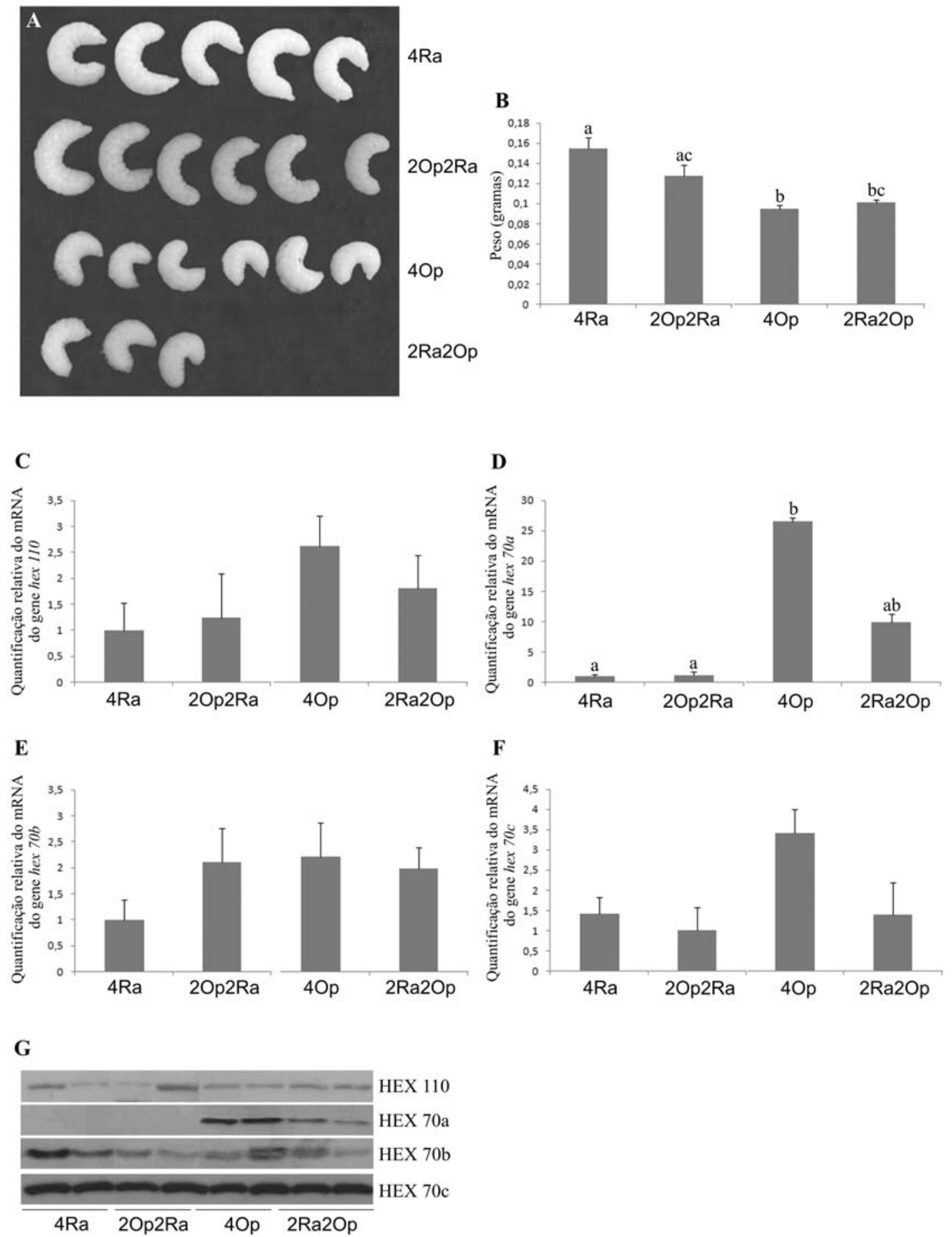

Figura 21: Manipulação experimental da dieta larval. (A) Larvas L1 alimentadas exclusivamente, durante 4 dias, com alimento de rainhas (grupo 4Ra) ou com alimento de operárias (grupo 4Op). Larvas L1 alimentadas durante 2 dias com alimento de operárias e em seguida por mais 2 dias com alimento de rainhas (grupo 2Op2Ra). Larvas L1 alimentadas durante 2 dias com alimento de rainhas e em seguida por mais 2 dias com alimento de operárias (grupo 2Ra2Op). (B) Peso em gramas. Letras diferentes indicam diferenças estatisticamente significantes (Oneway ANOVA; Holm Sydak; SigmaStat 3.5 software, Jandel Corporation, USA). (C-F) qRT-PCR para quantificação de transcritos dos genes de hexamerinas (hex 110, hex 70a, hex 70b e hex 70c). O gene rp49 foi utilizado como normalizador. Letras diferentes indicam diferenças estatisticamente significantes $(p<0,001$ Oneway ANOVA; $\mathrm{p} \leq$ 0,05 Holm Sidak; SigmaStat 3.5 software, Jandel Corporation, USA). (G) Western blot de amostras de hemolinfa utilizando-se anticorpos contra cada subunidade de hexamerina. 


\section{Características das subunidades HEX 70a, HEX 70b, HEX 70c e HEX 110}

\section{Estudo da estrutura das subunidades de hexamerinas}

A sequência N-terminal de cada subunidade de hexamerinas (HEX 70a, HEX 70b, HEX 70c e HEX 110) foi determinada por Danty et al. (1998). Todas elas contém os domínios de hemocianina conservados N, M e C (N: PF03722.5, M: PF00372.10 e C: PF03723.5 - base de dados Pfam, Bateman et al., 2004) (Fig. 22A). Também foi previamente demonstrado (Bitondi et al., 2006) que o domínio de hemocianina C da HEX 110 é interrompido por uma inserção de 291 aminoácidos. Esta inserção é muito rica em glutamina e ácido glutâmico (Glx) e contribui significativamente para o total de Glx (20,9\%) da HEX 110.

O sequenciamento completo dos 4 genes de hexamerinas [Cunha et al., 2005 (hex 70b); Martins, 2008; Martins et al., 2008; Martins et al., 2010 (hex 70a, hex 70c e hex 110)] seguido da análise das sequências de aminoácidos preditas possibilitou identificar a presença de sítios de glicosilação, uma histidina conservada e motivos tipicamente encontrados em outras hexamerinas de insetos (Fig. 22B). O software http://phobius.sbc.su.se foi utilizado para a predição de peptídeos sinal e topologia transmembrana das sequências de aminoácidos de cada subunidade de hexamerina. As quatro subunidades contêm peptídeo sinal que dirige o transporte das proteínas. Como esperado, nenhuma das subunidades contém domínio transmembrana. Com respeito à composição de aminoácidos, HEX 70a e HEX 70c contêm uma quantidade relativamente elevada de fenilalanina, triptofano e tirosina (18,2\% e 16,9\%, respectivamente), e pertencem à classe das hexamerinas ricas em aminoácidos aromáticos (ou arilforinas). Com seu conteúdo relativamente alto de metionina, HEX 70b (4,4\%) e HEX 70c $(6,4 \%)$ puderam ser incluídas na classe das hexamerinas ricas em metionina.

A identidade de aminoácidos entre as hexamerinas de A. mellifera varia de $30 \%$ a 42\%. Múltiplos alinhamentos utilizando ClustalW 1.83 revelaram que HEX 70a, HEX 70b e HEX 70c são mais similares entre si (39 a 42\%) do que com a HEX 110 (30 a 32\% identidade) (Apêndice 4 - Fig. 32). 
Figura 22: (A) Diagramas das sequências de hexamerinas mostrando os domínios de hemocianina conservados N, M e C. O domínio C está interrompido na sequência de HEX 110. (B) Sequências de aminoácidos deduzidas do sequenciamento completo dos genes das hexamerinas. O peptídeo sinal está indicado por linhas pontilhadas e as linhas tracejadas mostram os motivos identificados por Danty et al. (1998). Asteriscos indicam os sítios de glicosilação. A histidina conservada está duplamente sublinhada. O motivo LSP signature-1 está indicado (+++). O motivo LSP signature 2 está em negrito. O sítio de clivagem por protease está sublinhado. A glicina 14 conservada em exopterigotos e endopterigotos está indicada (\#). 


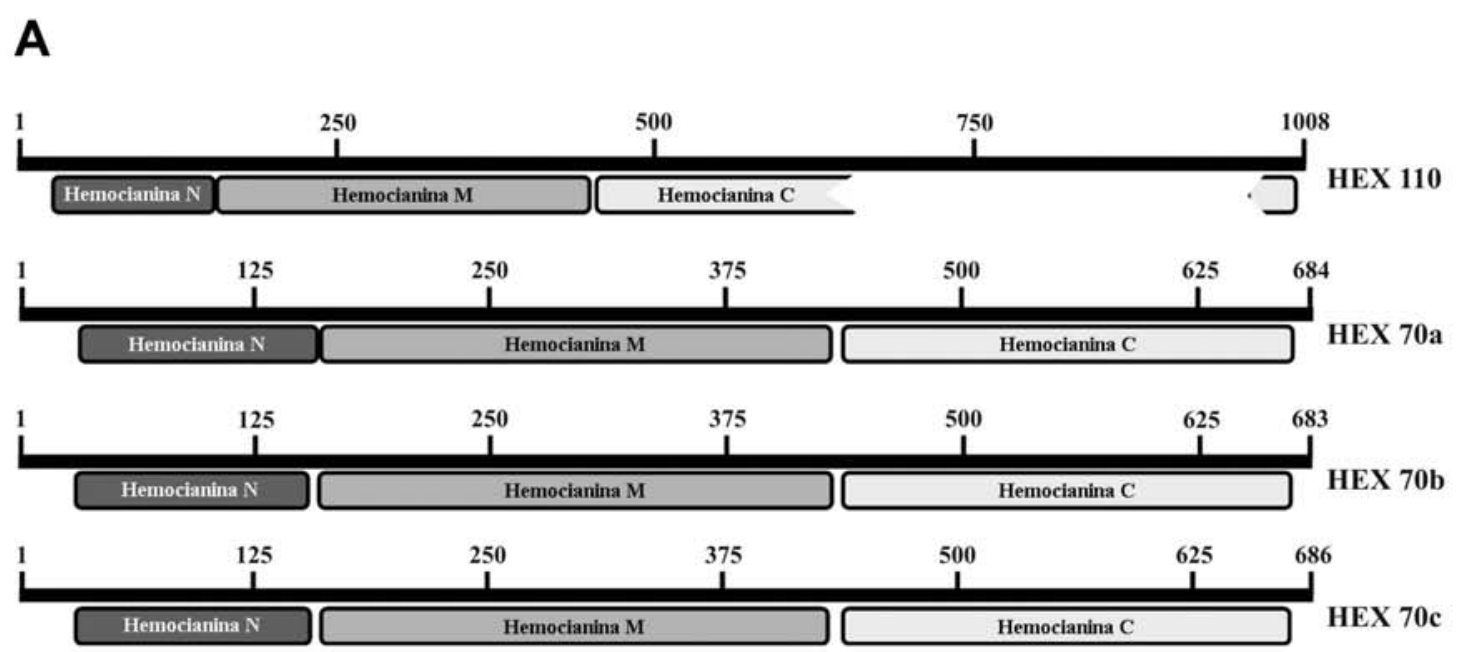

\section{B}

>Hexamerina110 (HEX 110)

MRYEIILIALYALGVCAPNVKORAADQDLLNKOQDVIQLLEKISQPI PNQELQNLGASYDIESNSHQYKN PIIVMYYAGAVKAGLVQPQGTTFSNS ISQLRKEVSLLYRILLGAKDYQTFLKTAAWARVHVNEGQFLKA VAAVLTRQDTQGVIFPPVYEILPQHHLDSRVIQEAQN IAIQNTQGKNNQQNILIPVNYSALLSHDEQQLS YFTQDIGLAAYYQVNLAGYIQEQNQQQQQ QQPLTQQQYQQQIVGKYLQQQAGQQDQQANIGRGAQYLY HQQLLARYELNRLSNGLGPIKDIDYENVQSLYQPHLRGLNGLEFAGRPQNLQLQSQRNQLIQYVATLEKR LRDAIDSGNVITPQGVFLSLYQPQGMNILGDLIEGTGRSVNPRYYGSLQAAARKLLGNAPEVENIWDYT SSLELGEVAVHDPVFYLIKKVMNLY QQYQQSLPVYQYNDLILPGVTIQNVDVSQLVTLFTDFYVDLDA TGHQSQQCQEEQTQSRVRAHLKRLDHQPYQYKIAVHSEQNVPGAVVRVFLGPKHDHQGRPISISKNQHL

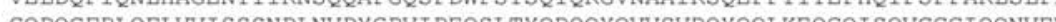
LPENLVNAQQOVQAVRNYYANLYTKYHGQYPNTOI QNPVGQGQDMTY YVQGVGVVNAGGWLGQGNSWS

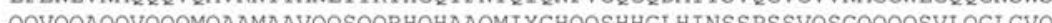
VQR VQGVAVRGGTVASGQQHAGCWQSTYAOPQTVQDQIVSEYYONKPTSEVIGGATSLDGKPLGEPLDRTS LGALSVPNIFVKDVLVFHOGQPTNDITQ

\section{$>$ Hexamerina 70b (HEX 70b)}

\section{$>$ Hexamerina70c (HEX 70c)}

MIVIMKAGFLFLASLCLLV OAVNKVADKTYVTROKNIYELFWHVDOPTVYHPELYOKARTFNLVENLDM YNDKEAVNEFMQLLKHGMLPRGQVETMMNKEMRHQAVVLFRLLYSAKTFDVFYNTAVWARENVNEQMYLY ALSVAVIHRPDTKLMKLPPMYEVMPHLYFNDEVMQKAYNIAMGDTADMKKTYNNIDYYLLAANYTGYI

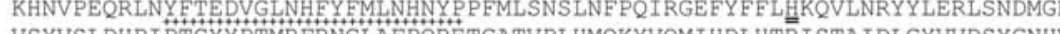

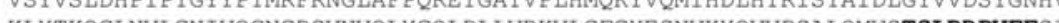

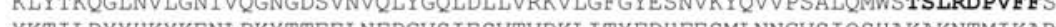
TKTHDYFN

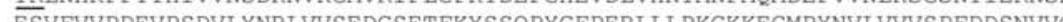
IDSPVWTRHTYDGRAMGEPLDKPVDPLULVLSNIHUK"

MLSKVVLLVALAAICGAO GASYAGRHTADMDELHKOKKIFDLLLYVRQADLSDAEWYDVGRNYDMESNM MYKDKNVVQKFLWWYKQGMFLSRNAIFTPLNSEQKYEVRMLFELIYNAKDFQTFYKTAAWARLRMNSGM TTAFSIAVLYRPDTKMMKFPATYIYNNFFDSSVIEEACNLKMSRGSSVVTGMNNIETYIVNTNYSSKN

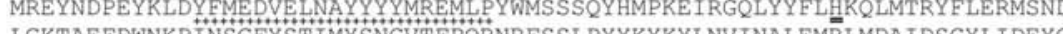
LGKAER DWNKP NSGTSTHMNG KRIDITTEGLNMGN ARRACMNYERFTYKTNTMSDKETKGMORTFIGPAFDETKHDMVYLOKYFYLFMEMDRFAVTIRPGSNST RQSSESPFTTSTIMPSDIFYDKLNKATOSEPFTYSERMLOFPERLILPRGKPEGMRYKMEEFLSSMDES NTKSYEIPLYGKMTLDDKVFGFPLDRPMWAWNETI PNMYEKDVEIYNRPNEESMNY 


\section{Cromatografia para separação das hexamerinas}

A cromatografia por filtração em gel de amostras de hemolinfa de larvas de operárias L5S gerou 10 picos (Fig. 23A). As frações correspondentes foram coletadas e analisadas por SDS-PAGE (Fig. 23B), PAGE não desnaturante (Fig. 23C) e espectrometria de massa. Hexamerinas foram localizadas nas frações 2 e 3, e em gel nativo de poliacrilamida apresentaram massa molecular de aproximadamente $660 \mathrm{kDa}$. Análises por western blot (Fig. 23D) confirmaram a presença das hexamerinas nestes picos. Optou-se pela utilização dos anticorpos em western blots para identificação das hexamerinas nas frações, uma vez que por espectrometria de massa, apenas a HEX 70b foi identificada. A hexamerina HEX 110 não foi detectada nas frações. 
A

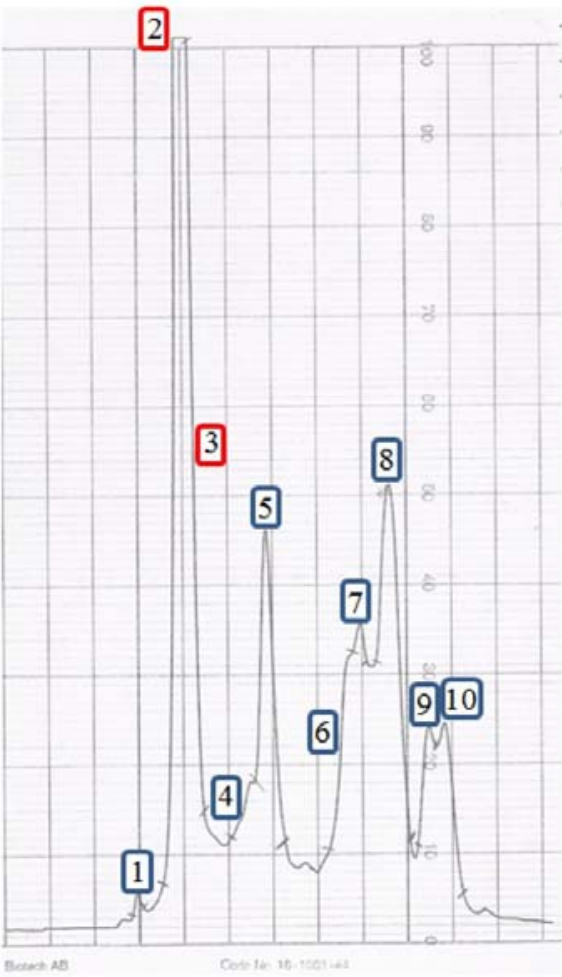

\section{$\mathrm{B}$}

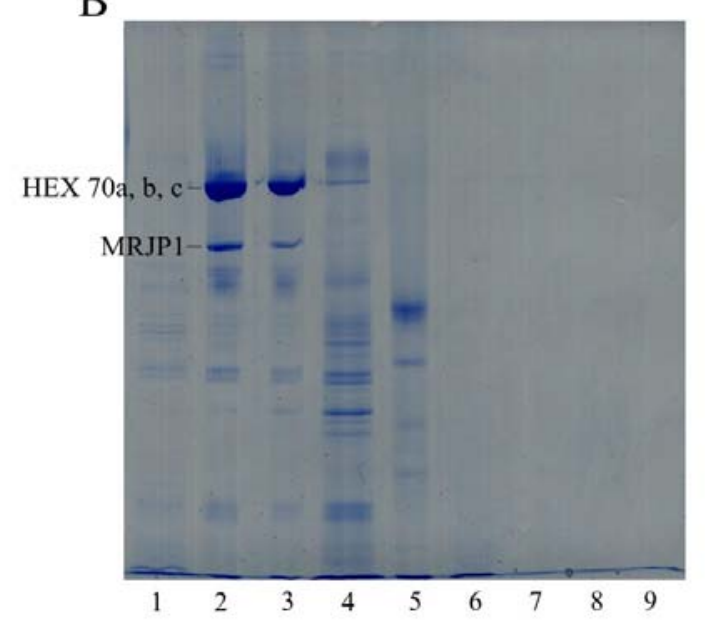

$\mathrm{C}$

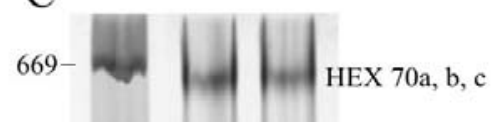

$440-$

$232-$

$158-1-1-M R J P 1$

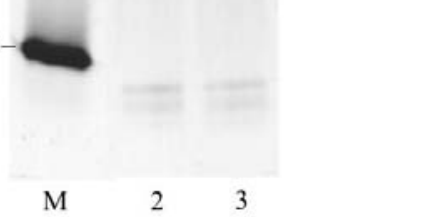

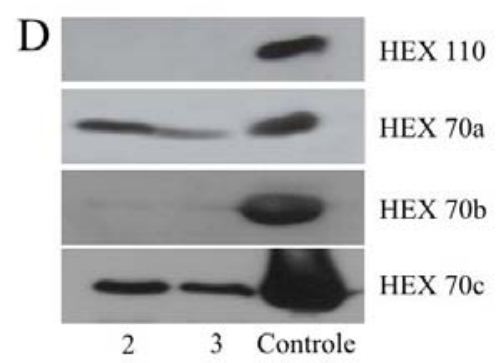

Figura 23: Cromatografia por filtração em gel. (A) Cromatograma. Os números indicam as frações coletadas. (B) SDS-PAGE de amostras das frações 1 a 9 obtidas da cromatografia. As subunidades HEX 70a, HEX 70b e HEX 70c estão indicadas, assim como a banda de aproximadamente $200 \mathrm{kDa}$ identificada como Major Royal Jelly Protein 1 (MRJP1). (C) PAGE em condições não-desnaturantes de amostras das frações 2 e 3 obtidas da cromatografia. (D) SDS-PAGE e Western blot de amostras das frações 2 e 3 utilizando-se anticorpos contra cada uma das quatro hexamerinas. 
Para melhor purificação dos oligômeros de hexamerinas obtidos nas frações 2 e 3 da cromatografia por filtração em gel, estas foram submetidas a cromatografia de alta-eficiência por troca-iônica. O procedimento gerou 5 picos (Fig. 24A). Análises por SDS-PAGE (Fig. 24B), PAGE não desnaturante (Fig. 24C) e espectrometria de massa revelaram que o $1^{\circ}$ pico gerado, ou fração, relativo a proteínas que não aderiram à coluna, continha 3 hexamerinas, HEX 70a, HEX 70b e HEX 70c, e que HEX 70b e HEX 70c estavam também presentes no $2^{\circ}$ pico. Western blots de amostras das frações 1 e 2 confirmaram a presença de HEX 70a e HEX70c na fração 1, e de HEX 70c na fração 2 (Fig. 24D). A presença de HEX 70b e HEX $70 \mathrm{c}$ no $2^{\circ}$ pico sugere a formação de um provável heteroligômero, ou seja, um hexâmero composto por estas duas subunidades. A proteína MRJP1 foi identificada nos picos 3, 4 e 5 . 
A
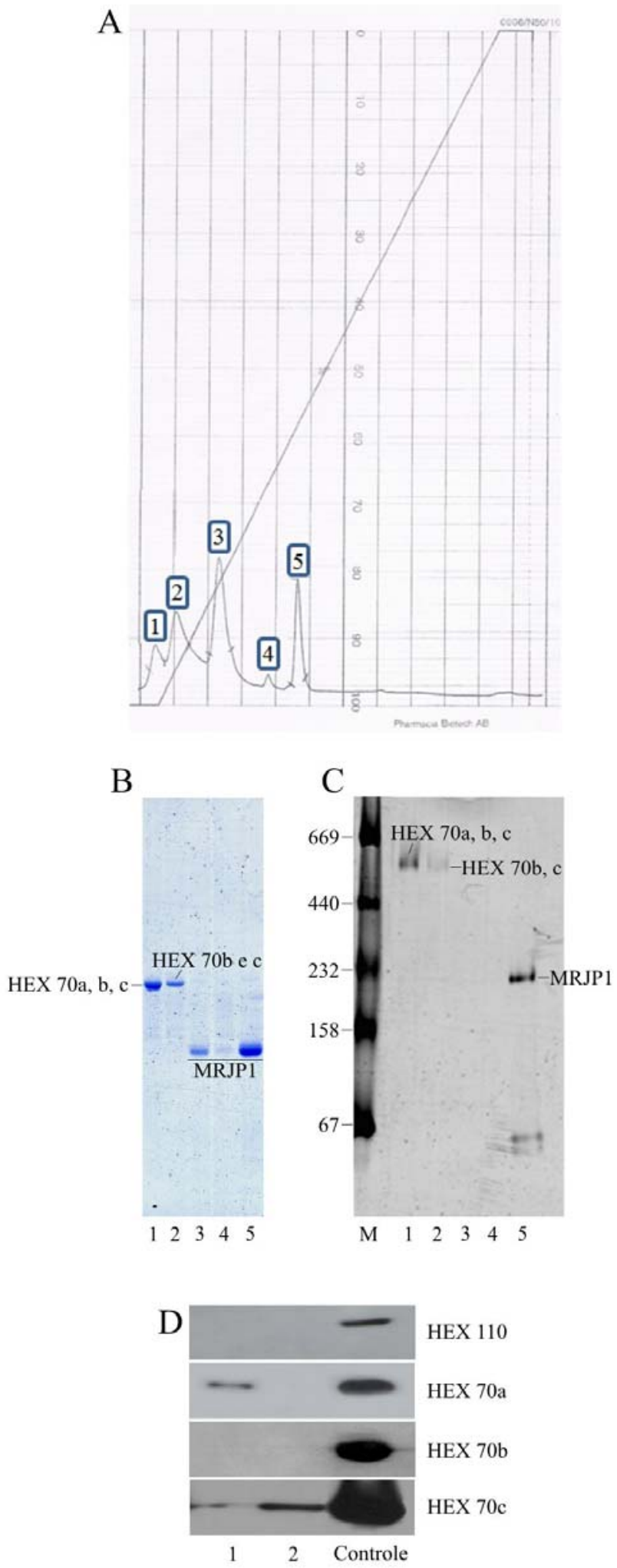

Figura 24: Cromatografia por troca-iônica das frações 2 e 3 obtidas da cromatografia por filtração em gel (ver Fig. 23). (A) Cromatograma. Os números indicam as frações coletadas. (B) SDS-PAGE de amostras das frações 1 a 5 obtidas da cromatografia. (C) PAGE não desnaturante de amostras das frações 1 a 5 obtidas da cromatografia. (D) Western blot de amostras das frações 1 e 2 utilizando-se anticorpos contra cada uma das quatro hexamerinas. 


\section{Produção das hexamerinas in vitro}

Como alternativa para a tentativa de separação e purificação das hexamerinas por cromatografia, partimos para a expressão in vitro destas proteínas. Foram construídos primers específicos para esta finalidade, os quais foram eficientes em amplificar esses genes (Fig. 25A). A Fig. 25B mostra a eficiência da digestão e a Fig. 25C mostra que as bactérias foram transformadas e contêm os insertos dos genes de hexamerinas. SDS-PAGE do extrato de bactérias após indução da expressão da proteína HEX 70c mostrou uma banda indicativa da expressão desta proteína (Fig. 25D). Testes por western blot para identificação desta banda no purificado estão em andamento. A expressão e a purificação das outras subunidades de hexamerinas estão em andamento.

A

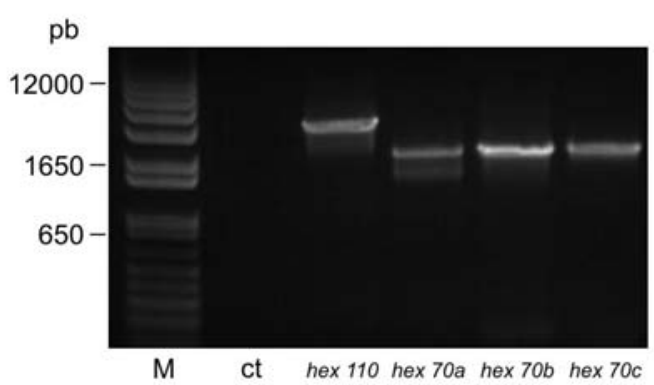

C

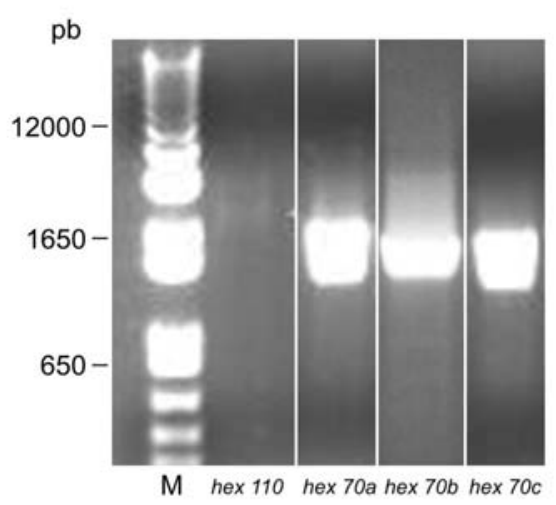

B

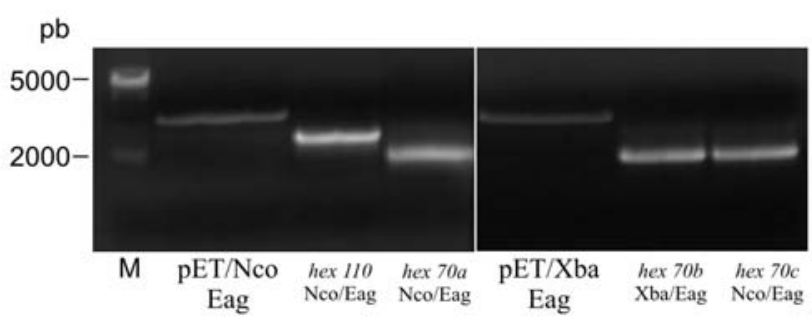

D

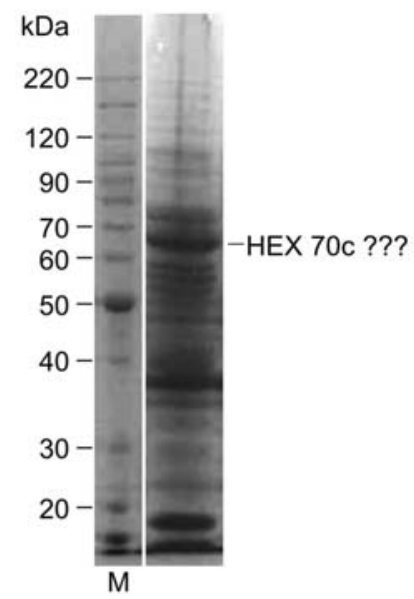

Figura 25: Expressão in vitro das quatro hexamerinas (HEX 110, HEX 70a, HEX 70b e HEX 70c). (A) Expressão dos genes hex 110, hex 70a, hex 70b e hex 70c obtida por RT-PCR semi-quantitativa seguida de eletroforese em gel de agarose $0,8 \%$, corado com brometo de etídio. M: marcador de massa molecular. $\mathrm{Ct}$ : amostra sem cDNA. (B) Produto de digestão dos genes amplificados, assim como do plasmídio pET-28a. Produto de PCR submetido a eletroforese em gel de agarose $0,8 \%$, corado com brometo de etídio. (C) PCR de extratos das colônias DH5a que foram transformadas com os plasmídeos contendo os genes de hexamerinas. Produto de PCR semi-quantitativa em gel de agarose $0,8 \%$, corado com brometo de etídio. (D) SDS-PAGE do extrato de bactérias BL21 após indução da expressão da proteína HEX 70c. 


\section{Busca pelos receptores de hexamerinas}

\subsection{Análises in silico de sítios de fosforilação putativos nas hexamerinas preditas}

Análises das sequências preditas das hexamerinas de A. mellifera utilizando-se o programa NetPhos 2.0 (www.cbs.dtu.dk/services/NetPhos/) revelaram a presença de sítios de fosforilação por tirosina quinase (Tabela VIII). Quanto maior o valor de score, que varia de 0 a 1, maior a probabilidade da sequência analisada constituir um sítio autêntico de fosforilação (Blom et al., 1999). Para as hexamerinas, o threshold adotado foi de 0,7 a 1. 
Tabela VIII: Sítios putativos de fosforilação nas sequências preditas de hexamerinas de A. mellifera.

\begin{tabular}{|c|c|c|}
\hline Nome & Fragmento & Score \\
\hline \multirow[t]{6}{*}{ HEX 110} & FPPVYEILP & 0,886 \\
\hline & KDIDYENVQ & 0,984 \\
\hline & FTDFYVDLD & 0,976 \\
\hline & QEPFYITEP & 0,939 \\
\hline & SVDQYQQLK & 0,900 \\
\hline & VSEYYQNKP & 0,949 \\
\hline \multirow[t]{11}{*}{ HEX 70a } & NIDSYTNAA & 0,943 \\
\hline & NEAQYIYSL & 0,854 \\
\hline & RGEEYLYSH & 0,798 \\
\hline & IDSGYILNN & 0,761 \\
\hline & NTEFYGSID & 0,809 \\
\hline & AASKYQIVP & 0,913 \\
\hline & DEIIYPNLK & 0,922 \\
\hline & IGPKYDSHH & 0,783 \\
\hline & SEIFYEKIE & 0,923 \\
\hline & DKPLYDFNY & 0,962 \\
\hline & YDFNYEGPN & 0,819 \\
\hline \multirow[t]{6}{*}{ HEX 70b } & MKKTYNNID & 0,726 \\
\hline & GEVSYVSLD & 0,973 \\
\hline & HMQKYVQMI & 0,918 \\
\hline & SNVKYQVVP & 0,968 \\
\hline & LGPKYDEFG & 0,806 \\
\hline & ETFKYSSQP & 0,839 \\
\hline \multirow[t]{9}{*}{ HEX 70c } & NMDMYKDKN & 0,982 \\
\hline & SEQKYEVRM & 0,954 \\
\hline & FELLYNAKD & 0,723 \\
\hline & PDTKYMKFP & 0,965 \\
\hline & VNTNYSSKN & 0,805 \\
\hline & NMREYNDPE & 0,783 \\
\hline & NDPEYKLDY & 0,868 \\
\hline & SSSQYHMPK & 0,865 \\
\hline & YKYKYLNVI & 0,810 \\
\hline
\end{tabular}

\subsection{Busca por hexamerinas em amostras de concentrados de membranas do corpo gorduroso}

Investigamos a possibilidade das hexamerinas de A. mellifera se ligarem à membrana plasmática. Análises por western blot com enriquecidos de membranas celulares do corpo 
gorduroso de operárias pupas faratas (fase PP) revelaram a presença marcante da HEX 110 e vestígios de HEX 70b e HEX 70c. HEX 70a não foi detectada (Fig. 26).

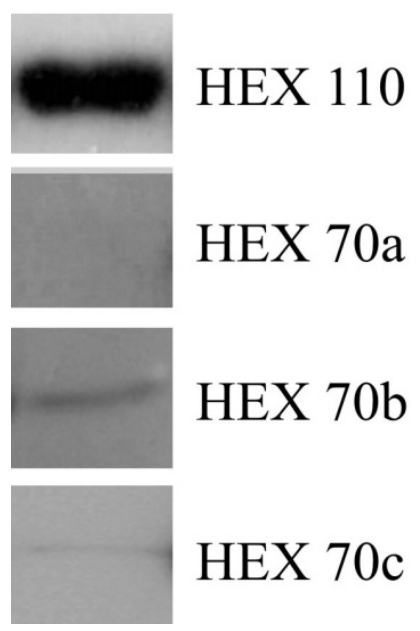

\subsection{Teste de ligação de hexamerinas em extratos enriquecidos de membranas do corpo gorduroso}

Amostras de extratos enriquecidos de membranas do corpo gorduroso de larvas L5F, pupas faratas (PP) e adultos faratos (Pbl) foram submetidas a SDS-PAGE (Fig. 27A). Os géis foram corados com Coomassie para verificar a eficiência do processo de extração das proteínas. Alíquotas das mesmas amostras foram utilizadas em procedimentos paralelos de SDS-PAGE seguidos de transferência das proteínas para membranas de PVDF por western blot. As membranas foram, então, incubadas com hemolinfa coletada de larvas L5F de operárias que apresenta alto conteúdo de hexamerinas. O intuito for verificar possível afinidade entre proteínas do extrato de membranas e proteínas solúveis da hemolinfa (Fig. 27B). Os resultados obtidos revelaram que HEX 110 da hemolinfa se liga a uma proteína de aproximadamente $110 \mathrm{kDa}$ presente no extrato de membranas (Fig. 27B). A marcação é mais intensa em pupas faratas, fase de intenso sequestro de hexamerinas pelas células do corpo gorduroso (Fig. 27B). HEX 70a da hemolinfa se ligou a duas proteínas do extrato de membranas (Fig. 27C) com massas moleculares ao redor de $70 \mathrm{kDa}$. A marcação é mais acentuada nas larvas L5F, fase anterior ao início do sequestro de hexamerinas pelo corpo gorduroso (Fig. 27C). HEX 70b se ligou a uma proteína de aproximadamente $70 \mathrm{kDa}$, aparentemente exclusiva da fase PP (Fig. 27D).

A eletroforese (SDS-PAGE) foi então repetida com amostras do extrato de membranas. Em seguida ao procedimento de coloração com Coomassie coloidal, o gel contendo as bandas obtidas dos extratos de membranas foi comparado com as membranas 
obtidas dos western blots com a finalidade de recortar do gel as bandas correspondentes. As proteínas das bandas foram identificadas por espectrometria de massa (Fig. 27E). Os resultados das análises revelaram a presença das três subunidades de hexamerinas HEX 110, HEX 70b e HEX 70c nas amostras de extratos enriquecidos de membranas. Além disso, proteínas como a endoplasmina (componente do retículo endoplasmático envolvido na degradação das proteínas em processo dependente de ubiquitinas) e uma heat shock protein de $60 \mathrm{kDa}$ também foram identificadas.

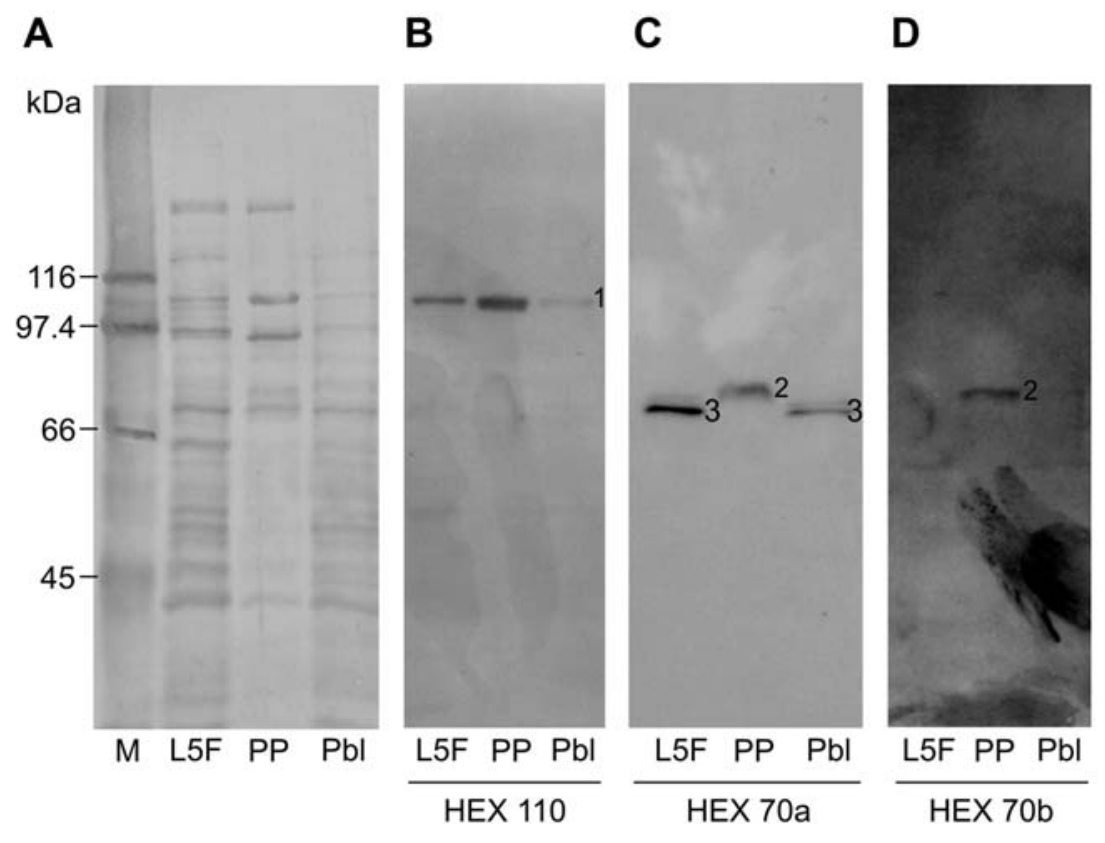

\begin{tabular}{cl} 
E & \\
\hline Amostra & \multicolumn{1}{c}{ MS identificação } \\
\hline 1 & HEX 110 \\
2 & HEX 70c e HEX 70b \\
3 & HEX 70b e heat shock protein $60 \mathrm{kDa}$ \\
\hline
\end{tabular}

Figura 27: Ligantes de hexamerinas em amostras de enriquecido de membranas de corpo gorduroso. (A) SDSPAGE do extrato de membranas do corpo gorduroso. SDS-PAGE seguido de western blot para as hexamerinas (B) HEX 110, (C) HEX 70a e (D) HEX 70b. M: marcador de peso molecular (kDa) no lado esquerdo da figura (A). L5F: larva de $5^{\circ}$ instar em fase de alimentação. PP: pupa farata. Pbl: adulto farato. Os números de 1 a 3 indicam as bandas analisadas por espectrometria de massa. (E) Resultado obtido por espectrometria de massa. 


\section{Discussão}

O genoma de A. mellifera apresenta quatro genes codificadores de hexamerinas. Estes genes foram sequenciados e a abundância de seus transcritos durante o desenvolvimento das diferentes castas e sexos foi caracterizada (Cunha et al., 2005; Martins et al., 2008; Martins et al., 2010). As sequências nucleotídicas obtidas revelaram diferenças estruturais e de organização de íntrons e éxons que, em conjunto com os perfis de mRNAs, a localização subcelular das hexamerinas no corpo gorduroso e nas gônadas, o estudo da regulação hormonal e nutricional, além da análise da estrutura das proteínas, indicam que as hexamerinas são proteínas multifuncionais, ressaltando sua importância no desenvolvimento e fisiologia dos insetos.

\section{Hexamerinas no corpo gorduroso}

Em concordância com estudos prévios sobre as proteínas da hemolinfa de A. mellifera (Danty et al., 1998; Chan et al., 2006), baixos níveis de expressão dos genes de hexamerinas foram detectados em operárias adultas quando comparados com os níveis de transcritos obtidos em larvas. Dos quatro genes de hexamerinas, hex 70a e hex 110 são os únicos com expressão detectável no corpo gorduroso de adultos. Seus perfis transcricionais diferem entre os adultos de rainhas, zangões e operárias. Níveis de transcritos de hex $70 a$ foram muito baixos em rainhas e abundantes em operárias e zangões. Entretanto, em zangões, a abundância é limitada aos 5 primeiros dias após a emergência, já em operárias, se estende até o $30^{\circ}$ dia de vida adulta. Estes perfis transcricionais em operárias e zangões são similares aos respectivos perfis de HEX 70a na hemolinfa (Martins et al., 2008) e estão relacionados com a duração da vida adulta. Operárias vivem mais que zangões (Winston, 1991) e seus respectivos padrões de expressão de hex $70 a$ refletem a atividade metabólica do corpo gorduroso. Mas a maior expressão de hex 70a no corpo gorduroso de operárias adultas, em comparação com rainhas, sugere função na físiologia das operárias.

Assim como hex 70a, o gene hex 110 está ativo no corpo gorduroso de operárias adultas, mas os transcritos são praticamente ausentes em rainhas e zangões. Apesar da evidente presença de transcritos de hex 110 em operárias adultas, a subunidade correspondente (HEX 110) não é detectável na hemolinfa (Bitondi et al., 2006), indicando que esta hexamerina não funciona como uma proteína de estocagem neste estágio.

Estes resultados são consistentes com a reindução da expressão de hex $70 a$ e de hex 110 nas abelhas adultas, embora só o produto de hex 70a se acumule na hemolinfa neste estágio. A presença de hexamerinas nos insetos adultos pode ocorrer por causa da persistência 
de hexamerinas sintetizadas durante o estágio larval, ou devido a indução da atividade gênica especificamente no estágio adulto. Como exemplo, algumas espécies de Lepidoptera que não se alimentam de proteínas na fase adulta podem utilizar o estoque larval de hexamerinas para a produção dos ovos (Wheeler et al., 2000); mRNAs para uma hexamerina específica de adultos aparece em fêmeas de Musca domestica só depois da indução por uma dieta rica em proteínas (Capurro et al., 2000). Mas a presença de HEX 70a em abelhas adultas resulta da reindução depois de uma drástica redução dos níveis de transcritos durante a ecdise adulta (Martins et al., 2010).

As rainhas de A. mellifera recebem continuamente, via trofalaxis, uma secreção glandular proteinácea, a geleia real, que é produzida por operárias nutridoras (Haydák, 1970). As rainhas aparentemente não necessitam da reserva de hexamerinas larvais para a produção de seus ovos, uma vez que a dieta enriquecida de proteínas pode suprir esta demanda. Os nutrientes estruturais e a energia derivados da geleia real servida às rainhas não são utilizados para a síntese e estocagem de hexamerinas (os níveis de transcritos de hexamerinas são muito baixos ou indetectáveis no corpo gorduroso de rainhas adultas) mas devem ser direcionados para a vitelogênese e produção dos ovos. Diferente das rainhas, as operárias normalmente não produzem ovos, embora elas tenham acesso a uma dieta rica em proteínas, pelo menos enquanto são jovens (Hrassnigg e Crailsheim, 1998). O consumo de pólen aumenta a expressão de hex 70a e hex 110 no corpo gorduroso e aumenta a abundância de HEX 70a na hemolinfa das operárias (Bitondi et al., 2006; Martins et al., 2008). Aparentemente, o consumo de dieta rica em proteínas causa a reindução de ambos os genes de hexamerinas em operárias adultas, levando à estocagem de HEX 70a na hemolinfa.

O consumo de pólen também provoca o acúmulo de vitelogenina, a proteína do vitelo, na hemolinfa de operárias jovens (Bitondi e Simões, 1996). A vitelogenina é continuamente produzida e estocada na hemolinfa durante as duas primeiras semanas de vida adulta, mas sua concentração na hemolinfa se reduz consideravelmente nas operárias mais velhas que se tornam forrageiras (Rutz et al., 1976; Engels et al., 1990; Hartfelder e Engels, 1998; Piulachs et al., 2003). HEX 70a segue um padrão similar.

Uma vez que as operárias normalmente não se reproduzem e, em geral, têm um ciclo de vida curto, a questão que permanece sem resposta é: por que elas estocam proteínas na hemolinfa? Podemos sugerir que o consumo de pólen pelas abelhas operárias jovens excede a demanda e o excesso é transformado em proteínas de estocagem e outros produtos para serem consumidos mais tarde, quando elas se tornarem forrageiras. Forrageiras se alimentam de néctar (Crailsheim et al., 1992), o qual é composto primariamente por carboidratos (Slansky e Scriber, 1985). Desta forma, o estoque de proteínas sustentaria o metabolismo basal das 
operárias durante o forragemanto. Os dados obtidos para HEX 70a (Martins et al., 2008), vitelogenina (Engels et al., 1990; Hartfelder e Engels, 1998; Piulachs et al., 2003) e outras proteínas da hemolinfa (Crailsheim, 1986), que mostram diminuição gradual da concentração destas proteínas nas forrageiras, são consistentes com esta hipótese.

O destino das proteínas de estocagem na hemolinfa de operárias pode não ser fixo, mas dependente do contexto social. Quando há perda da rainha, certas operárias podem ativar seus ovários para a produção de zangões. Suas reservas de proteínas podem então ser direcionadas para a reprodução. Operárias acumulam proteínas de estocagem quando elas ainda são jovens e mais propensas a ativar seus ovários se separadas das rainhas. Foi demonstrado que as operárias adultas de Camponotus festinatus não estocam hexamerinas, mas aparentemnte fazem uso delas para nutrir as larvas. Mas as hexamerinas se acumulam na hemolinfa destas operárias quando não há larvas na colônia. Também foi observado que as hexamerinas são abundantes em rainhas virgens de C. festinatus, mas tornam-se escassas quando elas estão produzindo ovos (Martinez e Wheeler, 1993 e 1994). O mesmo foi observado em cupins (Johnston e Wheeler, 2007).

Utilizando anticorpos específicos investigamos a localização das quatro hexamerinas nas células do corpo gorduroso de operárias no estágio de pupa farata. Neste estágio, a arquitetura típica do corpo gorduroso larval é modificada e as camadas ou aglomerados de células que formam este órgão se dissociam em células individuais (Hoshizaki, 2005). Esta mudança, que caracteriza o início da muda metamórfica nos insetos holometábolos e já foi descrita para A. mellifera (Snodgrass, 1956) e outras espécies de abelhas (Cruz-Landim, 2009; Poiani e Cruz-Landim, 2012), é marcada pela drástica diminuição da síntese/secreção de hexamerinas, para sua reabsorção da hemolinfa. Estudos que estabeleceram a correlação entre a diminuição de hexamerinas da hemolinfa e o aparecimento de grânulos no citoplasma dos trofócitos do corpo gorduroso anteciparam a demonstração experimental de que as hexamerinas sequestradas são estocadas na forma de grânulos para futura utilização como fonte de aminoácidos (Locke e Collins, 1968; Tojo et al., 1978). Esta dinâmica de síntese/secreção/sequestro foi deduzida quando comparamos os níveis de HEX 70b na hemolinfa e no corpo gorduroso de A. mellifera em metamorfose. Há uma diminuição abrupta de HEX 70b na hemolinfa de pupas faratas (fase PP) e aumento no corpo gorduroso (ver Fig. 4). Neste aspecto, HEX 70b é a mais típica entre as hexamerinas de A. mellifera. Embora esta dinâmica não seja tão evidente para as outras hexamerinas, todas elas aparecem no corpo gorduroso na fase que antecede a muda metamórfica (L5S) indicando que estão sendo sequestradas. Como descrito para as hexamerinas dos insetos em geral, HEX 70b, HEX 70c e HEX 110 são essencialmente proteínas da metamorfose e sua abundância diminui a níveis 
basais antes da ecdise adulta. Entretanto, como demonstrado previamente (Danty et al., 1998; Martins et al., 2008) HEX 70a persiste até nos adultos (veja Fig. 4).

Utilizando-se anticorpos específicos e microscopia confocal, as hexamerinas foram localizadas em pequenas e grandes inclusões, similares aos grânulos de proteínas de diferentes tamanhos, no citoplasma dos trofócitos de pupas faratas. O aparecimento dos grânulos de proteínas no corpo gorduroso de A. mellifera antes da pupação foi descrito décadas atrás por Bishop (1922; 1923). Utilizando ilustrações esquemáticas, Snodgrass (1956) descreveu a localização destes grânulos na periferia do citoplasma dos trofócitos em pupas faratas de $A$. mellifera, e também comentou que a abundância destes grânulos de proteínas continua a aumentar durante parte do estágio pupal para desaparecer próximo à ecdise adulta. Poiani e Cruz-Landim (2012) também encontraram grandes quantidades de grânulos de proteínas nos trofócitos de pupas faratas. As inclusões, ou grânulos, marcados com anti-HEX 70c ou antiHEX 70b nos trofócitos foram principalmente localizados na periferia do citoplasma (ver Fig. 6G, I, J, L), assim como os grânulos descritos por Snodgrass (1956). Aparentemente, os grânulos marcados com anti-HEX 70b a anti-HEX 70c estão envolvidos na estocagem e reciclagem de HEX 70b e HEX 70c. Grânulos marcados com anti-HEX 110 e anti-HEX 70a foram muito menos abundantes nos trofócitos, mas isto pode ser devido à regionalização do corpo gorduroso. Já foi demonstrado em $D$. melanogaster que a abundância de grânulos de proteínas pode diferir entre as regiões do corpo gorduroso (Tysell e Butterworth, 1978). Os trofócitos mostrados na Fig. 6 podem ser de diferentes regiões do corpo da pupa farata.

Como proposto (Locke e Collins, 1968), pequenos grânulos de proteínas são inicialmente formados nos trofócitos e mais tarde se fundem com outros grânulos e aumentam de tamanho. É então possível que nos trofócitos mostrados nas Fig. 6A (marcados com antiHEX 110) e 6D (marcados com anti-HEX 70a) a fusão dos grânulos de proteína tenha apenas se iniciado no momento da coleta do corpo gorduroso.

A presença de hexamerinas no citoplasma dos trofócitos era uma expectativa óbvia, mas nós encontramos pequenas marcações destas hexamerinas no citoplasma dos enócitos. Enócitos diferem dos trofócitos quanto à origem embriológica, morfologia, funções bioquímicas e fisiológicas, sendo necessários para o processamento de lipídeos, crescimento larval e produção de feromônios (Hoshizaki, 2005; Burns et al., 2012). Foi uma surpresa encontrar hexamerinas nos enócitos. Notável, entretanto, foi detectar as quatro hexamerinas no núcleo dos trofócitos, e HEX 110 e HEX 70a no núcleo dos enócitos. A imunolocalização das hexamerinas no núcleo do corpo gorduroso através de microscopia confocal confirmou os resultados obtidos por western blot (Fig. 5), que tinham detectado as quatro hexamerinas em frações de enriquecidos nucleares do corpo gorduroso. 
Corroborando nossos dados sobre a licalização intranuclear das hexamerinas, Begna et al. (2012) detectaram HEX 110 no proteoma nuclear de larvas de rainhas e operárias de $4^{\circ} \mathrm{e}$ $5^{\circ}$ ínstares, utilizando eletroforese bidimensional e espectrometria de massa.

Aqui, nós também mostramos que a injeção de anticorpos contra cada hexamerina na hemocele de operárias em início do desenvolvimento adulto farato provoca diminuição parcial ou total da concentração de hexamerinas na hemolinfa ou no corpo gorduroso, 4 e/ou $24 \mathrm{~h}$ após a injeção. A injeção de cada anticorpo não resultou em mortalidade significante em comparação aos controles. Entretanto, a ecdise para o estágio adulto foi antecipada. Esta resposta ocorreu independentemente do tipo de anticorpo anti-hexamerina injetado, evidenciando a importância de cada hexamerina no tempo de desenvolvimento do adulto farato.

Como pupas e adultos faratos não se alimentam, o seu desenvolvimento é viabilizado por estoques endógenos de nutrientes acumulados durante o estágio larval. Hexamerinas são as principais proteínas de estocagem na hemolinfa larval e a principal fonte de aminoácidos para o desenvolvimento pupal e adulto farato. Funcionando como um fator nutricional, a diminuição natural dos níveis de hexamerinas na hemolinfa e corpo gorduroso pode ter uma função crítica na sinalização do início da ecdise adulta. É possível que a diminuição dos níveis de hexamerinas nos adultos faratos tratados com anticorpo tenha de algum modo antecipado a ecdise em resposta à restrição de aminoácidos derivados das hexamerinas.

Sabe-se que o status nutricional das larvas tem importante função no controle do seu tamanho e início da muda metamórfica (Callier e Nijhout, 2011). O iníco da muda metamórfica depende de um tamanho limite, ou peso crítico, em que os eventos endócrinos levam ao término da alimentação larval e início da metamorfose (Davidowitz et al., 2003; Nijhout et al., 2006). Pode-se hipotetizar que um sinal nutricional também controle o tempo do desenvolvimento do adulto farato até a ecdise, o qual pode ter sido perturbado pela diminuição dos níveis de proteínas de estocagem.

\section{Hexamerinas nas gônadas}

\subsection{Ovários}

\subsubsection{HEX 70a}

Entre os insetos solitários há evidências circunstanciais de que as hexamerinas também são utilizadas para a reprodução. Em espécies de Lepidoptera, por exemplo, foi estabelecida a correlação entre a produção de ovos e a diminuição das reservas de hexamerinas (Pan e Telfer, 1996; Wheeler et al., 2000). Mosquitos autógenos, que produzem 
sua primeira leva de ovos sem se alimentar, podem utilizar as proteínas de estocagem larvais, principalmente as hexamerinas, como fonte de aminoácidos para esta finalidade (Wheeler e Buck, 1996; Zakharkin et al., 2001). Também foi sugerido que os aminoácidos provenientes das proteínas de estocagem são utilizados para prover os ovos de Schistocerca americana (Hahn e Wheeler, 2003).

Utilizando western blots, Martins et al. (2010) investigaram a presença de transcritos de hexamerinas nas gônadas de A. mellifera. Exceto para hex 70c, os transcritos foram abundantes nas gônadas de larvas e pupas de operárias, rainhas e zangões, sugerindo que hexamerinas têm função na diferenciação dos ovários e também na espermatogênse, que ocorre durante o estágio pupal e é finalizada antes da emergência do zangão. Dois dos genes de hexamerinas, hex 70a e hex 110, também mostraram-se expressos em ovários de rainhas adutas. Transcritos de hex 110 foram mais abundantes nos ovários de rainhas ovipositoras do que em rainhas virgens.

Sabe-se que o acasalamento provoca mudanças na expressão dos genes de fêmeas de Drosophila (McGraw et al., 2004). O acasalamento também provoca mudanças fisiológicas e de comportamento nas rainhas de A. mellifera, e embora os mecanismos moleculares envolvidos nesta resposta não sejam conhecidos, foi verificado que eles envolvem expressão diferencial de genes nos ovários. Baseado nisto, a estes genes diferencialmente expressos foram atribuídas funções na ovogênese (Kocher et al., 2008). O aumento de expressão de hex 110 nos ovários de rainhas ovipositoras sugere uma função relacionada à atividade ovariana e reprodução.

Ovários de rainhas ovipositoras têm menores níveis de transcritos de hex 70a que ovários de rainhas recém-emergidas. Mas subunidades de HEX 70a existem em quantidade equivalente nos ovários de ambas, rainhas recém-emergidas e ovipositoras, como confirmado por western blot utilizando anticorpo específico (Martins et al., 2008). É possível que assim como a vitelogenina (principal proteína do vitelo dos ovos) que é secretada na hemolinfa e incorporada aos ovários, parte das hexamerinas dos ovários resulte de sequestro dos estoques da hemolinfa.

Nossos procedimentos de imunolocalização por microscopia confocal mostraram que HEX 70a está localizada no núcleo de células germinativas e somáticas dos ovários e testículos. Esta localização, inesperada para uma proteína de estocagem, implica em funções regulatórias e estruturais nos núcleos. É a primeira vez que uma hexamerina é detectada no núcleo, HEX 70a cumpre todos os critérios para sua inclusão na classe das hexamerinas. Ela apresenta os três domínios de hemocianinas que são típicos de todas as hexamerinas. Ela é maciçamente sintetizada pelo corpo gorduroso durante o estágio de alimentação larval e 
abundantemente estocada na hemolinfa (Danty et al., 1998; Martins et al., 2008). Esta característica está em conformidade com a função das hexamerinas prover aminoácidos para o desenvolvimento pupal e adulto farato.

Em sua estrutura nativa, HEX 70a é um oligômero (ver item III 2 - Resultados) e pode atuar no núcleo na forma monomérica, como recentemente demonstrado para a royalactin, um monômero de $57 \mathrm{kDa}$ que funciona como um fator determinante de casta em A. mellifera. Royalactin forma o oligômero MRJP1, um membro da família das Major Royal Jelly Proteins, que está presente não só na geleia real secretada pelas glândulas hipofaríngeas das operárias, mas também na hemolinfa e em outros tecidos de A. mellifera (Kamakura, 2011).

A colocalização nuclear de HEX 70a com o marcador da fase $\mathrm{S}$ do ciclo celular (EdU) indicou que a HEX 70a pode ter função na replicação do DNA para a proliferação celular ou poliploidização. Esta hipótese é apoiada por dados da literatura. Foi demonstrado que o corpo gorduroso ou extratos de corpo gorduroso (de espécies de Lepidoptera) são capazes de estimular a proliferação de células tronco intestinais em sistema in vitro (Loeb e Hakim, 1996; Sadrud-Din et al., 1996). Curiosamente, o fator do corpo gorduroso que induz a proliferação celular foi identificado como sendo uma subunidade de arilforina de $77 \mathrm{kDa}$ ( $\alpha$-arilforina) (Blackburn et al., 2004). Baixa concentração de $\alpha$-arilforina purificada foi suficiente para estimular a proliferação das células tronco intestinais, excluindo um simples efeito nutricional. Experimentos usando marcação com BrdU confirmaram que a arilforina induz a síntese de DNA. A atividade de estimulação mitogência da arilforina foi também detectada in vivo em insetos que mostraram um aumento nas taxas de crescimento depois de serem alimentados com uma dieta artificial contendo a arilforina (Blackburn et al., 2004; Cermenati et al., 2007). Portanto, metodologias experimentais muito distintas daquelas utilizadas nesta tese, nos levam a mesma conclusão, ou seja, que as arilforinas têm função na proliferação celular.

Verificamos também núcleos de células dos ovaríolos que mostraram imunofluorescência para HEX 70a, mas não para EdU (o reverso não foi observado). Isto pode indicar que HEX 70a não tem função exclusiva na fase $\mathrm{S}$ do ciclo celular, ou que a estabilidade da proteína no interior do núcleo não é restrita à fase $\mathrm{S}$. A hipótese de que HEX 70a está envolvida na proliferação celular foi reforçada pelos resultados dos experimentos onde o anticorpo anti-HEX 70a foi injetado em pupas faratas de rainhas, revelando um efeito negativo sobre a largura dos ovaríolos que aumentam de tamanho via proliferação celular.

HEX 70a foi localizada no núcleo dos cistócitos dos ovários de operárias em início da fase pupa farata. Cistócitos são mitoticamente ativos, como mostrado aqui por marcação com EdU, e através de marcação por BrdU (5-bromo-2'-deoxyuridine) (Tanaka e Hartfelder, 
2004). Cada cistócito prolifera para formar um clone de cerca de 48 ou mais células (Snodgrass, 1956; Büning, 1994) que se organiza como uma roseta e contém uma estrutura específica da linhagem germinativa, o polifusoma (Lin et al., 1994). A proteína actina foi identificada como sendo um proeminente componente do polifusoma no centro das rosetas (Gutzeit et al., 1993; Schimidt-Capella e Hartfelder, 2002). Um cistócito em cada roseta entrará em meiose e iniciará o crescimento e, então, se tornará morfologicamente distinguível das células dos cistócitos destinadas a serem nutridoras (nurse cells). As rosetas são gradualmente transformadas em folículos iniciais, com o fusoma sendo convertido em canais em anel que conectam o ovócito em desenvolvimento com as células nutridoras, e estas células entre si. Cada cluster de ovócito e células nutridoras é envolvido pelas células foliculares e serão divididos em câmara do ovo, onde a ovogênese e vitelogênese acontecem, e uma câmara trofocítica (ou câmara das células nutridoras) (Büning, 1994; Tanaka e Hartfelder, 2004; Wilson et al., 2011). Enquanto este padrão é comum em rainhas, a progressão da ovogênese em operárias só ocorrerá se elas forem liberadas do efeito repressor do feromônio da rainha (Page e Erickson, 1988).

As células nutridoras passam por uma série de ciclos endomitóticos (Büning, 1994; Cruz-Landim, 2009). Esta característica, típica de um ovário meroístico, é uma estratégia evolutiva para aumentar a síntese de material a uma taxa elevada durante a ovogênese, e exportá-los para o ovócito em crescimento por meio dos canais em anel (Engels, 1968; Spradling, 1993). Durante a ovogênese de A. mellifera, as células foliculares se transformam em um espesso epitélio ao redor do ovócito em crescimento e em uma camada de células achatadas ao redor do agrupamento de células nutridoras (Fleig et al., 1991). Para acompanhar o intenso crescimento do ovócito durante a ovogênese e vitelogênese, as células foliculares que o circundam passam por diversos ciclos de divisões mitóticas. Dados de nosso laboratório (Macedo LMF, comunicação pessoal) revelaram significante aumento do número de células foliculares conforme o ovócito se desenvolve. Consistente com uma função na replicação de DNA, HEX 70a foi localizada no núcleo das células foliculares em proliferação que recobrem o ovócito em crescimento em ovários de rainhas. O padrão de marcação de HEX 70a nos núcleos difere entre as células nutridoras e foliculares. Os foci de HEX 70a se assemelham a pequenos pontos distribuídos por todo o núcleo das células nutridoras e são maiores e concentrados em áres nucleares bem definidas nas células foliculares. HEX 70a também foi localizada no núcleo das células do filamento terminal, onde foi demonstrada a presença de células em divisão (Tanaka e Hartfelder, 2004), provavelmente células tronco da linhagem germinativa. Só nesta região do ovaríolo pudemos distinguir marcação de HEX 70a 
no citoplasma. Não obtivemos êxito em localizar HEX 70a no núcleo dos ovócitos em meiose.

A presença de HEX 70a no núcleo das células germinativas e somáticas de ovários sugere função na regulação, organização estrutural nuclear e/ou proliferação celular.

Aqui é preciso considerar que em contraste às células dos ovários que são mitoticamente ativas, como mostrado por marcação com BrdU (5-bromo-2'-deoxy-uridine) (Tanaka e Hartfelder, 2004) e também com EdU, as células do corpo gordurose de pupas faratas não estão se dividindo, mas estão em processo de dissociação para a metamorfose. Qualquer que seja a função das hexamerinas no núcleo das células do corpo gorduroso de pupas faratas, certamente não está relacionada à proliferação celular. Uma proteína de estocagem de Bombyx mori (SP2), que apresenta cerca de $25-30 \%$ de similaridade com as hexamerinas de A. mellifera suprimiu a fragmentação nuclear e formação de corpos apoptóticos em cultivos de células HeLa (Rhee et al., 2007). Este intrigante resultado pode indicar que durante a metamorfose, as hexamerinas protegem certas células do corpo gorduroso da morte celular programada, mas isto tem que ser ainda investigado

\subsubsection{HEX 110}

Estudos prévios (Martins et al., 2010), utilizando RT-PCR semi-quantitativa e quantitativa, indicaram a presença de mRNA do gene hex 110 nos ovários de rainhas ovipositoras, sugerindo possível função desta proteína durante o processo reprodutivo. Os procedimentos de imunolocalização e microscopia confocal confirmaram marcações de HEX 110 no filamento terminal, germário e vitelário de ovários de rainhas ovipositoras. HEX 110 foi visualizada no núcleo e citoplasma das células do filamento terminal e região proximal do germário, locais onde se encontram os precursores das células foliculares e germinativas. A presença de pontes intercelulares e de centríolos no filamento terminal sugerem a ocorrência de proliferação celular (Cruz-Landim, 2009) e isto reforça a observação de Tanaka e Hartfelder (2004) em seus experimentos de marcação de ovários com BrdU.

Conforme o ovócito cresce no ovário da rainha e as câmaras nutridoras e ovocíticas vão se diferenciando na região do vitelário, a hexamerina HEX 110 passa a ser detectada apenas no citoplasma das células foliculares que circundam estas câmaras.

Em operárias adultas, transcritos de hex 110 não foram detectados nos ovários. Isto não exclui a possibilidade de transferência de HEX 110 da hemolinfa para os ovários, o que nos motivou a utilizar o anticorpo anti-HEX 110 em experimentos de imunolocalização nos ovários de operárias adultas. HEX 110 foi detectada no núcleo das células do filamento 
terminal, do germário e das células foliculares que envolvem a câmara ovocítica. Portanto, assim como HEX 70a, HEX 110 também se localiza no núcleo de células dos ovários.

No filamento terminal e na região proximal do germário, HEX 110 aparentemente localiza-se nos nucléolos. Mas esta marcação não é mais observada nos folículos em crescimento. Os nucléolos desaparecem dos ovários de Drosophila melanogaster, quando os ovócitos passam a ter alguma atividade transcricional (Liu et al., 2006) que ocorre durante o crescimento do ovócito conforme demonstrado por marcações com BrdU (Bogolyubov, 2007). É possível que a não detecção de HEX 110 nos núcleos de folículos em crescimento deva-se ao desaparecimento dos nucléolos, mas isto tem que ser mais profundamente investigado.

\subsection{Testículos}

A localização intranuclear de HEX 70a também foi detectada nas células germinativas e somáticas da gônada masculina em desenvolvimento. Marcações citoplasmáticas de HEX 70a foram observadas somente nos estágios iniciais do desenvolvimento do testículo. Com o progresso da espermatogênese a marcação de HEX 70a se torna exclusivamente intranuclear. Este resultado se assemelha ao que ocorre nos ovários, onde HEX 70a se localiza no citoplasma de células do filamento terminal, que ainda não iniciaram a ovogênese, mas conforme os folículos crescem, passa a se localizar exclusivamente nos núcleos.

Nas pupas de zangões, os clusters de espermatogônias secundárias, também denominadas de cistócitos, são circundados por células somáticas ricas em actina. No interior destes cistos, as espermatogônias se tornam espermatócitos, que então iniciam a divisão meiótica (Louveaux, 1977). Dentro do cisto, as células germinativas estão conectadas por pontes citoplasmáticas, os canais em anel, similares àqueles vistos nos ovaríolos. Assim, a presença de HEX 70a nos núcleos dos cistócitos e das células somáticas dos zangões também pode estar associada à proliferação celular. Entretanto, HEX 70a também foi detectada no núcleo de espermátides e de espermatozoides que não estão em processo de proliferação.

Nos zangões de A. mellifera, o processo inteiro da espermatogênese, das células germinativas indiferenciadas até a formação do espermatozoide, ocorre durante o desenvolvimento pós-embrionário e é essencialmente concluído antes da emergência do zangão da célula de cria. Os espermatozoides então migram dos testíolos para as vesículas seminais onde são estocados por poucos dias antes do vôo para fecundar a rainha (Snodgrass, 1956). A espermatogênese em abelhas se caracteriza por (1) uma meiose atípica (zangões são originários de ovos haplóides) durante a qual os espermatozoides permanecem interconectados por pontes citoplasmáticas, (2) formação e subsequente eliminação dos 
centríolos excedentes derivados da primeira divisão meiótica, e (3) divisão desigual dos espermatócitos secundários (Hoage e Kessel, 1968).

Durante a espermatogênese em D. melanogaster, formam-se cistos de 64 espermátides interconectadas, derivadas de uma única célula germinativa precursora. Estas espermátides sinciciais são finalmente separadas em espermatozoides em um processo chamado de individualização, que ocorre simultaneamente para todas as 64 espermátides. A polimerização da actina é importante para a individualização, e este processo é mediado por cones de actina que se formam ao redor de cada núcleo dos espermatozoides. Os cones de actina adquirem um formato triangular e se movem para longe do núcleo do espermatozoide, provocando a formação do corpo residual que contém citoplasma e organelas que serão descartados. Este processo leva à transição das espermátides sinciciais para os espermatozoides individualizados (Noguchi e Miller, 2003).

Durante a espermatogênese de zangões detectamos marcação de HEX 70a no núcleo das espermátides sinciciais, posteriormente à localização dos cones de actina, e também no núcleo dos espermatozoides individualizados. A presença de HEX 70a no núcleo das espermátides em diferenciação e nos espermatozoides certamente não pode estar associada à proliferação celular, mas sugere uma nova e distinta função para esta proteína durante a espermatogênese.

\section{Hexamerinas e o HJ}

Os quatro genes codificadores de hexamerinas em $A$. mellifera são diferencialmente expressos nos diferentes morfotipos (operárias, rainhas e zangões) durante o período de transição larval-pupal (Martins, 2008; Martins et al., 2010). A diferença mais marcante ocorreu durante a fase de alimentação do $5^{\circ}$ instar larval (L5F), onde foram observados os maiores níveis de transcritos de hex 110, hex 70a e hex $70 b$ em operárias e zangões quando comparados aos de rainhas. Este é um resultado muito interessante se comparado com os títulos de HJ neste estágio, maiores em rainhas do que em operárias e zangões (Rembold, 1987; Rachinsky et al., 1990). Sabe-se que o HJ tem função central na diferenciação das castas em A. mellifera. Os títulos deste hormônio geram respostas fisiológicas específicas em larvas: altos títulos de $\mathrm{HJ}$ induzem o desenvolvimento de rainhas e baixos títulos de $\mathrm{HJ}$ especificam o fenótipo de operárias (Wirtz e Beetsma, 1972; Rembold et al., 1974). A relação inversa entre os níveis de transcritos de hexamerinas e os títulos de HJ leva-nos a especular se, como proposto para os cupins Reticulitermes flavipes (Zhou et al., 2006a e b; Zhou et al., 2007; Scharf et al., 2007), as hexamerinas de A. mellifera podem funcionar como proteínas ligadoras de HJ. Por se ligarem e controlarem os níveis de HJ, as hexamerinas desta espécie 
de cupim foram relacionadas ao processo de diferenciação de castas. Aplicando este modelo para A. mellifera, podemos hipotetizar que títulos altos de $\mathrm{HJ}$ excedem a capacidade de ligação das hexamerinas. Em consequência, o HJ livre interage com receptores específicos e promove o desenvolvimento da rainha. Com exceção de hex 70c, todos os genes de hexamerinas mostraram expressão significantemente maior em larvas de operárias L5F (apresentam baixos títulos de HJ) que em larvas de rainhas no mesmo estágio do desenvolvimento (apresentam altos títulos de HJ) (Martins, 2008; Martins et al., 2010). O $5^{\circ}$ instar larval é um período crítico para a determinação de castas em A. mellifera. Se as hexamerinas de fato se ligam ao HJ, também contribuem para a diferenciação da larva bipotente em rainha operária.

As hexamerinas podem não se ligar diretamente ao HJ, mas podem fazer parte de um complexo de proteínas envolvido no sequestro e transporte deste hormônio. A primeira demostração física desta interação entre o HJ e um complexo de proteínas revelou a presença de duas hexamerinas (uma delas é uma arilforina) e uma lipoforina, além da proteína específica de ligação ao HJ, JHBP (Juvenile hormone binding protein), neste complexo (Zalewska et al., 2009). Esta interação implica em importante participação das hexamerinas na regulação dos níveis e ação do HJ, mesmo não se ligando diretamente a ele.

A possibilidade das hexamerinas de A. mellifera, e de outros insetos, atuarem como proteínas ligadoras de $\mathrm{HJ}$, assim influindo na regulação dos níveis deste hormônio e, consequentemente, em aspectos essenciais do ciclo de vida, requer investigação. O primeiro passo nesta direção é a purificação parcial ou total das hexamerinas.

Além da hipotética função de "ligar" ao HJ, a expressão dos genes de hexamerinas de A. mellifera é induzida por este hormônio. Nossos resultados mostraram forte e positiva influência do HJ sobre a expressão dos genes hex $70 b$ e hex $70 c$, e um efeito mais sutil sobre a expressão de hex $70 a$ e hex 110. Estes resultados foram reforçados pela identificação, na região 5' UTR dos quatro genes de hexamerinas, de potencial sítio de ligação para a proteína Usp, a qual integra o complexo receptor de HJ (e ecdisteróides) (Martins et al., 2010). Estes dados indicam que o HJ regula a atividade dos genes de hexamerinas. A Fig. 28 resume os dois aspectos da relação entre as hexamerinas e o HJ. 


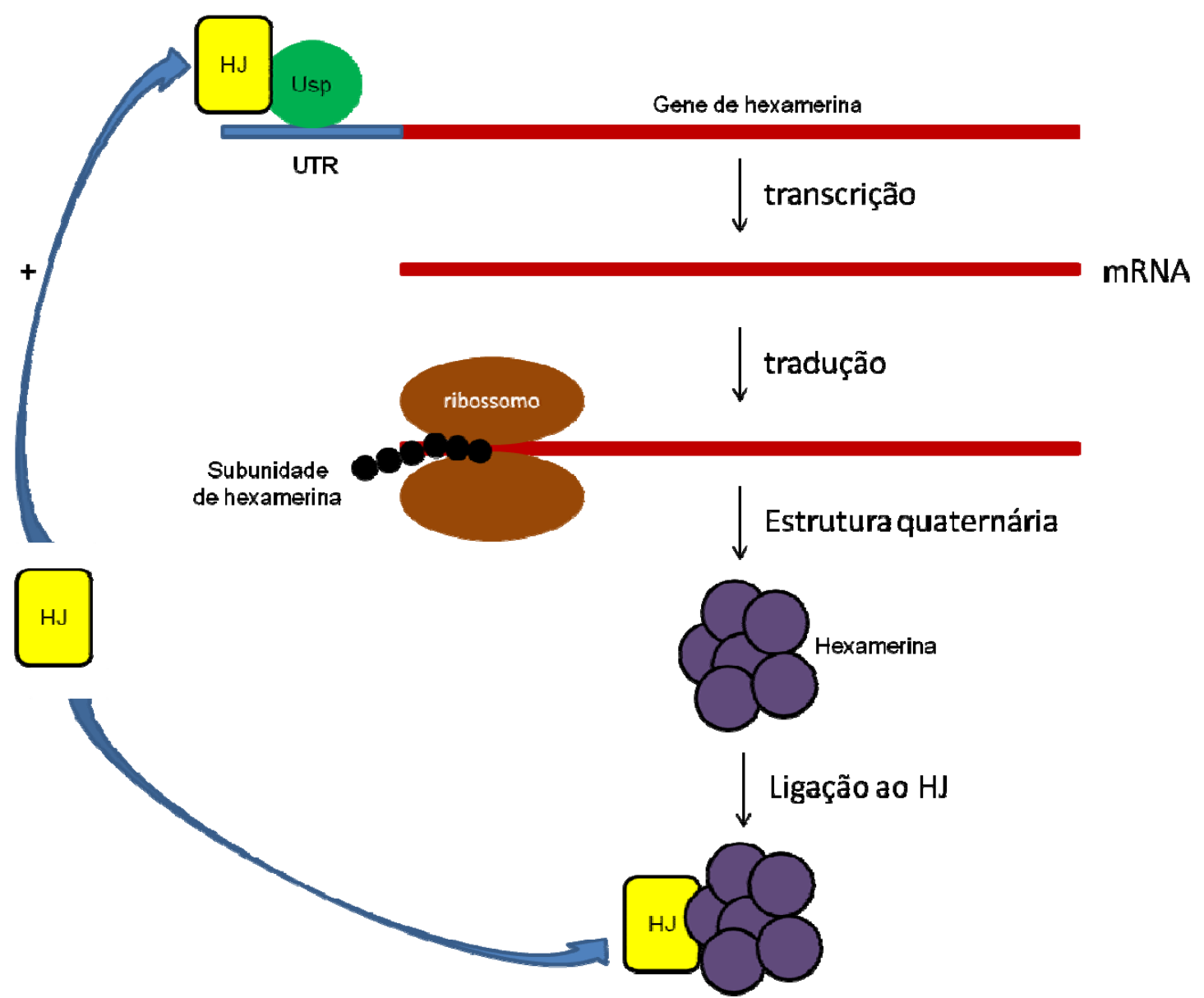

Figura 28: Esquema das possíveis relações entre o $\mathrm{HJ}$ e as hexamerinas de A. mellifera. O HJ em associação com a proteína Usp regula a transcrição dos genes de hexamerinas. As hexamerinas se ligam ao HJ modulando seus títulos e sua ação.

\section{Hexamerinas e formação da cutícula}

HEX 70a contém alta proporção de aminoácidos aromáticos (18,2\%), o que a torna um membro da subclasse das hexamerinas, as arilforinas, as quais têm sido relacionadas à formação da cutícula. Aminoácidos aromáticos são necessários para o processo de esclerotização do exoesqueleto (Munn et al., 1967; Webb e Riddiford, 1988; Wu e Tischler, 1995; Pan e Telfer, 1996 e 1999). Como demonstrado aqui, a inativação de HEX 70a in vivo pela injeção de anti-HEX 70a em pupas de operárias visivelmente interferiu no processo de formação da cutícula adulta e este efeito foi mais evidente na cutícula das pernas. $\mathrm{O}$ knockdown de HEX 70a na hemolinfa (e talvez no corpo gorduroso) provocado pela injeção do anticorpo específico foi suficiente para afetar a formação da cutícula, mesmo na presença de outra arilforina, HEX 70b, também presente no corpo gorduroso de adultas faratas (ver Fig. 4). Isto indica que HEX 70a tem participação essencial na formação da cutícula. 


\section{Hexamerinas e a dieta alimentar}

Os genes codificadores de hexamerinas são regulados nutricionalmente no corpo gorduroso de operárias adultas. Mesmo o gene hex 70b, com expressão basal nas operárias adultas, pode ser re-induzido pela dieta. Dieta alimentar rica em pólen, a principal fonte de proteínas para as abelhas, induz o acúmulo de transcritos destes genes (Bitondi et al., 2006; Cunha et al., 2005; Martins et al., 2008).

As operárias nutridoras que alimentam as larvas, tanto de operárias quanto de rainhas, produzem geleia real em suas glândulas hipofaríngeas a partir do alimento que consomem (Ricciardeli D’Albore e Battaglini Bernardini, 1978; Biondi et al., 2003). Enquanto exercem a função de nutridoras, as operárias consomem pólen (Winston, 1991). Assim, alterando a quantidade de pólen oferecido às colmeias foi possível influenciar o consumo e, por extensão, o status nutricional das larvas, e assim, verificar o efeito sobre a expressão gênica. Verificamos que a abundância dos mRNAs de genes que codificam proteínas de estocagem, como hexamerinas e lipoforina, foi alterada nas larvas, dependendo da dieta oferecida à colônia. A manipulação da dieta não alterou somente a expressão destes genes, uma vez que em abelhas A. mellifera adultas, a alteração na alimentação gera uma cascata de eventos metabólicos capaz de influenciar a expressão dos genes da via de insulina, e os títulos de ecdisteróides e do hormônio juvenil (Edgar, 2006). Sabe-se que o alimento ingerido pelas larvas é ainda capaz de gerar uma série de sinais específicos para o crescimento de tecidos periféricos e produção de peptídeos de insulina (ILPs) pelas células neurossecretoras (Rulifson et al. 2002; Ikeya et al. 2002; Broughton et al. 2005). Os ILPs ativam o sistemaalvo da rapamicina (IIS-TOR), promovendo o crescimento (Zhang et al. 2000; Oldham et al. 2000; Oldham e Hafen 2003). Quando comparamos as colmeias que receberam dieta contendo 5 ou $20 \%$ de pólen encontramos níveis mais baixos de mRNA para o gene de insulina (ilp2) naquelas alimentadas com baixo teor de pólen, mas não observamos alteração na expressão de TOR e Chico (insulin receptor substrate - IRS). No entanto, a dieta contendo $20 \%$ de pólen foi capaz de induzir a expressão dos genes codificadores de receptores de ecdisteróides, EcRa e o EcRb, mas não de Usp. A elevada concentração de pólen no alimento também elevou os níveis de mRNA dos genes codificadores de produtos das vias de síntese (mfe2) e degradação (jhe e jheh) do HJ.

Sabe-se desde longa data que larvas de A. mellifera até os 3 dias de vida são bipotentes e podem se desenvolver em operárias ou rainhas dependendo da qualidade e quantidade de alimento recebido das operárias nutridoras. Larvas destinadas a serem operárias recebem geleia real acrescida de pólen e mel, enquanto que larvas de rainhas recebem somente geleia real (Winston, 1991). Para verificar o efeito da dieta larval sobre os níveis de expressão dos 
genes de hexamerinas durante o período de determinação de castas, transferimos larvas de $1^{\circ}$ instar (L1) para alvéolos de operárias e cúpulas de rainhas onde foram mantidas por 4 dias, ou 2 dias, quando trocamos as larvas que estavam nas cúpulas de rainha para os alvéolos de operárias e vice-versa.

Análises por RT-PCR semi-quantitativa e western blot do corpo gorduroso destas larvas revelaram que apenas o gene hex $70 a$ teve sua expressão modulada diferentemente dependendo do tipo de dieta oferecida às larvas. Corpo gorduroso de larvas mantidas exclusivamente com dieta de rainhas durante 4 dias apresentou baixos níveis de mRNA quando comparado àquele extraído de larvas mantidas exclusivamente com dieta de operária durante 4 dias. Nível intermediário de transcritos foi verificado em larvas mantidas 2 dias em cada dieta. Portanto, a expressão do gene hex 70a é sensível à dieta alimentar que determina as castas, mas isto não foi verificado para os outros genes de hexamerinas.

É difícil explicar porque hex 70b, hex 70c e hex 110 não responderam à variação da dieta alimentar. É possível que estendendo-se o período do experimento se consiga obter uma resposta mais clara.

O resultado obtido para hex 70a (maior expressão em larvas de operárias que de rainhas) é semelhante ao obtido de larvas de operárias de $5^{\circ}$ instar (L5F), as quais também têm níveis de transcritos de hex 70a significantemente mais elevados que larvas de rainhas no mesmo estágio (Martins et al., 2010). Este resultado leva-nos a especular se, como foi proposto para a espécie de cupim Reticulitermes flavipes (Zhou et al., 2006a; Zhou et al., 2006b; Zhou et al., 2007; Scharf et al., 2007), maiores níveis de hexamerinas em operárias teriam como consequência a diminuição dos títulos de HJ, ao contrário do que aconteceria nas rainhas. Estudos são necessários para investigar esta hipótese.

\section{Caracterização da hexamerinas}

As hexamerinas são proteínas com massa molecular estimada ao redor de $500 \mathrm{kDa}$ e compostas por seis subunidades em geral com cerca de 70 a $85 \mathrm{kDa}$. Mas algumas hexamerinas podem apresentar maior massa, por exemplo, HEX 110 de A. mellifera e HEX 102 e HEX 109 de Nasonia (Martins et al., 2010), além de uma molécula homóloga de Drosophila, FBP1 (fat body protein 1) (Burmester et al., 1999), têm massa molecular maior que $100 \mathrm{kDa}$. A estrutura hexamérica vem em geral sendo inferida por meio de PAGE não desnaturante e desnaturante (Telfer e Kunkel, 1991). Mas muitos fatores contribuem para alterar a mobilidade eletroforética das proteínas e, consequentemente, tornar imprecisa a determinação da massa molecular (Ryan et al., 1985). Dessa forma a massa molecular inferida da sequência de DNA pode diferir daquela estimada por SDS-PAGE (Willott et al., 
1989). Em busca de melhor definição dos resultados, outras metodologias podem ser adotadas, como a ultra-centrifugação analítica (Ryu et al., 2009) e o crosslinking (Shapiro et al., 1992; Koopmanschap et al., 1992).

Recentemente, Kayser et al. (2009) identificaram uma hexamerina de C. vinula com massa de aproximadamente $500 \mathrm{kDa}$, determinada por diversos métodos, composta de 6 subunidades diferentes de aproximadamente $85 \mathrm{kDa}$. Também foram observados oligômeros com metade da massa molecular de $500 \mathrm{kDa}$, provavelmente trímeros formados pela dissociação do hexâmero nativo. Dessa forma, o complexo hexamérico pode ser um dímero de trímeros. Markl et al. (1992) chegaram à mesma conclusão ao analisar arilforinas de moscas varejeiras.

Análises por cromatografia de filtração em gel associadas a eletroforese em gel de poliacrilamida, espectrometria de massa e western blot mostram que, em A. mellifera, os hexâmeros apresentam massa molecular ao redor de $660 \mathrm{kDa}$, mas foram eluídos na mesma fração, não sendo possível separá-los por este tipo de cromatografia. Resultados obtidos por cromatografia de troca-iônica sugerem que os oligômeros sejam heterogêneos, já que duas hexamerinas, a HEX 70b e a HEX 70c foram eluídas na mesma fração.

Iniciamos a produção in vitro destas hexamerinas, com o intuito de tê-las separadas e puras para esclarecer quais as possíveis combinações na formação de um hexâmero por meio de ensaios por calorimetria. Bactérias foram transformadas para a produção destas proteínas. Ensaios de indução estão em andamento.

Ao mesmo tempo, e utilizando um procedimento relativamente simples, verificamos se as hexamerinas da hemolinfa se associam a extratos de membranas do corpo gorduroso. Hexamerinas sintetizadas durante o estágio de alimentação larval e estocadas na hemolinfa, são seqüestradas pelo corpo gorduroso pré-pupal, pupal e adulto-farato (Ismail e DuttaGupta, 1990; Haunerland, 1996; Burmester e Scheller, 1999). A seletividade do processo de sequestro das hexamerinas requer a presença de um receptor na membrana das células do corpo gorduroso. Surpreendentemente, os receptores de hexamerinas não pertencem a nenhuma classe de receptores conhecida, mas são semelhantes aos seus próprios ligantes, as hexamerinas (Burmester e Scheller, 1996).

Embora tenha havido esforços para caracterizar bioquimicamente estes receptores em C. cephalonica, C. viccina, D. melanogaster, H. zea, Sarcophaga peregrina (Ueno e Natori, 1984; Burmester e Scheller, 1995a; Chung et al., 1995; Burmester et al., 1999; Damara et al., 2010), nenhum domínio típico transmembrana foi encontrado nas sequências destas proteínas (Burmester e Scheller, 1995b). Há evidências de que os receptores de hexamerinas têm entre 80 e $130 \mathrm{kDa}$ e sua fosforilação é mediada por uma tirosina quinase em presença de 20- 
hidroxiecdisona (20E) (Ueno e Natori, 1984; Wang e Haunerland, 1994a e b; Chung et al., 1995; Burmester e Scheller, 1997; Kirankumar et al., 1997; Burmester e Scheller, 1999; Arif et al., 2003).

Análises in silico das sequências de aminoácidos das subunidades de hexamerinas de A. mellifera revelaram sítios de fosforilação por tirosina quinase. Por meio de western blot verificamos a presença de três (HEX 110, HEX 70b e HEX 70c) das quatro hexamerinas em concentrados de membranas do corpo gorduroso.

Os testes para verificar se proteínas da hemolinfa se ligam a proteínas de enriquecidos de membranas mostraram que HEX 110 só interage com a HEX 110; HEX 70a interage com a HEX 70b e HEX 70c; HEX 70b se liga a HEX 70b e HEX 70c.

Este resultado mostra interação entre as subunidades nas membranas celulares, mas não esclarece sobre qual possível receptor.

Estudo recente sugere que o receptor de hexamerinas é uma proteína ancorada à face externa da membrana plasmática por meio de ligação covalente com o glicolipídeo glicosil fosfatidil inositol (GPI) (Budatha et al., 2011). Proteínas ancoradas a GPI apresentam funções variadas (ativação celular, transdução de sinal, hidrólise de proteínas da matriz extracelular, adesão celular) e podem funcionar como receptores e mediar o sequestro de ligantes por meio de fosforilação. A ligação dos receptores ancorados a GPI promove um aumento da concentração local das hexamerinas o que otimiza o sequestro ou endocitose (Abrami et al., 2003; Nohe et al., 2006). 


\section{Conclusão}

Nossos estudos revelaram que as hexamerinas de A. mellifera são mais do que simples proteínas de estocagem ou reservas de aminoácidos. A variação da abundância das hexamerinas no corpo gorduroso e na hemolinfa, durante e após a muda metamórfica, é consistente com a dinâmica temporal de estocagem na hemolinfa durante o estágio larval para reciclagem no corpo gorduroso e utilização durante o estágio pupal. A localização das quatro hexamerinas (HEX 70a, HEX 70b, HEX 70c e HEX 110) no citoplasma de células do corpo gorduroso reforça esta função canônica. HEX 70b, HEX 70c e HEX 110 foram também localizadas em enriquecidos de extratos de membranas do corpo gorduroso podendo estar associadas ao processo de endocitose. Surpreendente foi verificar que as quatro hexamerinas se localizam nos núcleos das células do corpo gorduroso e, além disto, duas delas (HEX 70a e HEX 110) se localizam no citoplasma e núcleo de células germinativas e somáticas dos ovários e testículos. A localização nuclear supõe função reguladora ou estrutural, ainda não descrita. A co-localização de HEX 70a e um marcador de fase S do ciclo celular (EdU) nos núcleos de células ovarianas sugere que HEX 70a tem função na proliferação celular para o desenvolvimento e maturação das gônadas. A inativação in vivo de HEX 70a por meio de injeção de anticorpo específico prejudicou o crescimento dos ovaríolos, reforçando a hipótese de função na proliferação celular, além de impedir a perfeita formação e esclerotização da cutícula, e sinalizar para a antecipação da ecdise.

Experimentos in vivo mostraram que a expressão dos genes de hexamerinas é regulada pela dieta alimentar e pelo título de HJ. Análises in silico identificaram sítio de ligação à proteína Usp (receptor de HJ) na região 5'UTR de cada gene de hexamerina, reforçando a evidência de que o HJ regula a expressão dos genes de hexamerinas.

$\mathrm{Na}$ tentiva de purificar as quatro hexamerinas foram realizadas cromatografias de filtração e troca iônica. Estes procedimentos estão em andamento, mas há indícios do caráter heterogêneo dos hexâmeros, formados por diferentes subunidades de hexamerinas. Em paralelo, iniciamos os procedimentos de expressão in vitro das quatro hexamerinas em bactérias, com o objetivo de obtê-las puras para caracterização da estrutura e de interações entre as subunidades e com outras moléculas. 
Referências Bibliográficas 


\section{Referências Bibliográficas}

Abrami L, Fivaz M, Glauser P-E, Sugimoto N, Zurzolo C, van der Goot FG (2003) Sensitivity of polarized epithelial cells to the pore-forming toxin aerolysin. Infect Immun 71: 739-746.

Adams J, Rothman ED, Kerr WE, Paulino Simões ZL (1977) Estimation of number of sex alleles and queen matings from diploid male frequencies in a population of Apis mellifera. Genetics 86: 583-596.

Andersen SO (2005) Cuticular sclerotization and tanning. In: Gilbert LI, Iatrou K, Gill SS (Eds). Comprehensive Molecular Insect Science, vol 4. Oxford: Elsevier Pergamon Press, pp. 145-170.

Arif A, Scheller K, Dutta-Gupta A (2003) Tyrosine kinase mediated phosphorylation of the hexamerin receptor in the rice moth Corcyra cephalonica by ecdysteroids. Insect Biochem Mol Biol 33: 921-928.

Barchuk AR, Cristino AS, Kucharski R, Costa LF, Simões ZLP, Maleszka R (2007) Molecular determinants of caste differentiation in the highly eusocial honeybee Apis mellifera. BMC Dev Biol 7: 70.

Bateman A, Coin L, Durbin R, Finn RD, Hollich V, Griffiths-Jones S, Khanna A, Marshall M, Moxon S, Sonnhammer EL, Studholme DJ, Yeasts C, Eddy SR (2004) The Pfam protein families database. Nucleic Acid Res 32: D138-141.

Begna D, Han B, Feng M, Fang Y, Li J (2012) Differential expressions of nuclear proteomes between honeybee (Apis mellifera L.) queen and worker larvae: a deep insight into caste pathway decisions. J Proteome Res 11: 1317-1329.

Beintema JJ, Stam WT, Hazes B, Smidt MP (1994) Evolution of arthropod hemocyanins and insect storage proteins (hexamerins). Mol Biol Evol 11: 493-503. 
Biondi C, Bedini G, Felicioli A (2003) Gelatina reale: metodologia proposta per la determinazione dell' origine geografica e della qualità. Apitalia 526: 32-37.

Bishop GH (1920) Fertilization in the honeybee. I. The male sexual organs: their histological structures and physiological functioning. J Exp Zool 31: 225-265.

Bishop GH (1922) Cell metabolism in the insect fat body. I. Cytological changes accompanying growth and histolysis of the fat body of Apis mellifica. J Morphol 36: 567601.

Bishop GH (1923) Cell metabolism in the insect fat body. II. A functional interpretation of the changes in structure in the fat body cells of the honey bee. J Morphol 37: 533-553.

Bitondi MM, Nascimento AM, Cunha AD, Guidugli KR, Nunes FM, Simões ZL (2006) Characterization and expression of the Hex 110 gene encoding a glutamine-rich hexamerin in the honey bee, Apis mellifera. Arch Insect Biochem Physiol 63: 57-72.

Bitondi MMG, Simões ZLP (1996) The relationship between level of pollen in the diet, vitellogenin, and juvenile hormone titers in Africanized Apis mellifera workers. J Apic Res 35: 27-36.

Blackburn MB, Loeb MJ, Clark E, Jaffe H (2004) Stimulation of midgut stem cell proliferation by Manduca sexta a-arylphorin. Arch Insect Biochem Physiol 55: 26-32.

Blom N, Gammeltoft S, Brunak S (1999) Sequence and structure-based prediction of eukaryotic protein phosphorylation sites. J Mol Biol 294: 1351-1362.

Blum H, Beier H, Gross HJ (1987) Improved silver staining of plant proteins, RNA and DNA in polyacrylamide gels. Electrophoresis. 8: 93-99.

Bogolyubov D (2007) Localization of RNA transcription sites in insect oocytes using microinjections of 5-bromouridine 5'-triphosphate. Folia Histochem Cytobiol 45: 129-134. 
Bradford MM (1976) A rapid and sensitive method for the quantification of microgram quantities of protein utilizing the principle of protein-dye binding. Anal Biochem 72: 248-254.

Braun RP, Wyatt GR (1996) Sequence of the hexameric juvenile hormone-binding protein from the hemolymph of Locusta migratoria. J Biol Chem 271: 31756-31762.

Broughton SJ, Piper MDW, Ikeya T, Bass TM, Jacobson J, Driege Y, Martinez P, Hafen E, Withers DJ, Leevers SJ (2005) Longer lifespan, altered metabolism, and stress resistance in Drosophila from ablation of cells making insulin-like ligands. Proc Natl Acad Sci USA 102: 3105-3110.

Budatha M, Ningshen TJ, Dutta-Gupta A (2011) Is hexamerin receptor a GPIanchored protein in Achaea janata (Lepidoptera: Noctuidae)? J Biosci 36: 545-553.

Büning J (1994) The Insect Ovary. Ultrastructure, previtellogenic growth and evolution. London: Chapman \& Hall.

Burmester T (1999) Identification, molecular cloning, and phylogenetic analysis of a nonrespiratory pseudo-hemocyanin of Homarus americanus. J Biol Chem 274: 13217-13222.

Burmester T (2001) Molecular evolution of the arthropod hemocyanin superfamily. Mol Biol Evol 18: 184-195.

Burmester T (2002) Origin and evolution of arthropod hemocyanins and related proteins. J Comp Physiol 172: 95-107.

Burmester T, Antoniewski C, Lepesant JA (1999) Ecdysone-regulation of synthesis and processing of fat body protein 1, the larval serum protein receptor of Drosophila melanogaster. Eur J Biochem 262: 49-55.

Burmester T, Scheller K (1992) Identification of binding proteins involved in the stagespecific uptake of arylphorin by the fat body cells of Calliphora vicina. Insect Biochem Mol Biol 22: 211-220. 
Burmester T, Scheller K (1995a) Ecdysterone-mediated uptake of arylphorin by larval fat bodies of Calliphora vicina: involvement and developmental regulation of arylphorinbinding proteins. Insect Biochem Mol Biol 25: 799-806.

Burmester T, Scheller K (1995b) Complete cDNA-sequence of the receptor responsible for arylphorin uptake by the larval fat body of the blowfly, Calliphora vicina. Insect Biochem Mol Biol 25: 981-989.

Burmester T, Scheller K (1996) Common origin of arthropod tyrosinase, arthropod hemocyanin, insect hexamerin, and dipteran arylphorin receptor. J Mol Evol 42: 713-728.

Burmester T, Scheller K (1997) Developmentally controlled cleavage of the Calliphora arylphorin receptor and posttranslational regulation by 20 -hydroxyecdysone. Eur J Biochem 247: 695-702.

Burmester T, Scheller K (1999) Ligands and receptors: common theme in insect storage protein transport. Naturwissenschaften 86: 468-474.

Burns KA, Gutzwiller LM, Tomoyasu Y, Gebelein B (2012) Oenocyte development in the red flour beetle Tribolium castaneum. Dev Gene Evol 222: 77-88.

Callier V, Nijhout HF (2011) Control of body size by oxygen supply reveals sizedependent and size-independent mechanisms of molting and metamorphosis. Proc Natl Acad Sci USA 108: 14664-14669.

Capurro ML, Moreira-Ferro CK, Marinotti O, James AA, de Bianchi AG (2000) Expression patterns of the larval and adult hexamerin genes of Musca domestica. Insect Mol Biol 9: 169-177.

Cermenati G, Corti P, Caccia S, Giordana B, Casartelli M (2007) A morphological and functional characterization of Bombyx mori larval midgut cells in culture. Invert Suv J 4: 119126.

Chan QWT, Howes CG, Foster LJ (2006) Quantitative comparison of caste differences in honeybee hemolymph. Mol Cell Proteomics 5: 2252-2262. 
Chung SO, Kubo T, Natori S (1995) Molecular cloning and sequencing of arylphorinbinding protein in protein granules of Sarcophaga fat body. J Biol Chem 270: 4624-4631.

Crailsheim K (1986) Dependence of protein metabolism on age and season in the honeybee (Apis mellifera carnica Pollm). J Insect Physiol 32: 629-634.

Crailsheim K, Schneider LHW, Hrassnigg N, Buhlmann G, Brosch U, Gmeinbauer R, Schoffmann B (1992) Pollen consumption and utilization in worker honey bees (Apis mellifera carnica): dependence on individual age and function. J Insect Physiol 38: 409-419.

Cristino AS, Nunes FMF, Lobo CH, Bitondi MMG, Simões ZLP, Da Fontoura Costa L, Lattorff HMG, Moritz RFA, Evans JD, Hartfelder K (2006) Caste development and reproduction: a genome-wide analysis of hallmarks of insect eusociality. Insect Mol Biol 15: 703-714.

Cruz-Landim C (2009) Aparelho reprodutor feminino e ovogênese. In: Abelhas Morfologia e Função de Sistemas. São Paulo: Editora Unesp, pp 15-57.

Cunha AD, Nascimento AM, Guidugli KR, Simões ZL, Bitondi MM (2005) Molecular cloning and expression of a hexamerin cDNA from the honey bee, Apis mellifera. $\mathrm{J}$ Insect Physiol 51: 1135-1147.

Damara M, Gullipalli D, Dutta-Gupta A (2010) Cloning and expression of fat body hexamerin receptor and its identification in other hexamerin sequestering tissue of rice moth, Corcyra cephalonica. J Insect Physiol 56: 1071-1077.

Danty E, Arnold G, Burmester T, Huet JC, Huet D, Pernollet JC, Masson C (1998) Identification and developmental profiles of hexamerins in antenna and hemolymph of the honeybee, Apis mellifera. Insect Biochem Mol Biol 28: 387-397.

Davidowitz G, D'Amico LJ, Nijhout HF (2003) Critical weight in the development of insect body size. Evol Dev 5: 188-197. 
Edgar BA (2006) How flies get their size: genetics meets physiology. Nat Rev Genet 7: 907-916.

Enderle U, Kauser G, Reum K, Scheller K, Koolman J (1983) In: Scheller K (Eds). The larval serum proteins of insects. Stuttgart: Thieme-Stratton, pp. 40-49.

Engels W (1968) Extraoocytäre Komponenten des Eiwachstums bei Apis mellifica. I. Trophocytäre RNS-Zufuhr. Insect Soc 15: 271-288.

Engels W, Kaatz H, Zillikens A, Simões ZLP, Trube A, Braun R, Dittrich F (1990) Honeybee reproduction: vitellogenin and caste-specific regulation of fertility. In: Hoshi M, Yamashita O (Eds). Advanced Invertebrates Reproduction. Elsevier, Oxford.

Estoup A, Solignac M, Cornuet JM (1994) Precise assessment of the number of pratilines and of genetic relatedness in honeybee colonies. Proc R Soc Lond B 258: 1-7.

Faria FS, Garcia ES, Goldenberg S (1994) Synthesis of a hemolymph hexamerin by the fat body and testis of Rhodnius prolixus. Insect Biochem Mol Biol 24: 59-67.

Fleig R, Gutzeit HO, Engels W (1991) Structural organization of ovarian follicle cells in the cotton bug (Dysdercus intermedius) and the honey bee (Apis mellifera). Cell Tissue Res 265: $297-305$.

Gilbert LI, Rybczynski R, Warren JT (2002) Control and biochemical nature of the ecdysteroidogenic pathway. Ann Rev Entomol 47: 883-916.

Gutzeit HO, Zissler D, Fleig R (1993) Oogenesis in the honeybee Apis mellifera: cytological observations on the formation and differentiation of previtellogenic ovarian follicles. Roux's Arch Dev Biol 202: 181-191.

Hagner-Holler S, Pick C, Girgenrath S, Marden JH, Burmester T (2007) Diversity of stonefly hexamerins and implication for the evolution of insect storage proteins. Insect Biochem Mol Biol 37: 1064-1074. 
Hahn DA, Wheeler DE (2003) Presence of a single abundant storage hexamerin in both larvae and adults of the grasshopper, Schistocerca americana. J Insect Physiol 49: 11891197.

Hartfelder K, Engels W (1998) Social insect polymorphism: Hormonal regulation of plasticity in development and reproduction in the honeybee. Curr Topics Dev Biol 40: 45-77.

Haunerland NH (1996) Insect storage proteins: gene families and receptors. Insect Biochem Mol Biol 26: 755-765.

Haydak MH (1970) Honey bee nutrition. Annu Rev Entomol 15: 143-156.

Hiruma K, Riddiford LM (1988) Granular phenoloxidase involved in cuticular melanization in the tobacco hornworm: regulation of its synthesis in the epidermis by juvenile hormone. Dev Biol 130: 87-97.

Hoage TR, Kessel RG (1968) An electron microscope study of the process of differentiation during spermatogenesis in the drone honey bee (Apis mellifera L.), with special reference to centriole replication and elimination. J Ultrastruct Res 24: 6-32.

Hopkins TL, Kramer KJ (1992) Insect cuticle sclerotization. Annu Rev Entomol 37: 273-302.

Hoshizaki DK (2005) Fat cell development. In: Kerkut GA, Gilbert LI (Eds). Comprehensive insect physiology, biochemistry and pharmacology, Oxford: Elsevier, pp 315345.

Hrassnigg N, Crailsheim K (1998) The influence of brood on the pollen consumption of worker bees (Apis mellifera L.). J Insect Physiol 44: 393-404.

Ikeya T, Galic M, Belawat P, Nairz K, Hafen E (2002) Nutrient-dependent expression of insulin-like peptides from neuroendocrine cells in the CNS contributes to growth regulation in Drosophila. Curr Biol 12: 1293-1300. 
Ismail SM, Dutta-Gupta A (1990) 20-hydroxyecdysone mediated activation of larval haemolymph protein uptake by fat body cells of Corcyra cephalonica (Insecta). Biochem Int 22: $261-268$.

Jia K, Chen D, Riddle DL (2004) The TOR pathway interacts with the insulin signaling pathway to regulate C. elegans larval development, metabolism and life span. Development 131: 3897-3906.

Jones G, Jones D, Teal P, Sapa A, Wozniak M (2006) The retinoid-X receptor ortholog, ultraspiracle, binds with nanomolar affinity to an endogenous morphogenetic ligand. FEBS J 273: 4983-4996.

Johnston ML, Wheeler DE (2007) The role of storage proteins in colony-founding in termites. Insect Soc 54: 383-387.

Kamakura M (2011) Royalactin induces queen differentiation in honeybees. Nature 473: $478-483$.

Kayser H (1985) Pigments. In: Kerkut GA, Gilbert LI (Eds). Comprehensive Insect Physiology, Biochemistry and Pharmacology. New York: Pergamon Press, pp 367-415.

Kayser H, Mann K, Machaidze G, Nimtz M, Ringler P, Müller SA, Aebi U (2009) Isolation, characterization and molecular imaging of a high-molecular-weight insect biliprotein, a member of the hexameric arylphorin protein family. J Mol Biol 389: 74-89.

Kerr WE, Silveira ZV (1974) A note on the formation of honeybee spermatozoa. J Apic Res 13: 121-126.

Kirankumar N, Ismail SM, Dutta-Gupta A (1997) Uptake of storage protein in the rice moth Cocyra cephalonica: identification of storage protein binding proteins in the fat body cell. Insect Biochem Mol Biol 27: 671-679.

Kocher SD, Richard FJ, Tarpy DR, Grozinger CM (2008) Genomic analysis of postmating changes in the honey bee queen. BMC Genomics 9: 232. 
Koopmanschap B, Lammers H, de Kort S (1992) Storage proteins are present in the hemolymph from larvae and adults of the Colorado potato beetle. Arch Insect Biochem Physiol 20: 119-133.

Laemmli UK (1970) Cleavage of structural proteins during assembly of the head of bacteriophage T4. Nature 227: 680-682.

Levenbook L, Bauer AC (1984) The fate of the larval storage protein calliphorin during adult development of Calliphora vicina. Insect Biochem 14: 77-86.

Lin H, Yue L, Spradling AC (1994) The Drosophila fusome, a germline-specific organelle, contains membrane skeletal proteins and functions in cyst formation. Development 120: 947-956.

Liu JL, Buszczak M, Gall JG (2006) Nuclear bodies in the Drosophila germinal vesicle. Chromosome Res 14: 465-475.

Locke M, Collins JV (1965) The structure and formation of protein granules in the fat body of an insect. J Cell Biol 26: 857-884.

Locke M, Collins JV (1966) Sequestration of protein by the fat body of an insect. Nature 210: 552-553.

Locke M, Collins JV (1967) Protein uptake in multi vesicular bodies in the moltintermolt cycle of an insect. Science 158: 467-469.

Locke M, Collins JV (1968) Protein uptake into multivesicular bodies and storage granules in the fat body of an insect. J Cell Biol 36: 153-183.

Loeb MJ, Hakim RS (1996) Insect midgut epithelium in vitro: an insect stem cell system. J Insect Physiol 42: 1103-1111.

Loeb MJ (2010) Factors affecting proliferation and differentiation of Lepidopteran midgut stem cells. Arch Insect Biochem Physiol 74: 1-16. 
Lourenço AP, Mackert A, Cristino AS, Simões ZLP (2008) Validation of references genes for gene expression studies in the honey bee, Apis mellifera, by quantitative real-time RT-PCR. Apidologie 39: 372-385.

Louveaux J (1977) Anatomie de l'abeille: XL'appareil reproducteur du male, Bull. Tech Apic 4: 43-48. In: Tozetto SO, Bitondi MMG, Dallacqua RP, Simões ZLP (2007) Protein profiles of testes, seminal vesicles and accessory glands of honey bee pupae and their relation to the ecdysteroid titer. Apidologie 38: 1-11.

Magee J, Kraynack N, Massey HCJr, Telfer WH (1994) Properties and significance of a riboflavin-binding hexamerin in the hemolymph of Hyalophora cecropia. Arch Insect Biochem Physiol 25: 137-157.

Markl J, Burmester T, Decker H, Savel-Niemann A, Harris JR, Süling M, Naumann U, Scheller K (1992). Quaternary and subunit structure of Calliphora arylphorin as deduced from electron microscopy, electrophoresis, and sequence similarities with arthropod hemocyanin. J Comp Physiol B 162: 665-680.

Martins JR (2008) Caracterização da região codificadora e análise de expressão de Hexamerinas durante o desenvolvimento de Apis mellifera. Dissertação (Mestrado em Ciências Biológicas com ênfase em Genética) Faculdade de Medicina de Ribeirão Preto, Universidade de São Paulo.

Martins JR, Nunes FMF, Cristino AS, Simões ZLP, Bitondi MMG (2010) The four hexamerin genes in the honey bee: structure, molecular evolution and function deduced from expression patterns in queens, workers and drones. BMC Mol Biol 11: 23.

Martins JR, Nunes FMF, Simoes ZLP, Bitondi MMG (2008) A honeybee storage protein gene, hex 70a, expressed in developing gonads and nutritionally regulated in adult fat body. J Insect Physiol 54: 867-877.

Martinez T, Wheeler DE (1993) Identification of two storage hexamers in the ant, Camponotus festinatus: accumulation in adult queen-less workers. Insect Biochem Mol Biol 23: $309-317$. 
Martinez T, Wheeler DE (1994) Storage proteins in adult ants (Camponotus festinatus): roles in colony founding by queens and in larval rearing by workers. J Insect Physiol 40: 723-729.

McGraw LA, Gibson G, Clark AG, Wolfner MF (2004) Genes regulated by mating, sperm, or seminal proteins in mated female Drosophila melanogaster. Curr Biol 14: 15091514.

Michelette ERF, Soares AEE (1993) Characterization of preimaginal developmental stages in Africanized honeybee workers (Apis mellifera L.). Apidologie 24: 431-440.

Munn EA, Feinstein A, Greville GD (1967) A major protein constituent of pupal of the blowfly Calliphora erythrocephala. Biochem J 102: 5-6.

Nagamanju P, Hansen IA, Burmester T, Meyer SR, Scheller K, Dutta-Gupta A (2003) Complete sequence, expression and evolution of two members of the hexamerin protein family during the larval development of the rice moth, Cocyra cephalonica. Insect Biochem Mol Biol 33: 73-80.

Neuhoff V, Arold N, Taube D, Ehrhardt W (1988) Improved staining of proteins in polyacrylamide gels including isoelectric focusing gels with clear background at nanogram sensitivity using Coomassie Brilliant Blue G-250 and R-250. Electrophoresis 9: 255-262.

Nijhout HF, Davidowitz G, Roff DA (2006) A quantitative analysis of the mechanism that controls body size in Manduca sexta. J Biol 5: 16.

Noguchi T, Miller KG (2003) A role for actin dynamics in individualization during spermatogenesis in Drosophila melanogaster. Development 130: 1805-1816.

Nohe A, Keating E, Fivaz M, van der Goot FG, Petersen N (2006) Dynamics of GPIanchored proteins on the surface of living cells. Nanomedicine 2: 1-7.

Oldham S, Hafen E (2003) Insulin/IGF and target of rapamycin signaling: a TOR de force in growth control. Trends Cell Biol 13: 79-85. 
Oldham S, Montagne J, Radimerski T, Thomas G, Hafen E (2000) Genetic and biochemical characterization of dTOR, the Drosophila homolog of the target of rapamycin. Genes Dev 14: 2689-2694.

Page RE, Erickson EH (1988) Reproduction by worker honey bees (Apis mellifera L). Behav Ecol Sociobiol 23: 117-126.

Pan ML, Telfer WH (1996) Methionine-rich hexamerin and arylphorin as precursor reservois for reproduction and metamorphosis in female luna moths. Arch Insect Biochem Physiol 33: 149-162.

Pan ML, Telfer WH (1999) Equivalent of riboflavin-binding hexamerin and arylphorin as reserves for adult development in two saturniid moths. Arch Insect Biochem Physiol 42: 138-146.

Patel A, Fondrk MK, Kaftanoglu O, Emore C, Hunt G, Frederick K, Amdam GV (2007) The making of a queen: TOR pathway is a key player in diphenic caste development. PLoS ONE 2: e509.

Patrício K, Cruz-Landim C (2002) Mating influence in the ovary differentiation in adult queens of Apis mellifera L. (Hymenoptera, Apidae). Braz J Biol 62: 641-649.

Perkins DN, Pappin DJ, Creasy DM, Cottrell JS (1999) Probability-based protein identification by searching sequence databases using mass spectrometry data. Electrophoresis 20: $3551-3567$.

Peter MG, Scheller K (1991) Arylphorins and integument. In: Retnakaran A, Binnington K (Eds). The Physiology of Insect Epidermis. North Carolina: Intaka Press, pp 115-124.

Piulachs MD, Guidugli KR, Barchuck AR, Cruz J, Simões ZL, Bellés X (2003) The vitellogenin of the honey bee, Apis mellifera: structural analysis of the cDNA and expression studies. Insect Biochem Mol Biol 33: 459-465. 
Poiani SB, Cruz-Landim C (2012) Storaged products and presence of acid phosphatase in fat body cells at pre-pupal worker stage of Apis mellifera Linnaeus, 1758 (Hymenoptera, Apidae). Micron 43: 475-478.

Rachinsky A, Hartfelder K (1998) In vitro biosynthesis of juvenile hormone in larval honey bees: comparison of six media. In Vitro Cell Dev Biol Anim 34: 646-648.

Rachinsky A, Strambi C, Strambi A, Hartfelder K (1990) Caste and metamorphosis hemolymph titers of juvenile hormone and ecdysteroids in last instar honeybee larvae. Gen Comp Endocr 79: 31-38.

Rembold H (1987) Caste specific modulation of juvenile hormone titers in Apis mellifera. Insect Biochem 17: 1003-1006.

Rembold H, Czoppelt C, Rao PJ (1974) Effect of juvenile hormone treatment on caste differentiation in the honeybee, Apis mellifera. J Insect Physiol 20: 1193-1203.

Rembold H, Kremer JP, Ulrich GM (1980) Characterization of postembryonic developmental stages of the female castes of the honeybee, Apis mellifera L. Apidologie 11: 29-38.

Rhee WJ, Lee EH, Park JH, Lee JE, Park TH (2007) Inhibition of HeLa Cell apoptosis by storage-protein 2. Biotechnol Prog 23: 1441-1446.

Ricciardelli D’Albore G, Battaglini Bernardini M (1978) Origine géographique de la gelée royale. Apidologie 9: 1-17.

Ries H (1932) Die Prozesse der Eibildung und des eiwachstums bei pediculiden und mallophagen. Z Zellforsch Mikrosk Anat 16: 314-388. In: Cruz-Landim C (2009) Aparelho reprodutor feminino e ovogênese. In: Abelhas - Morfologia e Função de Sistemas. São Paulo: Editora Unesp, pp 15-57.

Roberts DB, Turing JD, Loughlin SA (1991) The advantages that accrue to Drosophila melanogaster possessing larval serum protein 1. J Insect Physiol 37: 391-400. 
Rulifson EJ, Kim SK, Nusse R (2002) Ablation of insulin-producing neurons in flies: growth and diabetic phenotypes. Science 296: 1118-1120.

Rutherford K, Parkhill J, Crook J, Horsnell T, Rice P, Rajandream MA, Barrell B (2000) Artemis: sequence visualization and annotation. Bioinformatics 16: 944-945.

Rutz W, Gerig L, Wille H, Lüscher M (1976) The function of juvenile hormone in adult worker honeybees, Apis mellifera. J Insect Physiol 22: 1485-1491.

Ryan R, Anderson D, Grimes W, Law J (1985) Arylphorin from Manduca sexta: carbohydrate structure and immunological studies. Arch Biochem Biophys 243: 115-124.

Ryan RO, Schmidt JO, Law JH (1984) Arylphorin from the hemolymph of the larval honeybee. Insect Biochem 14: 515-520.

Ryu KS, Lee JO, Kwon TH, Choi HH, Park HS, Hwang SK, Lee ZW, Lee KB, Han YH, Choi YS, Jeon YH, Cheong C, Kim S (2009) The presence of monoglucosylated N196glycan is important for the structural stability of storage protein, arylphorin. Biochem $\mathrm{J} 421$ : $87-96$.

Sadrud-Din SY, Loeb MJ, Hakim RS (1996) In vitro differentiation of isolated stem cells from the midgut of Manduca sexta larvae. J Exp Biol 199: 319-325.

Scharf ME, Buckspan CE, Grzymala TL, Zhou X (2007) Regulation of polyphonic caste differentiation in the termite Reticulitermes flavipes by interaction of intrinsic and extrinsic factors. J Exp Biol 210: 4390-4398.

Scheller K, Fisher B, Schenkel H (1990) Molecular properties, functions and developmentally regulated biosynthesis of arylphorin in Calliphora vicina. In: Hagerdorn $\mathrm{HH}$, Hildebrand JG, Kidwell MG, Law JH (Eds). Molecular Insect Science. New York: Plenum Press, pp 155-162.

Schmidt-Capella IC, Hartfelder K (1998) Juvenile hormone effect on DNA synthesis and apoptosis in caste-specific differentiation of the larval honey bee (Apis mellifera L.) ovary. J Insect Physiol 44: 385-391. 
Schmidt-Capella IC, Hartfelder K (2002) Juvenile-hormone-dependent interaction of actin and spectrin is crucial for polymorphic differentiation of the larval honey bee ovary. Cell Tissue Res 307: 265-272.

Shapiro JP, Silhacek DL, Niedz RP (1992) Storage proteins of the larval root weevil Diaprepes abbreviatus (Coleoptera: Curculionidae): riboflavin binding and subunit isolation. Arch Insect Biochem Physiol 20: 315-331.

Silveira ZV (1972) Efeito da temperatura na meiose dos machos de Apis mellifera, II. Ciência e Cultura 24: 160.

Slansky JR, Scriber JM (1985) Food consumption and utilization. In: Kerkut GA, Gilbert LI (Eds). Comprehensive Insect Physiology, Biochemistry and Pharmacology. Oxford Pergamon Press, New York.

Snodgrass RE (1956) Anatomy of honeybee. Comstock Publ Ass Cornell Univ. New York: Press Ithaca, pp 344.

Spradling AC (1993) Developmental genetics of oogenesis. In: Bate M, MartinezArias A (Eds). Drosophila Development. New York: Cold Spring Harbor Press, pp 1-70.

Tanaka ED, Hartfelder K (2004) The initial stages of oogenesis and their relation to differential fertility in the honey bee (Apis mellifera) castes. Arthropod Struct Dev 33: 431442.

Tatar M, Bartke A, Antebi A (2003) The endocrine regulation of aging by insulin-like signals. Science 299: 1346-1350.

Telfer WH, Kunkel JG (1991) The function and evolution of insect storage hexamers. Annu Rev Entomol 36: 205-228.

Tojo S, Betchaku T, Ziccardi V, Wyatt G (1978) Fat body protein granules and storage proteins in the silkmoth, Hyalophora cecropia. J Cell Biol 78: 823-838. 
Tozetto SO (1997) Hormonelle Steuerung in der Entwicklung von Drohnen (Apis mellifera carnica), Dissertation zur Erlangung des Grades eines Doktors der Naturwissenschaften der Fakultät für Biologie der Eberhard-Karls Universität Tübingen. In: Tozetto SO, Bitondi MMG, Dallacqua RP, Simões ZLP (2007) Protein profiles of testes, seminal vesicles and accessory glands of honey bee pupae and their relation to the ecdysteroid titer. Apidologie 38: 1-11.

Tozetto SO, Bitondi MMG, Dallacqua RP, Simões ZLP (2007) Protein profiles of testes, seminal vesicles and accessory glands of honey bee pupae and their relation to the ecdysteroid titer. Apidologie 38: 1-11.

Tysell B, Butterworth FM (1978) Different rate of protein granule formation in the larval fat body of Drosophila melanogaster. J Insect Physiol 24: 201-206.

Ueno K, Natori S (1984) Identification of storage protein receptor and its precursor in the fat body membrane of Sarcophaga peregrina, J Biol Chem 259: 12107-12111.

Velthuis HH (1970) Ovarian development in Apis mellifera worker bees. Entomol Exp Appl 13: 377-394.

Wang Z, Haunerland NH (1991) Ultrastructural study of storage protein granules in fat body of the corn earworm Heliotis zea. J Insect Physiol 37: 353-363.

Wang Z, Haunerland NH (1994a) Receptor-mediated endocytosis of storage proteins by fat body of Helicoverpa zea. Cell Tissue Res 278: 107-115.

Wang Z, Haunerland N (1994b) Storage protein uptake in Helicoverpa zea: arylphorin and VHDL share a single receptor. Arch Insect Biochem Physiol 26: 15-26.

Webb B, Riddiford LM (1988) Synthesis of two storage proteins during larval development of the tobacco hornworm, Manduca sexta. Dev Biol 130: 671-681.

Wheeler DE, Buck NA (1996) A role for storage proteins in autogenous reproduction in Aedes atropalpus. J Insect Physiol 42: 961-966. 
Wheeler DE, Tuchinskaya IL, Buck NA, Tabashnik BE (2000) Hexameric storage proteins during metamorphosis and egg production in the diamond-back moth, Plutella xylostella (Lepidoptera). J Insect Physiol 46: 951-958.

Willot E, Wang XY, Wells M (1989) cDNA and gene sequence of Manduca sexta arylphorin, and aromatic amino acid-rich larval serum protein. J Biol Chem 264: 1905219059.

Wilson MJ, Abbott H, Dearden PK (2011) The evolution of oocyte patterning in insects: multiple cell-signaling pathways are active during honeybee oogenesis and are likely to play a role in axis patterning. Evol Dev 13: 127-137.

Winston ML (1991) The Biology of the honey bee. Harvard University Press, Cambridge, Massachusetts, London, England, pp 4-109.

Wirtz P, Beetsma J (1972) Induction of caste differentiation in the honeybee (Apis mellifera L.) by juvenile hormone. Entomol Exp Appl 15: 517-520.

Wu M, Tischler ME (1995) Utilization of $\left[{ }^{14} \mathrm{C}\right]$ phenylalanine derived from arylphorin or free amino acid in Manduca sexta pharate adults. Arch Insect Biochem Physiol 28: 257272.

Yao TP, Forman BM, Jiang Z, Cherbas L, Chen JD, McKeown M, Cherbas P, Evans RM (1993) Functional ecdysone receptor is the product of EcR and Ultraspiracle genes. Nature 366: 476-479.

Yao TP, Segraves WA, Oro AE, McKeown M, Evans RM (1992) Drosophila ultraspiracle modulates ecdysone receptor function via heterodimer formation. Cell 71: 63-72.

Zakharkin SO, Headley VV, Kumar NK, Buck NA, Wheeler DE, Benes H (2001) Female-specific expression of a hexamerin gene in larvae of an autogenous mosquito. Eur $\mathrm{J}$ Biochem 268: 5713-5722. 
Zalewska M, Kochman A, Estève JP, Lopez F, Chaoui K, Susini C, Ozyhar A, Kochman M (2009) Juvenile hormone binding protein traffic - interaction with ATP synthase and lipid transfer proteins. Biochim Biophys Acta 1788: 1695-1705.

Zhang H, Stallock JP, Ng JC, Reinhard C, Neufeld TP (2000) Regulation of cellular growth by the Drosophila target of rapamycin dTOR. Genes \& Dev 14: 2712-2724.

Zhou XG, Oi FM, Scharf ME (2006a) Social exploitation of hexamerin: RNAi reveals a major caste-regulatory factor in termites. Proc Natl Acad Sci USA 103: 4499-4504.

Zhou X, Tarver MR, Bennett GW, Oi FM, Scharf ME (2006b) Two hexamerin genes from the termite Reticulitermes flavipes, sequence, expression, and proposed functions in caste regulation. Gene 376: 47-58.

Zhou X, Tarver MR, Scharf ME (2007) Hexamerin-based regulation of juvenile hormone dependent gene expression underlies phenotypic plasticity in a social insect. Development 134: 601-610. 
Apêndice 


\section{Apêndice}

\section{Trabalhos em colaboração}

- Lourenço AP, Martins JR, Bitondi MMG, Simões ZLP (2009) Trade-off between immune stimulation and expression of storage protein genes. Arch Insect Biochem Physiol, DOI: $10.1002 /$ arch.20301.

- Lourenço AP, Martins JR, Guidugli-Lazzarini KR, Macedo LF, Bitondi MMG, Simões ZLP (2012) Costs of bacterial infection on storage protein gene expression and reproduction in queenless Apis mellifera worker bees on distinct dietary regimes. J Insect Physiol, 58: 1217-1225. 
Figura 29: Genes de hexamerinas. (A) Diagrama esquemático da estrutura dos genes de hexamerinas. Éxons e íntrons estão representados por retângulos e linhas, respectivamente. As setas à direita e à esquerda de cada gene indicam os códons de início e término, respectivamente. As UTRs sequenciadas estão marcadas em cinza escuro. Número dos nucleotídeos (nt) estão indicados para os éxons e os íntrons. (B) Sequências codificadoras completas (determinadas por sequenciamento). Éxons estão separados por asteriscos. Os primers utilizados para o sequenciamento dos genes estão sublinhados. O sequenciamento dos genes foi realizado por: Cunha et al. (2005) para hex 70b; Martins et al., (2008) para hex 70a; Martins (2008) e Martins et al. (2010) para hex $110 \mathrm{e}$ hex $70 c$. 


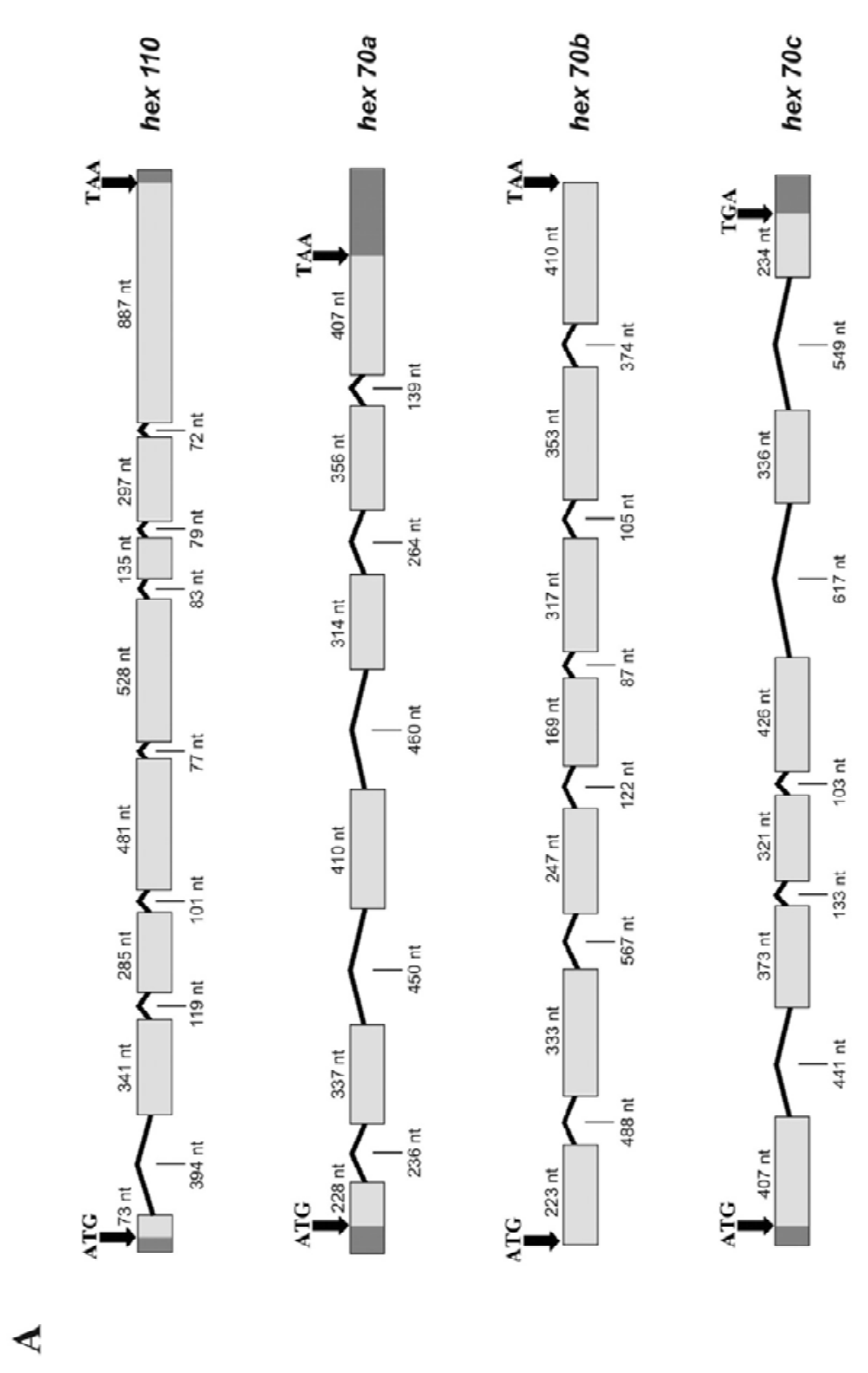

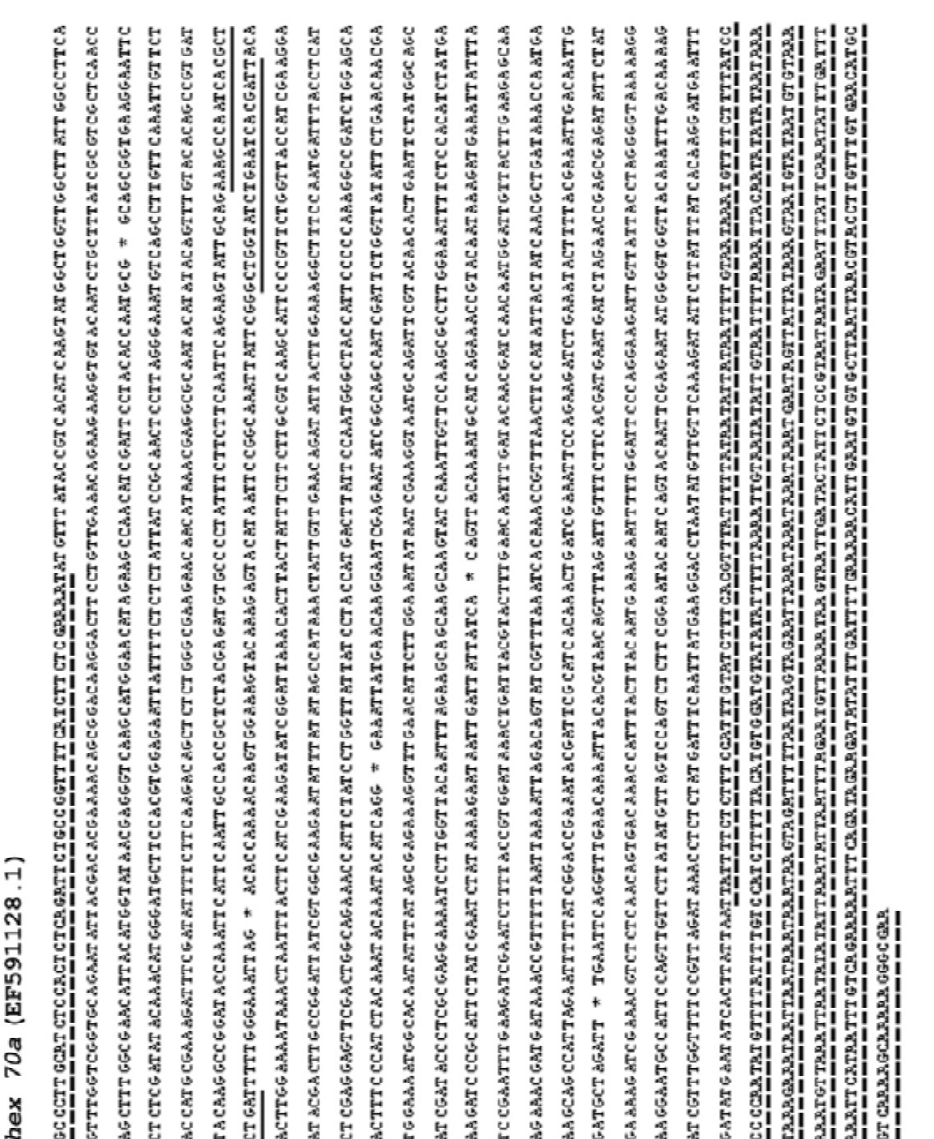
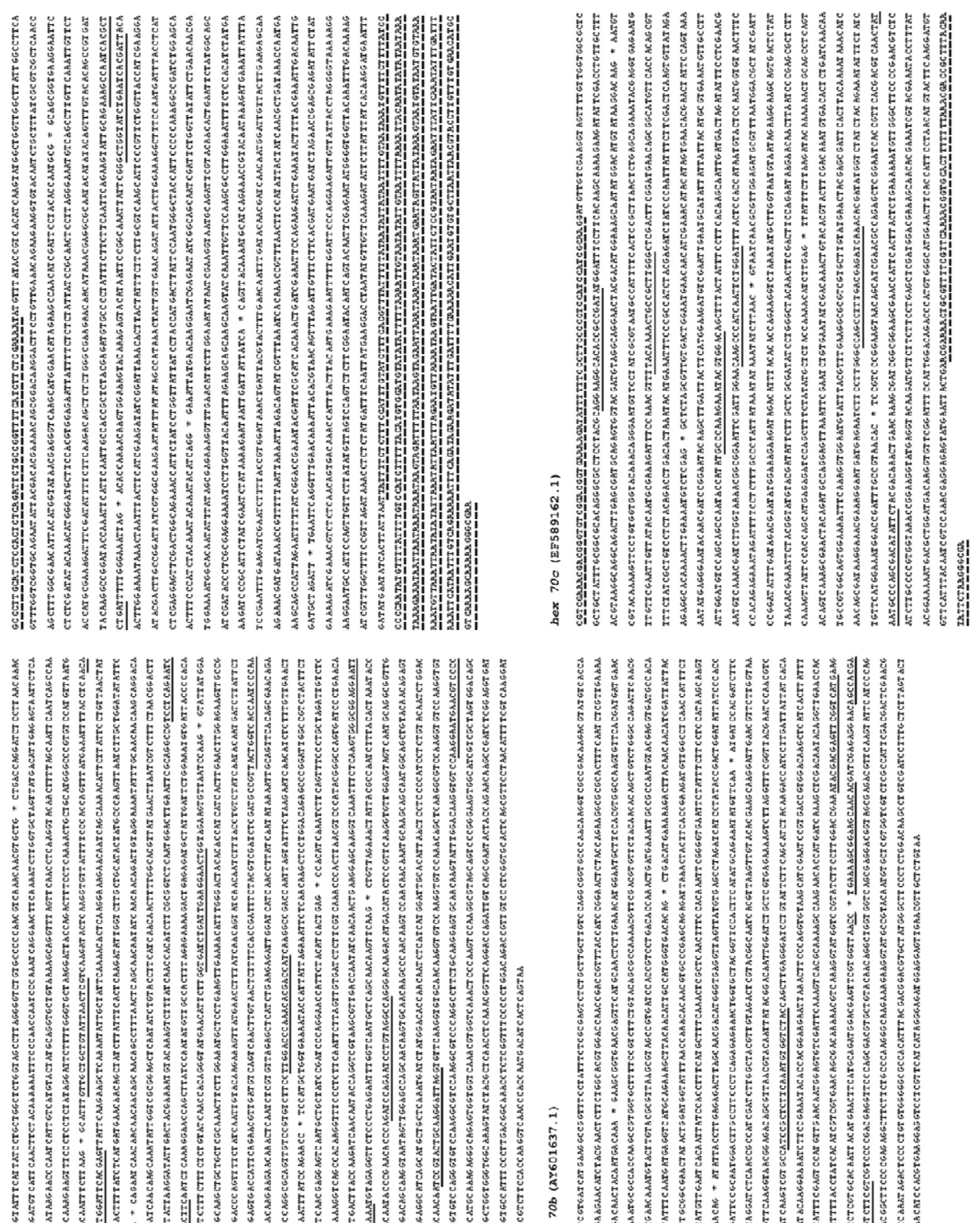

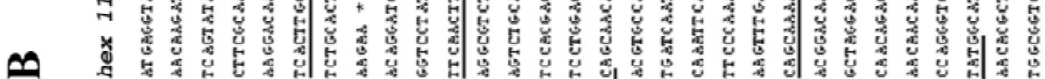

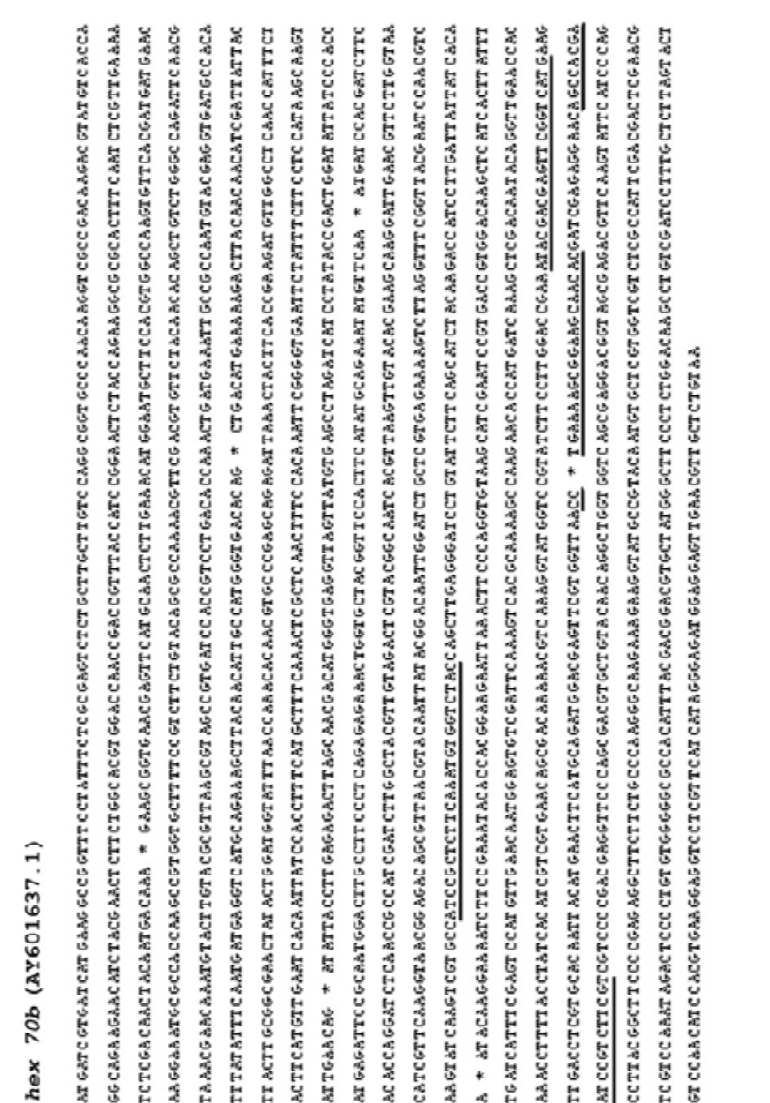


Figura 30: Expressão dos genes de hexamerinas no corpo gorduroso de operárias, rainhas e zangões em desenvolvimento e adultos. (A) A abundância de transcritos de hex 110, hex 70a, hex 70b e hex 70c foi caracterzada por RT-PCR semi-quantitativa seguida por eletroforese em gel de agarose corado com brometo de etídio. O gene codificador de actina de A. mellifera foi utilizada como controle interno e normalizador . (B) Diagrama simplificado baseado na abundância dos transcritos detectados por RT-PCR. As linhas espessas, finas e tracejadas no diagrama representam alto, intermediário e baixo nível de transcritos, respectivamente. L5F e L5S: fase de alimentação e tecelagem do casulo do $5^{\circ}$ instar larval. PP: pupa farata. Pw, Pp, Pdp, Pb, Pbl, Pbm e Pbd: fases sucessivas do estágio pupal de operárias e rainhas. P1 a P13: fases sucessivas do estágio pupal de zangões. RE: recém emergida. Ov: rainha ovipositora. Números indicam a idade em dias do adulto. 


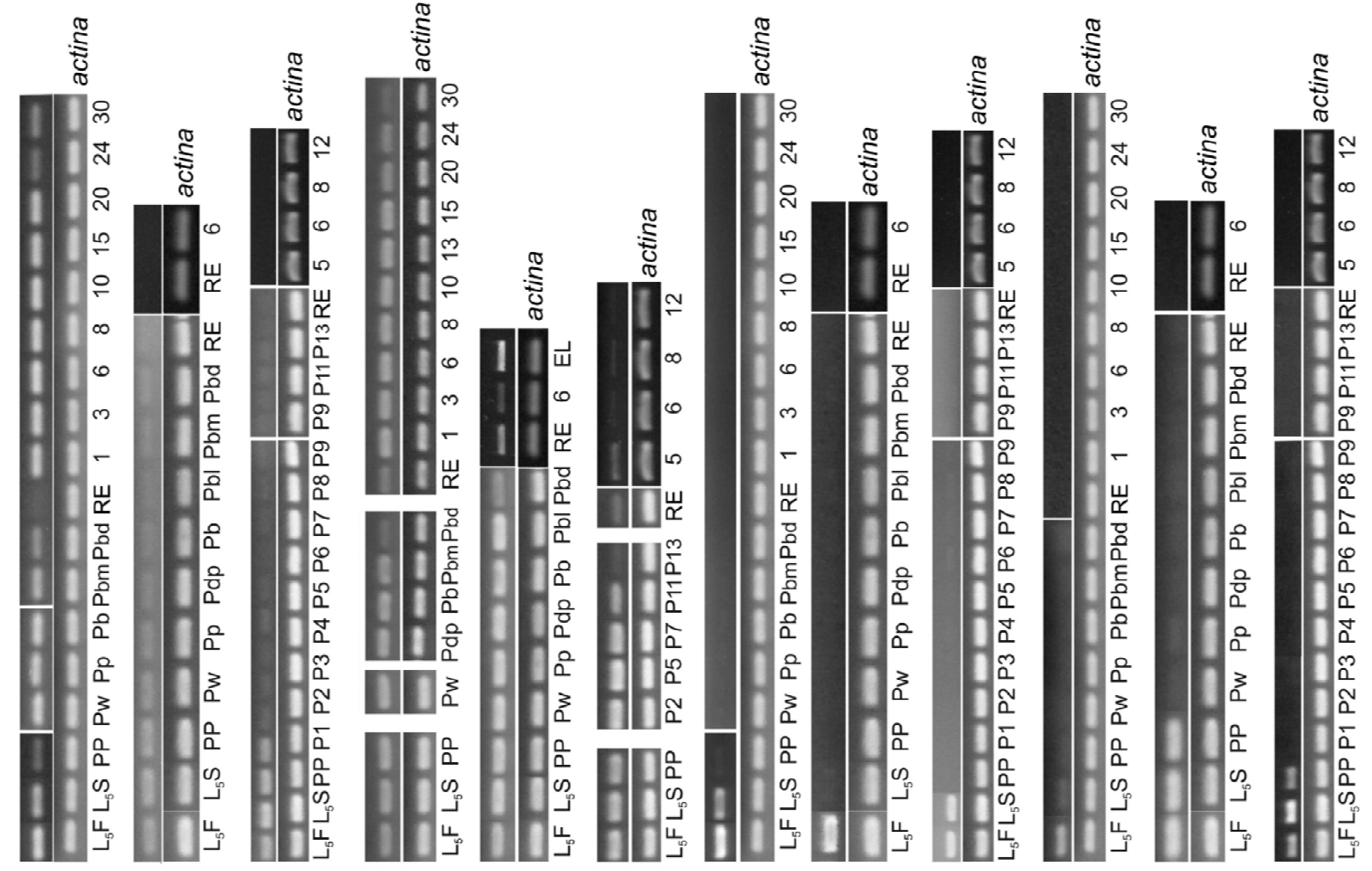

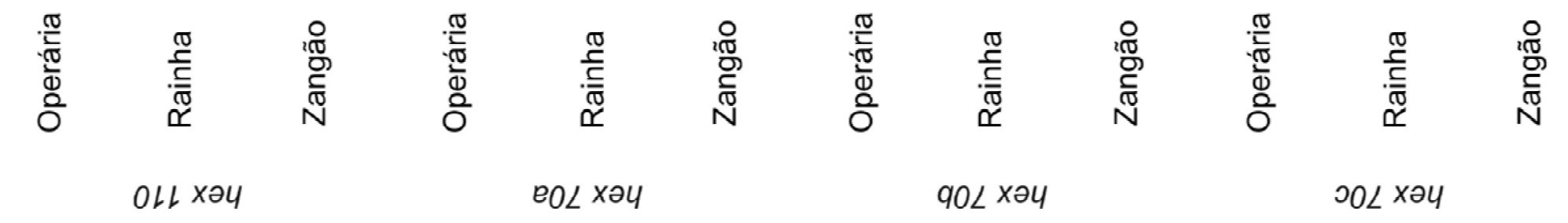

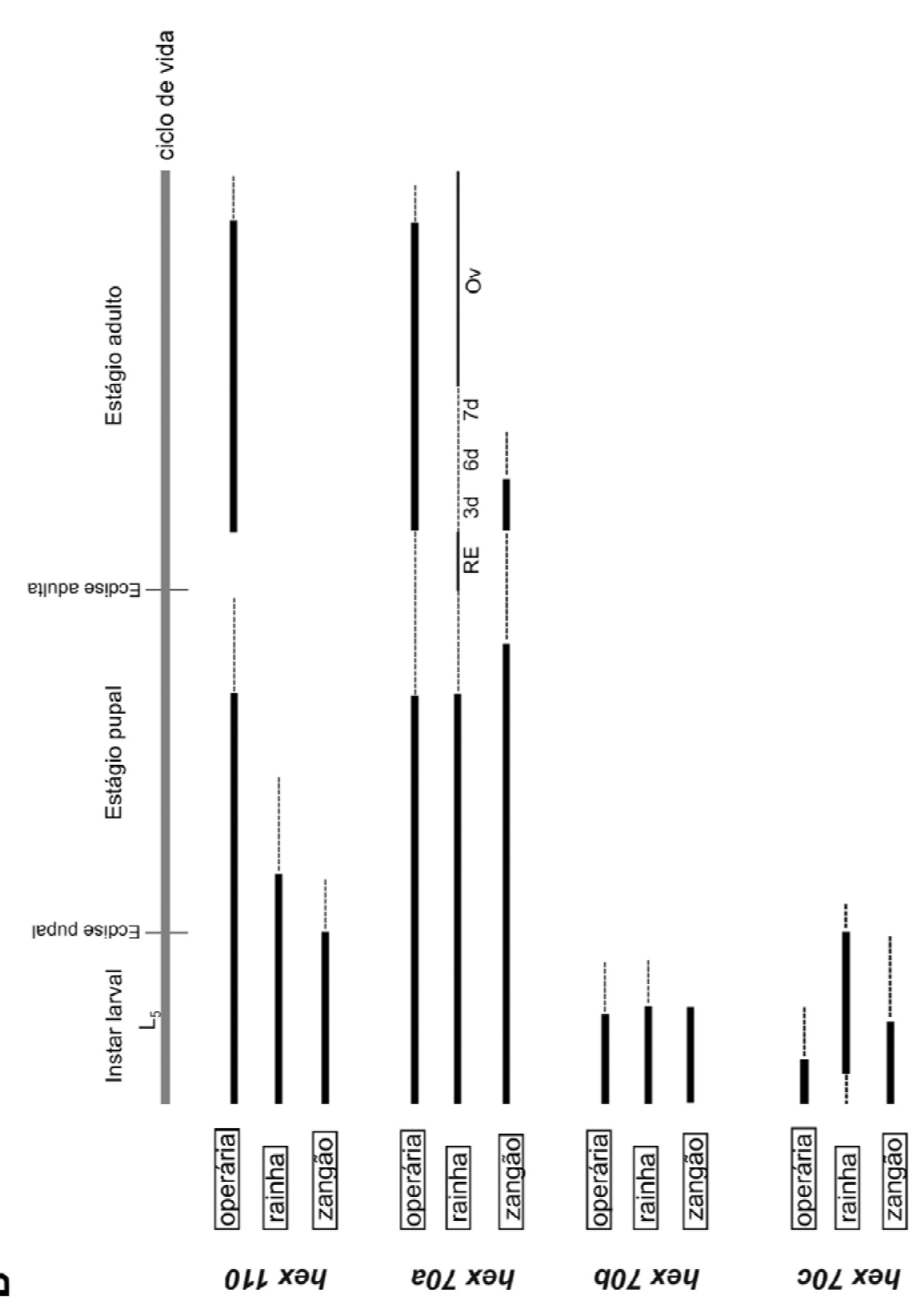


Figura 31: Expressão dos genes de hexamerinas nas gônadas de operárias, rainhas e zangões em desenvolvimento e adultos. (A) A abundância de transcritos de hex 110, hex 70a, hex 70b e hex 70c foi detectada por RT-PCR semi-quantitativa seguida por eletroforese em gel de agarose corado com brometo de etídio. O gene codificador de actina de A. mellifera foi utilizado como controle interno e normalizador. (B) Diagrama simplificado baseado na abundância dos transcritos detectados por RT-PCR. As linhas pretas, cinza-escuro, cinza-claro e tracejadas no diagrama representam diferentes níveis de transcritos (alto, intermediário, baixo e muito baixo, respectivamente). Dados não mostrados são indicados (////). L4 e L5: $4^{\circ}$ e $5^{\circ}$ instar larval. L5F e L5S: fase de alimentação e tecelagem do casulo do $5^{\circ}$ instar larval. PP: pupa farata. Pw, Pp, Pdp, Pb, Pbl, Pbm e Pbd: fases sucessivas do estágio pupal de operárias e rainhas. P1 a P13: fases sucessivas do estágio pupal de zangões. RE: adultos recém-emergidos. Ov: rainha ovipositora. Números indicam a idade em dias do adulto. 


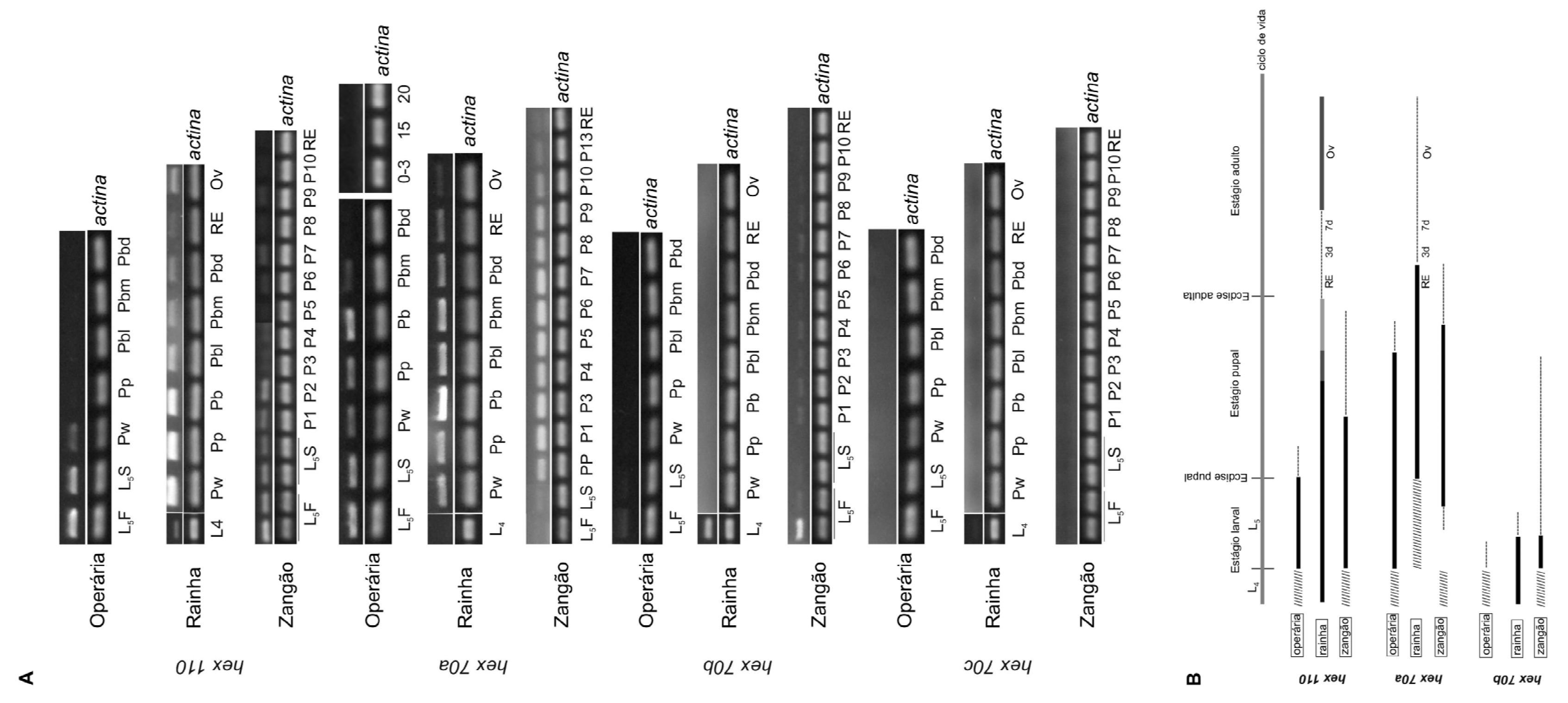




\section{Mutiplos alinhamentos incluindo HEX 70a, HEX 70b, HEX 70c e HEX 110}

HEX70a MFIPSHQVWLVGLLAFS-LVGAEYYDTKTADKDFLLKQKKVYNLLYRVAQPALANITWYN HEX70b MIV---IMKAGF LF LASLCLLVQAVPNKVADKTYVTRQKNIYELFWHVDQPTVYHPELYQ HEX70C MLSK--VVLLVALAAICGAQGASYAGRHTADMDFLHKQKKIFDLLLYVRQADLSDAEWYD HEX110 M-----RYF I ILLALVALGVCAPNVKQRAADQDLLNKQQDVIQLLQKISQP-IPNQELQN

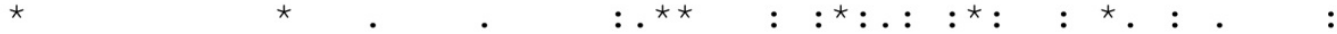

HEX70a EGQAWNIEANIDSYTNAAAVKEFLSIYKHGMLP-RGELFSLYYPQLLREMSALFKLFYHA HEX70b KARTFNLVENLDNYNDKEAVNEFMQLLKHGMLP-RGQVFTMMNKEMRHQAVVLFRLLYSA HEX70C VGRNYDMESNMDMYKDKNVVQKFLWWYKQGMF LSRNAIFTPLNSEQKYEVRMLFELLYNA HEX110 LGASYDIESNSHQYKNPI IVMYYAGAVKAGLVQPQGTTFSNS ISQLRKEVSLLYRILLGA

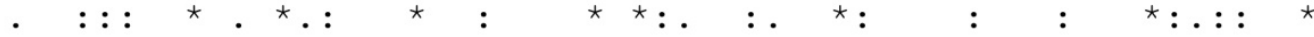

HEX70a KDFDIFFKTALWAKNNINEAQYIYSLYTAVITRPDTKFIQLPPLYEMCPYFFFNSEVLQK HEX70b KTFDVFYNTAVWARFNVNEQMYLYALSVAVIHRPDTKLMKLPPMYEVMPHLYFNDEVMQK HEX70C KDFQTFYKTAAWARLRMNSGMFTTAFSIAVLYRPDTKYMKFPAIYEIYPNYFFDSSVIEE HEX110 KDYQTFLKTAAWARVHVNEGQFLKAFVAAVLTRQDTQGVIFPPVYEILPQHHLDSRVIQE

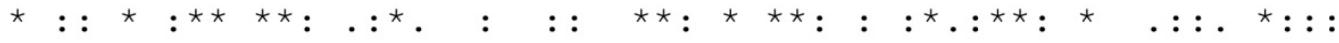

HEX70a ANHALIFGKLDTKTSG-KYKEYIIPANYSGWYLNHDYNLENKLIYFIEDIGLNTYYFFLR HEX70b AYNIAMGDTADMKKTYNNIDYYLLAANYTGWYLTKHNVPEQRLNYETEDVGLNHFYFMLN HEX70C AQNLKMSRGSSVVTGMNNIETYIVNTNYSSKNMREYNDPEYKLDYFMEDVELNAYYYYMR HEX110 AQNIAIQN----TQGKNNQQNILIPVNYS----ALLSHDEQQLSYFTQDIGLAAYYAQVN

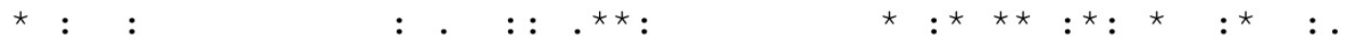

HEX70a QAFPFWLPSKEYDLP---------------------------DYRGEEYLYSHKLLLN HEX 70b HNYPPFMLSNSLNFP-----------------------------QIRGEFYFFLHKQVLN HEX70C EMLPYWMSSSQYHMPK----------------------------EIRGQLYYFLHKQLMT HEX110 LAGYIQEQNQQQQQQQPLTQQQYQQQ IVGKYLQQQAGQQDQQANIGRGAQYLYLHQQLLA

$$
\text { ... . } \star \star \star \star ~: *:: \text { : }
$$

HEX70a RYYLERLSNDLPHLEEFDWQKPFYPGYYPTMTYSNGLPFPQRPIWSNFPIYKYKYIREIM HEX70b RYYLERLSNDMGEVSYVSLDHPIPTGYYPTMRFRNGLAFPQRETGATVPLHMQKYVQMIH HEX70C RYFLERMSNDLGKTAEFDWNKPINSGFYSTIMYSNGVTFPQRNRFSSLPYYKYKYLNVIN HEX110 RYELNRLSNGLGP IKDIDYEN-VQSLYQPHLRGLNGLEFAGRPQNLQLQSQRNQLIQYVA

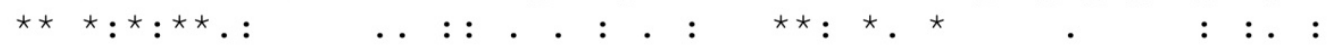

HEX70a NKESRISAAIDSGYILNNDGKWHNIYSEKGLNILGNIIEGNADSYNTEFYGSIDTLARKI HEX70b DLHTRISTAIDLGYVVDSYGNHVKLYTKQGLNVLGNIVQGNGDSVNVQLYGQLDLLVRKV HEX70C ALEMRLMDAIDSGYLIDEYGKKIDIYTPEGLNMLGNVIEGSSDS INTKFYGMYDILARDI HEX110 TLEKRLRDA IDSGNVITPQGVFLSLYQPQGMNILGDLIEGTGRSVNPRYYGSLQAAARKL

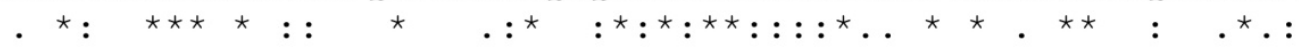

HEX70a LGYNLEAASKYQIVPSALEIFSTSMKDPAFYRIYKRIIDYYHSYKMHQKPYNKDEIIYPN HEX70b LGFGYESNVKYQVVPSALQMWSTSLRDPVFFSIYKTILDYYHKYKENLPKYTTEELNFPG HEX70C LGYNFDFQNKNNLIPSALQSYSTSMRDPAFYMLYQNILSYFLRYKKLQPQYSQSELQMPG HEX110 LGNAPEVENIWDYTPSSLELGEVAVHDPVFYQLYKKVMNLYQQYQQSLPVYQYNDLILPG

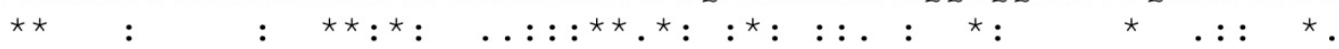

HEX70a LKIESFTVDKLITYFEQFDTTINNGLLLEEQRNDDK--PFLIKIRQYRLNHKPFNFHITI HEX70b VSIESVTVDKLITYFDHFESMLNNGVS IQSHAKAKN---TMIKARQYRLNHKPFTYHIVV HEX70C VKFESVNIDKLYTYFDKCDTLINNAVAVENFKGG-M--YLRLKARRACMNYERFTYKINI HEX110 VTIQNVDVSQLVTLFTDFYVDLDAVTGHQSQQQQEEQTQSRVRAHLKRLDHQPYQYKIAV

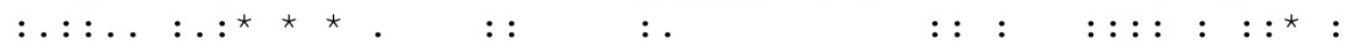


HEX70a NADKPMK-AAIRIFIGPKYDSH-HKLIEIPEDLKYFYEIDNWMLDLNSGLNKITRNSLDC HEX70b NSDKNVK-GMVRIFLGPKYDEFGHEVDLVHNYMN-FMQMDEFVVNLKSGSNTIERNSHES HEX70C NSDKETK-GMMRIFLGPAFDEIKHDMVYLQKYFYLFMEMDRFAVTLRPGSNSIERQSSES HEX110 HSEQNVPGAVVRVFLGPKHDHQ-GRP IS I SKNQHLFVELDQF IQNLHAGENT I IRNSQQA $:::$ :
$:{ }^{\star}:{ }^{\star}{ }^{\star} \quad .{ }^{\star}$
: :
$\star::{ }^{\star}$.
$\star \ldots \star \star \star \star \star * *:$

HEX70a FFTMNDLEPSEIFYEKIETSLNSDKPFTYNE--RIFGFPGRLLLPRGKKEGMPFQLFLYV HEX70b VFVVPDEVPSDVLYNRLVVSEDGSETFKYSS--QPYGFPERLLLPKGKKEGMPYNVLVVV HEX70C PFTTSTIMPSDIFYDKLNKAIGGSEPFTYSE--KMLGFPERLILPRGKPEGMRYKMFFFL HEX110 PGQSPDWPSTSQIQRGVNAAIRSQEPFYITEPHQIF SFPARLSLPKGQPQGFPLQFLVVI

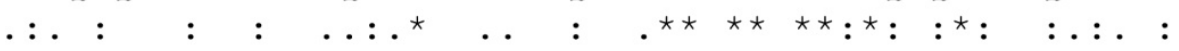

HEX70a SPVS-S-

HEX70b SPFDDS-

HEX70C SSMDES-

HEX110 SSSNPLNVPYGPVIPEQSLTYQDQQYQVVSVDQYQQLKEQGQISQVGGGIQQNVEVLPEN *. .

$\operatorname{HEX} 70 \mathrm{a}$

$\mathrm{HEX} 70 \mathrm{~b}$

$\mathrm{HEX} 70 \mathrm{C}$

HEX110

LVNAQQQVQAVRNYYANLYTKYHGQYPNTQIQNPVGQGQDMTYSVQGVGVVNAGGWLGQQ

$\operatorname{HEX} 70 \mathrm{a}$

HEX 70b

$\operatorname{HEX} 70 \mathrm{c}$

HEX110

GNSWSQQQVQQAQQVQQQMQAAMAAVQQSQQRHQHAAQMIYGHQQSHHGLH INSSPSSVQ

$\operatorname{HEX} 70 \mathrm{a}$

$\mathrm{HEX} 70 \mathrm{~b}$

$\operatorname{HEX} 70 \mathrm{c}$

HEX110

SGQQQQSVLQGLGVQGVQQGVQGVQTAQGVQGVQGVQGVQGVQGVQGVPGLLQGVQQVFG

$\mathrm{HEX} 70 \mathrm{a}$

HEX 70b

$\mathrm{HEX} 70 \mathrm{C}$

HEX110

QGVQGMNVPYGMQRGQSGGQTWSNSQVQGVAVPGSGIVASGQQHAGGWQS IYAQPQTVQD

HEX70a -------EYNQYNSRIWGGYKFDKRSFGFPLDKPLYDFNYEGPNMLFKDILIYHKDEFDM

HEX70b ------NVVQIDSPVWGRHIYDGRAMGFPLDKPVDPLLLVLSNIHVKEVLVHHREMEEL

HEX70C ------NTKSYEIPLYGKMTLDDKVFGFPLDRPMWAWNFT IPNMYFKDVF IYNRPNEES

HEX110 QIVSEYYQNKPISEVIGGAISLDGKPLGFPLDRPLSLGALSVPNIFVKDVLVFHQGQPTN

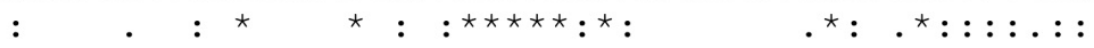

HEX70a NITY

HEX70b NVAL

$\mathrm{HEX} 70 \mathrm{C}$ MNY-

HEX110 DITQ

Figura 32: Múltiplos alinhamentos das sequências deduzidas das hexamerinas HEX 70a, HEX 70b, HEX 70c e HEX 110 de A. mellifera utilizando ClustalW 1.83. 


\title{
The four hexamerin genes in the honey bee: structure, molecular evolution and function deduced from expression patterns in queens, workers and drones
}

\author{
Juliana R Martins', Francis MF Nunes², Alexandre S Cristino³, Zilá LP Simões² and Márcia MG Bitondi²
}

\begin{abstract}
Background: Hexamerins are hemocyanin-derived proteins that have lost the ability to bind copper ions and transport oxygen; instead, they became storage proteins. The current study aimed to broaden our knowledge on the hexamerin genes found in the honey bee genome by exploring their structural characteristics, expression profiles, evolution, and functions in the life cycle of workers, drones and queens.

Results: The hexamerin genes of the honey bee (hex 70a, hex 70b, hex 70c and hex 110) diverge considerably in structure, so that the overall amino acid identity shared among their deduced protein subunits varies from 30 to $42 \%$. Bioinformatics search for motifs in the respective upstream control regions (UCRs) revealed six overrepresented motifs including a potential binding site for Ultraspiracle (Usp), a target of juvenile hormone $(\mathrm{JH})$. The expression of these genes was induced by topical application of $\mathrm{JH}$ on worker larvae. The four genes are highly transcribed by the larval fat body, although with significant differences in transcript levels, but only hex 110 and hex $70 a$ are re-induced in the adult fat body in a caste- and sex-specific fashion, workers showing the highest expression. Transcripts for hex 110, hex 70a and hex70b were detected in developing ovaries and testes, and hex 110 was highly transcribed in the ovaries of egglaying queens. A phylogenetic analysis revealed that HEX 110 is located at the most basal position among the holometabola hexamerins, and like HEX 70a and HEX 70c, it shares potential orthology relationship with hexamerins from other hymenopteran species.

Conclusions: Striking differences were found in the structure and developmental expression of the four hexamerin genes in the honey bee. The presence of a potential binding site for Usp in the respective $5^{\prime}$ UCRs, and the results of experiments on $\mathrm{JH}$ level manipulation in vivo support the hypothesis of regulation by JH. Transcript levels and patterns in the fat body and gonads suggest that, in addition to their primary role in supplying amino acids for metamorphosis, hexamerins serve as storage proteins for gonad development, egg production, and to support foraging activity. A phylogenetic analysis including the four deduced hexamerins and related proteins revealed a complex pattern of evolution, with independent radiation in insect orders.
\end{abstract}

\section{Background}

Hexamerins essentially participate in the dynamics of amino acid storage and exploitation that occurs during insect development. These six-subunit proteins are primarily synthesized by the larval fat body and are massively stored in hemolymph as an amino acid source for

* Correspondence: mmgbit@usp.br

2 Faculdade de Filosofia, Ciências e Letras de Ribeirão Preto, Departamento de Biologia, Universidade de São Paulo, Ribeirão Preto, SP, Brazil Full list of author information is available at the end of the article development toward the adult stage [1]. They also may function as $\mathrm{JH}$-binding proteins [2,3], and in addition, there is circumstantial evidence supporting the hypothesis that larval hexamerins are targeted for egg production [4-8].

While hexamerins have been the focus of numerous studies in solitary insects $[9,10]$, the characterization of these proteins in social insects has received much less attention, in spite of the potential for discovering unique 
physiological functions linked to aspects of the social way of life. Workers of an ant species may use hexamerins as an amino acid source for brood nourishment, and there is circumstantial evidence that, by acting as a JH-binding protein, hexamerins regulate $\mathrm{JH}$ titer and caste differentiation in a termite species [11-15].

The highly eusocial honey bee hatches as a larva after a $72 \mathrm{~h}$ embryonic stage, and develops through a series of molts that define the five larval instars. This is a period of feeding, and the larva gains weight while it is continuously fed by worker bees. During the larval stage, queens, workers and drones have distinct nutritional requirements. Depending on the quality and quantity of nutrition, a diploid female larva develops as a queen or as a worker. A queen-destined larva is fed with secretions produced by worker hypopharyngeal and mandibular glands, the royal jelly, in a much higher proportion than a worker-destined larva. As a supplement to its nutritional regime, the worker larva also receives pollen, nectar and honey. Drone larval nourishment is composed of these same nutrients, but they are fed on a larger quantity of food, and their diet also differs in quality when compared to that given to workers [16]. Female and male larvae grow enormously because of these nutrients, and accumulate proteins, lipids and glycogen for use as structural materials and energy during the subsequent non-feeding pupal and pharate-adult stages. Duration of development from egg to adult eclosion differs considerably among queens, workers and drones, spanning 16, 21 and 24 days, respectively [17] with some differences among $A$. mellifera subspecies.

The single adult queen in the hive is adapted to egg production. When fertilized, the eggs will give rise to workers and occasionally to a new queen, while non-fertilized eggs become drones. The functionally sterile workers perform a series of flexible but age-correlated tasks, a phenomenon known as age polyethism. The younger worker bees usually stay inside the hive and are engaged in brood rearing, queen tending, nest building, nest cleaning, and food processing. Older workers take over the duties of foraging for pollen and nectar that are used to provision and maintain the hive. Drones do not have any known function other than mating with the queen [18].

Our goal was to determine whether these morphotypes (queen, worker, drone), which are so divergent in their developmental rate, size, morphology and other essential characteristics, and which perform very distinct functions as adults in the hive, also show hexamerin gene expression profiles that are correlated with their unique developmental trajectories. The current study was undertaken to deepen our knowledge of the four hexamerin genes found in the honey bee genome [19-21] by exploring their structures, expression patterns, and putative functions using a comparative approach. To this end we determined (1) the features of the full-length cDNA coding sequences and their conceptual translation products; (2) the potential regulatory sequences present in the respective 5' UCRs; (3) the expression patterns in the fat body and gonads of developing and adult queens, workers and drones; (4) the effect of $\mathrm{JH}$ on the expression in larval fat body; (5) the relative quantities of hexamerin transcripts in females and drones during the metamorphic molt and adult stage, and (6) the evolutionary relationships among the honey bee hexamerins and related members of the hemocyanin superfamily in other insect species. Consistent with the hypothesis that hexamerins have multiple functions in the honey bee, our findings disclosed striking structural differences among the hexamerin gene sequences and tissue-, caste- and sex-specific expression patterns. Additionally, the recognition of potential $\mathrm{JH}$-target sites in 5' UCR of all hexamerin genes together with the observed JH-effect on the levels of hexamerin transcripts indicate regulation by this hormone.

\section{Results}

\section{Structural characteristics of the hexamerin CDSs and} respective translation products

The entire CDSs of hex $70 b$ and hex $70 a$, as well as a portion of their respective 5 ' and 3 ' untranslated regions (UTRs), were previously sequenced by our research group [19,21]. Part of the hex 110 CDS (a cDNA fragment of $180 \mathrm{bp}$ ) also was previously cloned and sequenced in our laboratory [20]. In the current work, the sequencing of hex 110 was extended to the entire CDS and part of the 5 ' and 3' UTRs. In addition, we cloned and sequenced the hex 70c CDS as well as segments of its UTRs. Sequence analyses using the Artemis platform [22] allowed comparisons of the structural characteristics of hex CDSs (Figure 1A, Additional files 1, 2, 3 and 4). Each of these sequences is present as a single copy in the Honeybee Genome Assembly (version 4.0) as confirmed by BLAST searches. The hex 70a, hex $70 b$ and hex $70 c$ sequences are tandemly arrayed in GroupUn.53, whereas hex 110 is separately positioned in Group 11.32

The translation products contain the N-terminal sequences determined by Danty et al [23] using automated Edman degradation. The conserved N, M and C hemocyanin domains (Figure 1B) were identified in all hexamerin subunits (HEX 70a, HEX 70b, HEX 70c and HEX 110), but as previously observed [20], the hemocyanin C domain of HEX 110 is interrupted by a 291 amino acid insertion. This insertion is very rich in glutamine and glutamic acid (Glx) and contributes significantly to the total Glx content (20.9\%) of HEX 110.

Some features of the honey bee hexamerin genes and of the respective deduced subunits are compiled in Table 1. The four hexamerin subunits are also characterized by 


\section{A}
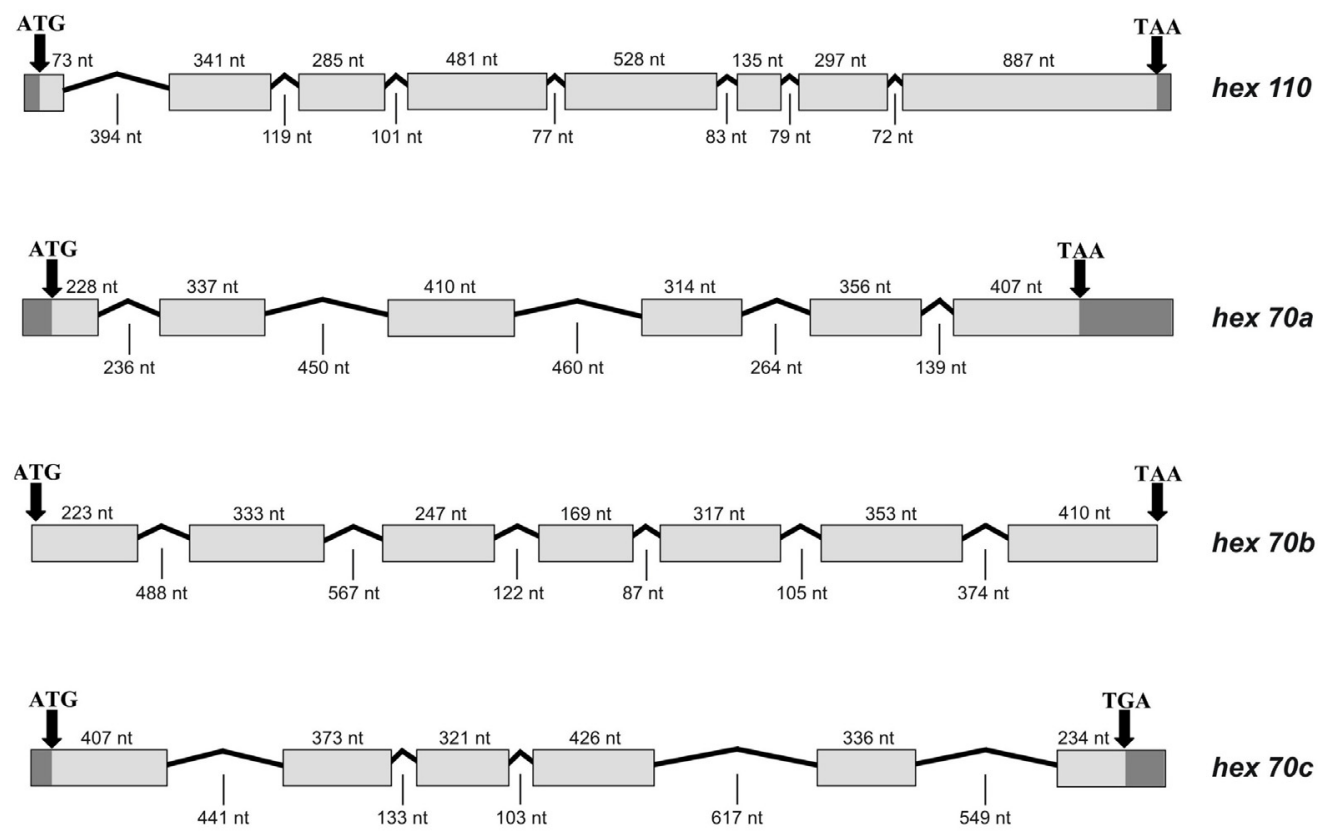

\section{B}
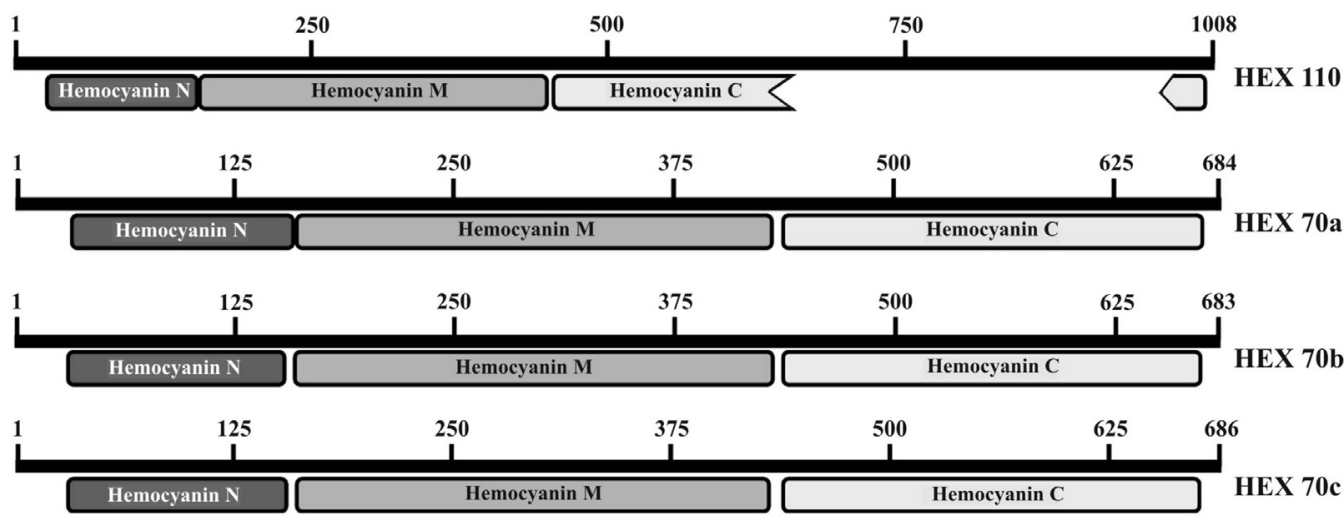

Figure 1 Hexamerin genes and deduced protein subunits. (A) Schematic diagram of hexamerin genes structure. Exons and introns are represented by boxes and lines, respectively. Arrows at the right and left of each gene indicate initiation and termination codons, respectively. Sequenced untranslated regions (UTR) are marked in dark gray. Number of nucleotides (nt) are indicated for exons and introns (exons and the primers used for hexamerin sequencing are marked in the nucleotide sequences shown in Additional files 1, 2, 3 and 4). (B) Diagrams of the deduced hexamerin proteins showing the N, M and C hemocyanin domains. Note that the C domain is interrupted in the HEX 110 sequence. Signal peptides and conserved motifs are marked in hexamerin sequences shown in Additional files 5, 6, 7 and 8.

the presence of glycosylation sites, a conserved histidine and motifs typically found in other insect hexamerins (Additional files 5, 6, 7 and 8). We used the software http://phobius.sbc.su.se for prediction of signal peptides and transmembrane topology from the amino acid sequences of each of the hexamerin subunits in the honey bee, HEX110, HEX70a, HEX 70b and HEX 70c. Hydropathy profiles were produced for each of them and included in the Additional file 9. The subunits are predicted to contain each a signal peptide (Table 1, hydrophobic amino acids specified in Additional file 9) that directs transport of the protein through the secretory pathway. As expected, none of the subunits contain transmembrane helices. With respect to amino acid composition, HEX 70a and HEX 70c contain a relatively high quantity of phenylalanine, tryptophan and tyrosine $(18.2 \%$ and $16.9 \%$, respectively), and thus belong to the class of aromatic amino acid-rich hexamerins (or arylphorins) [24]. 
Table 1: Characteristics of hexamerin genes and respective subunits in the honey bee.

\begin{tabular}{|c|c|c|c|c|c|c|}
\hline \multirow[b]{2}{*}{$\begin{array}{l}\text { Hexamerin } \\
\text { genes/ } \\
\text { subunits }\end{array}$} & \multicolumn{2}{|c|}{ Gene structure } & \multicolumn{4}{|c|}{ Conceptual product } \\
\hline & ORF (nt) & Exon number & $\begin{array}{c}\text { Amino acid } \\
\text { Number }\end{array}$ & $\begin{array}{l}\text { Molecular } \\
\text { mass }(\mathrm{kDa})\end{array}$ & pl & $\begin{array}{l}\text { Signal } \\
\text { peptide } \\
\text { length }\end{array}$ \\
\hline $\begin{array}{c}\text { hex } 70 a / \text { HEX } \\
70 a\end{array}$ & 2,055 & 6 & 684 & 79.19 & 6.45 & 21 \\
\hline $\begin{array}{c}\text { hex 70b/HEX } \\
70 \mathrm{~b}\end{array}$ & 2,052 & 7 & 683 & 77.26 & 6.64 & 21 \\
\hline $\begin{array}{c}\text { hex } 70 \mathrm{c} / \mathrm{HEX} \\
70 \mathrm{c}\end{array}$ & 2,061 & 6 & 686 & 79.44 & 7.67 & 19 \\
\hline $\begin{array}{c}\text { hex } 110 / \mathrm{HEX} \\
110\end{array}$ & 3,027 & 8 & 1008 & 110.21 & 6.37 & 24 \\
\hline
\end{tabular}

Molecular mass and pl calculated using http://expasy.org/cgi-bin/protparam and http://phobius.sbc.su.se/

With their relatively high methionine content, HEX 70b (4.4\%) and HEX 70c (6.4\%) can be included in the class of methionine-rich hexamerins, which are composed of 4 to $11 \%$ methionine [10].

The overall amino acid identity shared among the deduced honey bee hexamerins varies from $30 \%$ to $42 \%$. A multiple alignment using ClustalW 1.83 (Additional file 10) revealed that HEX 70a, HEX 70b and HEX 70c are more similar to each other ( 39 to $42 \%$ identity) than they are to HEX 110 (30 to $32 \%$ identity).

\section{Overrepresented motifs in upstream control regions (UCRs)} Motif analyses of the UCRs were carried out with two goals in mind: to search for potential JH response elements, and to search for hexamerin-specific conserved regions. Table 2 shows six DNA motifs, here named site1 to site6, that are overrepresented in the UCRs of the four hexamerin genes. All of the six motifs were mapped on an extension of the UCR corresponding to $1.5 \mathrm{~kb}$ from the translation start codon (Figure 2A). Site1 is $80 \%$ identical to the D. melanogaster Ultraspiracle (Usp) binding site, also known as chorion factor-1 (CF1, [Flybase ID: FBgn0003964]) [25], and is located very close to the 5' end (Figure 2A and 2D). Two site1 motifs enrich the hex 110 UCR, whereas only one was found in each of the UCRs of the three hex 70 genes. None of the other five motifs (site2 to site6) are similar to any binding site described to date in the TRANSFAC database, and may be specific to hexamerin gene UCRs. The hex $70 b$ UCR showed the greatest complexity because it is the only one containing all six motifs. Few of these motifs were found in the hex $70 a \mathrm{UCR}$, possibly because it is still a gapped DNA region (Figure 2A).

Based on Figure 2A, we graphically represented the types (Figure 2B) and quantities (Figure 2C) of the potential regulatory sites shared by the four honey bee hexam- erin UCRs. Site1 is shared by all four hexamerin genes; site 2 is shared by hex 70a and hex 70b; site 3 is present in hex 70b, hex 70c and hex 110; site4 is specific to the hex 70 genes (it is absent from the hex 110 UCR); and site 5 and site6 were both detected in hex 70b, hex 70c and hex 110 (Figure 2B). Therefore, the hex $70 \mathrm{~b}$ and hex 70c UCRs share a maximum of five of these motifs whereas the hex 70a and hex 110 UCRs share only one motif (Figure $2 \mathrm{C}$ ). This relationship suggests that at least some of the hexamerin genes are co-regulated.

\section{Effect of $\mathrm{JH}$ on the expression of hexamerin genes}

$\mathrm{JH}$-treatment was performed at the feeding phase of the $5^{\text {th }}$ larval instar. During this developmental phase, larvae have a high titer of JH in hemolymph [26]. The treatment with exogenous hormone aimed to maintain $\mathrm{JH}$ titer at a high level for a prolonged period of time, thus circumventing the normal decay that normally occurs at the transition from the feeding to the spinning phase [26]. Figure 3 shows that expression of the genes hex $70 b$ and hex $70 c$ is higher in JH-treated larvae than in the controls, although the JH-effect on the expression of hex $70 a$ and hex 110 is more discrete. Together, these results support a function of $\mathrm{JH}$ in inducing the expression of hexamerin genes in honey bee larvae.

\section{Evolutionary relationship among the honey bee hexamerins and related proteins}

We investigated the evolutionary relationships among 45 hexamerin amino acid sequences from six insect orders (Hymenoptera, Diptera, Lepidoptera, Coleoptera, Isoptera, and Orthoptera), and hemocyanins from 8 insect species and from a crustacean. The tree structure mainly reflects the molecular relationship at the level of insect order (Figure 4). Within the hymenopteran cluster, the honey bee HEX 110 (named AmeHEX 110 in the 
Table 2: DNA motifs discovered in the 5' UCRs of the honey bee hexamerin genes.

\begin{tabular}{|c|c|c|c|c|}
\hline Motif name & Motif & Church & Roc-auc & P-value \\
\hline site1 & GnnGwnnmCsskC & $9.3 \mathrm{E}-09$ & 0.98 & $3.5 \mathrm{E}-06$ \\
\hline site2 & TTGyGngnnrrnAawk & $3.8 \mathrm{E}-06$ & 0.87 & 4.4E-04 \\
\hline site3 & GsnsakwCgmnmG & $3.9 \mathrm{E}-06$ & 0.97 & $2.2 \mathrm{E}-04$ \\
\hline site4 & $\begin{array}{l}\text { gwnAtnnnanwnwTCG } \\
\text { AwAwys }\end{array}$ & $3.8 \mathrm{E}-06$ & 1.00 & $8.0 \mathrm{E}-07$ \\
\hline site5 & $\begin{array}{l}\text { awCGAwAAAwnnknn } \\
\text { wwRnA }\end{array}$ & $9.3 \mathrm{E}-09$ & 1.00 & $2.1 \mathrm{E}-05$ \\
\hline site6 & ATykCGAaTnmrannA & 4.1E-06 & 0.99 & $9.5 \mathrm{E}-06$ \\
\hline
\end{tabular}

Site 1 motif is $80 \%$ similar to the USP binding site of $D$. melanogaster. The other motifs (sites 2 to 6 ) do not have similarity to any binding site sequences in TRANSFAC database, and may be specific of hexamerin genes.

tree) grouped with two hexamerins from Nasonia vitripennis wasps, NviHEX102 and NviHEX109. Like the honey bee HEX 110 (with $110 \mathrm{kDa}$ and $20.9 \% \mathrm{Glx}$ ), these wasp hexamerins have a molecular mass higher than that typically exhibited by hexamerins $(102 \mathrm{kDa}$ and $109 \mathrm{kDa}$, respectively) and are composed of a high or very high proportion of Glx (here defined as $10 \%$ to $15 \%$, and $>15 \%$, respectively). Explicitly, NviHEX102 and NviHEX109 are composed of $14.2 \%$ and $15.1 \%$ Glx, respectively. The other hymenopteran hexamerins [NviHEX79, NviHEX75, NviHEX81, NviHEX94, NviHEX83; CfeHEX2; AmeHEX70a (HEX 70a), AmeHEX70b (HEX 70b), AmeHEX70c (HEX 70c)], which are in the range of 70-95 kDa, generally display an intermediary Glx content $(7 \%<\mathrm{Gl}<<10 \%)$. Exceptions in this group are NviHEX79 and NviHEX81, which have higher amounts of Glx (10.1\% and $11.8 \%$, respectively).

Most of the hymenopteran hexamerins (seven of twelve) contain more than $15 \%$ aromatic amino acids, and are therefore considered arylphorins. Five of twelve meet the criterion for inclusion in the methionine-rich class. A wasp hexamerin (NviHEX79) and two of the honey bee hexamerins (HEX 70a, HEX 70b) contain more than 10\% leucine and are here defined as leucine-rich.

Hexamerins from the coleopterans Tribolium castaneum and Tenebrio molitor form a well-defined group (Figure 4). Without exception, they are all arylphorins. Aside from TcaHEX5, they all have a high Glx content (at 9.8\% Glx, TcaHEX5 fails to meet our criterion for inclusion among the high-Glx hexamerins by a small margin).

Among lepidopterans (Figure 4), the arylphorin BmoSP2 is positioned separately from the methioninerich hexamerins HceHEX1, HzeHEX, TniJHSP2, CfuDAP2, BmoSP1 and HceHEX2, which are organized in two branches, one of them also including HviHEX. As only part of the HviHEX sequence is available in data Bank, we could not classify it as an arylphorin or a methionine-rich hexamerin. All lepidopteran hexamerins contain intermediary or low Glx $(<7 \%)$ content, and only three of them (HceHEX1, HzeHEX and TniJHSP) are rich in leucine. Interestingly, these leucine-rich hexamerins were grouped in a single branch.

A branch of dipteran hexamerins (Figure 4) included the very high Glx (20\%)/high molecular mass DmeFBP1 and two other hexamerins from D. melanogaster, Dme7320 and Dme8100, both containing a high Glx content (13.7\% and $10.8 \%$, respectively), but a typical molecular mass $\sim 70 \mathrm{kDa}$. All hexamerins in this branch are rich in leucine. The other three main branches consist of hexamerins in the range of 82-99 $\mathrm{kDa}$. One of them clustered the DmeLSP1 isoforms $(\alpha, \beta$ and $\gamma)$. The other two branches grouped some Anopheles gambiae hexamerins with OatHEX 1.2 from the mosquito Ochlerotatus atropalpus, and some A. gambiae hexamerins with DmeLSP2. Except for some incomplete sequences (Aga29840, Aga16795, and Aga31208) for which we could not determine the exact amino acid composition, all the hexamerins forming these three branches are arylphorins, and OatHEX1.2, DmeLSP1 $\alpha$ and DmeLSP1 $\beta$ are also rich in methionine. Several of them have a high Glx content. None is rich in leucine.

The only orthopteran hexamerin used in tree construction, LmiJHBS (Figure 4), is distinguished by a high proportion of leucine. The basal position of this hexamerin is evident. Two isopteran hexamerins, RflHEX1 and RflHEX2 clustered in a single branch. Both are arylphorins, but RflHEX1 is also rich in methionine. RflHEX2, but not RflHEX1, has a high Glx content (10.4\%).

As expected, the insect hemocyanins clustered separately from the hexamerins (Figure 4), and formed a wellsupported monophyletic clade (1.0 Bayesian posterior probability), with ScuHC1 at the most basal position.

\section{Expression of hexamerin genes in the fat body of developing and adult workers, queens and drones}

Figure 5 schematically represents RT-PCR transcriptional profiles from the current and previous studies of the four 
(A)

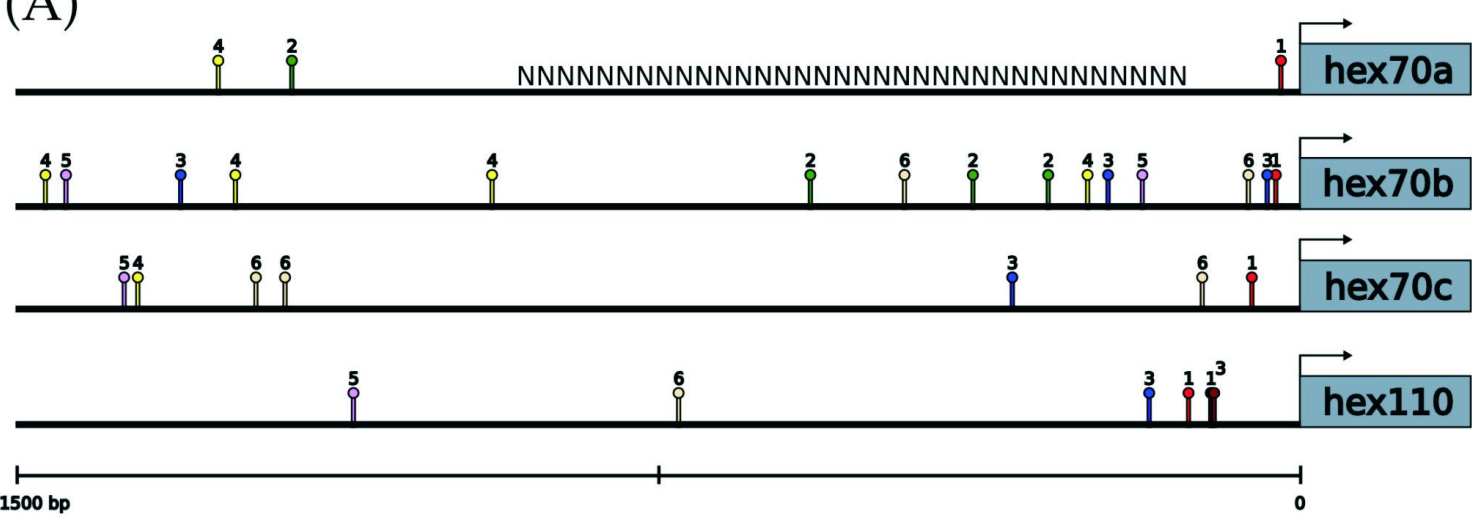

(B)

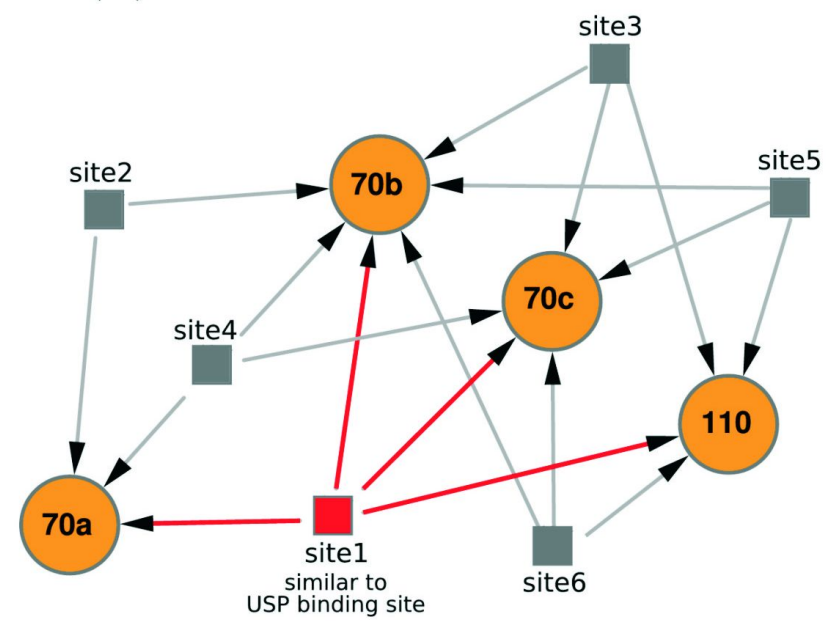

(C)

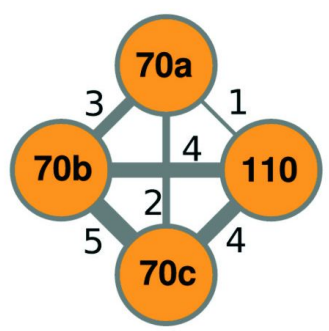

(D)

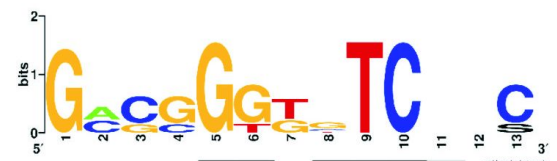

CFI-Usp

hex 110

hex $70 \mathrm{c}$

hex70b

hex70a

Figure 2 Overrepresented motifs in the upstream control regions of the hexamerin genes. (A) Spatial distribution of the six overrepresented DNA motifs in the $1.5 \mathrm{~kb}$-long upstream control regions (UCRs) of the four honey bee hexamerin genes. Motif sequences are specified in Table 2. The $\mathrm{N}$ series in the hex 70a UCR indicates that this DNA region is still undefined in the honey bee genome. (B) Putative co-regulatory network showing the relationship between the six overrepresented motifs and hexamerin genes (orange circles). The site 1 motif (red square) is similar to the Usp binding element (also named CF1) in D. melanogaster. Sites 2 to 6 (grey squares) are not similar to any of the D. melanogaster binding site sequences described in the TRANSFAC database, and may be specific to hexamerin genes; (C) Based on the co-regulatory network, a scheme was constructed using the number of sites shared among hexamerin gene UCRs. The thickness of the bars linking hexamerin genes (orange circles) is directly proportional to the quantity of putative co-regulatory sites (the number of sites is indicated) shared by the four genes. (D) Alignment of the target sites similar to CF1Usp found in the 5' UCR of honey bee hexamerin genes. The graph shows the sequence conservation at each position while the height of symbols indicates the relative frequency of each nucleotide at that position.

hexamerin genes in the fat body of workers, queens and drones (see Additional file 11). Relative expression is shown from the 5 th larval instar throughout the pupal and adult stages. Because the expression data on earlier larval phases (2nd to 4th larval instars) was mostly obtained using workers instead of queens and drones, they are not shown here.

In the fat body of workers, hex 110 transcripts were abundant from the 5th larval instar throughout the pupal stage, with a decrease in the amount of transcripts nearby the time of adult eclosion. But expression increased again in adult workers. In contrast, in the fat body of drones and queens, hex 110 expression was found basically in the 5 th larval instar, extending up to the early pupal stage in queens. The expression of hex $70 a$ differs from hex 110 mainly in adults, which showed sex- and caste-specific patterns of hex $70 a$ transcription. Workers and drones showed high levels of hex $70 a$ transcripts up to the ages of 30 and 5 days, respectively. In 3- to 7-day-old virgin queens, hex $70 a$ expression was reduced in comparison 


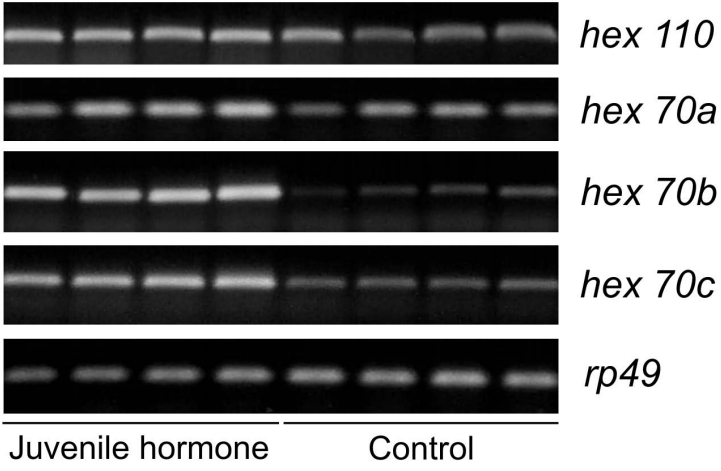

Figure 3 Effect of juvenile hormone on the expression of the four hexamerin genes. The hormone (diluted in acetone) was topically applied on the dorsum of $5^{\text {th }}$ instar larvae (feeding phase, L5F). Controls were treated with acetone only. Gene expression was analyzed $24 \mathrm{~h}$ after treatment. Hexamerin transcript abundance analyzed by RT-PCR followed by electrophoresis of the amplified cDNA on ethidium bromide-stained agarose gels. The A. mellifera rp49 gene was used as a loading control.

to the newly emerged ones, but increased again in older, egg-laying queens. Comparatively, the expression of hex $70 a$ is lower in adult queens than in adult workers. The expression of the other two hexamerin genes, hex $70 \mathrm{~b}$ and hex $70 c$, was detectable only in the 5th larval instar of females and males.

Together, the data summarized in Figure 5 highlight that: (1) all the honey bee hexamerin genes are highly expressed in the larval fat body of workers, queens and drones, and (2) hex 110 and hex $70 a$ were transcribed in a caste- and sex-specific fashion in pupal and adult fat body. These expression patterns suggest that in addition to their primary role as storage proteins that supply amino acids during non-feeding pupal development, hexamerins have different functions in the adult stage.

Using real-time RT-PCR we quantified the levels of the four hexamerin transcripts in the fat body at two periods of the honey bee life cycle: during larval-pupal transition and in adults. Figure 6A shows that the transcriptional profiles are similarly modulated, with an abrupt increase in the quantity of transcripts in the 5th larval instar, followed by a marked decrease in newly ecdysed pupae. However, at definite points of this developmental period, we found interesting differences among the honey bee morphotypes. In workers and drones, the four hexamerin transcripts reached maximal levels during the feeding phase of the 5th larval instar (L5F). In queens, maximal transcript levels were detected at the subsequent spinning phase (L5S) (except for hex $70 b$ transcripts, which reached maximal levels in $\mathrm{L} 5 \mathrm{~F}$ ). Moreover, the maximal expression in workers and drones was significantly higher than the maximal expression in queens (except for hex
$70 \mathrm{c}$ ). Figure $6 \mathrm{~A}$ also shows that in workers and drones at the L5F phase, when expression of the four hexamerin genes reached a maximum, the levels of hex 110/hex $70 \mathrm{~b}$ transcripts were much higher than the levels of hex $70 a$ / hex $70 c$ transcripts.

Pearson's correlation coefficient (R) was used to evaluate the relationship among these expression profiles. Figure $6 \mathrm{~B}$ graphically represents the hexamerin genes (orange circles) linked by bars. The greater the thickness of the bar, the greater the $\mathrm{R}$ value. In queens, the expression profiles of hex 110 and hex 70c were the only positively correlated. In drones, by contrast, the expression profiles of all the hexamerin genes except hex 70b/hex 110 were positively correlated. Similarly, in workers the expression profiles of all but hex 70b/hex 110 and hex 70b/hex 70c were positively correlated. Therefore, workers and drones share similar transcriptional profiles during the larval-pupal transition that are distinct from those exhibited by queens. In other words, workers and drones differ from queens in the patterns of co-expression of the four hexamerin genes.

Fat body from adult females was also used to quantitatively compare the levels of hex $70 a$ and hex 110 transcripts (the only ones found at this stage). We compared age-matched workers and queens (3-day-old), but to investigate the effect of mating in transcript levels, we also included egg-laying queens in this analysis. Figure 7 shows that 3-day old workers have a significantly higher quantity of both transcripts than queens, independent of their reproductive status.

\section{Expression of hexamerin genes in the gonads of developing and adult workers, queens and drones}

The expression of hexamerin genes was also investigated in developing and adult female and male gonads using RT-PCR (Figure 8; see Additional file 12). The only hexamerin gene apparently inactive in ovaries and testes is hex $70 c$, as presumed from the complete absence of its transcript in these organs. The levels of hex $70 \mathrm{~b}$ transcripts were abundant, but only in the larval gonads of queens and drones. A high level of hex 110 mRNA was found in the larval gonads of workers, queens, and drones. Expression then decreases during the pupal stage to be resumed exclusively in the ovaries of egg-laying queens. Similarly, a relatively high level of hex $70 \mathrm{a}$ transcripts was found in the gonads of workers and drones at the larval/pupal stages, and in the ovaries of queens at the pupal/early adult stages. This is followed by transcript depletion in the gonads of workers and drones, but not in the ovaries of virgin and egg-laying queens where hex $70 \mathrm{a}$ expression is maintained, although at a low level, throughout the adult stage.

In summary, the presence of hexamerin transcripts in larval and pupal gonads of workers, drones and queens 


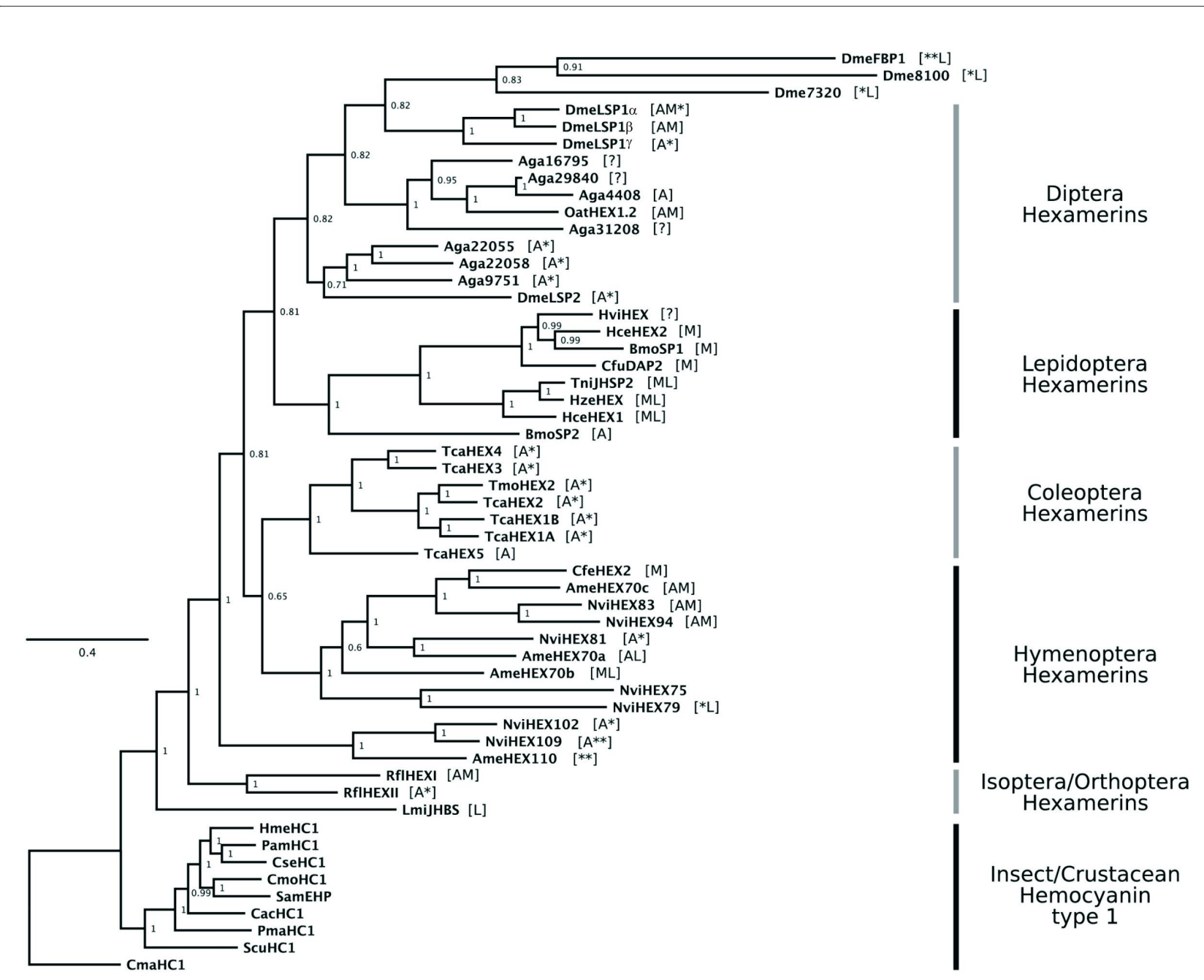

Figure 4 Evolutionary relationships among insect hexamerins and hemocyanins. The phylogenetic tree was inferred by bayesian method and the posterior probabilities are represented at each node. [See Additional data for the accession numbers of hexamerins and hemocyanins included in the tree (file 14), and for the alignment use in tree reconstruction (file 15)]. Symbols and letters in brackets indicate: ** very high-Glx content ( $>15 \%)$; * high-Glx content (between 10\% and 15\%); A: arylphorin; M: methionine-rich; L: leucine-rich; ? indicates that amino acid composition could not be determined. The first three letters of the protein's abbreviation represent the species: Cma:Cancer magister; Scu: Sinella curviseta; Pma:Perla marginata; Cac: Chelidurella acanthopygia; Sam: Schistocerca americana; Cmo: Carausius morosus; Cse: Cryptotermes secundus; Pam: Periplaneta americana; Hme: Hierodula membranacea; Rfl: Reticuliformis flavipes; Lmi: Locusta migratoria; Ame: Apis mellifera; Nvi: Nasonia vitripennis; Cfe: Camponotus festinatus; Tca: Tenebrio castaneum; Tmo: Tenebrio molitor; Bmo: Bombyx mori; Hce: Hyalophora cecropia; Hze: Helicoverpa zea; Tni: Trichoplusia ni; Cfu: Choristoneura fumiferana; Hce: Hyalophora cecropia; Hvi: Heliothis virescens; Dme: Drosophila melanogaster; Aga: Anopheles gambiae; Oat:Ochlerotatus atropalpus.

suggests roles in ovary and testis development, and in spermatogenesis, which occurs during the pupal stage. The higher expression of hex 110 in the ovaries of egglaying than virgin queens is remarkable, and suggests a function in reproduction.

\section{Discussion}

\section{Hexamerin genes and deduced proteins revealed striking structural differences}

The tandem organization of the hex $70 a, 70 b$ and $70 c$ genes in the honey bee genome supports the hypothesis of origin by gene duplication, a common phenomenon among insect hexamerins [27]. The separately located hex 110 gene exhibits unusual features throughout its sequence. It encodes a subunit that is longer than those usually found, and which carries a very high proportion of Glx (20.9\%). Because these features are also displayed by hexamerins found in some species of ants [28] and wasps [29], it had been previously thought that they were restricted to hymenopterans. In fact, two hexamerins in the N. vitripennis wasp (NviHEX102 and NviHEX109) exhibit such characteristics (see Figure 4). However, a receptor in Drosophila, DmFBP1 (which is closely related to its own ligand DmLSP1) [30], is also composed by a 
Expression in the fat body
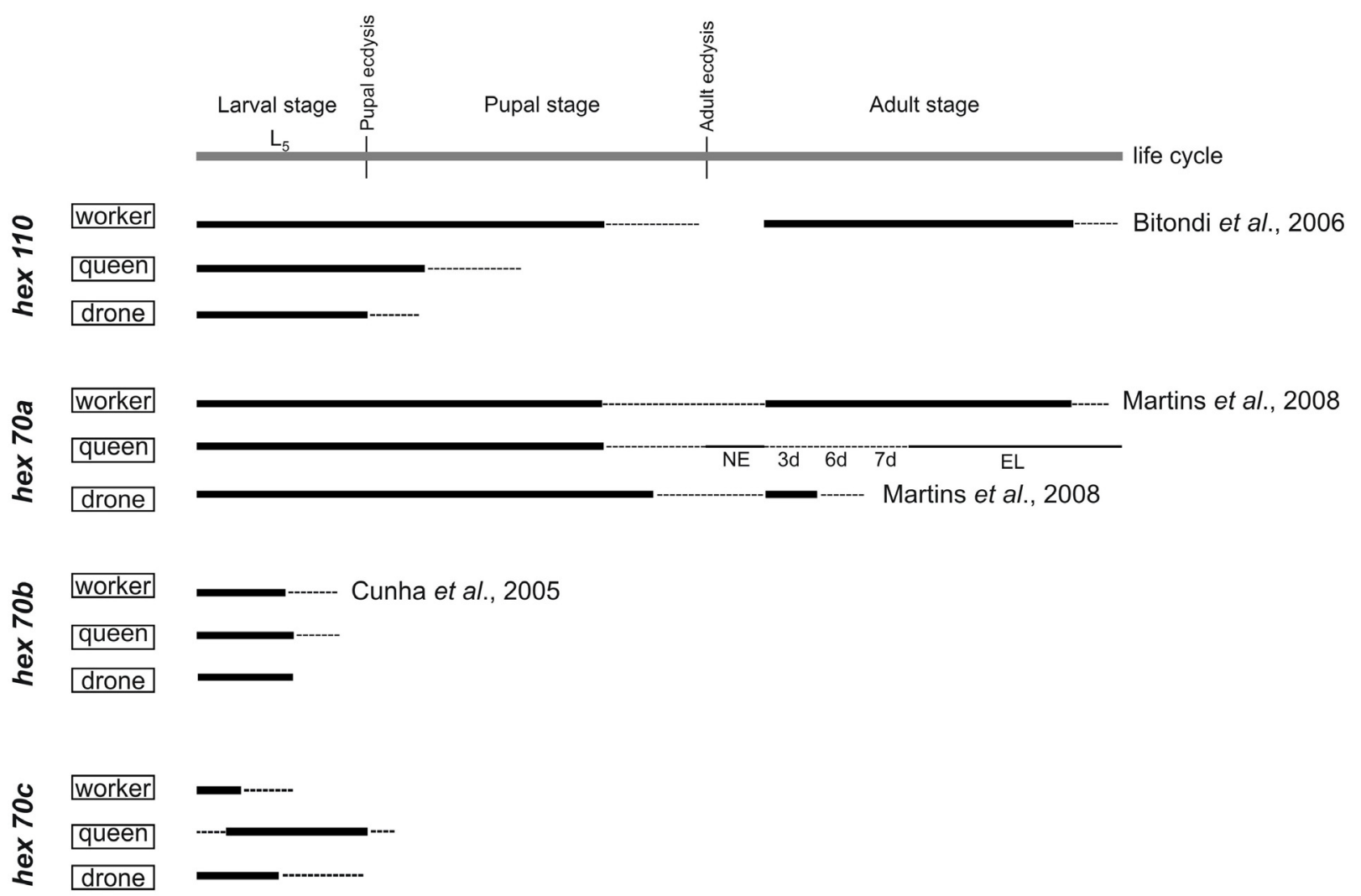

Figure 5 Patterns of hexamerin gene expression in the fat body of immature and adult stages of workers, queens and drones. The simplified diagrams represent expression patterns based on hexamerin transcript abundance as detected by RT-PCR followed by electrophoresis of the amplified cDNA on ethidium bromide-stained agarose gels using A. mellifera actin as a loading control (see Additional file 11). The thick, thin and dashed lines in the diagrams represent high, intermediary and low transcript levels, respectively. L5: 5th larval instar. L5F and L5S: feeding and spinning phases of the 5 th larval instar. NE: newly emerged queens. EL: egg-laying queens. 3d, 6d, and 7d: adult age in days. Data previously published by our laboratory are indicated by the respective bibliographic reference.

very high Glx content (20\%) and has a high molecular mass $(116 \mathrm{kDa})$. We also identified hexamerins containing slightly lower Glx percentages (between 10\% and 15\%) among the dipterans, coleopterans and in the isopteran included in the tree (see Figure 4). The physiological significance of such a high proportion of glutamine and glutamic acid in hexamerins remains to be elucidated.

A conserved histidine residue was identified in each of the four amino acid sequences. In the ancestral hemocyanins, six copper-liganding histidines confer the ability to bind and transport oxygen. The insect hexamerins lost most or all of the histidine residues and, thus, the oxygenbinding function [31].

The $\sim 70 \mathrm{kDa}$ hexamerins in the honey bee were classified as arylphorins and/or methionine-rich, according to their particular amino acid composition. Due to the importance of aromatic amino acids in sclerotization, the HEX 70a and HEX 70c arylphorins may contribute to exoskeleton hardening and differentiation during pharate adult development. HEX 70c is also rich in methionine, and like HEX 70b (also a methionine-rich hexamerin) it may act as a sulfur reserve for development toward the adult stage.

The search for cis-acting elements in the UCR of each hexamerin gene using bioinformatic analyses revealed a total of six overrepresented DNA motifs. It was very interesting to find out that all four hexamerin genes exhibit potential binding sites for the protein Usp, thus suggesting regulation by $\mathrm{JH}$ and/or ecdysteroids. Usp has been primarily studied as part of the 20-hydroxyecdysone (20E)-binding nuclear receptor complex [32,33]. However it was recently also identified as a potential target for compounds based on a methyl farnesoid structure, like $\mathrm{JH}$ [34]. The potential Usp binding motif is located near the start codon of each hexamerin gene (see Figure 2A), a conserved pattern that increases the likelihood of its functionality. Using a hormone manipulation experi- 


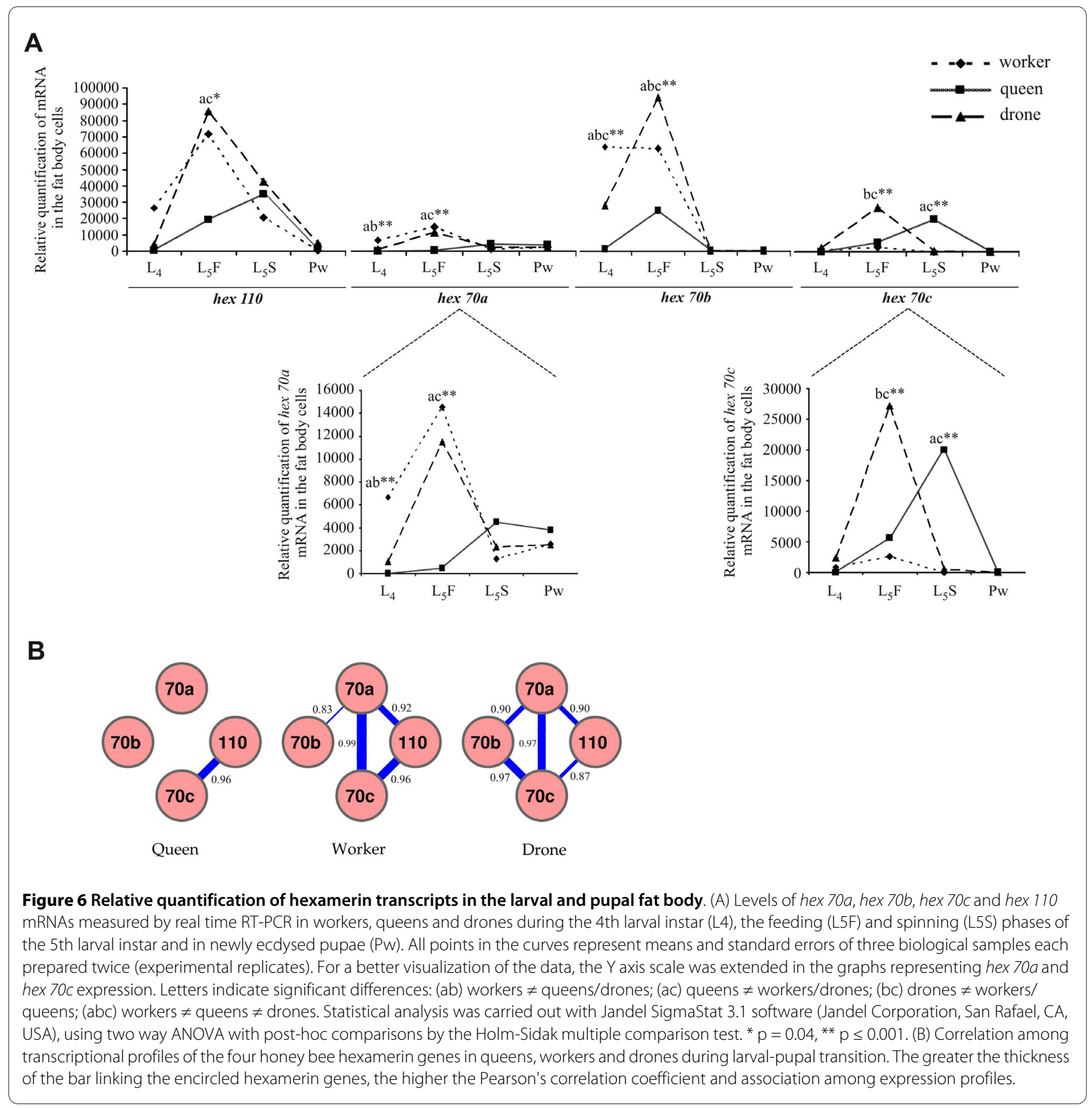

ment, we recently demonstrated that hex $70 \mathrm{~b}$ is induced by $\mathrm{JH}$ and repressed by $20 \mathrm{E}$ [19]. In the current study we expanded this experiment to investigate the action of $\mathrm{JH}$ on the expression of the other honey bee hexamerin genes. To make this approach comparative, we re-tested the expression of hex $70 \mathrm{~b}$ in the same fat body samples used for the analysis of the other genes. The results showed a strong and positive $\mathrm{JH}$-influence on the expression of hex $70 b$ and hex $70 c$, and a weaker effect on the expression of hex $70 a$ and hex 110. The observed differential effect of $\mathrm{JH}$ on expression levels suggests that the $\mathrm{JH}$ titer that induces a hexamerin gene for maximal expression may differ from the JH-threshold needed for maximal expression of their homologous. Further studies using a series of $\mathrm{JH}$ doses for treating aged-synchronized honey bee larvae may confirm (or refute) this hypothesis. These results are in accord with the proposed functionality of the Usp regulatory element in UCRs.

In addition to the potential Usp binding motif, five additional motifs (site 2 to site6) were overrepresented in the UCRs of all four hexamerin genes, suggesting co-regulation. In the context of metamorphosis, or larval-pupal transition, this would assure the massive and synchronized production of hexamerins in late larvae for using 


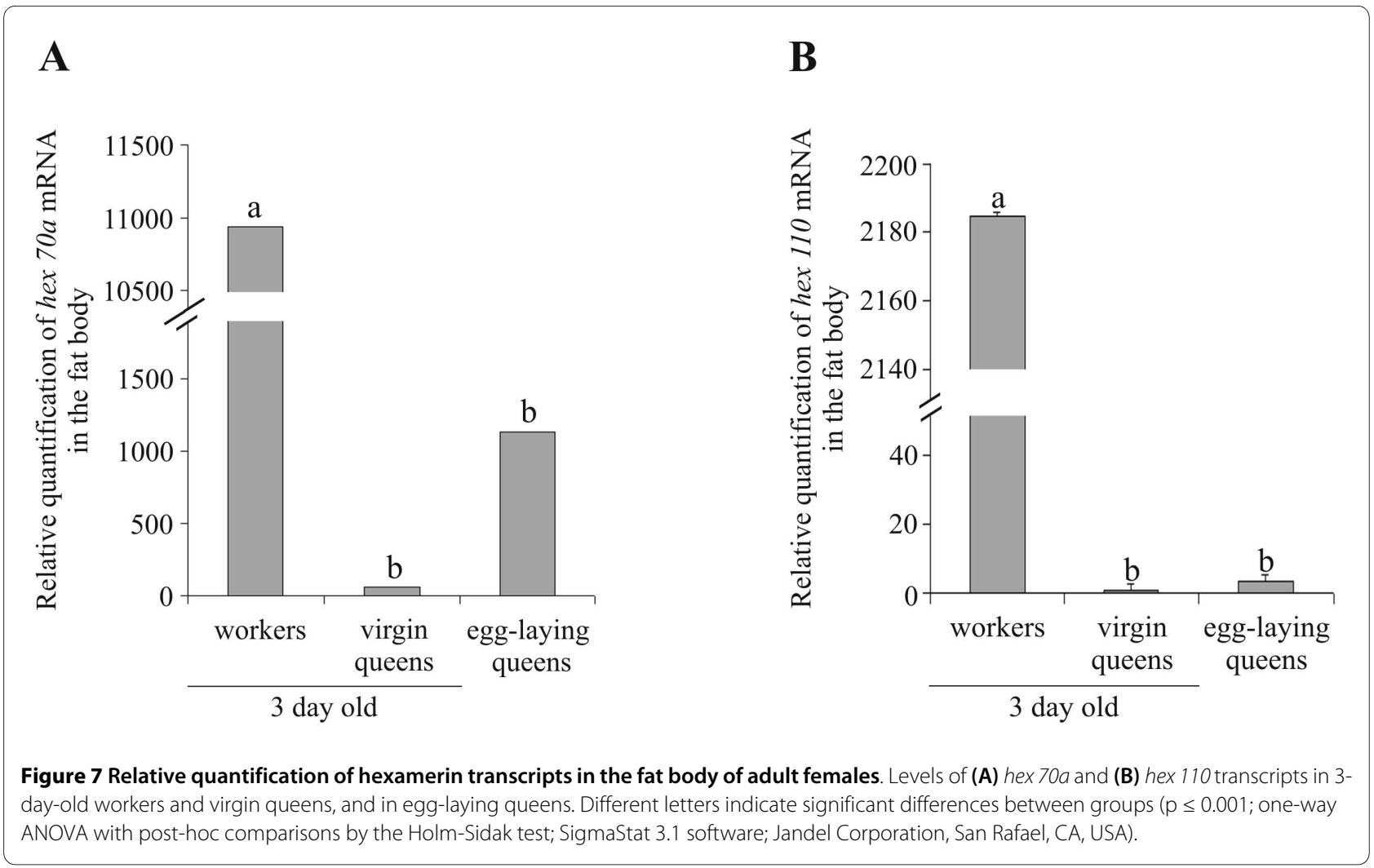

during pupal and pharate-adult development. In fact, all four hexamerin genes reached their highest expression level during the very same stage, the 5th larval instar (see Figure 6A). Lending support to the idea of co-regulation, we found that the transcriptional profiles of the hexamerin genes in each caste and sex during the larval-pupal transition are in general positively correlated. Regulatory factors could interact with the common sequence motifs, thus influencing the correlated expression. However, the transcriptional profiles of hex $70 \mathrm{~b} /$ hex 110 in workers and drones, and of hex 70b/hex 70c in workers, did not show a positive correlation (see Figure 6B). Furthermore, in metamorphosing queens, only the hex $70 c$ and hex 110 transcriptional profiles showed a significant Pearson's correlation coefficient. Such differences might be due to structural features in the architecture of each hexamerin gene UCR, such as the type, number and spatial distribution of the overrepresented motifs, which raises the possibility of nuanced differences in the co-regulatory mechanism.

\section{Diversification of hexamerins associated with independent radiation within insect orders}

Based on amino acid sequence similarities and hexameric structure, it has been proposed that arthropod hemocyanins gave rise to the insect hexamerins [31,35], which lost the ability to bind $\mathrm{Cu} 2+$ ions. Therefore, in contrast to the ancestral molecule, hexamerins do not bind and deliver hemolymph oxygen, but mainly have a role as storage proteins. The molecular phylogeny shown in Figure 4 shows a complex pattern of hexamerin evolution, with independent radiation in each of the selected insect orders. In general, our analysis resulted in a similar tree topology as those published before [36], with the hemimetabola (orthopteran and isopteran) hexamerins in a basal position, followed by hymenopteran and coleopteran hexamerins, which are basal to the lepidopteran and dipteran ones. As previously noticed, these evolutionary relationships are in good agreement with phylogeny of insect orders [37].

Most of the information on hexamerin evolution derives from studies on dipteran and lepidopteran species, with a few studies on other holometabolous and hemimetabolous orders, although data from an evolutionarily less-derived order (Plecoptera) have been recently published [38]. The main contribution of the current phylogenetic analysis was to explore the evolutionary relationship among the honey bee hexamerins and their homologue sequences in other insect orders. It is evident in our phylogenetic tree that the high molecular mass AmeHEX110 is located at the most basal position among the holometabola hexamerins. AmeHEX110 shares this position with two probable orthologues, NviHEX102 and NviHEX109. Similarly, the gene encoding AmeHEX70a apparently has an orthologue, NviHEX81, in the genome of $N$. vitripennis. Other poten- 


\section{Expression in developing gonads}
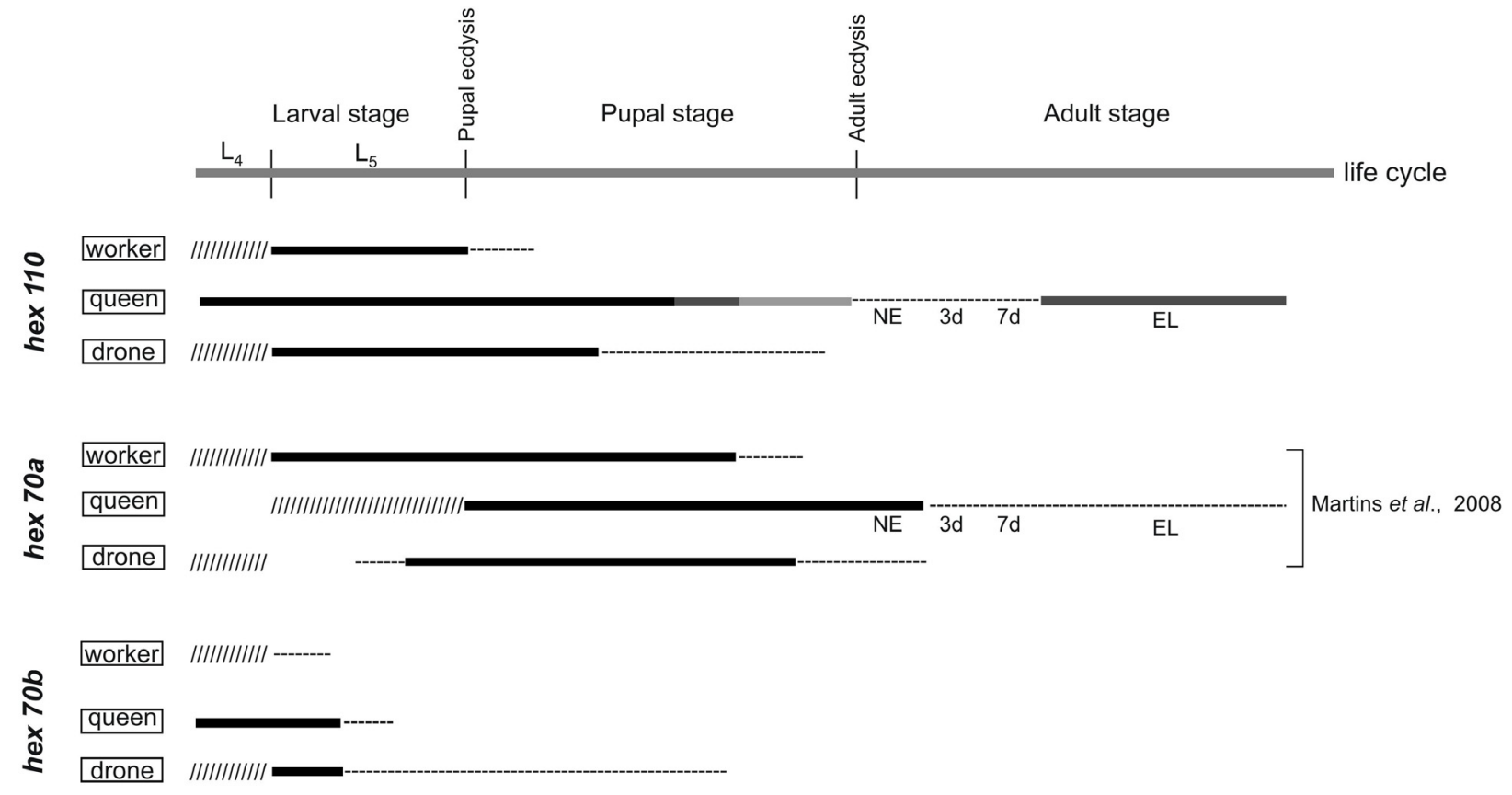

Figure 8 Patterns of hexamerin genes expression in the gonads of immature and adult stages of workers, queens and drones. The simplified diagrams represent expression patterns based on the hexamerin transcript abundance as detected by RT-PCR followed by electrophoresis of the amplified cDNA on ethidium bromide-stained agarose gels using A. mellifera actin as a housekeeping gene (see Additional file 12). The black, dark-grey, light-grey and dashed lines in the diagrams represent high, intermediary, low and very low transcript levels, respectively. Data not shown are indicated $(/ / / / /)$. L4 and L5: 4th and 5th larval instars. NE: newly emerged queens. EL: egg-laying queens. $3 \mathrm{~d}$ and 7d: adult age in days. Data previously published by our laboratory are indicated by the respective bibliographic reference.

tial orthology relationship was exhibited by the honey bee AmeHEX70c, and the ant CfeHEX2.

The molecular phylogeny also revealed a potential orthology relationship outside the hymenopteran clade, between the hexamerins from T. molitor, TmoHEX2, and T. castaneum, TcaHEX2, but a definitive conclusion would only be possible if $T$. molitor had its genome sequenced. For the lepidopteran hexamerin sequences it is more complicated to infer orthology relationships, at least until they were available in public databases. Orthology may be a reflection of functional equivalence, although it is important to consider that in view of gene loss and other events in evolution of a group of organisms, genes from different species sharing high sequence similarity may be not orthologues at all [39]. Functional studies are therefore decisive to elucidate this complex relationship among hexamerin genes.

A relevant observation taken from our molecular phylogeny is the well-supported split between dipteran hexamerins and the group formed by the hexamerin receptor DmeFBP1 and Dme8100 plus Dme7320 (0.82 posterior probability; Figure 4). It has already been suggested that dipteran hexamerin receptors, which also belong to the hemocyanin-hexamerin superfamily, form a separate group in phylogenetic trees [37]. Whether these other two DmeFBP1 paralogs have a similar function is still unknown.

It is also obvious that most of the lepidopteran hexamerins used in tree reconstruction are methionine-rich proteins, thus suggesting that they derived from an ancestral molecule containing a high proportion of this amino acid. We also observed that, except for AmeHEX110 every basal hexamerin in each insect order is an arylphorin, thus suggesting that insect hexamerins have evolved from an ancestral arylphorin. Our phylogenetic analysis also supports the hypothesis of gene duplication events taking place mainly after the split of insect orders.

Expression of hexamerin genes in larval fat body: the wellknown role in metamorphosis and a putative role in binding $\mathrm{JH}$ and regulating caste differentiation

The four hexamerin genes were highly transcribed in the larval fat body of workers, queens and drones, and are probably involved in hexamerin synthesis for amino acid storage to support metamorphosis and development 
toward the adult stage. However, these genes were differentially co-expressed in the honey bee morphotypes, as revealed by transcript quantification during the critical period of larval-pupal transition. The most evident difference occurred during the feeding phase of the 5 th larval instar (L5F), where we observed a higher level of hex 110, hex $70 a$ and hex $70 b$ transcripts in workers and drones than in queens. This is a very interesting finding if contrasted to the caste and sex-specific JH titer at this stage, which is higher in queens than in workers and drones $[26,40]$. It is known that JH plays a central role in phenotypic caste differentiation in A. mellifera. This hormone triggers specific physiological responses in the bipotent female larvae, a high titer inducing development of a queen and a low titer specifying the worker phenotype $[41,42]$. The inverse relationship between levels of hexamerin transcripts and $\mathrm{JH}$ titers leads us to speculate that, as was proposed for the termite Reticulitermis flavipes $[14,15,43,44]$, the honey bee hexamerins may function as $\mathrm{JH}$-binding proteins. By binding and controlling $\mathrm{JH}$ levels, hexamerins were implicated in the process of $\mathrm{JH}$-dependent caste differentiation in this termite. By applying this model to the honey bee, we may hypothesize that if $\mathrm{JH}$ titer exceeded the binding capacity of hexamerins, it would interact with target receptors and therefore cause the bipotent female larva to develop as a queen. If not, the larva would develop as a worker. Interestingly, all the four hexamerin genes showed a significantly higher expression in drone feeding larvae (low $\mathrm{JH}$ titer) than in queens at the same stage (high $\mathrm{JH}$ titer), thus reinforcing our hypothesis on a role for the honey bee hexamerins in binding and controlling $\mathrm{JH}$ action. But this needs further validation.

To our knowledge, hexameric JH-binding proteins have been characterized only in orthopterans [2,3,45]. The cDNA and predicted amino acid sequences of the high affinity JH-binding hexamerin from L. migratoria (LmiJHBS) show peculiar structural features. It is clear that LmiJHBS is not closely related to any other hexamerin, including the potential $\mathrm{JH}$-binding hexamerin from $R$. flavipes (RfHEX1) and the honey bee hexamerins (see Figure 4). The lack of homology clearly indicates that these hexamerins have evolved independently, and it is unlikely that comparisons among their primary sequences will bring to light amino acid regions or domains that could be involved in $\mathrm{JH}$ binding. Such regions or domains could not be identified in the LmJHBS sequence [3]. Thus, functional binding assays and determination of dissociation constants are required to assess the potential role of hexamerins in binding $\mathrm{JH}$ and, by extension, to verify the role of the honey bee hexamerins in caste determination.

An interesting finding is that insect hexamerins may not directly bind $\mathrm{JH}$ but may be part of a multiprotein complex engaged in $\mathrm{JH}$ sequestration and transport. The first demonstration of a physical interaction among $\mathrm{JH}$ binding proteins (both free and in a complex with $\mathrm{JH}$ ), two hexamerins (one of them is an arylphorin), and an apolipophorin was recently provided [46]. This interaction implies an important participation of hexamerins in regulating $\mathrm{JH}$ levels, and action, even if they do not directly bind to $\mathrm{JH}$.

\section{Re-induction of hexamerin gene expression in the adult fat body: differential roles in workers and queens}

In agreement with previous reports on hemolymph proteins in the honey bee $[23,47]$, lower levels of hexamerin gene expression were found in adult workers in comparison to larvae. Of the four hexamerin genes, hex $70 a$ and hex 110 were the only ones with detectable expression in the adult fat body. Their transcriptional profiles differed conspicuously among adult queens, drones and workers. Levels of hex $70 a$ transcripts were very low in queens and abundant in drones and workers. However, in drones, the abundance is limited to the five first post-emergence days, whereas, in workers, it is extended up to the 30th day of adult life. These transcriptional profiles in workers and drones match the respective HEX 70a profiles in hemolymph [21], and are closely connected with adult life duration. Workers live longer than drones [48,49], and their respective patterns of hex $70 a$ expression reflects fat body metabolic activity and lifespan. But the higher expression of hex $70 a$ in the fat body of adult workers in comparison to queens (see Figures 5 and 7) suggests an important role in worker physiology. This is discussed below.

The expression of hex 110 is somewhat different when compared to that of hex 70a. Like hex 70a, the hex 110 gene is considerably active in the fat body of adult workers, but it is practically silent in queens (see Figures 5 and 7) and drones (see Figure 5). Yet, in spite of the evident presence of hex 110 transcripts in adult workers, a negligible amount of HEX 110 subunits were detected in hemolymph [20], indicating that this hexamerin does not function as a storage protein at this stage. But a potential function in the fat body of adult workers cannot be ruled out, given its specific and abundant expression in this tissue.

Our results are consistent with re-induction of hex $70 a$ and hex 110 expression in adult bees, although only the product of hex $70 a$ accumulates in hemolymph at this stage. The presence of hexamerins in adult insects may occur either because they were carried over from the larval stage, or due to a specific induction in adults. As examples, some lepidopterans that do not feed on protein as adults may use the larval store of hexamerins for egg production [5]; mRNAs for an adult-specific hexamerin appears in Musca domestica females only after induction 
by a rich protein meal [50]. Differently, the presence of HEX 70a in the adult honey bee results from gene reinduction after a drastic reduction in transcript levels during adult ecdysis (see Figure 5).

The honey bee queen continuously receives, via trophallaxis, a proteinaceous glandular secretion, the royal jelly, which is produced by nurse workers [51]. She may not need to allocate amino acids from larval hexamerins for egg production, since such compounds are continuously derived from her protein-enriched diet. The structural nutrients and energy contained in royal jelly administered to queens are not used for the synthesis and storage of hexamerins (levels of hexamerin transcripts are very low, or undetectable, in the fat body of adult queens; see Figures 5 and 7) but must be mainly directed to vitellogenesis and egg production. In contrast to the queen, workers normally do not produce eggs, although they also have access to a rich source of dietary proteins. They actively consume pollen when they are younger, i.e., during the first two weeks of adult life [52]. Pollen consumption increases the expression of hex $70 a$ and hex 110 in the fat body, and increases the abundance of HEX 70a in hemolymph [20,21]. This is consistent with dietary protein consumption causing reinduction of both hexamerin genes in adult workers, and thereby enabling the storage of HEX 70a. Whether hex 110 mRNAs are translated and, if so, why their subunits do not accumulate in hemolymph are questions that remain unanswered.

Pollen consumption also causes the accumulation of vitellogenin, the yolk protein precursor, in the hemolymph of young workers [53]. Vitellogenin is continuously produced and stored in hemolymph during the first two weeks of adulthood to be subsequently depleted as worker bees get older and become foragers [54-57]. HEX 70a follows a similar pattern.

Since workers normally do not reproduce and in general have a short life, the question that remains unanswered is: why do they store proteins? We suggest that the consumption of pollen by young workers exceeds demand, and the excess is hoarded in the form of storage proteins to be consumed later, when they become foragers. Foragers rather eat nectar [58], which is composed primarily by carbohydrates [59]. By this means, stored proteins could provide amino acids for sustaining worker basal metabolism during foraging. The well documented observations that HEX 70a [21], vitellogenin [55-57], and total hemolymph protein titers [60] decrease gradually in foragers is consistent with this hypothesis.

The destination of proteins stored in worker hemolymph would not be fixed, but dependent on the social context. In case there is queen loss, workers may activate their ovaries for drone production. Their protein reserves would then be directed to meet reproduction demands. Interestingly, workers accumulate storage proteins when they are younger and more prone to activate their ovaries if separated from the queen. Also in the ant Camponotus festinatus, hexamerins are possibly involved in important facets of sociality. It was demonstrated that in the presence of larvae, adult workers do not store, but apparently make use of hexamerins to nourish larvae. Conversely, hexamerins accumulate in hemolymph of workers with no larvae to feed. It was also observed that hexamerins exist in great amounts in virgin queens and are depleted when they seal themselves in a chamber to lay eggs to found a new colony, thus indicating utilization for egg production and rearing the first brood [11,12]. The high levels of hexamerins stored by certain species of termites were also found to be related to colony founding and to the production of initial broods [13].

In adult honey bee workers, vitellogenin and HEX 70a may be part of the above mentioned multiprotein complex engaged in $\mathrm{JH}$ binding and sequestration [46], since the presence of both in hemolymph coincides with a low $\mathrm{JH}$ titer (in younger workers), and their depletion occurs in synergy with $\mathrm{JH}$ titer increase (in foragers). If so, as proposed for vitellogenin [61], HEX 70a also may be a player in the physiological process of $\mathrm{JH}$-regulated transition to forager.

Yet, HEX 70a may have developed another role in adult workers. A protein fragment found in the honey bee venom [62] matched HEX 70a N-terminal sequence. Its function in the venom, and whether it is synthesized by the venom gland or sequestered from hemolymph, was not yet determined.

\section{Hexamerin gene expression in gonads: a proposed role in ovary and testis development and activity}

Among solitary insects there is circumstantial evidence supporting the hypothesis that hexamerins are also used for reproduction. In lepidopteran species, for example, it was established a correlation between egg production and depletion of the larval reserve of hexamerins $[4,5]$. Autogenous mosquitoes that produce their first batch of eggs without a feeding may use larval storage proteins, mainly hexamerins, as amino acid source for this purpose $[6,7]$. It has also been suggested that amino acids held in storage proteins are used for provisioning eggs of Schistocerca americana [8].

To shed light on whether the "adult" honey bee hexamerins are important or not for reproduction, we checked for the presence of transcripts in the gonads. Except for hex 70c, hexamerin transcripts were abundant in the gonads of larvae and pupae, suggesting roles in ovary differentiation, and also in spermatogenesis, which in drones occurs during pupal stage and is finalized before adult emergence. Two of the hexamerin genes, hex $70 a$ and hex 110, were also expressed in adult gonads, and this was exclusively in queen ovaries. Interestingly, the 
expression of hex 110 is higher in the ovaries of mated, egg-laying queens than in the young, virgin ones.

It is known that mating triggers changes in gene expression in Drosophila females [63]. Mating also elicits physiological and behavioral changes in honey bee queens, and although the molecular mechanisms underlying such responses are largely unknown, it was verified that they involve differential gene expression into the ovaries. Based on gene ontology annotation, a function in oogenesis and reproduction was attributed to these differentially expressed genes [64]. The high expression of hex 110 in the ovaries of egg-laying queens suggests a role linked to ovary activity and reproduction.

Ovaries of egg-laying queens have a lower level of hex $70 a$ transcripts than ovaries of newly emerged ones. But HEX 70a subunits exist in equivalent amounts in the ovaries of both, newly emerged and egg-laying queens, as confirmed by Western blots using a specific antibody [21]. Therefore, ovarian HEX 70a molecules seem to have a dual origin. It is produced by the fat body of egg-laying queens (see Figure 5) and secreted in hemolymph [21,23], implying that it could be incorporated into the ovaries in addition to being synthesized by them. The function of HEX 70a in the ovaries of virgin and egg-laying queens is to be determined.

\section{Conclusions}

Our study revealed dramatic differences in structure, organization and expression of the four hexamerin genes of the honey bee, where these differences might have arisen concurrently with their functional diversification. The amino acid composition, motifs and conserved regions were identified in the deduced protein subunits, which were also used in a phylogenetic analysis to explore their evolutionary relationship with homologue sequences of other insect species. Analyses of the UCR of each hexamerin gene revealed a total of six overrepresented DNA motifs, indicating co-regulation. One of these motifs is a potential binding site for the protein Usp, and suggested gene regulation by JH. This hypothesis was reinforced by manipulating $\mathrm{JH}$-levels in experiments in vivo, which resulted in JH-induction of the expression of hexamerin genes in larval fat body. Apparently under a high dietary protein input as occurring during larval stage, $\mathrm{JH}$ induces hexamerins for a high expression.

The detailed expression studies using fat body, ovaries and testes revealed that: (1) the four hexamerin genes are highly transcribed in the larval fat body, and are likely involved in hexamerin synthesis for amino acid storage and use during pupal stage; (2) in young adult workers, the expression of hex $70 a$ in the fat body is in accordance with the idea of amino acid storage for a later support of foraging; (3) the expression of hexamerin genes in larval and pupal gonads suggests a role in ovaries and testes differentiation, and in spermatogenesis; (4) the expression of hex 110 in the ovaries of egg-laying queens, was associated with ovary activity for egg production; (5) at definite points of the honey bee development, the inverse relationship between the fat body levels of hexamerin transcripts and $\mathrm{JH}$ titer suggests that hexamerins regulate $\mathrm{JH}$ availability and, consequently, may be involved in the processes of caste-differentiation and worker transition to foraging.

Together, the findings of the present study are significant in that they highlighted the potential participation of hexamerins in important aspects of the life cycle of a social insect, in addition to their primordial role in metamorphosis.

\section{Methods \\ Honey bees}

Africanized honey bees were collected from hives maintained at the apiary of the University of São Paulo in Ribeirão Preto, Brazil. Developing queens (reared by standard apicultural procedures), workers and drones were staged according to Rembold et al [65], Michelette and Soares [66], and Tozetto et al [67], respectively. Adult workers and drones of known ages were obtained by paint marking the newly emerged ones and returning them to their hives to be collected a specified number of days later. Adult virgin queens were used at the third day after emergence, and egg-laying queens of unknown ages were collected from colonies kept in our apiary.

\section{Fat body and gonad samples used in hexamerin expression studies}

Transcripts for the four hexamerin genes were assessed in the fat body of workers, queens and drones collected at different ontogenetic stages (larval, pupal and adult). Larvae were collected at the $4^{\text {th }}$ and $5^{\text {th }}$ instars, and individually sampled for total RNA extraction. As at the $4^{\text {th }}$ instar the fat body removed by dissection frequently resulted in small quantities of total RNA, we opted to use the whole larvae as fat body source. To optimize comparisons within larval stage, the same was done for the $5^{\text {th }}$ instar larvae. The abdominal carcass (dorsal integument and subjacent fat body) from pupae, pharate-adults and adults was sufficient to obtain individual RNA amounts, and then it was used as fat body source. Expression was also investigated in the ovaries of queens and workers, and in the testes of drones, during pre-imaginal and adult stages. Ovaries and testes were carefully dissected and exhaustively washed in Ringer saline to eliminate contaminant fat body before being used for RNA extractions. Data from our laboratory concerning hex 110 [20], hex 70b [19] and hex 70a [21] gene expression in the worker fat 
body, and concerning that of hex $70 a[21]$ in female and male gonads, were used for comparisons.

\section{Testing the effect of $\mathrm{JH}$ on the expression of hexamerin genes}

To test the effect of $\mathrm{JH}$ on the expression of hexamerin genes, a commercial JH III (Fluka) was diluted in acetone to make $10 \mu \mathrm{g}$ per $\mu \mathrm{l}$, and $1 \mu \mathrm{l}$ was topically applied on $5^{\text {th }}$ instar worker larvae at the feeding phase (L5F). Control larvae at the same age were topically treated with $1 \mu$ acetone. To obtain age-controlled worker larvae, the queen was caged on a comb and left to lay eggs for $6 \mathrm{~h}$. When age-synchronized larvae reached the L5F stage, the comb was retrieved from the hive and transported to the laboratory for hormone treatment. The hormone (or acetone only) was carefully deposited on each larva in its comb cell using a micropipette. In this occasion, the comb was mapped for further identification of treated and control larvae, and thereafter they were returned to the hive. Treated and control larvae were collected after $24 \mathrm{~h}$ for RT-PCR analyses.

\section{Characterization of hexamerin coding sequences (CDSs)}

The previously described $\mathrm{N}$-terminal sequences of two of the honey bee hexamerins, HEX 70c (AYYAGRHTADMFFLH) and HEX 110 (APNVKQRAADQDLLNKQQDVIQLLQKISQPIPNQELQNLG) [23], were individually aligned against the Official Gene Set database [68,69]. Matching predicted amino acid sequences (GB13613-PA and GB14361-PA) were identified, and the corresponding nucleotide sequences (GB13613-RA and GB14361-RA) were annotated in the Artemis 7.0 platform [22] and used to design primers for experimental determination of the complete hex 70c and hex 110 CDSs (a short hex 110 cDNA fragment of 180 bp had been previously cloned and sequenced by our research group, [20]). The primers [hex 70c (PIR and 3F; 2R and PIF), and hex 110 (5R and 2F; 2R and $0 \mathrm{~F}$ )] (see Additional file 13) were combined for PCR amplification from first-strand cDNAs obtained by reverse transcription (see RT-PCR analysis below) of total RNA from 5th instar worker larvae.

Amplicons were purified and subcloned using the TOPO TA-cloning kit (Invitrogen). Insert-containing plasmids were subjected to sequencing reactions using the primers described in Additional file 1 and M13-forward and reverse universal primers. Dideoxy sequencing was performed in an automatic sequencer (ABI Prism 310, Applied Biosystems) using BigDye Terminator v3.0 Cycle Sequencing Reaction (Applied Biosystems). Sequences were analyzed using Sequencher (version 4.7, Gene Codes Corporation), Artemis software and BLAST algorithms.

For purposes of data comparison, we used the hex $70 \mathrm{~b}$ CDS, and the hex 70a CDS plus part of its 5' and 3' UTRs previously cloned and sequenced by our research group ([19,21]; see Additional file 14 for the accession numbers).

\section{Characterization of potential regulatory sequences in UCRs}

A pipeline for motif discovery was designed based on reliable strategies previously proposed by MacIsaac et al [70], and adapted to analyze the honey bee genome $[71,72]$. This pipeline integrates three motif-detection programs: AlignAce [73], MEME [74] and MDscan [75]. Honey bee intergenic databases were constructed for 1.5, 3 and $6 \mathrm{~kb}$ sequence sizes that were trimmed whenever another open reading frame (ORF) was found to be flanking these regions. These databases were exploited for score calculations using group specificity scores (Church scores) [76], ROC-AUC scores [77] and Enrichment scores [78]. Two additional specific score metrics, the MAP score from AlignAce and MDscan and the E-value from MEME, were also used as a first filter for selecting the most significant motifs (MAP $>5$ and E-value $\leq 1 \mathrm{e}$ $05)$. The second filter was set up to decrease the amount of spurious hits among the identified DNA motifs (Church $\leq 1 \mathrm{e}-04$, ROC-AUC $\geq 0.7$ and P-value for enrichment $\leq 1 \mathrm{e}-04)$. The main criterion for identifying known regulatory sites among the six overrepresented motifs was the alignment of the PSSM (Position-Specific Scoring Matrix) for each hexamerin motif with the D. melanogaster sites as described in the TRANSFAC database, version 2008.2 [79]. Only the alignments passing a threshold of $80 \%$ identity for each PSSM were considered as significant matches. The correlation among hexamerin transcription profiles in developing queens, workers and drones, and the occurrence of DNA motifs in hexamerin gene UCRs were represented as networks based on concepts from graph theory [80] and complex networks $[81,82]$.

\section{Molecular phylogenetic analysis}

Hexamerins and hemocyanins were searched for in public databases of protein sequences (Additional file 14) by using HMMER [83] for identifying the hemocyanin C (PF03723.5), N (PF03722.5) and M (PF00372.10) domains as described in the Pfam database [84]. A multiple alignment was performed using Muscle [85] with default parameters (Additional file 15). The phylogenetic tree was reconstructed by bayesian inference (MrBayes v3.1.2) using the Blosum model and gamma distribution of substitution rates. Metropolis-coupled Markov chain Monte Carlo sampling was performed (with one cold and three heated chains) setting the number of generations to 300,000 and trees were sampled every $100^{\text {th }}$ generations. The average standard deviation of split frequency was 0.005 after 300,000 generations. The posterior probabilities were estimated by discarding the first $30 \%$ samples. 


\section{RT-PCR analysis}

The expression of hexamerin genes was evaluated in the fat body and gonads of developing queens, workers and drones by semi-quantitative RT-PCR using specific primers (hex 110: 2F and 2R; hex 70b: RT-PCR-F and RT-PCR$\mathrm{R}$; hex 70c: JUF and JUR, see Additional file 13) to generate 659, 456 and 171 bp cDNA fragments, respectively. Total RNA was extracted from fat body, ovaries and testes using Trizol reagent (Invitrogen). The RNA concentration of each extracted sample was measured using a GeneQuant spectrophotometer (Pharmacia). Purity was determined by the $260 / 280 \mathrm{~nm}$ ratio considering values between 1.8 and 2. RNA integrity was verified using denaturing agarose gel (1.2\%) electrophoresis and ethidium bromide staining. RNA samples were incubated at $37^{\circ} \mathrm{C}$ in the presence of 3 units of RNase-free DNase (Promega) for $40 \mathrm{~min}$ to eliminate contaminant DNA, followed by $15 \mathrm{~min}$ at $70^{\circ} \mathrm{C}$ to inactivate the enzyme. Firststrand cDNA was synthesized by reverse transcription using $2.5 \mu \mathrm{g}$ of total RNA, SuperScript II reverse transcriptase and an oligo $\mathrm{dT}(12-18)$ primer (Invitrogen). Negative control reactions without the enzyme were also prepared in parallel. After establishing the adequate number of cycles to avoid saturation, aliquots of cDNAs diluted 1:5 (v/v) in water were subjected to PCR (27 cycles of $30 \mathrm{~s}$ at $94^{\circ} \mathrm{C}, 1 \mathrm{~min}$ at $58^{\circ} \mathrm{C}$ and $1 \mathrm{~min}$ at $72^{\circ} \mathrm{C}$ ). The amplified products were analyzed by electrophoresis in $1.2 \%$ agarose gels containing ethidium bromide. An $A$. mellifera actin gene (GenBank accession number AB023025), which is constitutively expressed during development [86], was used to control for cDNA loading. The primers used for actin gene amplification were ACT - F and ACT - R (Additional file 13), and the thermal cycling program was the same as described above. Primer pairs used in RT-PCR analysis (as well as those specified in Additional file 13) were designed to span at least one intron. Therefore, possible contamination by genomic DNA in RT-PCRs could be easily identified by the detection of a distinct, larger, band following electrophoresis in ethidium bromide-stained agarose gels.

\section{Real-time RT-PCR analysis}

In order to quantitatively compare the levels of hexamerin transcripts in queens, workers and drones during the larval-pupal transition and in adults, we used the $\Delta \Delta \mathrm{C}_{\mathrm{T}}$ method where the relative amount of transcripts is given by $2^{-} \Delta \Delta C_{T}$ (Applied Biosystems User bulletin \#2; [87]). We previously performed validation experiments to verify the efficiencies of amplification of the targets and the endogenous reference. The rp 49 gene [GenBank:AF441189], which is expressed in similar levels during honey bee development [86] was used as the endogenous reference. Amplification of $r p 49$ was done with the primers $\mathrm{R}$ and $\mathrm{F}$ (Additional file 13). Specific primers were used to amplify hexamerin genes (hex 70a: RTR and RTF; hex 70c: 2F and 1R; hex 110: 3R and 4F; hex 70b: RTR and RTF; Additional file 13). Using serial cDNA dilutions, the efficiency $(\mathrm{E})$ of the reactions was calculated $\left(E=10^{(-1 / \text { slope })}\right)$ for each gene and showed to be approximately equal. Amplifications were conducted in a 7500 Real Time PCR System (Applied Biosystems) using $20 \mu \mathrm{L}$ reaction volumes containing $10 \mu \mathrm{L}$ SYBR Green Master Mix 2× (Applied Biosystems), $1 \mu \mathrm{L}$ first-strand cDNA $(0.25 \mu \mathrm{g} / \mu \mathrm{L}$, prepared from total RNA extracted from the fat body as described above for RT-PCR analysis), 7.4 $\mu \mathrm{L}$ water and 1 pmol of each specific primer. Reactions not including the SuperScript II reverse transcriptase (Invitrogen), or cDNA template, were prepared as negative controls. We used an initial cycle of $50^{\circ} \mathrm{C}$ for 2 min, a denaturation step of $95^{\circ} \mathrm{C}$ for $10 \mathrm{~min}$, followed by a two-step cycling condition $\left(40\right.$ cycles of $95^{\circ} \mathrm{C}$ for $15 \mathrm{~s}$, and $60^{\circ} \mathrm{C}$ for $1 \mathrm{~min}$ ). Each run was followed by a melting curve analysis to confirm the specificity of amplification and absence of primer dimers. To check reproducibility, each SYBR green assay was done in duplicate and repeated with three independent samples. Baseline and threshold were correctly set to obtain accurate $C_{T}$ values, which were exported into an MS Excel spreadsheet (Microsoft Inc.) for $2^{-\Delta \Delta C_{T}}$ calculations.

Pearson's Correlation Coefficient $\mathrm{R}$ was used to verify a possible association among the expression profiles of the four honey bee hexamerin genes in queens, workers and drones during the larval-pupal transition. The statistical significance of the $\mathrm{R}$ values was evaluated using a t-test, with $R>0.81$ indicating $95 \%$ confidence that the variables are truly correlated.

\section{Additional material}

Additional file 1 Complete coding sequence of the hex 110 gene.

Exons are separated by asterisks. Primer sequences used for expression studies and gene sequencing are underlined. hex 110 complete coding sequence.

Additional file $\mathbf{2}$ Complete coding sequence of the hex70a gene. Exons are separated by asterisks. Primer sequences used for expression studies and gene sequencing are underlined. Dashed lines indicate 5' and 3' UTR regions. hex70a complete coding sequence.

Additional file 3 Complete coding sequence of the hex $70 \mathrm{~b}$ gene. Exons are separated by asterisks. Primer sequences used for expression studies and gene sequencing are underlined. hex $70 b$ complete coding sequence.

Additional file 4 Complete coding sequence of the hex $70 \mathrm{c}$ gene. Exons are separated by asterisks. Primer sequences used for expression studies and gene sequencing are underlined. Dashed lines indicate 5' and 3' UTR regions. hex70c complete coding sequence. Additional file 5 HEX110 deduced amino acid sequence. Signal peptide is indicated by a dotted line, and a dashed line shows Danty's hexamerin motif [23]. Asterisks indicate glicosylation sites. The conserved histidine is double underlined. HEX 110 deduced amino acid sequence. 
Additional file $6 \mathrm{HEX70a}$ deduced amino acid sequence. Signal pep tide is indicated by a dotted line, and a dashed line shows Danty's hexamerin motif [23]. Asterisks indicate glicosylation sites. The conserved histidine is double underlined. LSP signature- 1 motif is indicated (+++). LSP signature- 2 motif is in bold. Protease cleavage site is underlined. The exopterygote and endopterygote conserved glycine14 is indicated (\#). HEX70a deduced amino acid sequence.

Additional file $7 \mathrm{HEX70b}$ deduced amino acid sequence. Signal peptide is indicated by a dotted line, and a dashed line shows Danty's hexamerin motif [23]. Asterisks indicate glicosylation sites. The conserved histidine is double underlined. LSP signature- 1 motif is indicated (+++). LSP signature- 2 motif is in bold. Protease cleavage site is underlined. The exopterygote and endopterygote conserved glycine14 is indicated (\#). HEX70b deduced amino acid sequence.

Additional file 8 HEX70c deduced amino acid sequence. Signal peptide is indicated by a dotted line, and a dashed line shows Danty's hexamerin motif [23]. Asterisks indicate glicosylation sites. The conserved histidine is double underlined. LSP signature- 1 motif is indicated (+++). LSP signature- 2 motif is in bold. The exopterygote and endopterygote conserved glycine-14 is indicated (\#). HEX70c deduced amino acid sequence.

Additional file $\mathbf{9}$ Hydropathy profiles produced for HEX70a, HEX70b HEX70c and HEX110 sequences using Phobius http://phobius.sbc.su.se Hydropathy profiles of the deduced hexamerin sequences of the honey bee.

Additional file 10 Multiple alignment including HEX 70a, HEX 70b, HEX 70c and HEX 110 using ClustalW 1.83. Multiple alignment of the deduced hexamerin sequences of the honey bee.

Additional file 11 Expression of hexamerin genes in the fat body of developing and adult workers, queens and drones. The abundance of hex 110, hex70a, hex70b and hex70c transcripts as detected by semiquantitative RT-PCR followed by electrophoresis of the amplified CDNA on ethidium bromide-stained agarose gel using an A. mellifera actin as a loading control. L5F and L5S: feeding and spinning phases of the 5th larval instar. PP: pharate pupae. Pw, Pp, Pdp, Pb, Pbl, Pbm and Pbd: successive phases of the worker and queen pupal stage. P1 to P13: successive phases of the drone pupal stage. NE: newlyemerged adults. Numbers indicate adult age in days. Expression of hex amerin genes in the fat body of developing and adult workers, queens and drones.

Additional file 12 Expression of hexamerin genes in the gonads of developing and adult workers, queens and drones. The abundance of hex 110 , hex $70 a$, hex $70 b$ and hex 70 c transcripts as detected by semiquantitative RT-PCR followed by electrophoresis of the amplified CDNA on ethidium bromide-stained agarose gel using an A. mellifera actin as a housekeeping gene. L5F and L5S: feeding and spinning phases of the 5th larval instar. PP: pharate pupae. Pw, Pp, Pb, Pbl, Pbm and Pbd: successive phases of the worker and queen pupal stage. P1 to P13: successive phases of the drone pupal stage. NE: newlyemerged adults. EL: egg-laying queens. Numbers indicate adult age in days. Expression of hexamerin genes in the gonads of developing and adult workers, queens and drones.

Additional file 13 Specific primers used for sequencing and expression analyses. as title.

Additional file 14 Accession numbers and references concerning to hexamerins and hemocyanins included in molecular phylogeny analysis. as title.

Additional file 15 Multiple alignment used for phylogenetic tree reconstruction. as title.

\section{Abbreviations}

CDNA: complementary DNA; RT-PCR: reverse transcription polymerase chain reaction; UCR: upstream control region; CDS: coding sequence; UTR: untranslated region; hex, hexamerin gene; HEX: hexamerin subunit; JH: juvenile hormone; DNAse: deoxyribonuclease; Glx: glutamine/glutamic acid; Usp: ultraspiracle.
Authors' contributions

JRM conducted the bioinformatic analyses, directed laboratory activities, undertook statistical analyses, interpretation of results and assisted with preparation of this manuscript. FMFN assisted with primers design, bioinformatic analyses, and manuscript edits. ASC conducted the bioinformatic and phylogenetic analyses and authored the corresponding Method and Result sections. ZLPS assisted with project design and development. MMGB conducted project design with considerable input into direction of research, interpretation of results and preparation of this manuscript. All authors read and approved the final manuscript.

\section{Acknowledgements}

The authors thank Luiz Roberto Aguiar for expert assistance in the apiary. Financial support was provided to ZLP Simões (05/03926-5) by the Fundação de Amparo à Pesquisa do Estado de São Paulo, which also provided a fellowship to JR Martins (08/00541-3).

\section{Author Details}

'Faculdade de Medicina de Ribeirão Preto, Departamento de Genética, Universidade de São Paulo, Ribeirão Preto, SP, Brazil, 2Faculdade de Filosofia, Ciências e Letras de Ribeirão Preto, Departamento de Biologia, Universidade de São Paulo, Ribeirão Preto, SP, Brazil and ${ }^{3}$ The Queensland Brain Institute, The University of Queensland, Brisbane, Queensland, Australia

Received: 15 May 2009 Accepted: 26 March 2010

Published: 26 March 2010

References

1. Burmester T, Scheller K: Ligands and receptors: common theme in insect storage protein transport. Naturwissenschaften 1999, 86:468-474.

2. Ismail SM, Gillott C: Identification, characterization, and developmental profile of a high molecular weight, juvenile hormone-binding protein in the hemolymph of the migratory grasshopper, Melanoplus sanguinipes. Arch Insect Biochem Physiol 1995, 29:415-430.

3. Braun RP, Wyatt GR: Sequence of the hexameric juvenile hormonebinding protein from the hemolymph of Locusta migratoria. J Biol Chem 1996, 271:31756-31762.

4. Pan ML, Telfer WH: Methionine-rich hexamerin and arylphorin as precursor reservoirs for reproduction and metamorphosis in female luna moths. Arch Insect Biochem Physiol 1996, 33:149-162.

5. Wheeler DE, Tuchinskaya II, Buck NA, Tabashnik BE: Hexameric storage proteins during metamorphosis and egg production in the diamondback moth, Plutella xylostella (Lepidoptera). J Insect Physiol 2000, 46:951-958.

6. Wheeler DE, Buck NA: A role for storage proteins in autogenous reproduction in Aedes atropalpus. J Insect Physio/ 1996, 42:961-966.

7. Zakharkin SO, Headley WV, Kumar NK, Buck NA, Wheeler DE, Benés H: Female-specific expression of a hexamerin gene in larvae of an autogenous mosquito. Eur J Biochem 2001, 268:5713-5722.

8. Hahn DA, Wheeler DE: Presence of a single abundant storage hexamerin in both larvae and adults of the grasshopper, Schistocerca americana. J Insect Physiol 2003, 49:1189-1197.

9. Kanost MR, Kawooya JK, Law JH, Ryan RO, Van Heusden MC, Ziegler R: Insect hemolymph proteins. Adv Insect Physiol 1990, 22:299-396.

10. Telfer WH, Kunkel JG: The function and evolution of insect storage hexamers. Annu Rev Entomol 1991, 36:205-228.

11. Martinez T, Wheeler DE: Identification of two storage hexamers in the ant, Camponotus festinatus: accumulation in adult queen-less workers. Insect Biochem Mol Biol 1993, 23:309-317.

12. Martinez T, Wheeler DE: Storage proteins in adult ants (Camponotus festinatus): roles in colony founding by queens and in larval rearing by workers. J Insect Physiol 1994, 40:723-729.

13. Johnston ML, Wheeler DE: The role of storage proteins in colonyfounding in termites. Insect Soc 2007, 54:383-387.

14. Zhou X, Oi FM, Scharf ME: Social exploitation of hexamerin, RNAi reveals a major caste-regulatory factor in termites. Proc Natl Acad Sci USA 2006, 103:4499-4504

15. Zhou X, Tarver MR, Bennett GW, Oi FM, Scharf ME: Two hexamerin genes from the termite Reticulitermes flavipes, sequence, expression, and proposed functions in caste regulation. Gene 2006, 376:47-58. 
16. Haydák MH: The food of the drone larvae. Ann Entomol Soc Am 1957 50:73-75

17. Jay SC: The development of honeybees in their cells. J Apic Res 1963, 2:117-134.

18. Winston ML: The biology of the honeybee Cambridge: Harvard University Press; 1987

19. Cunha AD, Nascimento AM, Guidugli KR, Simões ZL, Bitondi MM Molecular cloning and expression of a hexamerin cDNA from the honey bee, Apis mellifera. J Insect Physio/ 2005, 51:1135-1147.

20. Bitondi MM, Nascimento AM, Cunha AD, Guidugli KR, Nunes FM, Simões ZL: Characterization and expression of the Hex 110 gene encoding a glutamine-rich hexamerin in the honey bee, Apis mellifera. Arch Insect Biochem Physiol 2006, 63:57-72.

21. Martins JR, Nunes FMF, Simões ZLP, Bitondi MMG: A honeybee storage protein gene, hex 70a, expressed in developing gonads and nutritionally regulated in adult fat body. J Insect Physiol 2008 54:867-877

22. Rutherford K, Parkhill J, Crook J, Horsnell T, Rice P, Rajandream MA, Barrel B: Artemis: sequence visualization and annotation. Bioinformatics 2000, 16:944-945

23. Danty E, Arnold G, Burmester T, Huet JC, Huet D, Pernollet JC, Masson C: Identification and developmental profiles of hexamerins in antenna and hemolymph of the honeybee, Apis mellifera. Insect Biochem Mol Biol 1998, 28:387-397.

24. Telfer WH, Keim PS, Law JH: Arylphorin, a new protein from Hyalophora cecropia: comparisons with calliphorin and manducin. Insect Biochem 1983, 13:601-613.

25. Christianson AMK, King DL, Hatzivassiliou E, Casas JE, Hallenbeck PL, Nikodem VM, Mitsialis SA, Kafatos FC: DNA binding and heteromerization of the Drosophila transcription factor chorion factor 1/ultraspiracle. Proc Natl Acad Sci USA 1992, 89:11503-11507.

26. Rachinsky A, Strambi C, Strambi A, Hartfelder K: Caste and metamorphosis: hemolymph titers of juvenile hormone and ecdysteroids in last instar honeybee larvae. Gen Comp Endocrinol 1990, 79:31-38

27. Burmester T: Evolution and function of the insect hexamerins. Eur Entomol 1999, 96:213-225

28. Wheeler DE, Buck NA: Storage proteins in ants during development and colony founding. J Insect Physiol 1995, 41:885-894

29. Hunt JH, Buck NA, Wheeler DE: Storage proteins in vespid wasps: characterization, developmental pattern, and occurrence in adults. $J$ Insect Physiol 2003, 49:785-794.

30. Burmester T, Antoniewski C, Lepesant JA: Ecdysone-regulation of synthesis and processing of fat body protein 1, the larval serum protein receptor of Drosophila melanogaster. Eur J Biochem 1999, 262:49-55.

31. Beintema JJ, Stam WT, Hazes B, Smidt MP: Evolution of arthropod hemocyanins and insect storage proteins (hexamerins). Mol Biol Evol 1994, 11:493-503.

32. Yao TP, Segraves WA, Oro AE, McKeown M, Evans RM: Drosophila ultraspiracle modulates ecdysone receptor function via heterodimer formation. Cell 1992, 71:63-72.

33. Yao TP, Forman BM, Jiang Z, Cherbas L, Chen JD, McKeown M, Cherbas $P$, Evans RM: Functional ecdysone receptor is the product of EcR and Ultraspiracle genes. Nature 1993, 366:476-479.

34. Jones G, Jones D, Teal P, Sapa A, Wozniak M: The retinoid-X receptor ortholog, ultraspiracle, binds with nanomolar affinity to an endogenous morphogenetic ligand. FEBS J 2006, 273:4983-4996.

35. Burmester T: Origin an evolution of arthropod hemocyanins and related proteins. J Comp Physiol B 2002, 172:95-117.

36. Burmester T, Hankeln T: The respiratory proteins of insects. J Insect Physio/ 2007, 53:285-294.

37. Burmester T, Massey HC Jr, Zakharkin SO, Benes H: The Evolution of Hexamerins and the Phylogeny of Insects. J Mol Evol 1998, 47:93-108.

38. Hagner-Holler S, Pick C, Girgenrath S, Marden JH, Burmester T: Diversity of stonefly hexamerins and implication for the evolution of insect storage proteins. Insect Biochem Mol Biol 2007, 37:1064-1074.

39. Theißen G: Secret life of genes. Nature 2002, 415:741

40. Rembold $\mathrm{H}$ : Caste specific modulation of juvenile hormone titers in Apis mellifera. Insect Biochem 1987, 17:1003-1006.
41. Wirtz P, Beetsma J: Induction of caste differentiation in the honeybee (Apis mellifera L.) by juvenile hormone. Entomol Exp App/ 1972, 15:517-520

42. Rembold H, Czoppelt C, Rao PJ: Effect of juvenile hormone treatment on caste differentiation in the honeybee, Apis mellifera. J Insect Physiol 1974, 20:1193-1203

43. Zhou X, Tarver MR, Scharf ME: Hexamerin-based regulation of juvenile hormone-dependent gene expression underlies phenotypic plasticity in a social insect. Development 2007, 134:601-610.

44. Scharf ME, Buckspan CE, Grzymala TL, Zhou X: Regulation of polyphonic caste differentiation in the termite Reticulitermes flavipes by interaction of intrinsic and extrinsic factors. J Exp Biol 2007, 210:4390-4398

45. Tawfik Al, Kellner L, Hoffman KH, Lorenz MW: Purification, characterization and titre of the haemolymph juvenile hormone binding proteins from Schistocerca gragaria and Gryllus bimaculatus. J Insect Physiol 2006, 52:255-268.

46. Zalewska M, Kochman A, Estève JP, Lopez F, Chaoui K, Susini C, Ozyhar A, Kochman M: Juvenile hormone binding protein traffic - interaction with ATP synthase and lipid transfer proteins. Biochim Biophys Acta 2009, 1788:1695-1705

47. Chan QWT, Howes CG, Foster LJ: Quantitative comparison of caste differences in honeybee hemolymph. Mol Cell Proteomics 2006, 5:2252-2262.

48. Currie RW: The biology and behaviour of drones. Bee World 1987, 68:129-143.

49. Page RE Jr, Peng CYS: Aging and development in social insects with emphasis on the honey bee, Apis mellifera L. Exp Gerontol 2001, 36:695-711.

50. Capurro ML, Moreira-Ferro CK, Marinotti O, James AA, de Bianchi AG: Expression patterns of the larval and adult hexamerin genes of Musca domestica. Insect Mol Biol 2000, 9:169-177.

51. Haydák MH: Honey bee nutrition. Annu Rev Entomol 1970, 14:143-156.

52. Hrassnigg N, Crailsheim K: The influence of brood on the pollen consumption of worker bees (Apis mellifera L.). J Insect Physiol 1998, 44:393-404

53. Bitondi MMG, Simões ZLP: The relationship between level of pollen in the diet, vitellogenin, and juvenile hormone titres in Africanized Apis mellifera workers. J Apic Res 1996, 35:27-36.

54. Rutz W, Gerig L, Wille H, Lüscher M: The function of juvenile hormone in adult worker honeybees, Apis mellifera. J Insect Physiol 1976 22:1485-1491

55. Engels W, Kaatz H, Zillikens A, Simões ZLP, Trube A, Braun R, Dittrich F: Honeybee reproduction: vitellogenin and caste-specific regulation of fertility. In Advanced Invertebrates Reproduction Edited by: Hoshi M, Yamashita O. Elsevier, Oxford; 1990

56. Hartfelder K, Engels W: Social insect polymorphism: Hormonal regulation of plasticity in development and reproduction in the honeybee. Curr Top Dev Biol 1998, 40:45-77.

57. Piulachs MD, Guidugli KR, Barchuck AR, Cruz J, Simões ZLP, Bellés X: The vitellogenin CDNA of the honey bee, Apis mellifera: structural analysis and expression studies. Insect Biochem Mol Biol 2003, 33:459-465.

58. Crailsheim K, Schneider LHW, Hrassnigg N, Buhlmann G, Brosch U, Gmeinbauer R, Schoffmann B: Pollen consumption and utilization in worker honey bees (Apis mellifera carnica): dependence on individual age and function. J Insect Physiol 1992, 38:409-419.

59. Slansky JR, Scriber JM: Food consumption and utilization. In Comprehensive Insect Physiology Biochemistry and Pharmacology Edited by: Kerkut GA, Gilbert LI. New York: Oxford Pergamon Press; 1985.

60. Crailsheim K: Dependence os protein metabolism on age and season in the honeybee (Apis mellifera carnica Pollm). J Insect Physiol 1986 32:629-634

61. Guidugli KR, Nascimento AM, Amdam GV, Barchuk AR, Omholt S, Simões ZLP, Hartfelder K: Vitellogenin regulates hormonal dynamics in the worker caste of a eusocial insect. FEBS Letters 2005, 579:4961-4965

62. Hoffman DR: Hymenoptera Venom Allergens. Clin Rev Allergy Immunol 2006, 30:109-128.

63. McGraw LA, Gibson G, Clark AG, Wolfner MF: Genes regulated by mating, sperm, or seminal proteins in mated female Drosophila melanogaster. Curr Biol 2004, 14:1509-1514

64. Kocher SD, Richard FJ, Tarpy DR, Grozinger CM: Genomic analysis of postmating changes in the honey bee queen. BMC Genomics 2008, 9:232. 
65. Rembold H, Kremer JP, Ulrich GM: Characterization of postembryonic developmental stages of the female castes of the honeybee, Apis mellifera L. Apidologie 1980, 11:29-38.

66. Michelette ERF, Soares AEE: Characterization of preimaginal developmental stages in Africanized honeybee workers (Apis mellifera L.). Apidologie 1993, 24:431-440.

67. Tozetto SO, Bitondi MMG, Dallacqua RP, Simões ZLP: Protein profiles of testes, seminal vesicles and accessory glands of honeybee pupae and their relation to the ecdysteroid titer. Apidologie 2006, 38:1-11.

68. Elsik CG, Mackey AJ, Reese JT, Milshina NV, Roos DS, Weinstock GM: Creating a honey bee consensus gene set. Genome Biol 2007, 8:R13.

69. The Honey Bee Genome Sequencing Consortium: Insights into social insects from the genome of the honeybee Apis mellifera. Nature 2006, 443:919-920

70. Maclsaac KD, Fraenkel E: Practical strategies for discovering regulatory DNA sequences motifs. PLoS Comput Biol 2006, 2:e36.

71. Cristino ADS, Nunes FMF, Lobo CH, Bitondi MMG, Simões ZLP, Costa LDF, Lattorff HMG, Moritz RFA, Evans JD, Hartfelder K: Caste development and reproduction - a genome-wide analysis of hallmarks of insect eusociality. Insect Mol Biol 2006, 15:703-714.

72. Barchuk AR, Cristino AS, Kucharski R, Costa LF, Simões ZLP, Maleszka R: Molecular determinants of caste differentiation in the highly eusocial honeybee Apis mellifera. BMC Dev Biol 2007, 7:70.

73. Roth FP, Hughes JD, Estep PW, Church GM: Finding DNA regulatory motifs within unaligned noncoding sequences clustered by wholegenome mRNA quantification. Nature Biotechnol 1998, 16:939-945

74. Bailey TL, Elkan D: Unsupervised learning of multiple motifs in biopolymers using expectation maximization. Mach Learn 1995, 21:58-83.

75. Liu XS, Brutlag DL, Liu JS: An algorithm for finding protein-DNA binding sites with applications to chromatin-immunoprecipitation microarray experiments. Nature Biotechnol 2002, 20:835-839.

76. Hughes JD, Estep PW, Tavazole S, Church GM: Computational identification of cis-regulatory elements associated with groups of functionally related genes in Saccharomyces cervisiae. J Mol Biol 2000, 296:1205-1214.

77. Clarke ND, Granek JA: Rank order metrics for quantifying the association of sequence features with gene regulation. Bioinformatics 2003, 19:212-218

78. Harbison CT, Gordon DB, Lee TI, Rinaldi NJ, Macisaac KD, Danford TW, Hannett NM, Tagne JB, Reynolds DB, Yoo J, Jennings EG, Zeitlinger J, Pokholok DK, Kellis M, Rolfe PA, Takusagawa KT, Lander ES, Gifford DK, Fraenkel E, Young RA: Transcriptional regulatory code of a eukaryotic genome. Nature 2004, 431:99-104.

79. Wingender E, Chen X, HehI R, Karas H, Liebich I, Matys V, Meinhardt T, Prüb $M$, Reuter I, Schacherer F: TRANSFAC: an integrated system for gene expression regulation. Nucl Acids Res 2000, 28:316-319.

80. Chartrand G, Lesniak L: Graphs and Digraphs 3rd edition. Chapman and Hall/CRC; 1996.

81. Newman MEJ: Structure and function of complex networks. SIAM Review 2003, 45:167-256

82. Costa LF, Rodrigues FA, Cristino AS: Complex networks: The key to systems biology. Genet Mol Biol 2008, 31:591-601.

83. Eddy SR: Profile hidden Markov models. Bioinformatics 1998 , 14:755-763.

84. Bateman A, Coin L, Durbin R, Finn RD, Hollich V, Griffiths-Jones S, Khanna A, Marshall M, Moxon S, Sonnhammer EL, Studholme DJ, Yeasts C, Eddy SR: The Pfam protein families database. Nucleic Acid Res 2004 32:D138-141.

85. Edgar RC: MUSCLE: multiple sequence alignment with high accuracy and high throughput. Nucleic Acids Res 2004, 32:1792-1797.

86. Lourenço AP, Mackert A, Cristino AS, Simões ZLP: Validation of references genes for gene expression studies in the honey bee, Apis mellifera, by quantitative real-time RT-PCR. Apidologie 2008, 39:372-385.

87. Livak KJ, Schmittgen TD: Analysis of relative gene expression data using real-time quantitative PCR and the 2(-Delta Delta $C(T)$ ) method. Methods 2001, 25:402-408.

doi: $10.1186 / 1471-2199-11-23$

Cite this article as: Martins et al., The four hexamerin genes in the honey bee: structure, molecular evolution and function deduced from expression patterns in queens, workers and drones BMC Molecular Biology 2010, 11:23
Submit your next manuscript to BioMed Centra and take full advantage of:

- Convenient online submission

- Thorough peer review

- No space constraints or color figure charges

- Immediate publication on acceptance

- Inclusion in PubMed, CAS, Scopus and Google Scholar

- Research which is freely available for redistribution

Submit your manuscript at www.biomedcentral.com/submit
C) Biomed Central 


\title{
A Honey Bee Hexamerin, HEX 70a, Is Likely to Play an Intranuclear Role in Developing and Mature Ovarioles and Testioles
}

\author{
Juliana R. Martins ${ }^{1}$, Lucas Anhezini ${ }^{2}$, Rodrigo P. Dallacqua ${ }^{3}$, Zilá L. P. Simões ${ }^{3}$, Márcia M. G. Bitondi ${ }^{3 *}$ \\ 1 Departamento de Genética, Faculdade de Medicina de Ribeirão Preto, Universidade de São Paulo, Ribeirão Preto, São Paulo, Brasil, 2 Departamento de Biologia \\ Molecular e Celular e Bioagentes Patogênicos, Faculdade de Medicina de Ribeirão Preto, Universidade de São Paulo, Ribeirão Preto, São Paulo, Brasil, 3 Departamento de \\ Biologia, Faculdade de Filosofia, Ciências e Letras de Ribeirão Preto, Universidade de São Paulo, Ribeirão Preto, São Paulo, Brasil
}

\begin{abstract}
Insect hexamerins have long been known as storage proteins that are massively synthesized by the larval fat body and secreted into hemolymph. Following the larval-to-pupal molt, hexamerins are sequestered by the fat body via receptormediated endocytosis, broken up, and used as amino acid resources for metamorphosis. In the honey bee, the transcript and protein subunit of a hexamerin, HEX 70a, were also detected in ovaries and testes. Aiming to identify the subcellular localization of HEX 70a in the female and male gonads, we used a specific antibody in whole mount preparations of ovaries and testes for analysis by confocal laser-scanning microscopy. Intranuclear HEX 70a foci were evidenced in germ and somatic cells of ovarioles and testioles of pharate-adult workers and drones, suggesting a regulatory or structural role. Following injection of the thymidine analog EdU we observed co-labeling with HEX 70a in ovariole cell nuclei, inferring possible HEX 70a involvement in cell proliferation. Further support to this hypothesis came from an injection of anti-HEX 70a into newly ecdysed queen pupae where it had a negative effect on ovariole thickening. HEX 70a foci were also detected in ovarioles of egg laying queens, particularly in the nuclei of the highly polyploid nurse cells and in proliferating follicle cells. Additional roles for this storage protein are indicated by the detection of nuclear HEX 70a foci in post-meiotic spermatids and spermatozoa. Taken together, these results imply undescribed roles for HEX 70a in the developing gonads of the honey bee and raise the possibility that other hexamerins may also have tissue specific functions.
\end{abstract}

Citation: Martins JR, Anhezini L, Dallacqua RP, Simões ZLP, Bitondi MMG (2011) A Honey Bee Hexamerin, HEX 70a, Is Likely to Play an Intranuclear Role in Developing and Mature Ovarioles and Testioles. PLoS ONE 6(12): e29006. doi:10.1371/journal.pone.0029006

Editor: Peter K. Dearden, University of Otago, New Zealand

Received August 22, 2011; Accepted November 18, 2011; Published December 19, 2011

Copyright: (c) 2011 Martins et al. This is an open-access article distributed under the terms of the Creative Commons Attribution License, which permits unrestricted use, distribution, and reproduction in any medium, provided the original author and source are credited.

Funding: Financial support was provided by the Fundação de Amparo à Pesquisa do Estado de São Paulo (FAPESP grants 05/03926-5 and 10/16380-9), which also provided a fellowship to JRM (08/00541-3). The funders had no role in study design, data collection and analysis, decision to publish, or preparation of the manuscript.

Competing Interests: The authors have declared that no competing interests exist.

*E-mail: mmgbit@usp.br

\section{Introduction}

The larvae of holometabolous insects accumulate a large quantity of proteins, carbohydrates and lipids which serve as energy and structural compounds for sustaining metamorphosis up to the adult stage [1]. The most abundant proteins in larval hemolymph are the hexamerins, also known as larval serum proteins, or simply, as storage proteins. Hexamerins are high molecular mass molecules composed, by definition, of six subunits, which can be either homo- or heteromers. Evolutionarily they are derived from hemocyanins, but in contrast to the ancestral molecule, they have lost the capacity of binding copper ions for oxygen transport, and mainly have a role as storage proteins [2].

Hexamerins are massively synthesized by the larval fat body and secreted in hemolymph. Following cessation of larval feeding in preparation to the larval-to-pupal molt, these proteins are sequestered from hemolymph by the fat body cells, via endocytosis mediated by membrane receptors [3], and stored in the cytoplasm in the form of granules [4]. As such, they can be processed and used as amino acid source for development completion. In line with the idea that the sole function of most hexamerins is to act as amino acid reserves when feeding is no longer occurring, as during the pupal and pharate-adult stages, Roberts and Brock (1981) [5] considered that hexamerins are the essential proteins for metamorphosis, as vitellogenins are to embryogenesis.

The importance of hexamerins as amino acid storage proteins during metamorphosis was initially demonstrated by injecting larvae of the dipteran Calliphora vicina with $\left[{ }^{14} \mathrm{C}\right]$-phenylalanine that was metabolically incorporated into hexamerin molecules (then called calliphorins), and following the fate of the radioactive carbon isotope. Using this strategy, Levenbook and Bauer (1984) [6] verified that most of the soluble proteins from practically all tissues of the developing pharate-adults became labeled. In a similar experiment, labeled proteins were recorded not only in adult somatic tissues (integument, thoracic muscle), but also in the egg (chorion, yolk) of Actias luna, a moth that produces its eggs during pharate adult development [7]. A correlation between egg production and depletion of the larval reserve of hexamerins was established in adult lepidopterans unable to eat (without mouth parts) or that feed basically on nectar, a poor protein diet [7-10] despite containing amino acids of supplemental nutritional value [11]. There is also circumstantial evidence that amino acids held in hexamerins are used for provisioning eggs of non-lepidopteran species, such as, the mosquito Aedes atropalpus, which produces the 
first batch of eggs without a feeding [12,13], the cockroach Blaberus discoidalis [14], the house fly Musca domestica [15], and the grasshopper Schistocerca americana [16]. The high level of hexamerins stored by Camponotus festinatus queen ants and by certain species of termites was also related to the production of the first batch of brood without access to food during colony founding [17-19]. Together, these results indicate that hexamerin residues are recycled to make other proteins needed for tissues reconstruction during metamorphosis and, in some insect species, for egg production. Thus, after hexamerin breakdown in the fat body, the released amino acid residues are reutilized and incorporated into new proteins, although there is also evidence of incorporation of hexamerins into tissues after partial degradation [20] or even without degradation $[4,21]$.

In general, hexamerins disappear from hemolymph within a few days after adult eclosion. Nevertheless, in some insect species they may persist in hemolymph up to the adult stage [14,22]. There is also evidence of synthesis reinduction and even de novo synthesis in adults, although at a lower rate $[13,23]$.

A special class of hexamerins, the arylphorins, has received special attention in view of their high content of aromatic amino acids. In fact, arylphorins have long been presumed to be a source of aromatic amino acids for exoskeleton sclerotization in lepidopterans [7,24-27]. Hexamerins from Locusta migratoria [28,29] and Melanoplus sanguinipes [30] also play a role as hemolymph juvenile hormone transporters, and the Larval Hemolymph Protein-1 of Calliphora vicina has been confirmed as a low affinity carrier protein for ecdysteroids [4]. Recently, Zalewska et al. (2009) [31] demonstrated that hexamerins interact with other proteins (juvenile hormone binding protein and apolipophorin) in a multiprotein complex engaged in sequestration and transport of juvenile hormone, thus inferring the involvement of hexamerins in regulating juvenile hormone levels and action, even when they do not directly bind to the hormone.

Based on the purported ability of binding and controlling juvenile hormone levels, hexamerins have been linked to important facets of social insect life histories. In the termite Reticulitermes flavipes, the role of hexamerins has been associated to the regulation of the juvenile hormone-dependent soldier caste phenotype [32-35]. Also in honey bee larval development, the inverse relationship between the levels of hexamerin transcripts in the fat body and the juvenile hormone titer suggests that hexamerins may act as players in the juvenile hormone-dependent differentiation of the bipotent female larva towards a queen or a worker phenotype [36]. In the social wasp Polistes metricus, one hexamerin may be involved in caste-specific behaviors and in the regulation of diapause, which is also conditional on a low titer of juvenile hormone [37].

Except for the termite $R$. flavipes, most of the above mentioned considerations on the roles of hexamerins in social insect life histories are based on correlational or other circumstantial evidence, still requiring experimental confirmation and in-depth analysis at the cellular level.

In the highly eusocial honey bee, Ryan et al. (1984) [38] were the first to characterize a hexamerin subunit in the range of 75$80 \mathrm{kDa}$. Later, four hexamerin subunits (including the one previously described by Ryan [38]) were distinguished in honey bee hemolymph samples by SDS-PAGE and N-terminal sequencing [39]. Since three of these subunits presented molecular mass in the $70 \mathrm{kDa}$ range, they were named HEX 70a, HEX 70b, and HEX 70c. The other subunit migrated at a rate consistent with a higher molecular mass and was named HEX 110. Studies undertaken in our laboratory led to the characterization of the full-length cDNAs encoding the four honey bee hexamerin subunits. These studies enabled the characterization of the structure of these genes and the prospection of overrepresented sequence motifs indicative of mutual co-regulation in the respective upstream control regions. It was also investigated the evolutionary relationship between the honey bee hexamerins and homologous proteins from other insect species. Furthermore, we characterized the expression patterns of the four hexamerin genes in the fat body and gonads of developing and adult workers, queens and drones, as well as the hormonal- and nutritionaldependent expression of these genes [23,36,40,41].

A honey bee arylphorin, HEX 70a, is the focus of the current work. Through RT-PCR (semiquantitative and quantitative) and western blot analyses using a specific antibody we had previously demonstrated that, besides being strongly expressed in the larval fat body, the HEX 70a transcript and protein subunit were also present in the male and female gonads [23]. In the search for a role of this hexamerin in ovaries and testes we designed experiments for its immunofluorescence detection by confocal laser-scanning microscopy. In parallel, a nucleoside analog of thymidine coupled to a dye was used for prospection of dividing cells in developing ovaries. To highlight structural aspects of the gonads at the developmental stages here approached we used rhodamine-phalloidin labeling for F-actin and DAPI-labeling for cell nuclei, in addition to conventional histology.

\section{Results}

\section{HEX 70a detection in ovarian cell nuclei in pharate-adult workers}

Ovary sections of a pharate-adult worker show the basic structure of an ovariole stained with methylene blue and basic fuchsin (Figure 1A), the actin array visualized through rhodamine/ phalloidin staining (Figures 1B, C), and foci of HEX 70a immunodetected with anti-HEX70a/Cy3 (Figures E, F). DAPI was used to highlight ovarian cell nuclei and to make ovariole visualization easier (Figures 1B, C, D, F). At this initial stage of pharate-adult development ( $\sim 1$ day after pupal ecdysis), each ovariole consists of a distal terminal filament (not shown) and a proximal germarium. In the germarium the germline cells, or cystocytes, are beginning to be arranged in rosette-like structures (circle in Figure 1A). Each rosette is a cystocyte clone derived from a single cystoblast (oogonium) and will give rise to a single oocyte and the accompanying trophocytes, or nurse cells. To better visualize the structure of the ovariole at this developmental stage (early pharate-adult) we used rhodamine/phalloidin for detection of F-actin, and DAPI to stain the ovarian cell nuclei. In the upper region of the germarium (upper part of Figure 1B) we could visualize the dense actin complex typical of the polyfusomal region in the center of each cystocyte rosette (arrowheads in Figure 1B). In the lower region of the germarium (lower part of Figure 1B and Figure $1 \mathrm{C}$ ) the polyfusomes were converted into ring canals (arrows in Figures 1B, C) that allow communication among the germline cells, i.e., among the cell destined to be the oocyte and its associated nurse cells. Ovarioles characterized by such structural arrangements, as detailed in Figures 1A-C, were prepared for HEX 70a detection with anti-HEX 70a/Cy3. Figure 1D shows the upper region of the germarium of an ovariole stained with DAPI. Figure 1E illustrates the same ovariole region where foci of HEX 70 a can be seen (merged image is shown in Figure 1F). The insert in Figure $1 \mathrm{~F}$ represents a control ovariole incubated with preimmune serum and stained with DAPI and Cy3. Comparison among Figures 1D-F revels that HEX 70a is localized in the nuclei of the germline cells (cystocytes), in close association with chromatin (arrowheads in Figures 1D-F). Presumptive follicle 

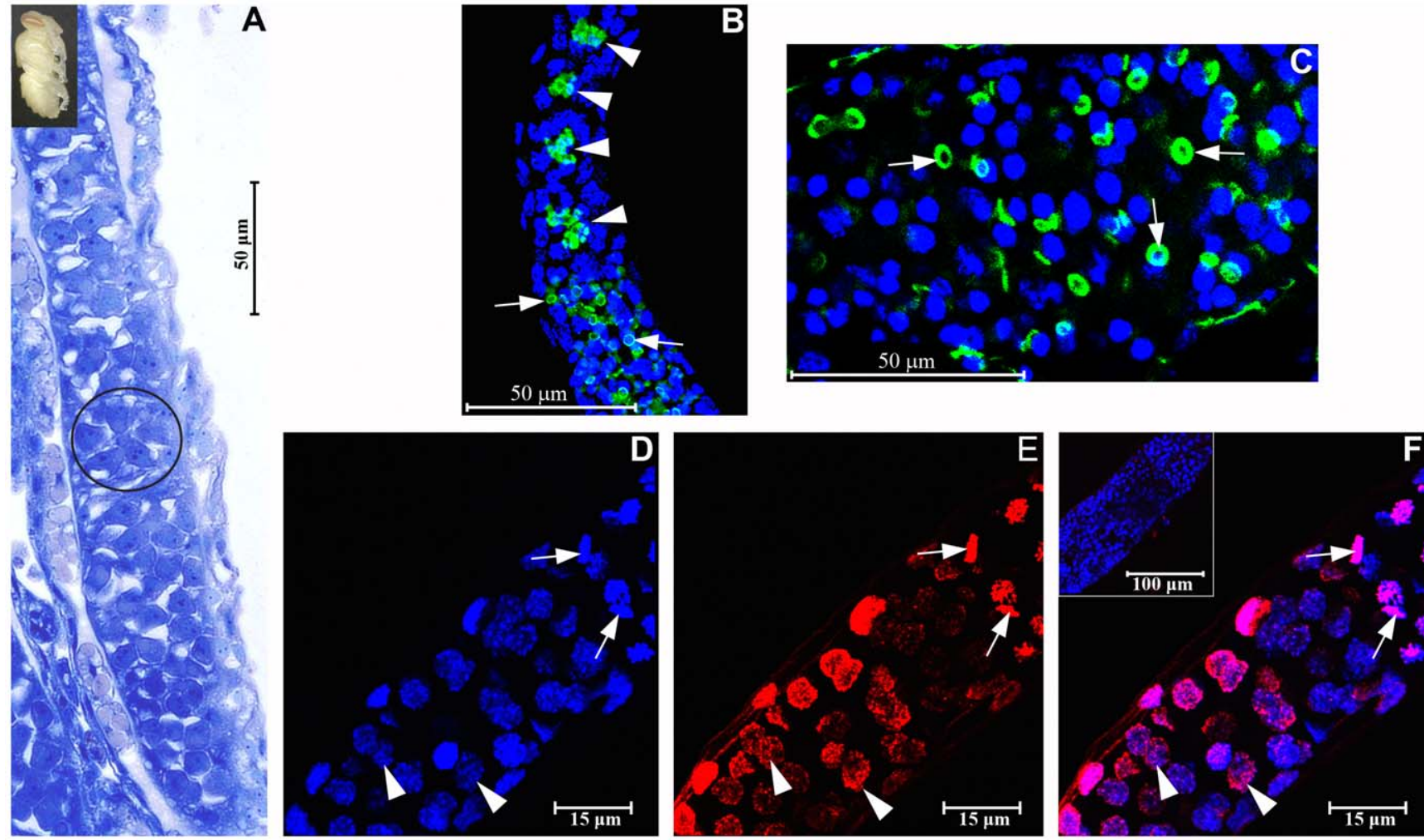

Figure 1. Detection of HEX 70a in ovarioles of workers at the beginning of the pharate-adult development $(\sim 1$ day after pupal ecdysis) (the developmental stage is illustrated at the upper left corner of the figure). (A) Light microscopy of ovarioles (covered by their respective peritoneal sheath) stained with methylene blue/basic fuchsin. Only the germarium is focused in this figure (the most anterior region of the ovariole, or terminal filament, is not shown). A rosette formed by germline cells (oocyte and nurse cell precursors) is distinguishable (circle) in the germarium. (B, C) Confocal microscopy image of rhodamine/phalloidin labeled F-actin (green) and DAPI-labeled cell nuclei (blue) showing aspects of the structure of the ovarioles (peritoneal sheath removed) at the time they were used for HEX 70A detection. The actin-rich polyfusomes (arrowheads in B) are seen in the center of the cystocyte rosettes in the upper region of the germarium. Ring canals derived from polyfusomes (arrows in B and C) are apparent in the lower region of the germarium shown in B and in higher magnification in C. (D) Confocal microscopy of an ovariole (upper portion of the germarium) stained with DAPI. (E) The same ovariole showing foci of HEX 70a detected with anti-HEX 70a/Cy3 (red). (F) The merged D and $\mathrm{E}$ images. The insert in F shows a "control" ovariole (upper portion of the germarium) incubated with the pre-immune serum and subsequently stained with Cy3/DAPI. Arrowheads in D-F show nuclei of germline cells. Arrows in D-F point to nuclei of follicle cell precursors. In all figures, the upper portion of the germarium is oriented upward. doi:10.1371/journal.pone.0029006.g001

cells (somatic cells) are not clearly evident at this stage, but were tentatively indicated by arrows in Figures 1D-F. Like the germline cell nuclei, the somatic cell nuclei show HEX 70a foci.

\section{Colocalization of EdU and HEX 70a in the ovarian cell nuclei of pharate-adult workers}

EdU is a nucleoside analog of thymidine that incorporates into DNA during the S-phase of the cell cycle, thus allowing the detection of DNA replication for cell division when coupled to a dye (Alexa Fluor 594). EdU was injected in early pharate adults ( $\sim 1$ day after pupal ecdysis). The ovaries were dissected after $24 \mathrm{~h}$ and prepared for confocal microscopy. Figures 2A-D show confocal images of one of these ovaries. In Figure 2A the DAPIstaining highlighted the cell nuclei in the base of the ovary and in its constituent ovarioles. Only the germarium region is shown in each ovariole. Figure 2B revealed intranuclear HEX 70a/Cy3 foci spread throughout the ovary. By comparing Figures 2A and 2B we identified regions of DAPI-stained nuclei in the ovarioles (germarium) without HEX 70a/Cy3 foci. Therefore, HEX 70a is not present in every ovarian nuclei. Figure $2 \mathrm{C}$ revealed EdU incorporation in S-phase nuclei. In a comparative analysis, the Figures 2B, C and the merged image seen in Figure 2D revealed that the nuclei labeled with EdU/Alexa Fluor also show HEX 70a/Cy3 labels, suggesting that HEX 70a may be somehow involved in the S-phase events leading to cell proliferation in ovarioles. However, HEX 70a has a nuclear localization even in cells outside the S-phase, since the overlap between HEX 70a/ Cy3 and EdU/Alexa Fluor labels is not complete: for example, the nuclei showing HEX 70a immunofluorescence at the right margin of the ovary in Figure 2B do not show EdU fluorescence (Figures 2C, D).

Expression of HEX 70a in ovarioles of egg laying queens HEX 70a foci were also detected in ovarioles dissected from adult queens. Figure $3 \mathrm{~A}$ shows a schematic representation of an ovariole of an egg-laying queen. The ovariole consists of a narrow distal region, the terminal filament, an intermediate region, or germarium, and a proximal region, the vitellarium. The terminal filament contains typical coin-shaped somatic cells and putative germline stem cells [42]. Cystocyte clusters are observed in the upper region of the germarium, and in the lower region there are growing oocytes associated with the polyploid nurse cells. In the upper region of the vitellarium (Figure 3A), nurse cell and oocyte chambers forming the pre-vitellogenic follicles are visible. The 

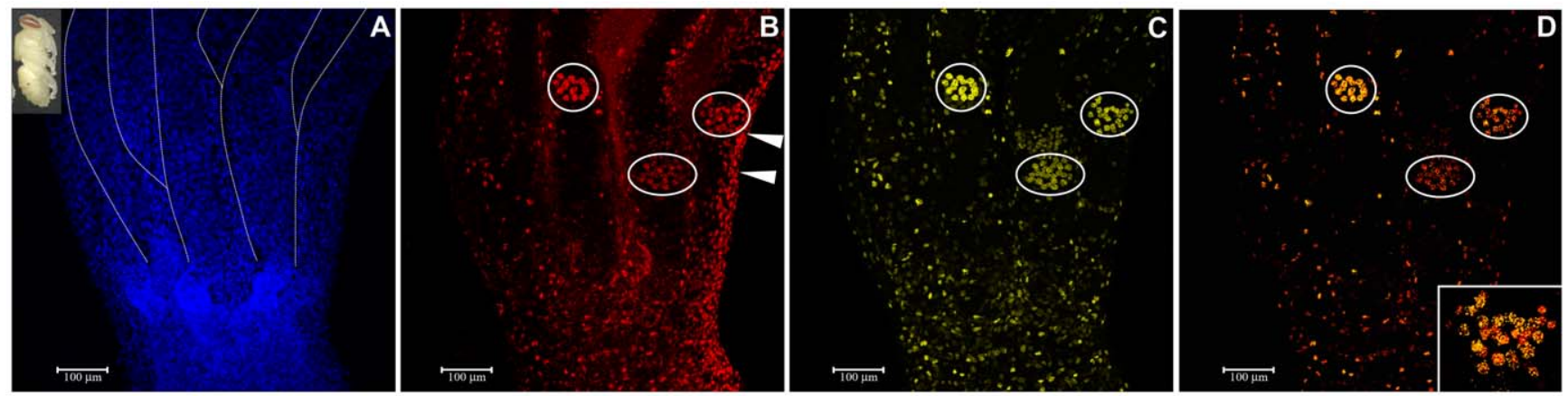

Figure 2. Colocalization of anti-HEX $70 \mathrm{a} / \mathrm{Cy3}$ and EdU/Alexa Fluor in the ovary of a pharate-adult worker ( $\sim 2$ days after pupal ecdysis: seen at the upper left corner of the figure). (A) DAPI-stained ovarian cell nuclei (shown in blue). For clarity, the ovarioles are delineated by dashed lines above the basal portion of the ovary. Only the germarium region is seen in each ovariole. (B) HEX 70a foci detected with anti-HEX 70a/Cy3 (red). (C) EdU/Alexa Fluor foci in S-phase ovarian nuclei (yellow). (D) Merged B and C images. Circles in B-D emphasize groups of cystocytes (in the germarium region) showing double labeling (anti-HEX 70a/Cy3 and EdU/Alexa Fluor). The group of cystocytes encircled at the most right position in $D$ is shown in higher magnification in the insert. Cell nuclei on the right margin of the ovary in B (arrowheads) show $\mathrm{HEX} 70 \mathrm{a} / \mathrm{Cy} 3 \mathrm{but}$ not EdU/Alexa Fluor labels.

doi:10.1371/journal.pone.0029006.g002

lower region of vitellarium is the largest region of the ovariole (shown in Figure 3B) and consists of a sequence of growing oocytes involved by a layer of follicle cells (arrowheads) interspersed with nurse cell chambers (arrows). In this region, the oocyte reaches its maximum size, the nurse cells collapse, the chorion is formed and the egg is finally released into the oviduct.

Figures $3 \mathrm{C}-\mathrm{E}$ shows the lower region of the terminal filament. In this region, HEX 70a is strongly associated with cell nuclei, but foci of HEX 70a in the cytoplasm of filament cells were also noticed (Figure 3D, E, arrows). HEX 70a was also localized in the nuclei of the nurse cells (Figures $3 \mathrm{~F}-\mathrm{H}$ ), as well as in the nuclei of the somatic follicle cells (Figures 3I-K), which cover the oocyte. In both cell types, HEX 70a has exclusively an intranuclear localization, but with a very distinct pattern of foci size and distribution. HEX 70a foci are small and scattered all over the nuclei of the polyploid nurse cells and are larger and concentrated in defined nuclear areas in the proliferating follicle cells.

\section{Effect of anti-HEX 70a injection on ovariole width and cuticle sclerotization}

To strengthen the hypothesis that HEX 70a is involved in ovariole cell proliferation we injected 24 h-queen pupae with antiHEX 70a (diluted in $0.9 \% \mathrm{NaCl}$ ) and measured the width of the ovarioles soon after the adult ecdysis, under the expectation that the specific antibody would reduce HEX 70a activity and, thus, result in smaller ovarioles. Figure $4 \mathrm{~A}$ shows that the antibody injection significantly hampered ovariole growth $(p=0.002)$ in comparison with control queens injected with the vehicle only.

In parallel, 24 h-worker pupae were also injected with antiHEX 70a and the effect of this antibody on the hemolymph HEX $70 \mathrm{a}$ levels was examined. Western blots revealed a reduction of $54 \%$ (estimated by densitometric assessment in arbitrary units obtained from HEX 70a bands normalized to the $\sim 200 \mathrm{kDa}$ lipophorin loading control) in the levels of HEX 70a $4 \mathrm{~h}$ after injection of the antibody, followed by recovery to normal levels within $72 \mathrm{~h}$ (Figure 4B). Given that HEX 70a is an arylphorin, and as such, it may represent a source of aromatic amino acids for cuticle formation, we also checked the progress of pigmentation and sclerotization in anti-HEX 70a-injected workers, comparing them to two control groups, injected with mouse IgG or only with the antibody vehicle. Anti-HEX 70a injection produced a drastic effect on cuticle formation. This effect was more evident in the cuticle of the hind legs that were not fully pigmented and sclerotized. In anti-HEX 70a-treated bees, the hind leg cuticle is clearer and softer than in the control groups (Figure 4C). Taken together, the data shown in Figure 4 are consistent with the proposed participation of HEX 70a in ovariole cell proliferation, confirmed that the antibody is effective in reducing HEX 70a levels, and furthermore, confirmed that HEX 70a is a genuine arylphorin with a role in cuticle formation (in addition to being a nuclear protein in the gonads).

\section{Expression of HEX 70a in the testes}

HEX 70a was also detected in the germ and somatic cells of developing testes. Figure 5A shows a cross section of the upper portion of a testiole dissected from a drone pupa ( 1 day after pupal ecdysis). In this region we could observe cysts, i.e., groups of germ cells (cystocytes or spermatogonia: arrows in Figure 5A) housed within a somatic cell envelope (somatic cell nuclei pointed by arrowheads in Figure 5A). Confocal microscopy on rhodamine/ phalloidin-labeled F-actin (green) and DAPI-labeled cell nuclei (blue) (Figure 5B) highlighted the structure of this region of the testiole. F-actin is an abundant component of the somatic cell cytoplasm, and is also present in the ring canals (asterisks in Figure 5B) that enable mutual communication for the germ cells. Comparison of Figures 5C-E revealed foci of HEX 70a mainly in the nuclei of the germ cells (thick arrows in Figure 5E) and somatic cells (arrowheads in Figure 5E), but also dispersed in the cytoplasm of the germ cells (thin arrows in Figure 5E). The small volume of cytoplasm in the somatic cells impairs the accuracy in identifying possible cytoplasmic HEX 70a foci in the confocal images.

Sections of the lower region of testioles dissected from drones at an intermediate phase of the pharate adult development $(\sim 6$ days after pupal ecdysis) showed syncytial clusters of elongating spermatids (Figures 6A, G, arrows). Actin cones were seen assembled around the tip of the spermatid nuclei (Figures 6B, D, arrows). Figure 6E shows DAPI-stained nuclei of spermatids in syncytial clusters (arrows) and of somatic cells (arrowheads). In Figure 6F, which is a preparation stained with anti-HEX 70a/ Cy3, and in the merged image (Figure 6G) we could verify that HEX 70a was strongly localized to the posterior extremity of the spermatid nuclei (Figures 6F, G inserts), as well as in the nuclei of individualized spermatozoa (arrows in Figures 6F, G) and somatic cells (arrowheads in Figures 6F, G). 

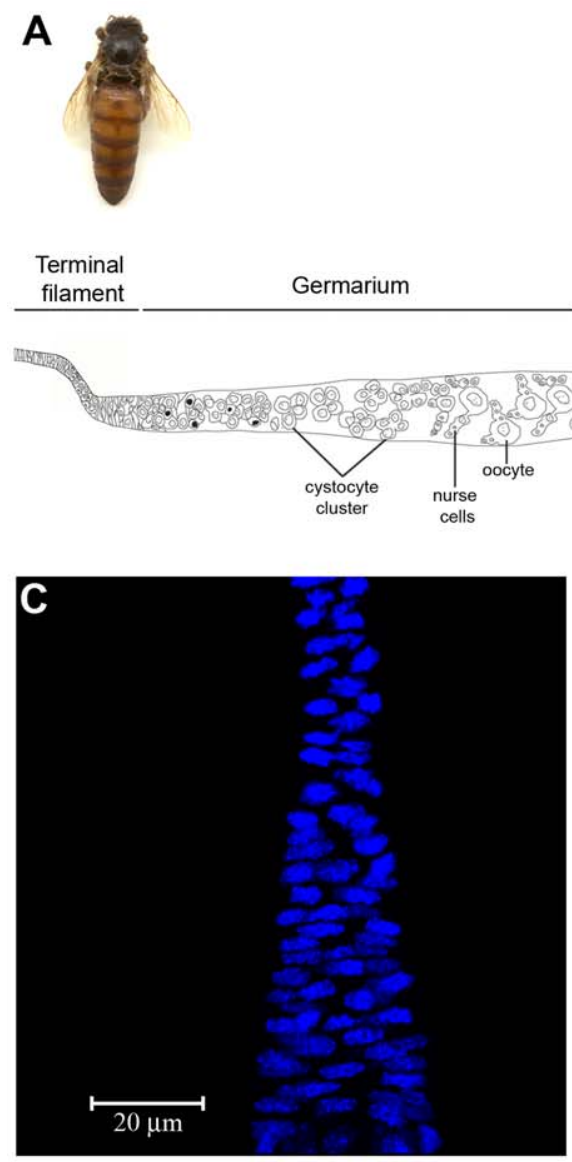

Vitellarium (Previtellogenic follicles)
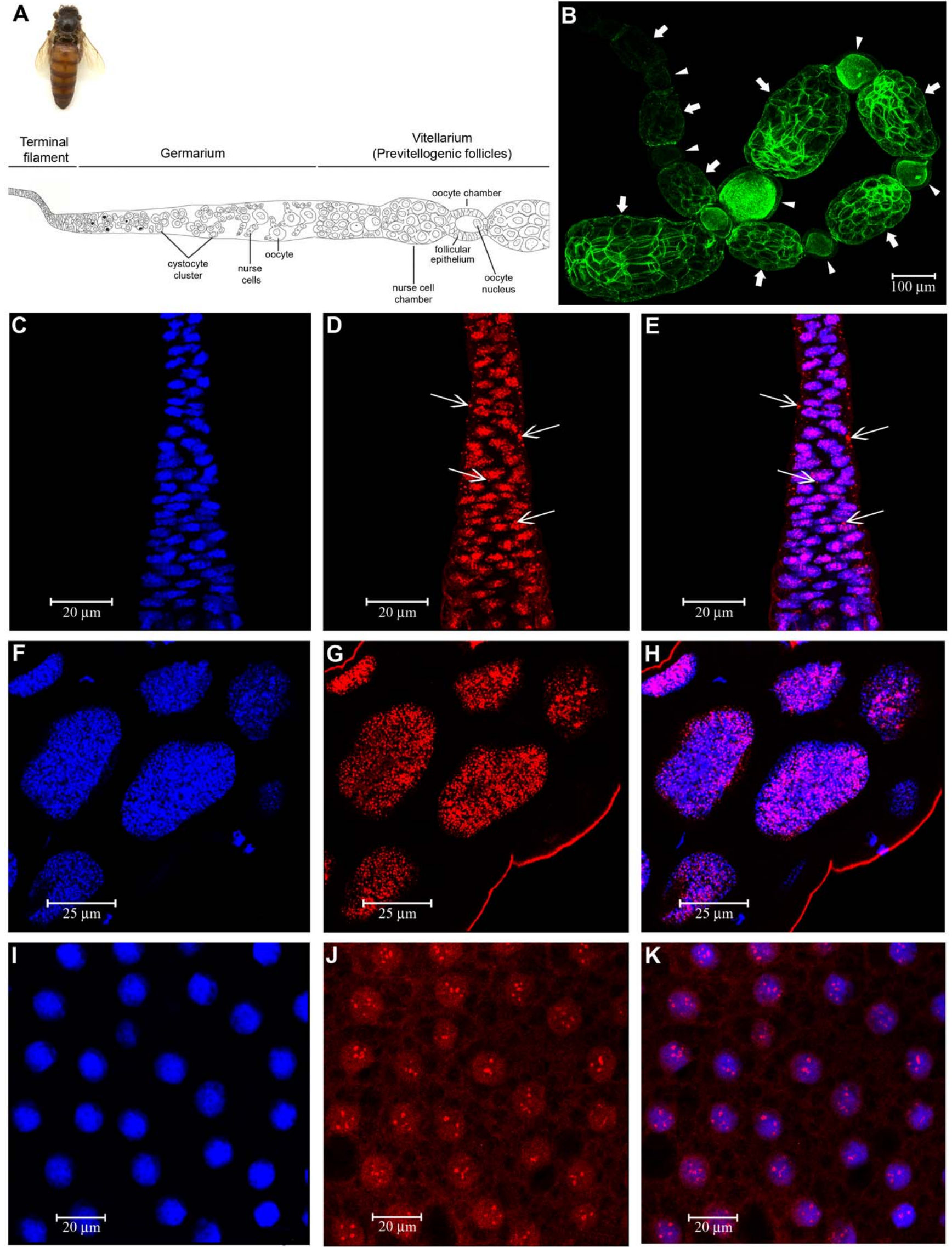
Figure 3. Immunolocalization of HEX 70a in the queen ovariole. (A) Schematic representation of an ovariole of an egg laying queen (seen at the upper left corner): only the terminal filament, the germarium and early follicles initiating previtellogenic growth in the upper region of the vitellarium are shown in A. Confocal microscopy images: (B) Part of an ovariole showing the middle and lower regions of the vitellarium labeled with rhodamin/phalloidin (green) to highlight F-actin. The arrows and arrowheads show developing nurse cell- and oocyte- chambers, respectively. (C-E) the terminal filament (the lower region is oriented downward) shows HEX 70a foci in the nuclei (D,E) and in cytoplasm (arrows in D, E). (F-H) Nurse cell nuclei in the nurse cell chamber (lower region of the vitellarium as indicated by arrows in B). (I-K) Follicle cell nuclei covering an oocyte at the lower region of the vitellarium (as indicated by arrowheads in B). (C, F, I) DAPI-stained cell nuclei (blue); (D, G, J) anti-HEX 70a/Cy3-staining for HEX 70a detection (red) and $(\mathbf{E}, \mathbf{H}, \mathbf{K})$ merged images.

doi:10.1371/journal.pone.0029006.g003

\section{Discussion}

HEX 70a in oogenesis and spermatogenesis of the honey bee

Herein we show that the honey bee HEX 70a is localized in the nuclei of ovarian and testis cells, thus implying in a yet undescribed role for this hexamerin. In its native structure, HEX 70a is an oligomer (data not shown). Similar to other proteins, HEX 70a may be acting in the nucleus in the monomeric form, as recently reported for royalactin, a $57 \mathrm{kDa}$ monomer that functions as a caste determining factor in the honey bee. Royalactin forms the oligomere MRJP1, a member of the Major Royal Jelly Protein family, which is present not only in royal jelly secreted by the worker hypopharingeal glands, but also in hemolymph and other tissues of the honey bee [43].

HEX 70a fulfills all the criteria established for classification as a storage hexamerin. It has the three canonical hemocyanin domains (N: PF03722.5, M: PF00372.10 and C: PF03723.5 Pfam database, [44]), which are typical of all hexamerins. It is massively synthesized by the fat body during the larval feeding stage and abundantly stored into larval hemolymph, remains in high quantity in pupal and early pharate-adult hemolymph, and subsequently becomes less abundant [23,39]. This feature is in conformity with the role in providing amino acids for pupal and pharate adult development, just like the other hexamerins. Furthermore, it contains a high proportion $(18.2 \%)$ of aromatic amino acids, which makes it a member of a subclass of hexamerins, the arylphorins. HEX 70a is likely used for adult cuticle construction. As demonstrated herein, the inactivation of HEX 70a in vivo by injecting anti-HEX 70a into worker pupae visibly hampered the process of adult cuticle formation. Interestingly, the experimental decrease in HEX 70a in hemolymph provoked through antibody-injection was sufficient to affect cuticle formation, despite the presence of another arylphorin, HEX 70b, in hemolymph at this stage [40]. This indicates that HEX 70a, or the amino acids derived from its hydrolysis, have essential participation in cuticle formation.

Previous experimental evidence in our laboratory had already indicated that HEX 70a is a multifunctional protein. By means of semiquantitative and quantitative RT-PCR and Western blot analysis using anti-HEX 70a, we could show that the fat body is not the only site of HEX 70a production, as the transcript and the corresponding protein subunit were also detected in developing gonads of workers, queens and drones, suggesting roles in ovary

B
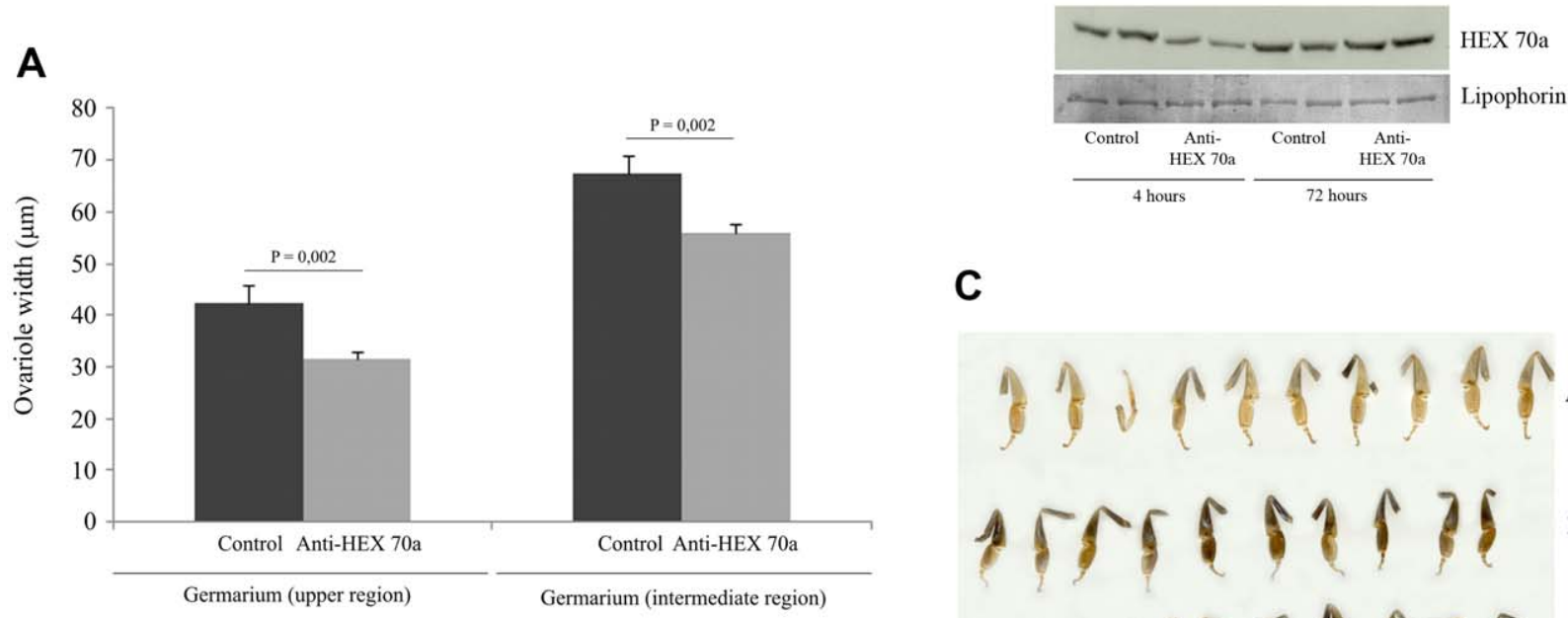

C

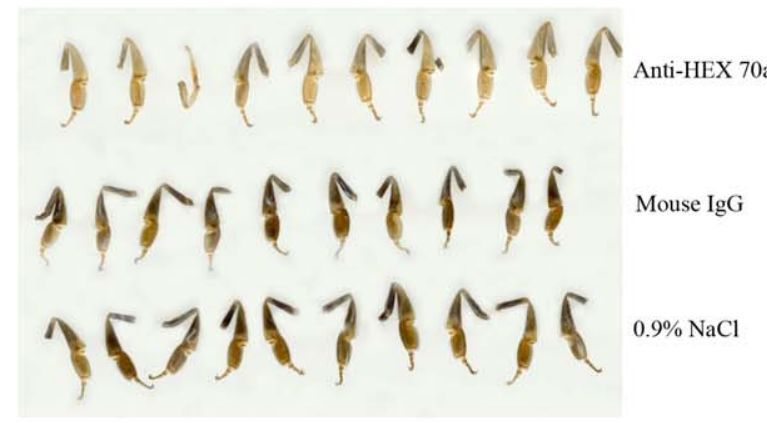

Figure 4. Effect of HEX 70a depletion on queen ovary growth and worker cuticle formation. (A) Width of the ovarioles of queens injected with anti-HEX 70a in $0.9 \% \mathrm{NaCl}$ or saline vehicle only. Measurements were made in two regions of the germarium of 120 ovarioles, 60 of them dissected from 3 anti-HEX 70a injected queens (20 ovarioles per queen), and 60 from 3 control queens. Measurements obtained from bees injected with the antibody, or the antibody vehicle only, were compared using Two-Way ANOVA and the post-hoc Holm-Sidak multiple comparison test (Jandel SigmaStat 3.1 software, Jandel Corporation, San Rafael, CA, USA). (B) Western blot levels of HEX 70a in the hemolymph samples of workers at 4 and $72 \mathrm{~h}$ after injection with anti-HEX 70a or saline vehicle only (control). The levels of the $\sim 200 \mathrm{kDa}$ lipophorin in the same samples were used as loading control. (C) Hind legs of workers injected with anti-HEX 70a in $0.9 \% \mathrm{NaCl}$, in comparison to workers injected with mouse lgG in $0,9 \% \mathrm{NaCl}$, or those of the $0.9 \% \mathrm{NaCl}$ injected group.

doi:10.1371/journal.pone.0029006.g004 


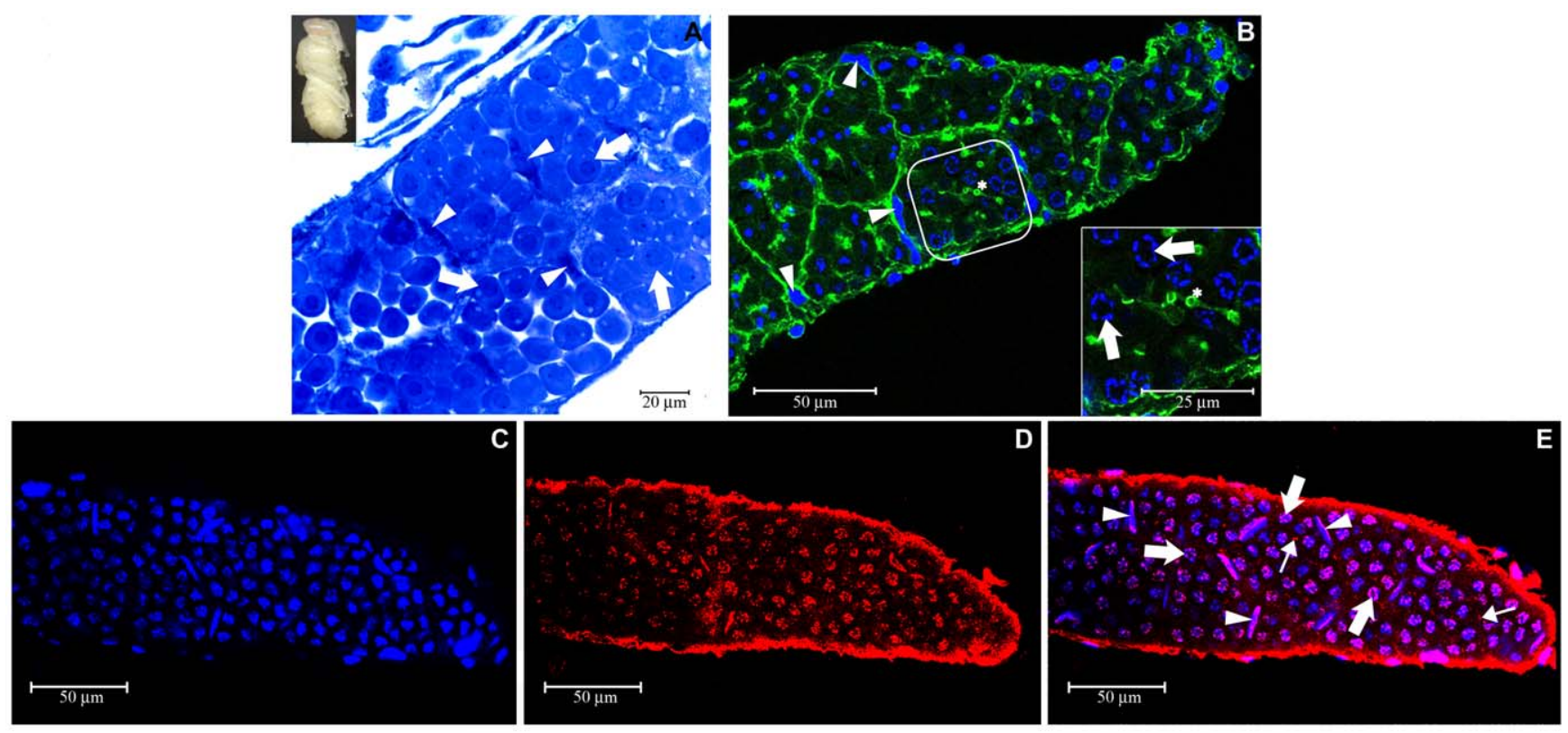

Figure 5. Immunolocalization of HEX 70a in the testioles of drone pupae (1 day after pupal ecdysis; developmental stage shown at the upper left corner). (A) Light microscopy section of a testiole stained with methylene blue/basic fuchsin showing a region containing groups of cystocytes (spermatogonia) (arrows) involved by somatic cells (somatic cell nuclei pointed by arrowheads). (B) Confocal microscopy image showing rhodamine/phalloidin labeled F-actin (green) and DAPI-labeled cell nuclei (blue); somatic cell nuclei are pointed by arrowheads; insert shows a magnified image of a cyst containing cystocytes (cystocyte nuclei pointed by arrows) and ring canals (asterisks). (C-E) Confocal microscopy images of a testiole from a drone taken at the same developmental phase, showing (C) DAPI-stained cell nuclei, (D) foci of HEX 70a detected with anti-HEX 70a/ Cy3 (red), and (E) the merged C and D images. In Figure 1E the thick arrows show germ cell nuclei, the thin arrows show HEX 70a foci in the cytoplasm and the arrowheads show somatic cell nuclei.

doi:10.1371/journal.pone.0029006.g005

differentiation and testes maturation. HEX 70a transcripts and protein subunits were also detected in the ovaries of adult queens (but not in the worker bee hypopharyngeal glands) [23].

Following up on this question, the immunodetection of HEX $70 \mathrm{a}$ in the gonads now evidenced an association of this protein with nuclei of germline and somatic cells. Such localization was completely unexpected for a storage protein, implying regulatory or structural roles in the nuclei. The nuclear colocalization of HEX 70a with the S-phase marker EdU furthermore indicated that HEX 70a may play a role in DNA replication for cell proliferation or polyploidization. However, there are also ovariole cell nuclei showing HEX 70a immunofluorescence, but not EdU fluorescence (the reverse was not observed). This does not exclude a possible HEX 70a role in cell proliferation, but may indicate that HEX 70a does not have an exclusive role in the S-phase of the cell cycle, or that the stability of the protein within the nuclei is not restricted to the S-phase.

The hypothesis that HEX 70a is involved in cell proliferation received support from experiments where anti-HEX 70a antibody was injected into queen pupae, revealing negative effects on ovariole enlargement, which likely occurs via cell proliferation. Consistent with this hypothesis, HEX 70a was localized in the nuclei of the cystocytes in the ovaries of early pharate-adult workers. Cystocytes are mitotically active, as shown here by EdU labeling, and through BrdU (5-bromo-2'deoxy-uridine) labeling [42]. Each cystocyte proliferates to form a clone of about 48 or more cells $[45,46]$ which is arranged as a rosette and contains a germline-specific organelle, the polyfusome [47]. Actin was shown to be a prominent fusome marker in the center of the rosettes $[48,49]$. Only later in development will one cystocyte in each rosette enter meiosis and begin to grow and then become morphologically distinguishable from the nurse cell-destined cystocytes. As the oocyte differentiates, the rosettes are gradually transformed into initial follicles, with the fusomes being converted into the ring canals that connect the developing oocyte with the nurse cells, and the nurse cells with each other. Each growing oocyte/nurse cell cluster becomes surrounded by somatic follicle cells and will be partitioned into an egg chamber, where oogenesis and vitellogenesis proceed, and a trophic chamber (or nurse cell chamber) $[42,46,50]$. Whilst this is the common pattern in queens, progressive oogenesis in workers it will only take place if they are released from the repressor effect of queen pheromone [51].

Different from the oocyte, which enter meiosis and remains transcriptionally silent, nurse cells undergo a series of endomitotic cycles $[46,52]$. This characteristic, typical of the meroistic ovary, is an evolutionary strategy to increase the synthesis of material and organelles at a high rate during oogenesis, and export them to the growing oocyte through the ring canals $[53,54]$. During oogenesis of the honey bee, the somatic follicle cells become a thick epithelium around the growing oocyte and a flattened cell layer around the joined nurse cells [55]. To account for the intense oocyte growth during oogenesis and vitellogenesis, the follicle cells that surround the oocyte must undergo several rounds of mitotic divisions. Unpublished data from our laboratory (Macedo LMF, personal communication) documented the significant increase in follicle cell number in the growing follicles of the honey bee. Consistent with a role in DNA replication, HEX 70a was localized in the polyploid nuclei of nurse cells and in the proliferating follicle cells covering the growing follicle in queen ovarioles. The pattern of HEX 70a foci in the nucleus, however, is distinct for nurse and follicle cells, perchance reflecting their respective physiological status. HEX 70a was also localized in the terminal filament cells where mitotically active BrdU labeled nuclei, probably stem germline cell nuclei, were demonstrated by Tanaka and Hartfelder 

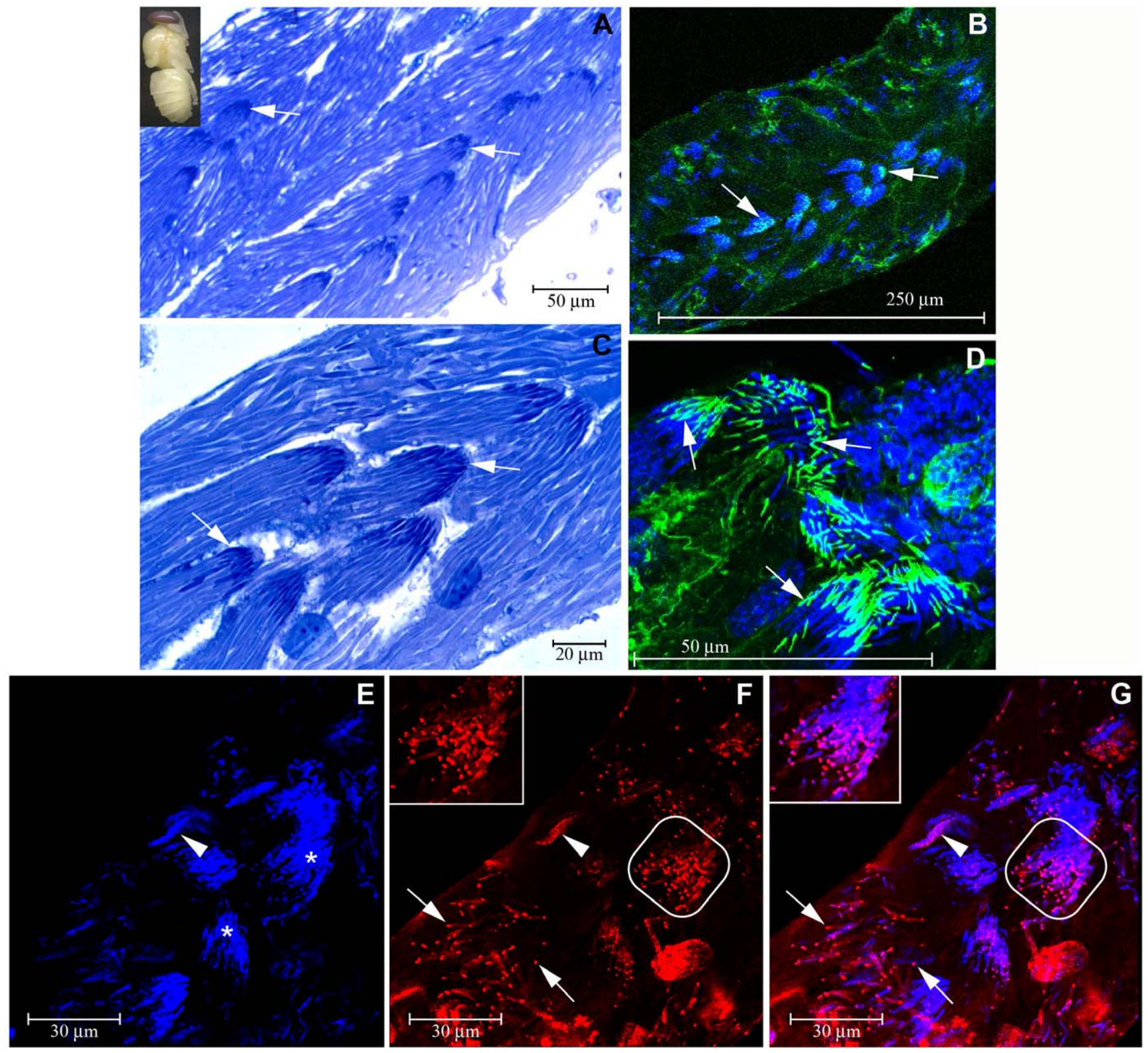

Figure 6. Immunolocalization of HEX 70a in the testioles of pharate-adult drones ( 6 days after pupal ecdysis; developmental stage shown at the upper left corner). (A, C) Light microscopy of the testiole stained with methylene blue/basic fuchsin. Syncytial cluster of spermatids are evident (arrows). (B, D) Confocal microscopy images showing rhodamine/phaloidin labeled F-actin (green) and DAPI-labeled cell nuclei (blue). The association of actin with spermatid heads in the syncytial clusters is evidenced in B (arrows) and in the similar and amplified D image (arrows). (E-G) Confocal microscopy showing (E) DAPI-stained nuclei in the syncytial cluster of spermatids (asterisks) and in a cyst somatic cell nuclei (arrowhead); (F) HEX 70a foci detected with anti-HEX 70a/Cy3 (red) at the posterior end of the spermatid nuclei in the syncytial cluster (shown in higher magnification at the upper left side): arrows point to individualized spermatozoa and the arrowhead points to a cyst somatic cell nuclei. (G) The merged E-F images showing the amplified syncytial cluster of spermatids (insert), individualized spermatozoa (arrows) and a cyst somatic cell nuclei (arrowhead).

doi:10.1371/journal.pone.0029006.g006

(2004) [42]. Interestingly, only in this ovariole region we were able to distinguish HEX 70a foci in the cytoplasm in addition to the nuclear focal spots. We were unable to localize HEX 70a in the nuclei of meiotic oocytes.

Intranuclear foci of HEX 70a were also detected in the germ and somatic cells of the male gonad during its early and late development. Unambiguous cytoplasmic foci of HEX 70a were observed only in the earlier stages of testis development and in the terminal filament of the ovarioles. As spermatogenesis and oogenesis progresses the foci of HEX 70a become exclusively intranuclear.

In newly-ecdysed drone pupae, the clusters of dividing secondary spermatogonia, also termed cystocytes, become enveloped by actin-rich somatic cells and in the interior of these cyst capsules they develop in spermatocytes, which then initiate the meiotic division $[52,56]$. Within the cyst, the germ cells remain connected by cytoplasmic bridges, the ring canals, similar to what is seen in the ovarioles. Thus, the presence of HEX 70a in the 
male cystocyte and somatic nuclei may also be tentatively associated to cell proliferation. However, as discussed below, HEX 70a was in addition detected in the nucleus of the nonproliferating spermatids and individualized spermatozoa.

In the honey bee drone, the entire process of spermatogenesis, from the undifferentiated male germ cell to the formation of the motile sperm occurs during postembryonic development and is essentially concluded before emergence of the drone from the brood cell. The spermatozoa then migrate from the testioles to the seminal vesicles where they are stored for a few days before copulation during the nuptial flight [45]. Spermatogenesis in the honey bee is distinguished by (1) an atypical meiosis (drones are originated from haploid eggs) during which the spermatocytes remain interconnected by cytoplasm bridges, (2) formation and subsequent elimination of supernumerary centrioles in association with the first meiotic division, and (3) unequal division of the secondary spermatocyte [57].

During spermatogenesis in Drosophila melanogaster, a cyst of 64 syncytial spermatids derived from a single germ cell precursor elongates as the axonemes of the sperm tails are formed. These syncytial spermatids become finally separated into individual sperm in a process named individualization, which occurs simultaneously for all 64 spermatids. Actin polymerization is important for individualization, and this process is mediated by cones of actin that assemble around each sperm nucleus. Actin cones acquire triangular shape and move away from the sperm nucleus, causing the formation of the cystic bulge, the residual body which contains cytoplasm and organelles that will be discarded. This process ultimately leads to the transition from syncytial spermatids to individualized spermatozoa [58].

During spermiogenesis of the honey bee, we could detect foci of HEX 70a at the syncytial spermatid nuclei, posteriorly to the assembled actin cones, and also in the nuclei of individualized spermatozoa. The presence of HEX 70a in the nuclei of differentiating spermatids and in the spermatozoa certainly cannot be associated to cell proliferation, but suggests a novel, distinct role for this protein also during the spermiogenesis. This is a completely novel finding concerning a hexamerin function that requires further investigation.

\section{Hexamerins - more than just storage proteins for metamorphosis}

Almost 20 years ago it was demonstrated that fat body tissue or fat body extracts (from lepidopteran species) were efficient in stimulating in vitro proliferation of larval midgut stem cells of some lepidopterans [59-61]. Curiously, the fat body factor that induced cell proliferation was later identified as being a $77 \mathrm{kDa}$ arylphorin subunit ( $\alpha$-arylphorin) [62]. Purified $\alpha$-arylphorin stimulated midgut stem cell proliferation at a very low concentration, which excludes a simple nutritional effect. Experiments using BrdU labeling confirmed that arylphorin induces DNA synthesis. The mitogenic-stimulating activity of arylphorin was also observed in vivo in insects that showed increased growth rates after being fed on artificial diets containing arylphorin [62-64]. Therefore, experimental approaches very distinct from those utilized herein, have led to the same conclusion, i.e., that arylphorins have a role in cell proliferation.

Our results brought to light entirely unsuspected roles for a storage protein. The presence of HEX 70a in the nuclei of germline and somatic cells in ovaries and testes suggests function in regulation, structural nuclear organization and/or cell proliferation. These gonadal functions of a larval storage protein are novelties that clearly deserve further investigation.

\section{Materials and Methods}

\section{Bee sampling}

Africanized honey bee workers and drones in different developmental stages (pupal, pharate-adult and adult) were collected from hives maintained at the apiary of the University of São Paulo in Ribeirão Preto, Brazil. Queens were reared according to standard apicultural methods. Some queens were collected soon after pupal ecdysis and some were collected at emergence and introduced in dequeened hives to be collected later, after mating and the onset of egg laying activity. Pupae and pharate-adults were staged according to the criteria established by Michelette and Soares (1993) [65] (workers), Tozetto et al. (2007) [66] (drones) and Rembold et al. 1980 [67] (queens), which are based on the progress of eye coloration, from white to dark-brown, and absence or presence and grade of exoskeleton tanning. Before dissection, adult bees were anesthetized with gaseous nitrogen.

\section{Conventional light microscopy}

Gonads were dissected and briefly rinsed in Ringer saline $(\mathrm{NaCl}$ $0.17 \mathrm{M}, \mathrm{KCl} 0.01 \mathrm{M}, \mathrm{CaCl}_{2} 0.003 \mathrm{M}$ ) and kept for 24 hours in cold $\left(4^{\circ} \mathrm{C}\right)$ fixative $(4 \%$ paraformaldehyde in $0.1 \mathrm{M}$ phosphate buffer, $\mathrm{pH}$ 7.3), dehydrated in a graded ethanol series and then embedded in methacrylate resin (Historesin, Leica). Sections of $4 \mu \mathrm{m}$ thickness were stained with methylene blue and basic fuchsin and mounted in Entellan (Merck) to be examined and photographed using an Axioskop II photomicroscope (Zeiss).

\section{Confocal microscopy}

F-actin and nuclei staining. After dissection in phosphate buffered saline $\left(\mathrm{PBS}_{1}: 137 \mathrm{mM} \mathrm{NaCl}, 2.7 \mathrm{mM} \mathrm{KCl}, 10 \mathrm{mM}\right.$ $\mathrm{Na}_{2} \mathrm{HPO}_{4}, 1.7 \mathrm{mM} \mathrm{KH} \mathrm{PO}_{4}, \mathrm{pH} 7.4$ ), ovaries and testes were cleaned as much as possible of trachea and immersed in a honey bee-specific tissue culture medium [68] for separating individual ovarioles and testioles and removal of the peritoneal sheath. Ovarioles and testioles were then fixed for $30 \mathrm{~min}$ in $240 \mu \mathrm{L} \mathrm{PBS}_{1}$, $200 \mu \mathrm{L} \mathrm{37 \%} \mathrm{formaldehyde} \mathrm{(Merck),} 8 \mu \mathrm{L}$ Triton X-100 (Sigma) and $2 \mu \mathrm{L}$ rhodamine-phalloidin 1:100 v/v (Invitrogen). After being washed twice in $0.2 \%$ Triton $\mathrm{X}-100$ in $\mathrm{PBS}_{1}(0.2 \% \mathrm{TPBS})$ and $0.1 \%$ rhodamine -phalloidin for $20 \mathrm{~min}$ each, a third $20 \mathrm{~min}-$ wash was done in $0.2 \%$ TPBS without rhodamine -phalloidin. Ovaries and testioles were then incubated for $5 \mathrm{~min}$ in DAPI $\left(4^{\prime}, 6-\right.$ diamidino-2-phenylindole) $1: 8000 \mathrm{v} / \mathrm{v}$ (Sigma) in 0.2\% TPBS and then rinsed five times in $0.2 \%$ TPBS. Slides were mounted in glycerol 80\% (Merck) and examined under a Leica TCS-SP5 confocal microscope (Leica Microsystems).

HEX 70a immunolocalization. A custom-made polyclonal anti-HEX 70a specific antibody (Affinity BioReagents, Golden, $\mathrm{CO}$, USA) was produced from the sequence SYKMHQKPYNKD of the HEX 70a subunit predicted from the fully sequenced cDNA [23]. This antibody was used in whole mount preparations of ovarioles and testioles from bees in different developmental stages. The pre-immune serum was used as negative control.

Ovarioles and testioles were fixed for $20 \mathrm{~min}$ in $4 \%$ paraformaldehyde in $\mathrm{PBS}_{1}$, permeabilized with $0.1 \%$ Triton X-100 in $\mathrm{PBS}_{1}(0.1 \%$ TPBS) for $15 \mathrm{~min}$ (five washes), blocked with $1 \% \mathrm{BSA}$ for $30 \mathrm{~min}$ and incubated in 5\% normal goat serum for $30 \mathrm{~min}$. Ovarioles and testioles were incubated with anti-HEX 70a at a concentration of $1: 50$ in $0.1 \%$ TPBS, $1 \%$ BSA and $5 \%$ normal goat serum for $16 \mathrm{~h}$ at $4{ }^{\circ} \mathrm{C}$. This was followed by five washes of $20 \mathrm{~min}$ in $0.1 \%$ TPBS, blocking with $1 \% \mathrm{BSA}$ for $20 \mathrm{~min}$ (two washes) and incubation in 5\% normal goat serum for $30 \mathrm{~min}$. A Cy3-conjugated goat anti-rabbit antibody (Sigma, 1:200 dilution) was added to the preparations, which were incubated for $2 \mathrm{~h}$ at 
room temperature. Ovaries and testioles were then incubated in DAPI (4',6-diamidino-2-phenylindole) $1: 8000 \mathrm{v} / \mathrm{v}$ (Sigma) in 0.1\% TPBS for $5 \mathrm{~min}$ and then rinsed five times in $0.1 \%$ TPBS. Slides were mounted in glycerol $80 \%$ (Merck) and examined under a Leica TCS-SP5 confocal microscope (Leica Microsystems).

EdU and HEX 70a colocalization. Newly ecdysed worker pupae ( $\mathrm{Pw}$ phase) collected from hives and kept in an incubator at $34^{\circ} \mathrm{C}$ and $80 \%$ relative humidity for $24 \mathrm{~h}$ were injected with $1 \mu \mathrm{l}$ of a $40 \mu \mathrm{M}$ 5-ethynyl-2' deoxyuridine (EdU, Click-iT ${ }^{\mathrm{TM}}$ EdU Imaging Kits - Invitrogen) solution in Ringer saline. The injection was administered into the abdominal hemocoel. After $24 \mathrm{~h}$ the injected bees were dissected for extraction of the ovaries. The ovaries were fixed in $3.7 \%$ formaldehyde in $\mathrm{PBS}_{1}$ for $30 \mathrm{~min}$ and subsequently transferred to the Click-iT ${ }^{\mathrm{TM}}$ EdU Imaging Kits reaction mixture $(43 \mu \mathrm{l} 10 \mathrm{X}$ reaction buffer; $38 \mu \mathrm{l}$ distilled water; $20 \mu \mathrm{l}$ copper sulphate; $1.2 \mu \mathrm{l}$ Alexa Fluor 594; $50 \mu \mathrm{l}$ reaction buffer additive) where they remained for $30 \mathrm{~min}$. The permeabilization and HEX 70a localization were performed as described above.

\section{Effect of anti-HEX 70a on hemolymph levels of HEX 70a and on cuticle sclerotization}

Treatment of workers and queens with anti-HEX

70a. Newly ecdysed queen and worker pupae ( $\mathrm{Pw}$ phase) were collected from hives and maintained in an incubator at $34^{\circ} \mathrm{C}$ and $80 \%$ relative humidity for $24 \mathrm{~h}$ before receiving an injection of $1 \mu \mathrm{l}(1 \mu \mathrm{g})$ of the anti-HEX 70a antibody, diluted in $0.9 \% \mathrm{NaCl}$, into the abdominal hemocoel. Controls received $1 \mu \mathrm{l}$ of $0,9 \%$ $\mathrm{NaCl}$ or $1 \mu \mathrm{l}(1 \mu \mathrm{g})$ of mouse $\mathrm{IgG}\left(\mathrm{ECL}^{\mathrm{TM}}\right.$ Western Blotting Analysis System, Amersham Biosciences) in 0,9\% NaCl. The injected queens and workers, and their respective control groups, were maintained in the incubator until the adult ecdysis. Since HEX 70a is an arylphorin, and as such it may be implicated in cuticle formation, the progress of pigmentation and sclerotization was followed daily until adult ecdysis. Following adult ecdysis of the control worker bees, the hemolymph was collected from both worker groups (control and experimental) for Western blot analysis to attest the levels of free HEX 70a. Queens had their ovarioles dissected soon after adult ecdysis and stained with DAPI for measurement of width.

Western blot. The hemolymph samples from the newly ecdysed adult workers injected with anti-HEX 70a or with saline vehicle only were centrifuged at $2000 \times g$ for $1 \mathrm{~min}$ at $4^{\circ} \mathrm{C}$. Total protein was quantified [69] in the supernatants and samples

\section{References}

1. Telfer WH, Kunkel JG (1991) The function and evolution of insect storage hexamers. Annu Rev Entomol 36: 205-228.

2. Beintema JJ, Stam WT, Hazes B, Smidt MP (1994) Evolution of arthropod hemocyanins and insect storage proteins (hexamerins). Mol Biol Evol 11: 493-503.

3. Burmester T, Scheller K (1999) Ligands and receptors: common theme in insect storage protein transport. Naturwissenschaften 86: 468-474.

4. Levenbook L (1985) Insect storage proteins. In: Kerkut GA, Gilbert LI, eds. Comprehensive Insect Physiology Biochemistry and Pharmacology, Vol 9. New York: Oxford Pergamon Press. pp 307-346.

5. Roberts DB, Brock HW (1981) The major serum proteins of Dipteran larvae. Experientia 37: 103-212.

6. Levenbook L, Bauer AC (1984) The fate of the larval storage protein calliphorin during adult development of Calliphora vicina. Insect Biochem 14: 77-86.

7. Pan ML, Telfer WH (1996) Methionine-rich hexamerin and arylphorin as precursor reservoirs for reproduction and metamorphosis in female luna moths. Arch Insect Biochem Physiol 33: 149-162.

8. Wheeler DE, Tuchinskaya II, Buck NA, Tabashnik BE (2000) Hexameric storage proteinsduring metamorphosis and egg production in the diamondback moth, Plutella xylostella (Lepidoptera). J Insect Physiol 46: 951-958.

9. Pan ML, Telfer WH (2001) Storage hexamer utilization in two lepidopterans: differences correlated with the timing of egg formation. J Insect Sci 1: 1-9. containing $5 \mu \mathrm{g}$ of total protein were used for electrophoresis in denaturing conditions [70] carried out at $15 \mathrm{~mA}$ and $4^{\circ} \mathrm{C}$ using $7.5 \%$ polyacrylamide gels $(100 \times 120 \times 0.9 \mathrm{~mm})$. Following electrophoresis, the proteins were transferred to nitrocellulose membranes (ImmunBlot ${ }^{\text {TM }}$ PVDF Membrane). The membranes were stained with Coomassie Brillant Blue (CBB) to check migration of hemolymph proteins and molecular mass markers (205, 116, 97.4, 66, 45 and $29 \mathrm{kDa}$, Sigma). Non-specific biding sites were blocked by incubating the membranes for $16 \mathrm{~h}$ with $10 \%$ non-fat dried milk in $\mathrm{PBS}_{2}(50 \mathrm{mM}$ Tris, $80 \mathrm{mM} \mathrm{NaCl}$, $2 \mathrm{mM} \mathrm{CaCl}_{2}, \mathrm{pH}$ 8.5). HEX 70a subunits were detected by incubating the membranes for $1 \mathrm{~h}$, at room temperature, with anti-HEX 70a antibody diluted 1:5,000 in 10\% non-fat dried milk in $\mathrm{PBS}_{2}$. The membranes were washed thoroughly in $0.05 \%$ Tween 20 in $\mathrm{PBS}_{1}(0.05 \%$ TwPBS $)$ and subsequently incubated for $1 \mathrm{~h}$ in a horseradish peroxidase labeled anti-rabbit $\mathrm{IgG}$ secondary antibody (Amersham Biosciences), diluted 1:12,000 in $0.05 \%$ TwPBS. After washing in $0.05 \%$ TwPBS, the detection was carried out by using the ECL System $\left(\mathrm{ECL}^{\mathrm{TM}}\right.$ Western Blotting Analysis System, Amersham Biosciences). The constitutively expressed $\sim 200 \mathrm{kDa}$ hemolymph lipophorin identified in the CBB-stained nitrocellulose membranes was used as a loading control.

Measurements of ovary width. Ovaries from HEX 70a antibody-injected queens and from $0.9 \%$ NaCl-injected controls were fixed in $3.7 \%$ formaldehyde in $\mathrm{PBS}_{1}$ during $30 \mathrm{~min}$ and incubated in DAPI (1:400 dilution) in $0.1 \%$ TPBS for $5 \mathrm{~min}$. After rinsing five times in $0.1 \%$ TPBS the ovarioles were mounted in $80 \%$ glycerol for analysis in a Leica TCS-SP5 confocal microscope system. Ovariole width was measured by using the software LAS AF Lite 2.4.1 (Leica Microsystems).

\section{Acknowledgments}

The authors thank Luiz Roberto Aguiar for expert assistance in the apiary, Dr. Ricardo G. Ramos to facilitate access to confocal microscope, and Dr. Klaus Hartfelder for critically reading a previous version of the manuscript. We also thank two anonymous reviewers for their comments that improved the manuscript.

\section{Author Contributions}

Conceived and designed the experiments: JRM MMGB. Performed the experiments: JRM LA RPD. Analyzed the data: JRM MMGB. Contributed reagents/materials/analysis tools: MMGB ZLPS. Wrote the paper: JRM MMGB. Edited the manuscript: JRM MMGB RPD ZLPS.

10. Telfer WH, Pan ML (2003) Storage hexamer utilization in Manduca sexta. J Insect Sci 3: 26.

11. Baker HG, Baker I (1973) Amino-acids in nectar and their evolutionary significance. Nature 241: 543-545.

12. Wheeler DE, Buck NA (1996) A role for storage proteins in autogenous reproduction in Aedes atropalpus. J Insect Physiol 42: 961-966.

13. Zakharkin SO, Headley VV, Kumar NK, Buck NA, Wheeler DE, et al. (2001) Female specific expression of a hexamerin gene in larvae of an autogenous mosquito. Eur J Biochem 268: 5713-5722.

14. Jamroz RC, Beintema JJ, Stam WT, Bradfield JY (1996) Aromatic hexamerin subunit from adult female cockroaches (Blaberus discoidalis): molecular cloning, suppression by juvenile hormone, and evolutionary perspectives. J Insect Physiol 42: $115-124$.

15. Capurro M deL, Marinotti O, Farah CS, James AA, Bianchi AG (1997) The nonvitellogenic female protein of Musca domestica is an adult-specific hexamerin. Insect Mol Biol 6: 97-104.

16. Hahn DA, Wheeler DE (2003) Presence of a single abundant storage hexamerin in both larvae and adults of the grasshopper, Schistocerca americana. J Insect Physiol 49: 1189-1197.

17. Martinez T, Wheeler DE (1993) Identification of two storage hexamers in the ant, Camponotus festinatus: accumulation in adult queen-less workers. Insect Biochem Mol Biol 23: 309-317. 
18. Martinez T, Wheeler DE (1994) Storage proteins in adult ants (Camponotus festinatus): roles in colony founding by queens and in larval rearing by workers. J Insect Physiol 40: 723-729.

19. Johnston ML, Wheeler DE (2007) The role of storage proteins in colony founding in termites. Insect Soc 54: 383-387.

20. Ditzel N, Andersen SO, Højrup P (2003) Cuticular proteins from the horseshoe crab, Limulus polyphemus. Comp Biochem Physiol Part B 134: 489-497.

21. Konig M, Agrawal OP, Schenkel H, Scheller K (1986) Incorporation of calliphorin into the cuticle of developing blowfly, Calliphora vicina. Roux's Arch Dev Biol 195: 296-301.

22. Ancsin JB, Wyatt GR (1990) Purification and characterization of two hemolymph proteins from Locusta migratoria. In: Hagedorn HH, Hildebrand JG, Kidwell MG, Law JH, eds. Mol Insect Sci Plenum Press, New York. pp 275-276.

23. Martins JR, Nunes FMF, Simões ZLP, Bitondi MMG (2008) A honeybee storage protein gene, hex $70 a$, expressed in developing gonads and nutritionally regulated in adult fat body. J Insect Physiol 54: 867-877.

24. Munn EA, Feinstein A, Greville GD (1967) A major protein constituent of pupal of the blowfly Calliphora erythrocephala. Biochem J 102: 5-6.

25. Webb B, Riddiford LM (1988) Synthesis of two storage proteins during larval development of the tobacco hornworm, Manduca sexta. Dev Biol 130: 671-681.

26. Wu M, Tischler ME (1995) Utilization of $\left[{ }^{14} \mathrm{C}\right]$ phenylalanine derived from arylphorin or free amino acid in Manduca sexta pharate adults. Arch Insect Biochem Physiol 28: 257-272.

27. Pan ML, Telfer WH (1999) Equivalence of riboflavin-binding hexamerin and arylphorin as reserves for adult development in two saturniid moths. Arch Insect Biochem Physiol 42: 138-146.

28. Koopmanschap AB, deKort CAD (1988) Isolation and characterization of a high molecular weight JH-III transport protein in the hemolymph of Locusta migratoria. Arch Insect Biochem Physiol 7: 105-118.

29. Braun RP, Wyatt GR (1996) Sequence of the hexameric juvenile hormonebinding protein from the hemolymph of Locusta migratoria. J Biol Chem 271: 31756-31762.

30. Ismail SM, Gillott C (1995) Identification, characterization, and developmental profile of a high molecular weight, juvenile hormone binding protein in the hemolymph of the migratory grasshopper, Melanoplus sanguinipes. Arch Insect Biochem Physiol 29: 415-430.

31. Zalewska M, Kochman A, Estève JP, Lopez F, Chaoui K, et al. (2009) Juvenile hormone binding protein traffic - interaction with ATP synthase and lipid transfer proteins. BBA Biomembranes 1788: 1695-1705.

32. Zhou X, Oi FM, Scharf ME (2006) Social exploitation of hexamerin, RNAi reveals a major caste-regulatory factor in termites. Proc Natl Acad Sci USA 103: $4499-4504$.

33. Zhou X, Tarver MR, Bennett GW, Oi FM, Scharf ME (2006) Two hexamerin genes from the termite Reticulitermes flavipes, sequence, expression, and proposed functions in caste regulation. Gene 376: 47-58.

34. Zhou X, Tarver MR, Scharf ME (2007) Hexamerin-based regulation of juvenile hormone dependent gene expression underlies phenotypic plasticity in a social insect. Development 134: 601-610.

35. Scharf ME, Buckspan CE, Grzymala TL, Zhou X (2007) Regulation of polyphenic caste differentiation in the termite Reticulitermes flavipes by interaction of intrinsic and extrinsic factors. J Exp Biol 210: 4390-4398.

36. Martins JR, Nunes FMF, Gristino AS, Simões ZLP, Bitondi MMG (2010) The four hexamerin genes in the honey bee: structure, molecular evolution and function deduced from expression patterns in queens, workers and drones. BMC Mol Biol 11: 23

37. Hunt JH, Kensinger BJ, Kossuth JA, Henshaw MT, Norberg K, et al. (2007) Diapauses pathway underlies the gyne phenotype in Polistes wasps, revealing an evolutionary route to caste-containing insect societies. Proc Natl Acad Sci USA 104: $14020-14025$

38. Ryan RO, Schmidt JO, Law JH (1984) Arylphorin from the hemolymph of the larval honeybee. Insect Biochem 14: 515-520.

39. Danty E, Arnold G, Burmester T, Huet JC, Huet D, et al. (1998) Identification and developmental profiles of hexamerins in antenna and hemolymph of the honeybee, Apis mellifera. Insect Biochem Mol Biol 28: 387-397.

40. Cunha AD, Nascimento AM, Guidugli KR, Simões ZL, Bitondi MM (2005) Molecular cloning and expression of a hexamerin cDNA from the honeybee, Apis mellifera. J Insect Physiol 51: 1135-1147.

41. Bitondi MM, Nascimento AM, Cunha AD, Guidugli KR, Nunes FM, et al. (2006) Characterization and expression of the Hex 110 gene encoding a glutamine-rich hexamerin in the honeybee, Apis mellifera. Arch Insect Biochem Physiol 63: 57-72

42. Tanaka ED, Hartfelder K (2004) The initial stages of oogenesis and their relation to differential fertility in the honey bee (Apis mellifera) castes. Arthropod Struct Dev 33: 431-442.
43. Kamakura M (2011) Royalactin induces queen differentiation in honeybees. Nature 473: 478-483.

44. Bateman A, Coin L, Durbin R, Finn RD, Hollich V, et al. (2004) The Pfam protein families database. Nucleic Acid Res 32: D138-141.

45. Snodgrass RE (1956) Anatomy of the Honey Bee. New York: Comstock Publ Assoc Cornell Univ Press Ithaca.

46. Büning J (1994) The Insect Ovary. Ultrastructure, previtellogenic growth and evolution. London: Chapman \& Hall.

47. Lin H, Yue L, Spradling AC (1994) The Drosophila fusome, a germline-specific organelle, contains membrane skeletal proteins and functions in cyst formation. Development 120: 947-956.

48. Gutzeit HO, Zissler D, Fleig R (1993) Oogenesis in the honeybee Apis mellifera: cytological observations on the formation and differentiation of previtellogenic ovarian follicles. Roux's Arch Dev Biol 202: 181-191.

49. Schmidt Capella IC, Hartfelder K (2002) Juvenile-hormone-dependent interaction of actin and spectrin is crucial for polymorphic differentiation of the larval honey bee ovary. Cell Tissue Res 307: 265-272.

50. Wilson MJ, Abbott H, Dearden PK (2011) The evolution of oocyte patterning in insects: multiple cell-signaling pathways are active during honeybee oogenesis and are likely to play a role in axis patterning. Evol Dev 13: 127-137.

51. Page RE, Erickson EH (1988) Reproduction by worker honey bees (Apis mellifera L). Behav Ecol Sociobiol 23: 117-126.

52. Cruz-Landim C (2009) Aparelho reprodutor feminino e ovogênese. In: Abelhas Morfologia e Função de Sistemas, Chapter 1. São Paulo: Editora Unesp. pp $15-57$.

53. Engels W (1968) Extraoocytäre Komponenten des Eiwachstums bei Apis mellifica. I. Trophocytäre RNS-Zufuhr. Insect Soc 15: 271-288.

54. Spradling AC (1993) Developmental genetics of oogenesis. In: Bate M, Martinez-Arias A, eds. Drosophila Development. New York: Cold Spring Harbor Press. pp $1-70$.

55. Fleig R, Gutzeit HO, Engels W (1991) Structural organization of ovarian follicle cells in the cotton bug (Dysdercus intermedius) and the honey bee (Apis mellifera). Cell Tissue Res 265: 297-305.

56. Louveaux J (1977) Anatomie de l'abeille: X- L'appareil reproducteur du male. Bull Tech Apic 4: 43-48.

57. Hoage TR, Kessel RG (1968) An electron microscope study of the process of differentiation during spermatogenesis in the drone honey bee (Apis mellifera L.), with special reference to centriole replication and elimination. J Ultrastruct Res 24: 6-32.

58. Noguchi T, Miller KG (2003) A role for actin dynamics in individualization during spermatogenesis in Drosophila melanogaster. Development 130: 1805-1816.

59. Loeb MJ, Hakim RS (1996) Insect midgut epithelium in vitro: an insect stem cell system. J Insect Physiol 42: 1103-1111.

60. Sadrud-Din SY, Hakim RS, Loeb M (1994) Proliferation and differentiation of midgut epithelial cells from Manduca sexta, in vitro. Invert Reprod Dev 26: 197-204.

61. Sadrud-Din SY, Loeb MJ, Hakim RS (1996) In vitro differentiation of isolated stem cells from the midgut of Manduca sexta larvae. J Exp Biol 199: 319-325.

62. Blackburn MB, Loeb MJ, Clark E, Jaffe H (2004) Stimulation of midgut stem cell proliferation by Manduca sexta $\alpha$-arylphorin. Arch Insect Biochem Physiol 55: 26-32.

63. Hakim RS, Blackburn MB, Corti P, Gelman DB, Goodman C, et al. (2007) Growth and mitogenic effects of arylphorin in vivo and in vitro. Arch Insect Biochem Physiol 64: 63-73.

64. Cermenati G, Corti P, Caccia S, Giordana B, Casartelli M (2007) A morphological and functional characterization of Bombyx mori larval midgut cells in culture. Invert Suv J 4: 119-126.

65. Michelette ERF, Soares AEE (1993) Characterization of preimaginal developmental stages in Africanized honeybee workers (Apis mellifera L.). Apidologie 24: 431-440.

66. Tozetto SO, Bitondi MMG, Dallacqua RP, Simões ZLP (2007) Protein profiles of testes, seminal vesicles and accessory glands of honeybee pupae and their relation to the ecdysteroid titer. Apidologie 38: 1-11.

67. Rembold H, Kremer JP, Ulrich GM (1980) Characterization of postembryonic developmental stages of the female castes of the honeybee, Apis mellifera L. Apidologie 11: 29-38.

68. Rachinsky A, Hartfelder K (1998) In vitro biosynthesis of juvenile hormone in larval honey bees: comparison of six media. In Vitro Cell Dev Biol Anim 34: 646-648.

69. Bradford MM (1976) A rapid and sensitive method for the quantification of microgram quantities of protein utilizing the principle of protein-dye binding. Anal Biochem 72: 248-254.

70. Laemmli UK (1970) Cleavage of structural proteins during assembly of the head of bacteriophage T4. Nature 227: 680-682. 
Article

\section{7}

\title{
Nuclear immunolocalization of hexamerins in the fat body of metamorphosing honey bees
}

\author{
Juliana Ramos Martins ${ }^{1}$, Márcia Maria Gentile Bitondi ${ }^{2, *}$ \\ 1 Departamento de Genética, Faculdade de Medicina de Ribeirão Preto, Universidade de São Paulo, \\ Ribeirão Preto, SP, Brasil; E-Mails: julianarmartins@usp.br \\ 2 Departamento de Biologia, Faculdade de Filosofia, Ciências e Letras de Ribeirão Preto, \\ Universidade de São Paulo, Ribeirão Preto, SP, Brasil; E-Mails: mmgbit@usp.br \\ * Author to whom correspondence should be addressed; E-Mail: mmgbit@usp.br; \\ Tel.: +55-016-3602-3805; Fax: +55-016-3633-0069.
}

Received: / Accepted: / Published:

Abstract: Hexamerins are storage proteins with primordial functions in insect metamorphosis. They are actively secreted by the larval fat body and stored in the hemolymph. During metamorphosis they return to the fat body to be processed. For decades, these proteins were thought to exclusively function as an amino acid source for tissue reconstruction during the non-feeding pupal and pharate adult stages and, in some species, for egg production. Recently, new findings have linked the hexamerins to caste polyphenism and gonad development in social insects. To explore the roles of hexamerins during the honey bee metamorphosis, we used specific antibodies in expression analysis by western blot, in situ immunolocalization by confocal laser-scanning microscopy, and in vivo injections to lower their endogenous levels. Our expression analysis highlighted the changing expression patterns in the fat body and hemolymph during development, which is consistent with the temporal dynamics of hexamerin secretion, storage and depletion. Confocal microscopy showed hexamerin expression in the cytoplasm of both types of fat body cells, trophocytes and oenocytes. Notably, hexamerin foci were also found in the nuclei of these cells, thus confirming our western blot analysis of fat body nuclear-enriched fractions. We also observed that the decrease in soluble hexamerins in antibody-treated pharate adults led to a precocious adult ecdysis, perhaps in response to the lack (or decrease) in hexamerin-derived amino acids. Taken together, these findings indicate that hexamerins have other functions in addition to their well-established role as amino acids sources for development. 
Keywords: hexamerin; HEX 70a; HEX 70b; HEX 70c; HEX 110; fat body; metamorphosis; honeybee; Apis mellifera

\section{Introduction}

The fat body is an abundant tissue in the insect abdomen where it is localized subjacent to the epidermis (parietal fat body) and around the gut (visceral fat body). It is also found in association with the gonads, muscles and regions outside the abdomen [1]. The trophocyte, the basic fat body cell type, the oenocyte, another important cell, and other less common cells in some insect species, such as the urocytes and mycetocytes, have long been identified as the structural components of the fat body [2]. The fat body is bathed in the hemolymph, which is important for optimizing the secretion and uptake of molecules in spite of the basal lamina that interfaces between the tissue and the circulating fluid [2].

The fat body has a primordial role in the intermediary metabolism. During the larval stage, it is actively engaged in the metabolism of lipids and carbohydrates and in the synthesis and secretion of proteins, which are stored in large quantities in the hemolymph [1;3]. Hemolymph storage proteins were first identified by Munn et al. [4-6] and Munn and Greville [7] in Calliphora. Wyatt and Pan [8] later identified these proteins in the hemolymph of several insects, thus confirming their general occurrence. The storage proteins have also been referred to as larval serum proteins in the literature. Some storage proteins have even been named according to the insect genus where they were identified, for example, calliphorin (from Calliphora), manducin (from Manduca) and others [9; 10]. The name hexamerins, which has been privileged, refers to their hexameric structure.

The diverse amino acid compositions of the hexamerins have been used to classify them. For example, arylphorins are named for their high content of aromatic amino acids; there are also methionine-rich hexamerins and other types [10]. Phylogenetically, the hexamerins belong to the hemocyanin family, although they have lost the ability to bind and transport oxygen [11].

The hexamerins are mainly synthesized by the larval fat body and are secreted in the hemolymph. In general, the titer of these proteins in the hemolymph is highest at the end of the larval feeding stage, but the titer then progressively decreases, due to their uptake by the fat body during and after metamorphosis. Munn and Greville [7] originally proposed that the hexamerins are the protein reserves in the fat body during the development of the post-metamorphic non-feeding stages (pupae and pharate adults). In Calpodes [12] and in Hyalophora cecropia [13], hexamerins form membranebound protein storage granules in the fat body cell cytoplasm. Storage proteins were also isolated from the fat body of Bombyx mori [14], presumably from protein granules, and the uptake of hemolymph proteins into fat body granules was demonstrated in Drosophila [15].

Hexamerins may have other functions in addition to being storage proteins. In grasshoppers, they may play a role as hemolymph juvenile hormone transporters [16-18]. It was also demonstrated that hexamerins interact with other proteins in a multiprotein complex engaged in sequestration and transport of juvenile hormone, thus regulating its levels and actions [19], including the action on caste determination in social insects. In the termite Reticulitermes flavipes, a hexamerin has been associated to the regulation of the juvenile hormone-dependent soldier caste phenotype [20-23]. 
To our knowledge, Ryan et al. [24] were the first to characterize a hexamerin in the honey bee. They identified a $74 \mathrm{kDa}$ hexamerin subunit in the larval hemolymph using an antiserum against a $M$. sexta arylphorin. Years later, Danty et al. [25] analyzed the expression of the $74 \mathrm{kDa}$ hexamerin subunit and the other three hexamerin subunits of the honey bee. The respective N-termini were sequenced, and they were named HEX 70a, HEX 70b, HEX 70c and HEX 110, corresponding to the approximate molecular mass determined by SDS-PAGE migration. Our laboratory further characterized the cDNAs encoding all four hexamerin subunits, their transcriptional profiles in the developing fat body, their regulation by morphogenetic hormones, and their expression dependent on nutritional intake. We also looked for potential regulatory motifs shared by the four hexamerin genes in the 5' upstream control regions, which could indicate that they are co-regulated [26-29]. In addition, we investigated the expression of the honey bee hexamerins outside the fat body. Interestingly, transcripts for HEX 110, HEX 70a and HEX 70b were detected by qRT-PCR in the developing female and male gonads [29]. Furthermore, the presence of HEX 70a was confirmed in the developing ovaries and testes by antibody staining and confocal microscopy. Surprisingly, foci of HEX 70a were found not only in the cytoplasm of the gonadal germ and somatic cells but also in their nuclei [30]. These results indicated that at least in the gonads, the hexamerins have alternative roles. The presence of foci of HEX 70a in the nuclei of gonadal cells prompted us to look for the localization of hexamerins in the fat body cells. We also compared the temporal dynamics of hexamerins expression in the fat body and hemolymph. In hopes of highlighting the importance of hexamerins in honey bee post-metamorphic development, we lowered their levels in pharate adults and examined the survival and the timing of adult ecdysis.

\section{Experimental section}

\subsection{Bee sampling}

Honey bee workers (Apis mellifera, Africanized) in different developmental stages (5th instar larvae, pharate pupae, pupae and pharate adults) and adults (newly-emerged, nurses and foragers) were collected from hives maintained at the apiary of the University of São Paulo in Ribeirão Preto, SP, Brazil.

\subsection{Sample preparation for SDS-PAGE and western blot}

Hemolymph was collected from the 5th instar larvae in the feeding (L5F) and spinning (L5S) phases, pharate pupae (PP), pupae (white-eyed/unpigmented cuticle, Pw phase), pharate adults at the $\mathrm{Pb}$ phase (brown-eyed/unpigmented cuticle) and $\mathrm{Pbm}$ phase (brown-eyed/intermediarily pigmented cuticle), newly ecdysed adults $(\mathrm{Ne})$, nurse bees $(\mathrm{Nu})$ and forager bees (Fo). Hemolymph from individual bees in each developmental phase was collected from a small lateral incision at the abdominal tergites, using microcapillary tubes previously washed in phenylthiourea solution in water. The hemolymph was mixed with protease inhibitors cocktail (Protease Inhibitor Cocktail Tablets Roche Applied Science) at the proportion of 10:1 (v/v), and centrifuged at 2,000 $\mathrm{xg}$ for 1 min at $4^{\circ} \mathrm{C}$. 
118 The supernatants were used for protein separation by SDS-PAGE and hexamerin identification by western blot and reaction with the specific anti-hexamerin antibodies.

The fat body was quickly dissected from the same bees from which the hemolymph was collected, placed in microtubes, frozen in liquid nitrogen, powdered with the aid of a small glass pestle, and centrifuged at $10,000 \times \mathrm{g}$ for $10 \mathrm{~min}$ at $4^{\circ} \mathrm{C}$. The supernatants were used for SDS-PAGE followed by western blot and membrane incubation with each anti-hexamerin antibody.

Nuclear fractions from the fat body of 5th instar larvae at the spinning phase (L5S) were obtained by using a procedure based on Kirankumar et al. [31]. After being dissected in $\mathrm{PBS}_{1}(137 \mathrm{mM}$ $\mathrm{NaCl}, 2.7 \mathrm{mM} \mathrm{KCl}, 10 \mathrm{mM} \mathrm{Na}_{2} \mathrm{HPO}_{4}, 1.7 \mathrm{mM} \mathrm{KH}_{2} \mathrm{PO}_{4}, \mathrm{pH} 7.4$ ), the fat body was rinsed 3 times in $\mathrm{PBS}_{1}$ and gently centrifuged at $250 \mathrm{xg}$ for $15 \mathrm{~min}$ at $4^{\circ} \mathrm{C}$ in $1.5 \mathrm{~mL} \mathrm{PBS}{ }_{1}$ containing $25 \mu \mathrm{L}$ protease inhibitors cocktail. The pellet was resuspended in $1 \mathrm{~mL}$ HEPES buffer (5mM HEPES pH 8.5 containing $0.1 \mathrm{mM} \mathrm{CaCl}_{2}$ and $10 \mu \mathrm{L}$ protease inhibitors cocktail), homogenized by passing through a $13 \times 0.45 \mathrm{~mm}$ Injex ${ }^{\mathrm{TM}}$ needle for 10 times, and centrifuged at $1000 \mathrm{xg}$ for $5 \mathrm{~min}$ at $4^{\circ} \mathrm{C}$. Once again, the pellet was resuspended in $150 \mu \mathrm{L}$ urea/Chaps buffer (8 M urea and $2 \%$ Chaps) containing $2,5 \mu \mathrm{L}$ protease inhibitors cocktail, sonicated (ultrasonic equipment T14, $40 \mathrm{kHz}$, Thorton Eletronica Ltda, Brazil) ( 3 cycles of $5 \mathrm{~min}$ on ice followed by $5 \mathrm{~min}$ under vortex), and centrifuged at $20000 \mathrm{x} g$ for 30 $\min$ at $4{ }^{\circ} \mathrm{C}$. The supernatant served as the source of crude nuclear proteins. Total protein was quantified [32] in the supernatants and samples containing $5 \mu \mathrm{g}$ of total protein were used for SDSPAGE and western blot.

SDS-PAGE [33] was carried out at $15-20 \mathrm{~mA}$ and $4^{\circ} \mathrm{C}$ using $7.5 \%$ polyacrylamide gels measuring $100 \times 120 \times 0.9 \mathrm{~mm}$. Following electrophoresis, the proteins were transferred to nitrocellulose membranes (ImmunBlot ${ }^{\mathrm{TM}}$ PVDF Membrane, Bio-Rad). The membranes were stained with $0.5 \%$ Ponceau in $1 \%$ acetic acid to check the migration of the sample proteins as well as the migration of the molecular mass markers $(205,116,97.4$, 66, 45 and $29 \mathrm{kDa}$, Sigma). Non-specific binding sites were blocked by incubating the membranes for $16 \mathrm{~h}$ in $10 \%$ non-fat dried milk in $\mathrm{PBS}_{2}$ (50 mM Tris, $80 \mathrm{mM} \mathrm{NaCl}, 2 \mathrm{mM} \mathrm{CaCl}$, $\mathrm{pH} 8.5$ ). Hexamerins subunits were detected by incubating the membranes for $1 \mathrm{~h}$, at room temperature, with each hexamerin antibody diluted 1:5000 (HEX 70a) or 1:1000 (HEX 110, HEX 70b and HEX 70c) in 10\% non-fat dried milk in $\mathrm{PBS}_{2}$. The membranes were washed thoroughly in $0.05 \%$ Tween 20 in PBS $_{1}$ (TwPBS) and subsequently incubated for $1 \mathrm{~h}$ in a horseradish peroxidase labeled anti-rabbit IgG secondary antibody (GE Healthcare), diluted 1:12000 in TwPBS. After washing in TwPBS, the detection was carried out by using the ECL System (ECL ${ }^{\mathrm{TM}}$ Western Blotting Analysis System, GE Healthcare).

\subsection{Immunolocalization of the hexamerins in the fat body cells}

Custom-made polyclonal hexamerins specific antibodies (Affinity BioReagents, Golden, USA; Rheabiotech, Brazil) were produced from the sequences NLYTKYHGQYP, SYKMHQKPYNKD, TFNLVENLDNYNDKEAVNEF, RNYDMESNMDMYKDKNVVQK of the HEX 110, HEX 70a, HEX 70b and HEX 70c subunits, respectively, predicted from the fully sequenced cDNAs [20;21]. These antibodies were used in whole mount preparations of the fat body from worker pharate pupae (PP phase) prepared as follows: the fat body was fixed for $20 \mathrm{~min}$ in $4 \%$ paraformaldehyde in $\mathrm{PBS}_{1}$, permeabilized with $0.1 \%$ Triton $\mathrm{X}-100$ in $\mathrm{PBS}_{1}$ for 5 min (three washes), and blocked with $0.6 \%$ 
160 Triton X-100 in $\mathrm{PBS}_{1}$ containing 5\% BSA for 5 min (five washes). This was followed by incubation in 161 this same solution containing 10\% goat serum for $1 \mathrm{~h}$. The fat body was then reincubated with each 162 hexamerin antibody at a concentration of $1: 50$ in $0.6 \%$ Triton X-100 in $\mathrm{PBS}_{1}$ plus 5\% BSA and $10 \%$ 163 goat serum for $16 \mathrm{~h}$ at $4^{\circ} \mathrm{C}$. This was followed by three washes of $5 \mathrm{~min}$ and five washes of $20 \mathrm{~min}$ in $1640.6 \%$ Triton X-100 in $\mathrm{PBS}_{1}$ plus 5\% BSA and subsequent incubation in Alexa Fluor 488 (1:200, 165 Invitrogen) for $2 \mathrm{~h}$ at room temperature. The samples were rinsed again (three washes of $5 \mathrm{~min}$ and five washes of $20 \mathrm{~min}$ in $0.6 \%$ Triton $\mathrm{X}-100$ in $\mathrm{PBS}_{1}$ containing 5\% BSA). To stain the cell nuclei, the fat body was subsequently incubated for $15 \mathrm{~min}$ in $1 \mu \mathrm{g}$ propidium iodide (Invitrogen) diluted in 500 $\mu \mathrm{L}$ of $0.6 \%$ Triton $\mathrm{X}-100$ in $\mathrm{PBS}_{1}$. Propidium iodide is an intercalating molecule that binds DNA and RNA. After rinsing five times in $0.6 \%$ Triton $\mathrm{X}-100$ in $\mathrm{PBS}_{1}$, the fat body was transferred to glass slides, mounted on glycerol 80\% (Merck) and examined under a Leica TCS-SP5 confocal microscope (Leica Microsystems).

\subsection{Injection of antibodies against hexamerins}

Pupae ( $\mathrm{Pw}$ phase) were collected from hives and maintained in an incubator at $34^{\circ} \mathrm{C}$ and $80 \%$ relative humidity for $24 \mathrm{~h}$ before receiving an injection of $1 \mu \mathrm{L}$ of an antibody $(1 \mu \mathrm{g}$ in $0.9 \% \mathrm{NaCl})$ against one of the hexamerins into the abdominal hemocoel. Controls received $1 \mu \mathrm{L}$ of $0.9 \% \mathrm{NaCl}$ or 1 $\mu \mathrm{L}$ of mouse $\operatorname{IgG}(1 \mu \mathrm{g}$ in $0.9 \% \mathrm{NaCl})$. The injection was ministered soon after apolysis when the bees have initiated the pharate adult development (Pp phase). The injected pharate adults were maintained in the incubator, at the same conditions mentioned above, up to the adult ecdysis. The hemolymph or fat body was collected $4 \mathrm{~h}$ and $24 \mathrm{~h}$ after the injection for Western blot analysis to attest the levels of soluble hexamerins. Survival as well as the time elapsed to the adult ecdysis were verified.

\section{Results}

3.1. Dynamics of hexamerin expression in the hemolymph and fat body during and after metamorphosis

We verified the expression of the four hexamerins in the hemolymph and fat body during precise developmental time points by western blotting (Figure 1). In $5^{\text {th }}$ instar feeding larvae (L5F), all hexamerins exist in a larger quantity in the hemolymph than in the fat body, indicating intense secretion to the hemolymph. During the next developmental phase when the $5^{\text {th }}$ instar spinning larvae (L5S) prepare for the metamorphic molt, the abundance of all hexamerins increases in the fat body. Based on what is known about the exchange of hexamerins between the fat body and hemolymph, this increase may denote the resorption of hexamerins into the fat body, via sequestration from the hemolymph. From the L5S time point to the pharate adult phases $(\mathrm{Pb}, \mathrm{Pbm})$, the hexamerins still remain relatively abundant in the fat body, although HEX 110 is the least abundant. The abundance of all hexamerins in the fat body decreases to basal levels near the time of adult ecdysis, i.e., at the end of the last pharate adult phase, Pbd (not shown in Figure 1). However, HEX 70a levels increase again in the adults, where this protein persists, even in foragers. The persistence of HEX 70a in the hemolymph of adult workers was first demonstrated by Coomassie Blue stained SDS-PAGE [25]. Since HEX 70a 
200 comigrates with the small lipophorin subunit (ApoLp-II) [34], we used the specific antibody to verify 201 and confirm its persistence in adults [28]. This result was reinforced by the detection of HEX 70a 202 transcripts in adult workers, from the emergence up to 30 days of the adult life [28, 29].

203 The depletion rate of HEX 70b, HEX 70c and HEX 110 in the hemolymph is variable; HEX $20470 \mathrm{~b}$ is depleted earlier. The depletion of hexamerins is consistent with their function as amino acid 205 sources for pupal and pharate adult development. 
Figure 1. Western blot analysis of the four hexamerins (HEX 110, HEX 70a, HEX 70b and HEX 70c) in the hemolymph and fat body of developing Apis mellifera workers. L5F and L5S: feeding and spinning $5^{\text {th }}$ instar larvae. PP: pharate pupae. Pw: pupae. $\mathrm{Pb}, \mathrm{Pbm}$ : successive phases of pharate adults. NE: newly ecdysed adults. Nu: nurse bees. Fo: forager bees. The western blots showing HEX 70a in the fat body and in the hemolymph of pharate adults ( $\mathrm{Pb}$ and $\mathrm{Pbm}$ phases) and adults ( 3 days old $\mathrm{Nu}$ and 24 days old $\mathrm{Fo}$ ) were shown previously (see Fig. 2 in [28].

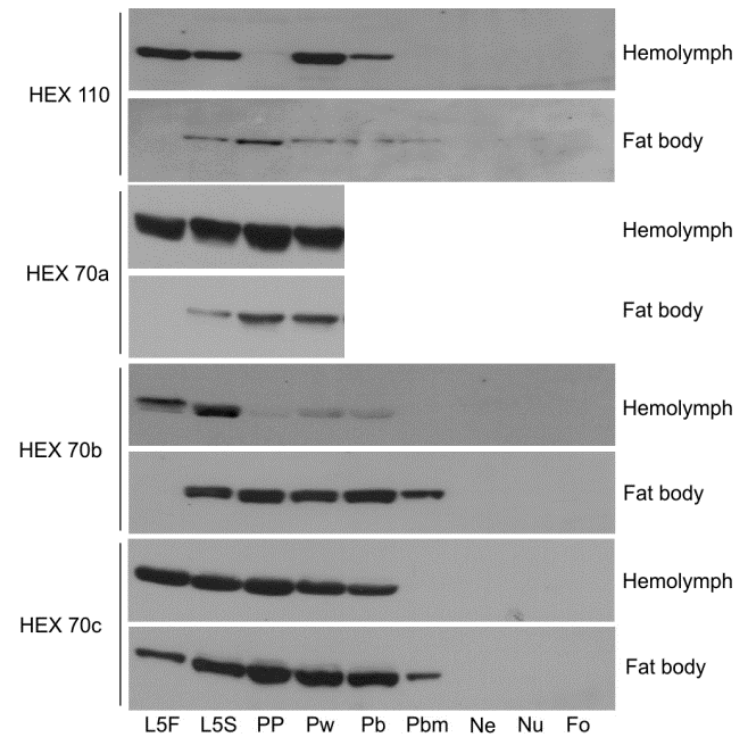

3.2. Detection of hexamerins in isolated fat body cell nuclei

All hexamerins were detected in the nuclear fraction obtained from the fat body, as demonstrated by SDS-PAGE and western blot analysis using specific antibodies (Figure 2). 
Figure 2. Hexamerins detected by western blot analysis in isolated fat body nuclei.

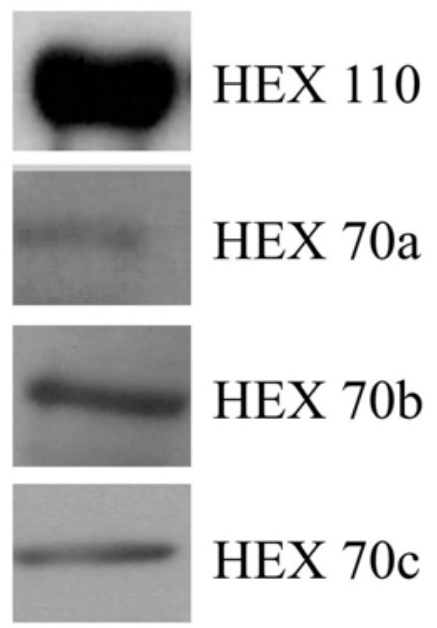

\subsection{Immunolocalization of hexamerins in the cytoplasm and nucleus of fat body cells}

We detected foci of all the honey bee hexamerins in the trophocytes (Figure 3) and oenocytes (Figure 4) in the fat body of pharate pupae (PP) by antibody staining and confocal microscopy. Preparations without the specific (primary) antibodies in Figures 4A-C are the "controls" of the immunolocalization procedures shown in Figures 3 and 4.

In the trophocytes, foci of HEX 110 (Figure 3A-C), HEX 70a (Figure 3D-F), HEX 70b (Figure 3G-I) and HEX 70c (Figure 3J-L) were evident in the nucleus and in the cytoplasm. The nuclear foci of HEX 110 (Figure 3A, C) and HEX 70a (Figure 3D, F) were more evident than the nuclear foci of HEX 70b (Figure 3G, I) and much more evident than the nuclear foci of HEX 70c (Figure 3J, L). The cytoplasmic foci of all four hexamerins were visualized as dense granules of different sizes or as large cytoplasmic inclusions, similar to the protein granules (heterophagic vacuoles) formed by fusing vesicles containing hemolymph proteins described by a previous study [12]. In the trophocytes shown in Figure 3G, we could see HEX 70b foci regularly localized at the cell surface. Hemolymph proteins have been described to concentrate at the cell surface before endocytosis occurs inside vesicles, which subsequently are separated from the cell membrane to form protein granules [12]. Interestingly, the trophocytes incubated with anti-HEX 70b (Figure 3G) and anti-HEX 70c (Figure 3J) show large granules of different densities near the cell surface, which suggests that they were derived from endocytosis of these hexamerins.

A profusion of red inclusions were revealed in the cytoplasm of the trophocytes stained with propidium iodide (see Figures 3B, E, K and the respective merged images 3C, F, L). Propidium iodide is a dye commonly used to visualize nuclear DNA, but it also binds to RNA. The red inclusions in the trophocyte cytoplasm apparently are autophagic vacuoles containing DNA and ribosomal RNA products remnants of mitochondria and RER recycling. At the time of protein granule formation in the pre-metamorphic fat body of Calpodes ethlius, cell organelles are isolated by membranes in 
251 autophagic vacuoles. RER-specific autophagic vacuoles may fuse with heterophagic vacuoles containing sequestered hemolymph proteins that form protein/RNA granules $[12 ; 35 ; 36]$. Similar to in C. ethlius [35], the red inclusions in the trophocyte cytoplasm (Figure 3B, E, H, K) are also characterized by the presence of an uncolored central region that matches the crystalline material in the center of the granules containing proteins and ribosomal RNA.

Hexamerins were also localized in the oenocytes (Figure 4A-O). The oenocytes prepared without the specific (primary) antibodies in Figures 4A-C are the 'controls' of the immunolocalization procedure. The patterns of immunolocalization of HEX 110 (Figure 4D-F) and HEX 70a (Figure 4G-I) are similar, with evident foci of both proteins in the nuclei and smaller scattered foci in the cytoplasm.

260 The other two hexamerins, HEX 70b (Figure 4J-L) and HEX 70c (Figure 4 M-O), were localized 261 exclusively in the oenocyte cytoplasm, and HEX 70c is limited to the peripheral cytoplasm.

Figure 3. Confocal microscopy for detection of hexamerins in the trophocytes of pharate pupae (PP phase). Alexa Fluor 488-stained trophocytes: preparations with (A) anti-HEX 110, (D) anti-HEX 70a, (G) anti-HEX 70b and (J) anti-HEX 70c for detection of the respective hexamerins (green foci). (B, E, H, K) Propidium iodide-stained cell nuclei (red). At the right column the merged images show: (C) HEX 110, (F) HEX 70a, (I) HEX 70b and (L) HEX 70c in the nuclei (yellow foci) and in the cytoplasm (green foci). Large hollowed arrowheads: nuclear foci of hexamerins. Small arrowheads: hexamerins in small granules near the cell surface. Large hollowed arrows: hexamerins in large cytoplasm granules. Small arrows: hexamerins in small cytoplasm granules. The cell in the center of Figures $\mathrm{J}, \mathrm{K}$ and $\mathrm{L}$ is an oenocyte. The profusion of red inclusions in the trophocyte cytoplasm (B, E, K) are propidium iodide stained nucleic acids (DNA/ribosomal RNA), apparently derived from remnants of mitochondria and RER sequestered in autophagic vacuoles. 


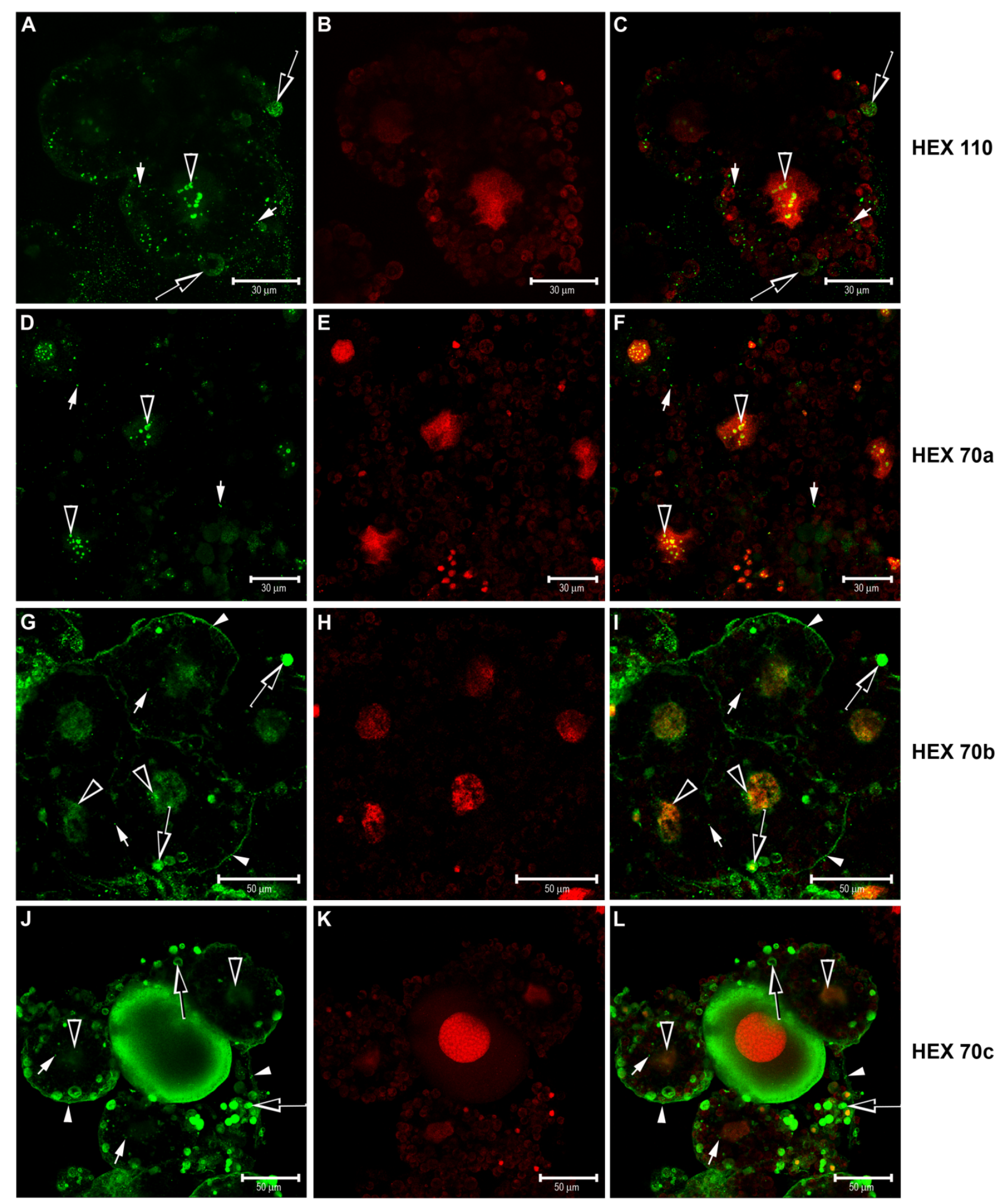


Figure 4. Confocal microscopy for detection of hexamerins in the fat body oenocytes of pharate pupae (PP phase). Alexa Fluor 488-stained enocytes: preparations (A) without the specific (primary) antibody (control) or with (D) anti-HEX 110, (G) anti-HEX 70a, (J) anti-HEX 70b or (M) anti-HEX 70c for detection of the respective hexamerins (green foci). (B, E, H, K, N) Propidium iodide-stained cell nuclei (red). At the right column the merged images show: (C) the control without the antibody, (F) HEX 110 and (I) HEX 70a mainly in the nuclei (yellow foci) but also in the cytoplasm (green foci), (L) HEX 70b in the cytoplasm (green foci), (O) HEX 70c at the cytoplasmic periphery (green foci). Arrowheads: nuclear foci of hexamerins. Arrows: hexamerin foci in the cytoplasm. 


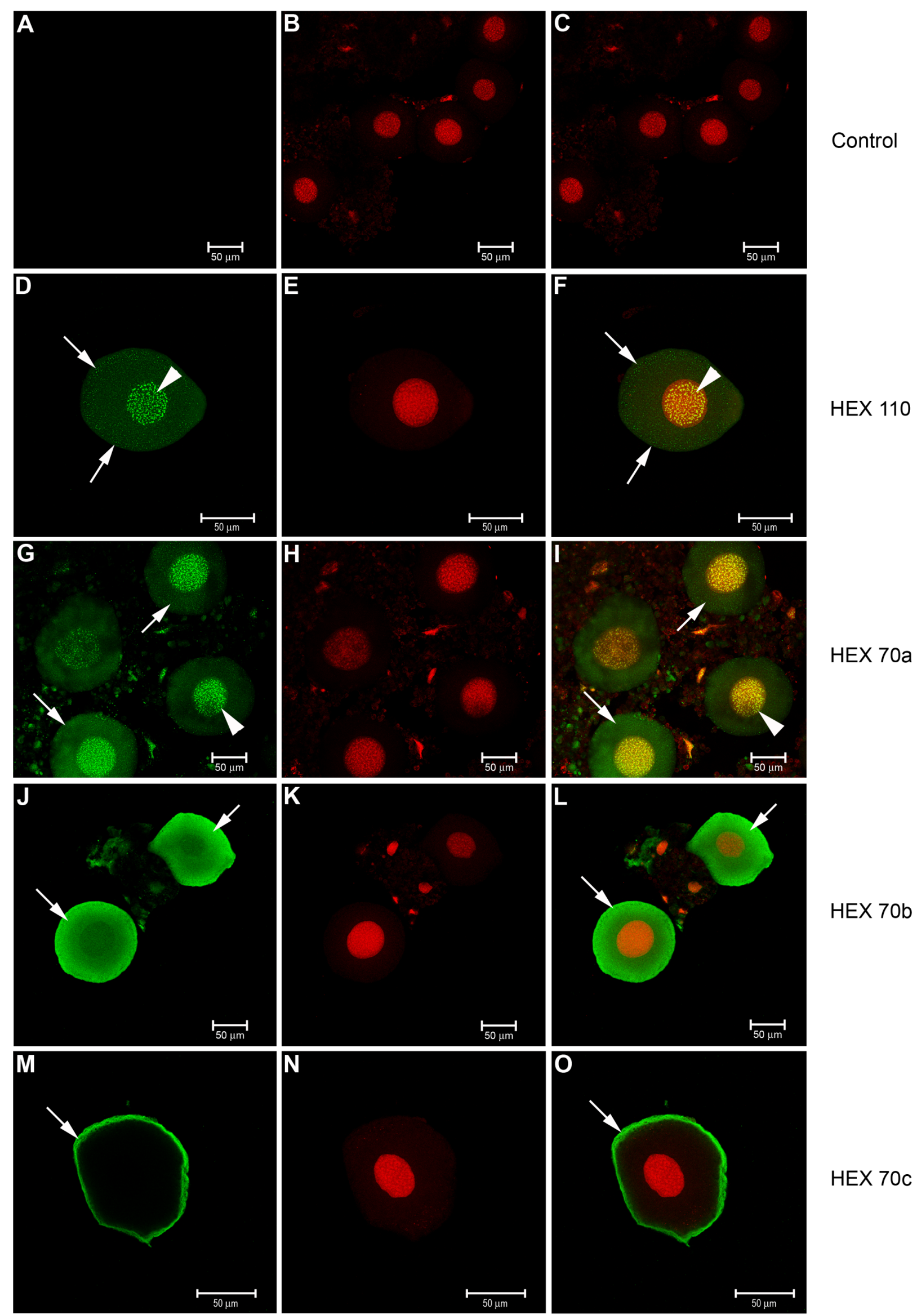


288 3.4. Injection of antibodies against hexamerins in pharate adults: effect on survival and timing to adult 289 ecdysis

The injection of each antibody against the hexamerins resulted in decreased levels of these proteins 292 as shown by western blot analysis of the hemolymph or fat body (Figure 5A). At the $24 \mathrm{~h}$ postinjection time point, the bees were at the beginning of the $\mathrm{Pb}$ pharate adult phase. At this stage, HEX 294110 decreases in the hemolymph and the levels of HEX 70c will fall somewhat later (before the Pbm 295 phase) (see Figure 1). HEX 70a remains high as previously demonstrated (see Fig. 2 in [28]). We 296 verified that $4 \mathrm{~h}$ after the injection of anti-HEX 110 or anti-HEX 70a, the levels of the respective 297 hexamerins decreased in the hemolymph. However, normal levels of HEX 70a were recovered $24 \mathrm{~h}$ after the injection. A decrease in the hemolymph levels of HEX 70c was observed $24 \mathrm{~h}$ after the 299 injection (Figure 5A). Because the level of HEX 70b is normally very low in the hemolymph during the $\mathrm{Pb}$ phase (see Figure 1) and thus impairs the analysis of the effect of anti-HEX 70b, we used the fat 301 body, where the level of this hexamerin is still high (see Figure 1), in the western blot analysis shown 302 in Figure 5A. This figure illustrates that the injection of the antibody caused HEX 70b depletion in the 303 fat body.

304 The injections did not significantly affect survival $(\mathrm{p}=0.524)$ up to adult ecdysis (Figure 5B), but 305 the bees injected with the antibodies against hexamerins underwent adult ecdysis significantly earlier 306 than the controls injected with $0.9 \% \mathrm{NaCl}$ or anti-mouse $(\mathrm{p}=0.019)$ (Figure 5C). 
Figure 5. Effect of the injection of anti-hexamerins in pharate adults. (A) Western blots showing depletion of HEX 110, HEX 70a and HEX 70c in the hemolymph, and depletion of HEX 70b in the fat body of pharate adults, 4 and $24 \mathrm{~h}$ after injection with $1 \mu \mathrm{g}$ of the respective antibodies diluted in $0.9 \% \mathrm{NaCl}$. Control groups were injected with $0.9 \% \mathrm{NaCl}$ or with $1 \mu \mathrm{g}$ of anti-mouse in $0.9 \% \mathrm{NaCl}$. The western blot showing the effect of antiHEX 70a on HEX 70a depletion was previously shown (see Fig. 4 in [30]). (B) All the bee groups (each containing 22 bees) showed similar survival rates, regardless of antihexamerin injection $(\mathrm{p}=0.524)$. (C) The injected and control groups significantly differed in the time elapsed to the adult ecdysis $(p=0.019)$. Data were analyzed using KaplanMeier survival analysis: Log-Rank followed by multiple comparison procedures $\left(\chi^{2}\right.$ test) (R statistical software, version 2.15.0) . 
A

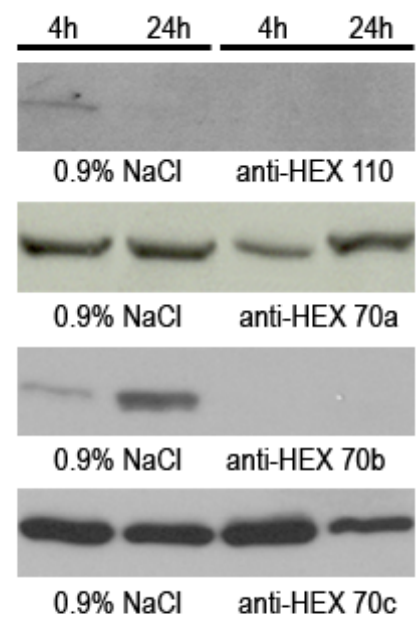

C
B

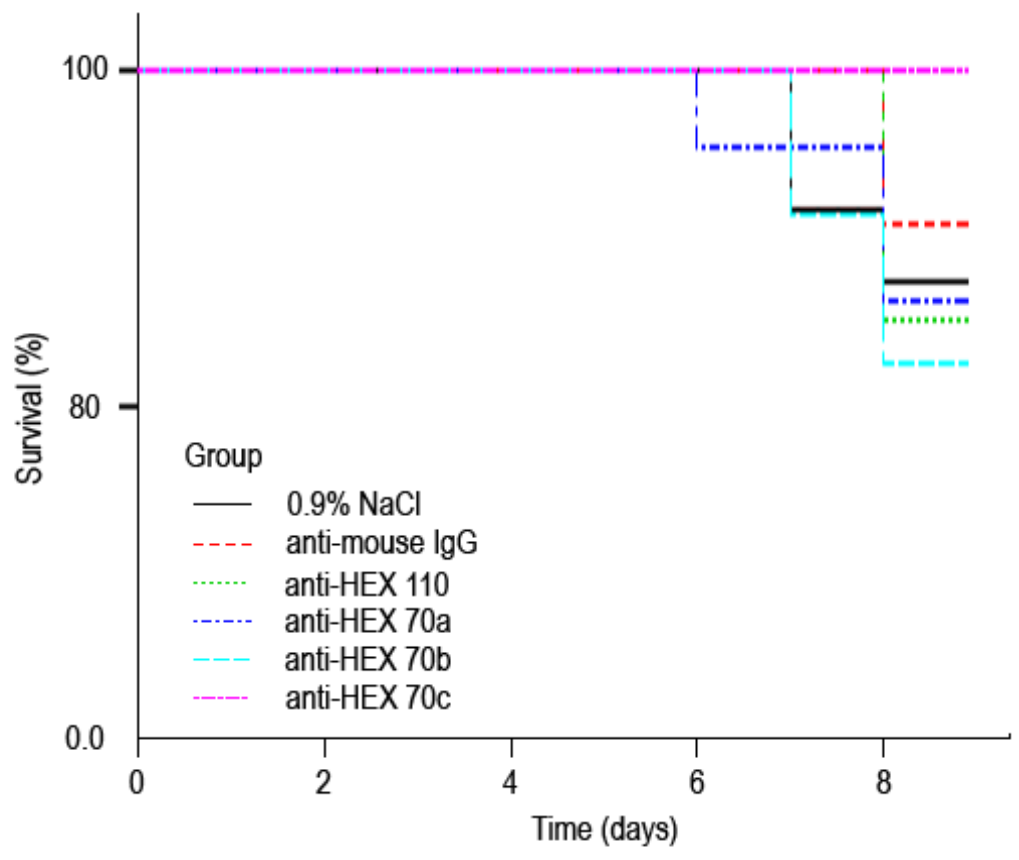

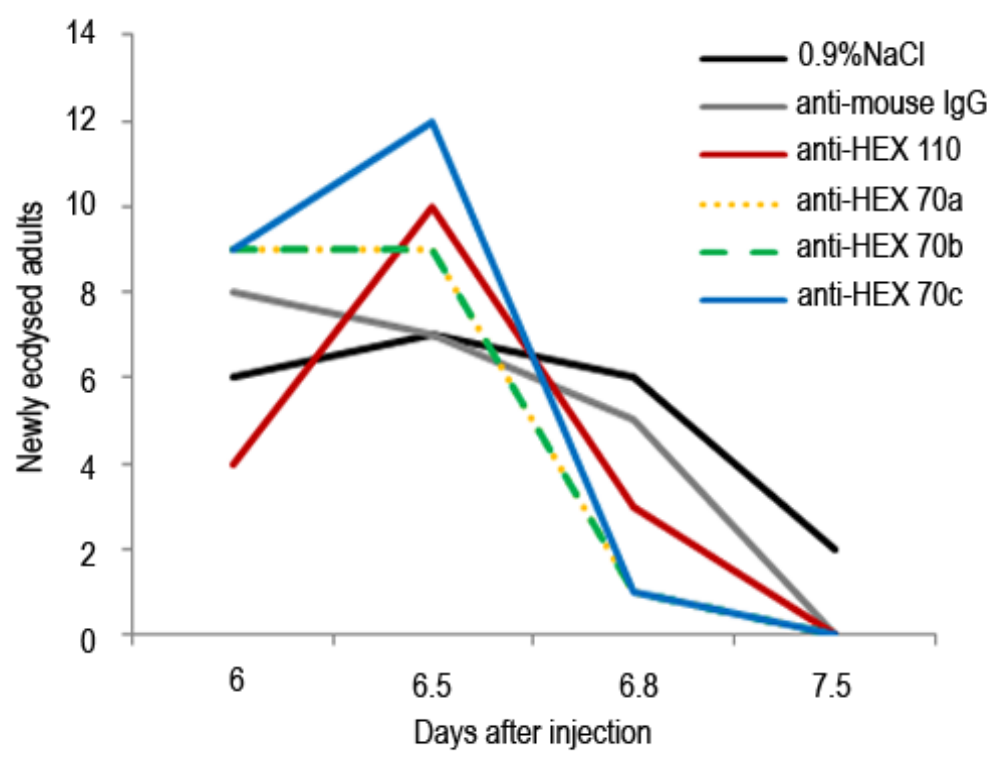

\section{Discussion and Conclusions}

During the metamorphic molt in holometabolous insects, the fat body changes its typical larval architecture, made of layers or clumps of cells, to dissociated individual cells that lose their adhesion to each other [37]. The fat body cells are mostly free in the hemolymph of the honey bee at the pharate pupae stage [38; 39]. At the following pupal and early pharate adult stages, there is a switch from synthesis and secretion of hexamerins, to their sequestration. Studies establishing the correlation between the depletion of hexamerins from the hemolymph and the appearance of granules in the trophocyte cytoplasm predicted that the sequestered hexamerins are stored in these granules for further utilization [12; 13]. This dynamic swap was apparent when we compared the levels of HEX 70b in the hemolymph and fat body of metamorphosing honey bees. There was a progressive decrease of HEX $70 \mathrm{~b}$ in the hemolymph of pharate pupae (PP phase), pupae ( $\mathrm{Pw}$ phase) and early pharate adults $(\mathrm{Pb}$ 
332 phase) as it increased in the fat body (see Figure 1). HEX 70c also showed a similar dynamic, although 333 not as distinctly. The HEX 110 behavior was somewhat different because we could not see a clear 334 increase of this hexamerin in the fat body. Like the majority of the hexamerins, HEX 70b, HEX 70c and HEX 110 are essentially 'metamorphosis proteins', as such, their abundance lowers to basal levels at adult ecdysis. However, as reported previously [25; 28], HEX 70a persists even in adults (see Figure

337 1). Based on the contrasting expression profiles of the fat body and hemolymph, HEX $70 \mathrm{~b}$ may be considered as the most stereotypical hexamerin in the honey bee.

Hexamerin foci were detected in small and large spheroid inclusions, similar to protein granules of different sizes, in the cytoplasm of the trophocytes from pharate pupae. The appearance of protein granules in the fat body of A. mellifera shortly before pupation was reported decades ago by

342 Bishop [40; 41]. Using schematic illustrations, Snodgrass [38] referred to the localization of these granules in the periphery of the trophocyte cytoplasm in the honey bee pharate pupae and also commented that the number of these protein granules continues to increase during the early part of the pupal stage and then disappears near the time of adult ecdysis. Poiani and Cruz-Landim [42] also found large amounts of protein granules in the trophocytes from pharate pupae. The spheroid inclusions, or granules, stained with anti-HEX 70c and with anti-HEX 70b in the trophocytes were mainly localized at the cytoplasmic periphery (see Figure $3 \mathrm{G}, \mathrm{I}, \mathrm{J}, \mathrm{L}$ ), similar to the protein granules described by Snodgrass [38]. Apparently, the observed granules are involved in the storage and recycling of HEX 70b and HEX 70c. Granules stained with anti-HEX 110 and anti-HEX 70a were less abundant in the trophocytes, but this may be due to fat body regionalization. In D. melanogaster, the rate of protein granule formation differs among regions of the fat body [43]. Because we used dissociated fat body from pharate pupae whole body, the trophocytes shown in Figure 3 may come from different regions. Small protein granules are initially formed in the trophocytes and grow by fusing with other granules [12]. It is then possible that the fusion of protein granules is just starting in the trophocytes shown in Figures 3A (stained with anti-HEX 110) and 3D (stained with anti-HEX 70a).

The presence of hexamerins in the cytoplasm of the trophocytes was expected, but we also found small foci of hexamerins in the oenocyte cytoplasm. Oenocytes differ from trophocytes in embryological origin, morphology, and biochemical and physiological functions; they are required for lipid processing, larval growth, the production of pheromone and developmental signaling [37; 44]. Because storage proteins were up to now described in the trophocytes, which are the cells that accumulate proteins in granules and cell inclusions, it was surprising to find hexamerins in the oenocytes. Even more remarkable was, however, to detect the four hexamerins in the nuclei of the trophocytes and HEX 110 and HEX 70a in the nuclei of the oenocytes.

The immunolocalization of the hexamerins in the fat body cell nuclei confirmed the western blot results (Figure 2), which revealed the presence of the four hexamerins in fat body nuclearenriched fractions.

Previously, our laboratory showed that HEX 70a is localized in the nuclei of ovarian and testis cells, which implied a novel role for this hexamerin in the gonads. The nuclear colocalization of HEX 70a with the cell cycle S-phase marker EdU further indicated that HEX 70a may play a role in DNA replication for cell proliferation or polyploidization [30]. This hypothesis is supported by previous experiments demonstrating that a fat body hexamerin (a $77 \mathrm{kDa}$ arylphorin subunit) in lepidopterans 
374 was efficient in stimulating the in vitro proliferation of larval midgut stem cells. Furthermore, 375 experiments using BrdU labeling confirmed that arylphorin induces DNA synthesis and has mitogenic376 stimulating activity in vivo [45-50].

377 However, in contrast to the honey bee ovarian cystocytes, which are mitotically active as 378 shown by BrdU (5-bromo-29deoxy-uridine) labeling [51] and also by EdU labeling [30], the 379 trophocytes in the pharate pupae fat body are not engaged in cell division, but rather in cell 380 dissociation for metamorphosis. Therefore, the function of hexamerins in the fat body nucleus of 381 pharate pupae is certainly not related to cell proliferation. Interestingly, a storage protein (SP2) from 382 the hemolymph of Bombyx mori, which shows $25-30 \%$ similarity with the honey bee hexamerins, 383 suppressed nuclear fragmentation and apoptotic body formation in HeLa cell cultures [52]. This 384 intriguing result may indicate that at the pharate pupae stage, the hexamerins protect the fat body cells 385 from cell death during metamorphosis.

This dual function, regulation of cell proliferation and protection against apoptosis, has been demonstrated for a protein kinase, CK2, which has long been linked to cell proliferation, but which also acts as an anti-apoptotic protein in cancer cells [53]. CK2 inactivates proteins involved in promoting apoptosis, and has been associated to cell survival through the regulation of the function of proteins with roles in transcription, cell signaling, cell-cycle control and DNA repair [54, 55]. The same way it was inferred for hexamerins, CK2 translocates from the cell cytoplasm to the nucleus. Putative substrates for CK2 in the nucleus may include growth factors and non-histone proteins, including transcript factors; chromatin as well as the nuclear matrix should be the preferential targets for CK2 association in the nucleus [53].

Our previous data [30] strongly suggested a function of hexamerins in gonadal cell proliferation. The current data allow us to suggest a complementary role of nuclear hexamerins in protecting fat body cells from cell death during the metamorphic transition. It is noteworthy that few trophocytes in our histological preparations were labeled with anti-HEX/Alexa fluor, being the enocytes labeled more frequently. Labeled cells may be those that were preserved from apoptosis.

Supporting our data indicating the presence of hexamerins in cell nucleus, Begna et al. [56] also detected HEX 110 in the nuclear proteome of worker and queen honey bee larvae in the 4th and 5th instars by using nuclear protein enrichment, two-dimensional electrophoresis and mass spectrometry.

Here, we have also shown that the injection of each antibody at the working concentration of 1 $\mu \mathrm{g}$ in the hemocoele of early pharate adults caused partial or total depletion of hexamerins $4 \mathrm{~h}$ and/or $24 \mathrm{~h}$ post-injection. Depletion of hexamerins did not result in significant mortality in comparison to the control groups. However, the timing of pharate adult development and the ecdysis to the adult stage were significantly accelerated. By cross-reacting with hexamerins and hence inactivating them, the injected antibodies may have disturbed the utilization of these proteins for pharate adult development.

410 Interestingly, a precocious ecdyse was observed independently of the type of the injected anti411 hexamerin antibody. In spite of the differences in the effectiveness of the knockdowns, resulting in 412 total or partial depletion of the hexamerins, or even depletion followed by recovery to normal levels, 413 all the anti-hexamerin-treated bees ecdysed earlier than the controls. Though consistent, this result is 414 difficult to explain, and the complexity increases even more when it is considered that in the 415 hemolymph, the subunits may combine to form a heteromeric hexamerin. If so, by cross-reacting with 
416 the specific subunit in the heteromer, the antibody indirectly also precipitates non-specific subunits. 417 This would tentatively explain the similar effect of injection of each specific antibody on ecdysis 418 timing. In this context, further studies on the interaction of the subunits and structural organization of 419 hexamerins are relevant.

While pupae and pharate adults do not feed, their development is supported by the endogenous stocks of nutrients accumulated during the larval stage. Hexamerins are the main storage proteins in the larval hemolymph and the main source of amino acids for pupal and pharate-adult development. Functioning as nutritional sensors, the natural depletion of hexamerins may play a critical role in signalizing the onset of adult ecdysis. It is possible that the decrease in soluble hexamerins in antibody-treated pharate adults induced a precocious adult ecdysis in response to the lack (or decrease) in hexamerin-derived amino acids.

It is known that metamorphosis in insects is initiated by an as yet largely unknown size-sensing mechanism [57], where the nutritional status of the larvae has an important role in controlling its final size and the onset of the metamorphic molt. Entry into the metamorphic molt depends on a size threshold, or critical weight, at which endocrine events lead to cessation of feeding and onset of metamorphosis [58; 59]. We hypothesize that a nutrient-sensing signal also functions in pharate adults, thus controlling developmental timing to adult ecdysis, which may be disturbed by the depletion of storage proteins. This hypothesis requires further investigations.

Taken together, our results enhance the understanding of the functions of hexamerins. Clearly, the combined use of molecular biology, genetic and biochemical tools are needed to specify the nuclear function of hexamerins in the fat body during insect development.

\section{Acknowledgments}

The authors thank Luiz Roberto Aguiar for expert assistance in the apiary. We also thank Elizabete Rosa Milani by the access to the confocal microscope (FAPESP grants 04/08868-0). Financial support was provided by a grant of the Fundação de Amparo à Pesquisa do Estado de São Paulo to M.M.G.B. (Process no. 2010/16380-9) that also provided a fellowship to J.R.M. (Process no. 442 2008/00541-3).

\section{References and Notes}

1. Keeley, L.L. Physiology and biochemistry of the fat body. In: Comprehensive insect physiology, biochemistry and pharmacology; Kerkut, G.A., Gilbert. L.I., Eds.; Pergamon Press: Oxford, 1985; 3, pp. 211-248.

2. Dean, R.L.; Locke, M.; Collins, J.V. Structure of the fat body. In: Comprehensive insect physiology, biochemistry and pharmacology; Kerkut, G.A., Gilbert, L.I., Eds.; Pergamon Press: Oxford, 1985; 3, pp. 155-210.

3. Arrese, E.L.; Soulages, J.L. Insect Fat body: energy, metabolism and regulation. Annu. Rev. Entomol. 2010, 55, 207-225.

4. Munn, E.A.; Feinstein, A.; Greville, G.D. A major protein constituent of pupae of the blowfly Calliphora erythrocephala (Diptera). Biochem. J. 1967, 102, 5-6. 
5. Munn, E.A.; Price, G.M.; Greville G.D. The synthesis in vitro of the protein calliphorin by fat body from the larva of the blowfly, Calliphora erythrocephala. J. Insect Physiol. 1969, 15, 1601-1605.

6. Munn, E.A.; Feinstein, A.; Greville, G.D. The isolation and properties of the protein calliphorin. Biochem. J. 1971, 124, 367-374.

7. Munn, E.; Greville, G. The soluble proteins of developing Calliphora erythrocephala, particularly calliphorin, and similar proteins in other insects. J. Insect Physiol. 1969, 15, 1935-1950.

8. Wyatt, G.; Pan, M. Insect plasma proteins. Annu. Rev. Biochem. 1978, 47, 779-817.

9. Levenbook, L. Insect storage proteins. In: Comprehensive insect physiology, biochemistry and pharmacology; Kerkut, G.A., Gilbert, L.I., Eds.; Pergamon Press: Oxford, 1985; 9, pp. 307-346.

10. Kanost, M.R.; Kawooya, J.K.; Law, J.H.; Ryan, R.O.; Van Heusden, M.C.; Ziegler, R. Insect hemolymph proteins. Adv. Insect Physiol. 1990, 22, 299- 369.

11. Burmester, T. Origin and evolution of arthropod hemocyanins and related proteins. J. Comp. Physiol. 2002, 172, 95-107.

12. Locke, M.; Collins, J.V. Protein uptake into multivesicular bodies and storage granule in the fat body of an insect. J. Cell Biol. 1968, 36, 453-483.

13. Tojo, S.; Betchaku, T.; Ziccardi, V.; Wyatt, G. Fat body protein granules and storage proteins in the silkmoth, Hyalophora cecropia. J. Cell Biol. 1978, 78, 823-838.

14. Tojo, S.; Nagata, M.; Kobayashi, M. Storage proteins of the silkworm, Bombyx mori. Insect Biochem. 1980, 10, 289-303.

15. Butterworth, F.M.; Tysell, B.; Waclawski, I. The effect of 20-hydroxyecdysone and protein on granule formation in the in vitro cultured fat body of Drosophila. J. Insect Physiol. 1979, 25, 855860.

16. Koopmanschap, A.B.; deKort, C.A.D. Isolation and characterization of a high molecular weight JH-III transport protein in the hemolymph of Locusta migratoria. Arch. Insect Biochem. Physiol. 1988, 7, 105-118.

17. Braun, R.P.; Wyatt, G.R. Sequence of the hexameric juvenile hormone binding protein from the hemolymph of Locusta migratoria. J. Biol. Chem. 1996, 271, 31756-31762.

18. Ismail S.M.; Gillott C. Identification, characterization, and developmental profile of a high molecular weight, juvenile hormone binding protein in the hemolymph of the migratory grasshopper, Melanoplus sanguinipes. Arch. Insect Biochem. Physiol. 1995, 29, 415-430.

19. Zalewska, M.; Kochman, A.; Esteve, J.P.; Lopez, F.; Chaoui, K.; Susini, C.; Ozyhar, A.; Kochman, M. Juvenile hormone binding protein traffic - interaction with ATP synthase and lipid transfer proteins. BBA Biomembranes 2009, 1788, 1695-1705.

20. Zhou, X.; Oi, F.M.; Scharf, M.E. Social exploitation of hexamerin, RNAi reveals a major casteregulatory factor in termites. Proc. Natl. Acad. Sci. USA. 2006, 103, 4499-4504. 
21. Zhou, X.; Tarver, M.R.; Bennett, G.W.; Oi, F.M.; Scharf, M.E. Two hexamerin genes from the termite Reticulitermes flavipes, sequence, expression, and proposed functions in caste regulation. Gene 2006, 376, 47-58.

22. Zhou, X.; Tarver, M.R.; Scharf, M.E. Hexamerin-based regulation of juvenile hormone dependent gene expression underlies phenotypic plasticity in a social insect. Development 2007, 134, 601-610.

23. Scharf, M.E.; Buckspan, C.E.; Grzymala, T.L.; Zhou, X. Regulation of polyphenic caste differentiation in the termite Reticulitermes flavipes by interaction of intrinsic and extrinsic factors. J. Exp. Biol. 2007, 210, 4390-4398.

24. Ryan, R.O.; Schmidt, J.O.; Law, J.H. Arylphorin from the haemolymph of the larval honey bee. Insect Biochem. 1984, 14, 515-520.

25. Danty, E.; Arnold, G.; Burmester, T.; Huet, J.C.; Huet, D.; Pernollet, J.C.; Masson, C. Identification and developmental profiles of hexamerins in antenna and hemolymph of the honeybee, Apis mellifera. Insect Biochem. Mol. Biol. 1998, 28, 387-397.

26. Cunha, A.D.; Nascimento, A.M.; Guidugli, K.R.; Simões, Z.L.P.; Bitondi, M.M.G. Molecular cloning and expression of a hexamerin cDNA from the honey bee, Apis mellifera. J. Insect Physiol. 2005, 51, 1135-1147.

27. Bitondi, M.M.G.; Nascimento, A.M.; Cunha, A.D.; Guidugli, K.R.; Nunes, F.M.F.; Simões, Z.L.P. Characterization and expression of the hex 110 gene encoding a glutamine-rich hexamerin in the honey bee, Apis mellifera. Arch. Insect Biochem. Physiol. 2006, 63, 57-72 .

28. Martins, J.R.; Nunes, F.M.F.; Simões, Z.L.P; Bitondi, M.M.G. A honeybee storage protein gene, hex 70a, expressed in developing gonads and nutritionally regulated in adult fat body. J. Insect Physiol. 2008, 54, 867- 877.

29. Martins, J.R.; Nunes, F.M.F.; Cristino, A.S.; Simões, Z.L.P.; Bitondi, M.M.G. The four hexamerin genes in the honey bee: structure, molecular evolution and function deduced from expression patterns in queens, workers and drones. BMC Mol. Biol. 2010, 11, 23.

30. Martins, J.R.; Anhezini, L.; Dallacqua, R.P.; Simões, Z.L.P.; Bitondi, M.M.G. A honey bee hexamerin, HEX 70a, is likely to play an intranuclear role in developing and mature ovarioles and testioles. PLOS ONE 2011, 6, e29006.

31. Kirankumar, N.; Ismail, S.M.; Dutta-Gupta, A. Uptake of storage protein in the Rice Moth Corcyra cephalonica: Identification of storage protein binding proteins in the fat body cell membranes. Insect Biochem. Mol. Biol. 1997, 27, 671-679.

32. Bradford, M.M. A rapid and sensitive method for the quantification of microgram quantities of protein utilizing the principle of protein-dye binding. Anal. Biochem. 1976, 72, 248-254.

33. Laemmli, U.K. Cleavage of structural proteins during assembly of the head of bacteriophage T4. Nature 1970, 227, 680-682.

34. Robbs, S.L.; Ryan, R.O.; Schmidt, J.O.; Keim, P.S.; Law, J.H. Lipophorin of the larval honeybee, Apis mellifera L. J. Lipid Res. 1985, 26, 241-247. 
561

562

563

564

565

566

567

568

569

570

571

572

573

574

575

576

577

578

579

580

581

582

583

584

585

586

587

588

589

590

591

592

593

594

595

596

597

598

599

600

601

602

603

604

605

606

607

608

609

610

611

36. de Priester, W.; van der Molen, L.G. Premetamorphic changes in the ultrastructure of Calliphora fat cells. Cell Tissue Res. 1979, 198, 79-93.

37. Hoshizaki, D.K. Fat cell development. In: Comprehensive insect physiology, biochemistry and pharmacology; Kerkut, G.A., Gilbert, L.I., Eds.; Elsevier: Oxford, 2005; 2.9, pp. 315-345.

38. Snodgrass, R.E. The fat body, urate cells and oenocytes. In: Anatomy of the honey bee. Cornell University Press: Ithaca, New York, 1956.

39. Cruz-Landim, C. Abelhas - Morfologia e Função de Sistemas. Editora Unesp: São Paulo, 2009, pp. 159-160.

40. Bishop, G.H. Cell metabolism in the insect fat body. I. Cytological changes accompanying growth and histolysis of the fat body of Apis mellifica. J. Morphol. 1922, 36, 567-601.

41. Bishop, G.H. Cell metabolism in the insect fat body. II. A functional interpretation of the changes in structure in the fat body cells of the honey bee. J. Morphol. 1923, 37, 533-553.

42. Poiani, S.B.; Cruz-Landim, C. Storaged products and presence of acid phosphatase in fat body cells at pre-pupal worker stage of Apis mellifera Linnaeus, 1758 (Hymenoptera, Apidae). Micron 2012, 43, 475-478.

43. Tysell, B.; Butterworth, F.M. Different rate of protein granule formation in the larval fat body of Drosophila melanogaster. J. Insect Physiol. 1978, 24, 201-206.

44. Burns, K.A.; Gutzwiller, L.M.; Tomoyasu, Y.; Gebelein, B. Oenocyte development in the red flour beetle Tribolium castaneum. Dev. Gene Evol. 2012, 222, 77-88.

45. Loeb, M.J.; Hakim, R.S. Insect midgut epithelium in vitro: an insect stem cell system. J. Insect Physiol. 1996, 42, 1103-1111.

46. Sadrud-Din, S.Y.; Hakim, R.S.; Loeb, M. Proliferation and differentiation of midgut epithelial cells from Manduca sexta, in vitro. Invert. Reprod. Dev. 1994, 26, 197-204.

47. Sadrud-Din, S.Y.; Loeb, M.J.; Hakim, R.S. In vitro differentiation of isolated stem cells from the midgut of Manduca sexta larvae. J. Exp. Biol. 1996, 199, 319-325.

48. Blackburn, M.B.; Loeb, M.J.; Clark, E.; Jaffe, H. Stimulation of midgut stem cell proliferation by Manduca sexta $\alpha$-arylphorin. Arch. Insect Biochem. Physiol. 2004, 55, 26-32.

49. Hakim, R.S.; Blackburn, M.B.; Corti, P.; Gelman, D.B.; Goodman, C.; Elsen, K.; Loeb, M.J.; Lynn, D.; Soin, T.; Smagghe, G. Growth and mitogenic effects of arylphorin in vivo and in vitro. Arch. Insect Biochem. Physiol. 2007, 64, 63-73.

50. Cermenati, G.; Corti, P.; Caccia, S.; Giordana, B.; Casartelli, M. A morphological and functional characterization of Bombyx mori larval midgut cells in culture. Invert. Suv. J. 2007, 4, 119-126.

51. Tanaka, E.D.; Hartfelder, K. The initial stages of oogenesis and their relation to differential fertility in the honey bee (Apis mellifera) castes. Arthropod Struct. Dev. 2004, 33, 431-442. 
612 613 614 615 616 617 618 619 620 621 622 623 624 625 626 627 628 629 630 631 632 633 634 635 636 637 638 639 640 641 642 643 644 645 646 647 648 649 650 651 652 653 654 655 656 657 658

52. Rhee, W.J.; Lee, E.H.; Park, J.H.; Lee, J.E.; Park, T.H. Inhibition of HeLa Cell apoptosis by storage-protein 2. Biotechnol. Prog. 2007, 23, 1441-1446.

53. Guo, C.; Yu, S.; Davis, A.T.; Wang, H.; Green, J.E.; Ahmed, K. A potential role of nuclear matrixassociated protein kinase CK2 in protection against drug-induced apoptosis in cancer cells. J. Biol. Chem. 2001, 276, 5992-5999.

54. Litchfield, D.W. Protein kinase CK2: structure, regulation and role in cellular decisions of life and death. Biochem. J. 2003, 369, 1-15.

55. Trembley, J.H.; Wang, G.; Unger, G.; Slaton, J; Ahmed, K. Protein kinase CK2 in health and disease: CK2: a key player in cancer biology. Cell Mol. Life Sci. 2009, 66, 1858-1867.

56. Begna, D.; Han, B.; Feng, M.; Fang, Y.; Li, J. Differential expressions of nuclear proteomes between honeybee (Apis mellifera L.) queen and worker larvae: a deep insight into caste pathway decisions. J. Proteome Res. 2012, 11, 1317-1329.

57. Callier, V.; Nijhout, H.F. Control of body size by oxygen supply reveals size-dependent and sizeindependent mechanisms of molting and metamorphosis. Proc. Natl. Acad. Sci. USA 2011, 108, 14664-14669.

58. Davidowitz, G.; D'Amico, L.J.; Nijhout, H.F. Critical weight in the development of insect body size. Evol. Dev. 2003, 5, 188-197.

59. Nijhout, H.F.; Davidowitz, G.; Roff, D.A. A quantitative analysis of the mechanism that controls body size in Manduca sexta. J. Biol. 2006, 5, 16. 